RINALDO ANTONIO RIBEIRO FILHO

\title{
RELAÇÕES TRÓFICAS E LIMNOLÓGICAS NO RESERVATÓRIO DE ITAIPU: UMA ANÁLISE DO IMPACTO DA BIOMASSA PESQUEIRA NAS COMUNIDADES PLANCTÔNICAS
}

\begin{abstract}
Tese apresentada à Escola de Engenharia de São Carlos, Universidade de São Paulo, como parte dos requisitos para obtenção do título de Doutor em Ciências da Engenharia Ambiental.
\end{abstract}

Orientador: Prof. Assoc. Evaldo Luiz Gaeta Espíndola

São Carlos

2006 
AUTORIZO A REPRODUÇÃO E DIVULGAÇÃO TOTAL OU PARCIAL DESTE TRABALHO, POR QUALQUER MEIO CONVENCIONAL OU ELETRÔNICO, PARA FINS DE ESTUDO E PESQUISA, DESDE QUE CITADA A FONTE.

Ficha catalográfica preparada pela Seção de Tratamento da Informação do Serviço de Biblioteca - EESC/USP

Ribeiro Filho, Rinaldo Antonio
R481r Relações tróficas e limnológicas no reservatório de Relações trófílise do impacto da biomassa pesqueira nas comunidades planctônicas / Rinaldo Antonio Ribeiro Filho ; orientador Evaldo Luiz Gaeta Espíndola. -- São Carlos, 2006 .

Tese (Doutorado - Programa de Pós-Graduação e Área de Concentração em Ciências da Engenharia Ambiental) -Escola de Engenharia de São Carlos da Universidade de São Paulo.

1. Cascata trófica. 2. Reservatório. 3. Bottom-up : top-down. 4. Limnologia. 5. Comunidade biótica. 6. Qualidade da água. I. Título. 
Candidato: Engenheiro RINALDO ANTONIO RIBEIRO FILHO

Tese defendida e julgada em 20/11/2006 perante a Comissão Julgadora:
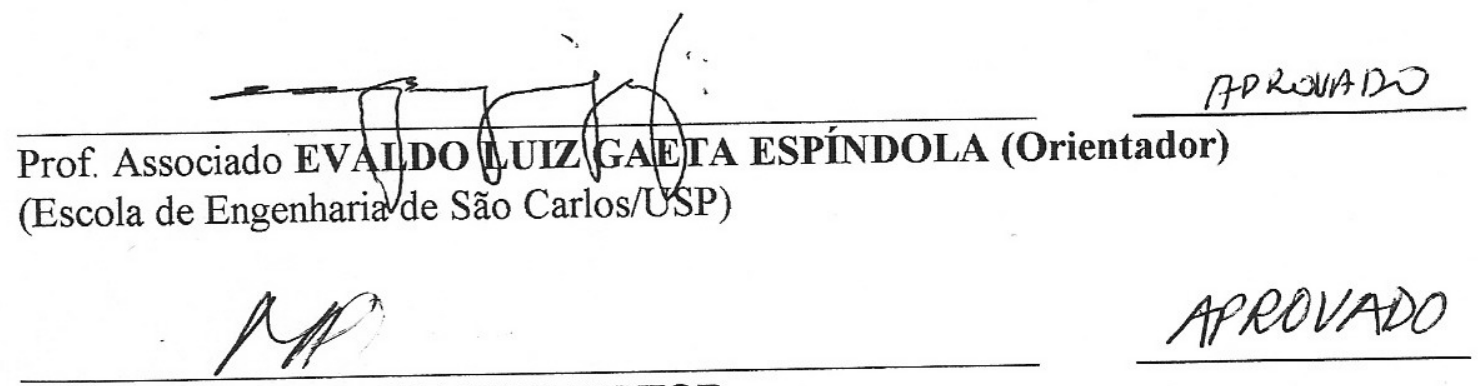

\section{Prof. Dr. MIGUEL PETRERE JUNIOR}

(Universidade Estadual Paulista "Julio de Mesquita Filho"/UNESP-Campus de Rio Claro)

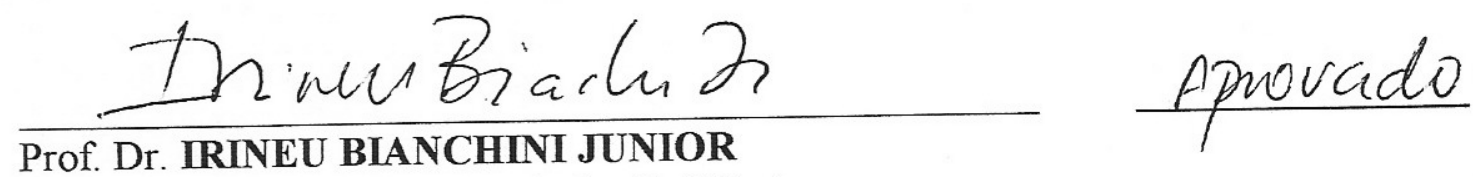

(Universidade Federal de São Carlos/UFSCar)

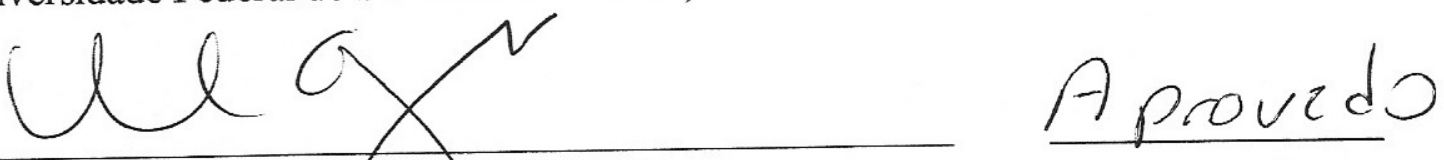

Prof. Dr. MARCOS GOMES NOGUEIRA

(Universidade Estadual Paulista "Jdlio de Mesquita Filho"/UNESP-Campus de Botucatu)

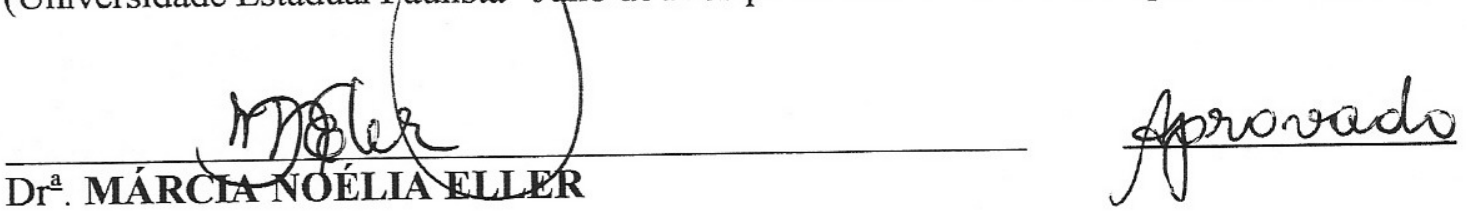

(Pesquisadora/FIPAI)
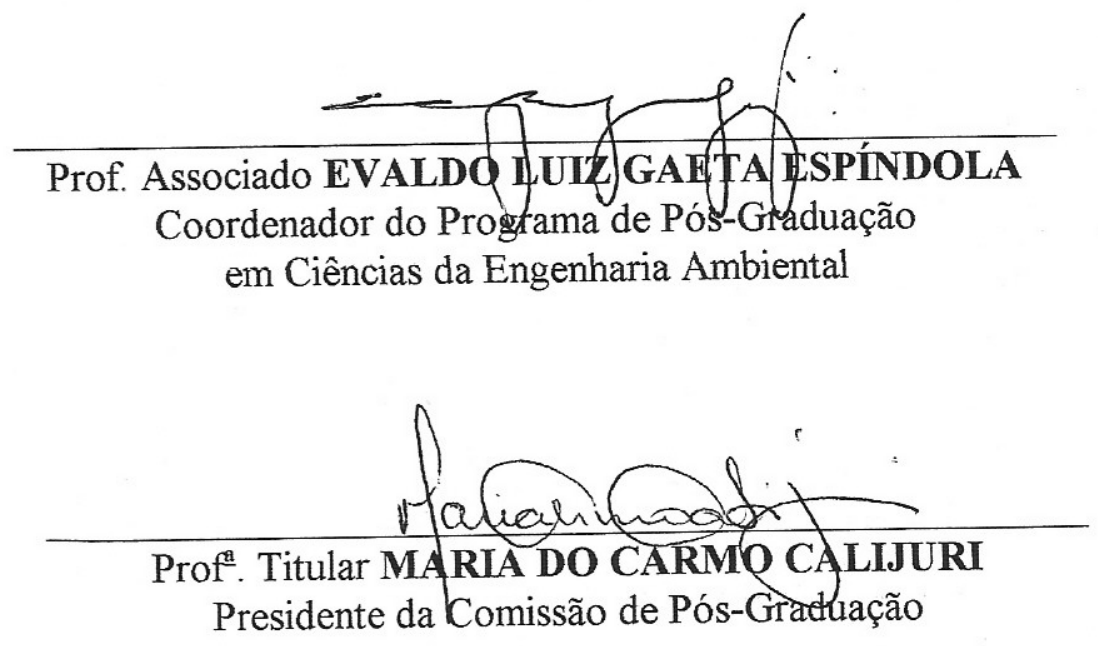
Dedico este trabalho ao amigo e pesquisador Xavier Lazzaro, grande responsável pela minha inserção no estudo de interações tróficas em reservatórios. 


\section{Agradecimentos}

Agradeço a Itaipu Binacional pela disponibilidade dos dados e a seus funcionários MSc. Simone F. Benassi (grande amiga) pela ajuda nos esclarecimentos $e$ fornecimento dos dados de limnologia e relatórios técnicos, ao Eng. Luiz Dalmir Marenda, Dr. Domingo Rodrigues Fernandes e Hélio Martins, pela disponibilização dos dados de peixes, sem os quais seria impossível a elaboração desta Tese de Doutorado.

A Julia, minha querida esposa, por todo amor, carinho, ajuda e paciência durante todo o período de trabalho. Ao meu precioso Diogo, pelo simples fato de sua existência e pelos deliciosos momentos até aqui.

Aos meus pais Rinaldo e Gracita, irmãos Fabiano, Rodrigo e Felipe e toda minha família (avós, tios e primos) que está em Recife. Vocês são duca!

Ao Professor Dr. Evaldo Gaeta Espíndola, pela orientação concedida junto ao Programa de Pós-Graduação em Ciências da Engenharia Ambiental, da Escola de Engenharia de São Carlos, Universidade de São Paulo.

Ao Professor Dr. Miguel Petrere, da Universidade Estadual Paulista, Campus de Rio Claro, pela amizade, valiosas sugestões e oportunidades oferecidas.

Aos amigos de São Carlos: Evandro e Mércia, Caio e Juliana, Ricardo (Cabelo) e Wilminha, Alessandro, Mariana e Zuba, Zá e Alemão.

Aos amigos Paulinho e Betão, por toda ajuda na resolução dos problemas computacionais.

Ao amigo Sebastien pela amizade e bons tempos na UNIOESTE, em Toledo/PR. Ao meu cunhado Marcello Pereira, pela revisão do Abstract.

Aos amigos funcionários do CRHEA: Amândio, Claudete, Mara, Marcelo, Achiles, Regina e Aparecido.

A CAPES, pela concessão de bolsa de estudos. 


\section{RESUMO}

Ribeiro Filho, R.A. Relações tróficas e limnológicas no reservatório de Itaipu: uma análise do impacto da biomassa pesqueira nas comunidades planctônicas. 2006. 70 f. Tese (Doutorado) - Escola de Engenharia de São Carlos, Universidade de São Paulo, São Carlos, 2006.

Inúmeros estudos experimentais contribuíram para o desenvolvimento da teoria das redes tróficas lacustres, revelando o importante papel dos peixes, ignorados no campo da limnologia durante décadas. A maioria dos estudos foi desenvolvida na Europa e Estados Unidos e a generalidade da teoria ainda não foi amplamente testada em ambientes subtropicais e tropicais. Apesar das controversas, as hipóteses de cascata trófica e de bottom-up : top-down são os modelos conceituais mais utilizados. Neste contexto, este trabalho baseia-se na hipótese de que as relações tróficas em cascata, relacionadas aos efeitos bottom-up e top-down, podem ser encontradas no Reservatório de Itaipu, inserido em região subtropical. Com base em dados disponibilizados pela Itaipu Binacional, para o período de 1999 a 2004. Análises de Covariância (ANCOVAs) foram realizadas para determinar as relações das variáveis dependentes clorofila-a, cianobactéria e transparência da água sobre as demais variáveis limnológicas. Análises de correlações também foram realizadas para verificar a existência de algum tipo de efeito na cascata trófica. Os resultados obtidos caracterizam o reservatório como mesotrófico, com situações de oligotrofia na zona lacustre. Efeito negativo foi verificado para transparência da água em relação aos sólidos suspensos totais e turbidez. A clorofila apresentou relação positiva com nitrogênio total, mas não para fósforo total. Os peixes onívoros, detritívoros e insetívoros exerceram efeito negativo (controle) na densidade das cianobactérias e na concentração de clorofila. A estimativa da produção de peixes no reservatório foi melhor relacionada com as cianobactérias do reservatório, gerando um modelo estatístico através desta análise. Os efeitos top-down e bottom-up foram confirmados, sendo que as forças top-down foram encontradas apenas no primeiro nível trófico e as demais apresentaram efeito bottom-up.

Palavras chave: cascata trófica em reservatório, bottom-up : top-down, limnologia, comunidade biótica, qualidade da água. 


\section{ABSTRACT}

Ribeiro Filho, R.A. Trophic and limnological interactions in the Itaipu Reservoir: an analysis of the impact of the fishing biomass in the planktonic communities. 2006. 70 f. Thesis (Doctoral) - Escola de Engenharia de São Carlos, Universidade de São Paulo, São Carlos, 2006.

Many experimental studies contributed for the development of the theory of the lacustrine food web, disclosing the important paper of the fish, for decades ignored by the limnology. These studies, in its majority, had been developed in Europe and North America and the generality of the hypotheses supporting the theory was not tested yet in subtropical and tropical environments. Although controversial, the trophic cascade and bottom-up: top-down hypotheses are the two main conceptual models presently used. This work is based on the hypothesis of the trophic cascade relations, particularly related to bottom-up and top-down effect can be detected in Itaipu Reservoir, a subtropical system. Using the made data available by Itaipu Binacional, from 1999 to 2004. Analyses of Covariance (ANCOVAs) were accomplished to determine the relationships of the dependent variable on the chlorophyll-a, cyanobacterias and transparency of the water (independent variables) and between the other limnologycal variables. Analyses of correlations were also accomplished to verify the existence of some effect type in the trophic cascade. The results show that the reservoir presented mesotrophic, and oligotrophic and characteristics in the lacustrine area. A negative effect was verified between the water transparency in relation to suspended solids and turbid. The chlorophyll presented positive relationship with total nitrogen, but didn't present any relationship with the total phosphorus. The omnivorous, and detritivorous and insectivorous fishes presented a negative effect (control) in the cyanobacteria concentrations and chlorophyll. The estimate of the production of fish in the reservoir was better related with the concentrations of cyanobacterias of the reservoir, generating a statistical model through this analysis. The top-down and bottom-up effect had been confirmed, the forces top-down had been found only in the first trophic level, and the others presented bottom-up effect.

Keywords: trophic cascade reservoir, bottom-up: top-down, limnology, biotic community, water quality. 


\section{LISTA DE FIGURAS}

1 Processos internos de um reservatório. As letras $\mathrm{A}$ até $\mathrm{S}$ pertencem ao subsistema físico, os processos $\mathrm{F}, \mathrm{G}, \mathrm{K}, \mathrm{L}$ ao subsistema químico e os restantes ao subsistema biológico (Fonte: STRAŠKRABA \& TUNDISI, 2000).

Efeito Top-Down : Bottom-up (Fonte: CARPENTER \& KITCHELL, 1993, modificado).

3 Comparação entre complexidades das interações entre ambientes temperados e tropicais (Fonte: STARLING \& LAZZARO, 2000). Bacia do Rio Paraná, com distribuição dos reservatórios (Fonte: Itaipu Binacional, 2006).

Morfometria e locais de amostragem no reservatório de Itaipu, com as zonas fluvial, transição e lacustre adotadas no programa de monitoramento.

Variação da pluviosidade (média trimestral) de acordo com as zonas do reservatório de Itaipu, para o período de 1999 a 2004.

Variação dos valores de temperatura (média trimestral) e distribuição de acordo com as zonas do reservatório de Itaipu, para o período de 1999 a 2004 ..

8 Variação dos valores de transparência da água (média trimestral) de acordo com as zonas do reservatório de Itaipu, para o período de 1999 a 2004.

Variação dos valores de sólidos suspensos totais (média trimestral) de acordo

10 Variação dos valores de turbidez (média trimestral) de acordo com as zonas do reservatório de Itaipu, para o período de 1999 a $2004 .$.

11 Variação dos valores de alcalinidade (média trimestral) de acordo com as zonas do reservatório de Itaipu, para o período de 1999 a 2004

12 Variação dos valores de $\mathrm{pH}$ (média trimestral) de acordo com as zonas do reservatório de Itaipu, para o período de 1999 a 2004.

13 Variação dos valores de condutividade (média trimestral) de acordo com as zonas do reservatório de Itaipu, para o período de 1999 a 2004

14 Variação da concentração de oxigênio dissolvido (média trimestral) de acordo com as zonas do reservatório de Itaipu, para o período de 1999 a 2004.

15 Variação da DBO (média trimestral) de acordo com as zonas do reservatório de Itaipu, para o período de 1999 a 2004.

16 Variação dos valores de DQO (média trimestral) de acordo com as zonas do reservatório de Itaipu, para o período de 1999 a 2004.

17 Variação das concentrações de nitrato (média trimestral) de acordo com as zonas do reservatório de Itaipu, para o período de 1999 a $2004 .$.

18 Variação da concentração de nitrito (média trimestral) de acordo com as zonas do reservatório de Itaipu, para o período de 1999 a 2004.

19 Variação da concentração de TKN (média trimestral)de acordo com as zonas do reservatório de Itaipu, para o período de 1999 a 2004.

20 Variação da concentração de nitrogênio amoniacal (média trimestral) de acordo com as zonas do reservatório de Itaipu, para o período de 1999 a 2004. ..

21 Variação da concentração de fósforo total (média trimestral) de acordo com as zonas do reservatório de Itaipu, para o período de 1999 a 2004

22 Variação da concentração de clorofila (média trimestral) de acordo com as zonas do reservatório de Itaipu, par o período de 1999 a 2004.

23 Relação entre (a) $\ln s$ (logaritmo neperiano da profundidade de disco de secchi) 
e lnso (logaritmo neperiano da concentração de sólidos suspensos) e (b) $\ln s$ (logaritmo neperiano da profundidade de disco de secchi) e $\ln t$ (logaritmo neperiano da concentração de turbidez).

24 Distribuição dos resíduos studentizados em função dos valores estimados pelo modelo de regressão $\ln s=\mu+\ln s o+\ln t+\varepsilon$, para os dados das variáveis limnológicas, onde lnso é o logaritmo neperiano da concentração de sólidos suspensos, $\ln t$ é o logaritmo neperiano da concentração de turbidez e $\varepsilon$ é o erro experimental.

25 Histograma dos resíduos do modelo final da regressão $\ln s=\mu+\ln t+\ln s o+\varepsilon$, para os dados das variáveis limnológicas, onde $\ln t$ é o logaritmo neperiano da concentração de turbidez, lnso é o logaritmo neperiano da concentração de sólidos suspensos e $\varepsilon$ é o erro experimental.........

26 Relação entre lncloro e $\ln n$ _amo (a) e $\ln$ cloro e $\ln T K N$ (b) (lncloro é o logaritmo neperiano da concentração de clorofila, $\ln n \_a m o$ é o logaritmo neperian.o da concentração de nitrogênio amoniacal e $\operatorname{lnTKN}$ é logaritmo neperiano de TKN)

27 Distribuição dos resíduos studentizados em função dos valores estimados pelo modelo ANCOVA $\ln$ cloro $=\mu+Z R+\ln t k n+\ln n_{-} a m o+\varepsilon$, para os dados das variáveis limnológicas, onde $Z R$ é a zona do reservatório (1= Fluvial, $2=$ Transição, 3= Lacustre), lntkn é o logaritmo da concentração de TKN, $\ln n \_a m o$ é o logaritmo neperiano da concentração de nitrogênio amoniacal e $\varepsilon$ é o erro experimental.

28 Histograma dos resíduos do modelo final da ANCOVA $\ln$ cloro $=\mu+Z R+\ln T K N+\ln n_{-}$amo $+\varepsilon$, para os dados das variáveis limnológicas, onde $Z R$ é a zona do reservatório (1= Fluvial, $2=$ Transição, $3=$ Lacustre), lntkn é o logaritmo neperiano da concentração de TKN, $\ln n$ amo é o logaritmo neperiano da concentração de nitrogênio amoniacal e $\varepsilon$ é o erro experimental.

29 Médias ajustadas de lncloro para as zonas do reservatório, com $1=$ Fluvial, $2=$ Transição e 3 = Lacustre. As barras verticais indicam o erro padrão da média ajustada

30 Relação entre lncianoba (logaritmo neperiano da concentração de cianobactérias) e $\ln T K N$ (logaritmo neperiano de TKN)....

31 Distribuição dos resíduos studentizados em função dos valores estimados pelo modelo ANCOVA $\ln$ cianoba $=\mu+Z R+\ln T K N+\varepsilon$, para os dados das variáveis limnológicas, onde $Z R$ é a zona do reservatório (1= Fluvial, $2=$ Transição, $3=$ Lacustre), $\ln T K N$ é o logaritmo de TKN e $\varepsilon$ é o erro experimental.

32 Histograma dos resíduos do modelo final da ANCOVA $\ln$ cianoba $=\mu+Z R+\ln T K N+\varepsilon$, para os dados das variáveis limnológicas, onde $Z R$ é a zona do reservatório (1= Fluvial, $2=$ Transição, $3=$ Lacustre), $\ln T K N$ é o logaritmo neperiano de TKN e $\varepsilon$ é o erro experimental.

33 Médias ajustadas de lncianoba para as zonas do reservatório, com 1 = Fluvial, $2=$ Transição e $3=$ Lacustre. As barras verticais indicam o erro padrão da média ajustada.

4 Variação do IET (Secchi) (média trimestral) pelas zonas do reservatório de Itaipu, para o período de 1999 a 2004.

35 Variação do IET (clorofila) (média trimestral) pelas zonas do reservatório de Itaipu para o período de 1999 a 2004 
36 Variação do IET (fósforo total) (média trimestral) pelas zonas do reservatório de Itaipu para o período de 1999 a 2004.

37 Variação do IET (médio) (média trimestral) de acordo com as zonas do reservatório de Itaipu, para o período de 1999 a 2004.

38 Variação da comunidade fitoplanctônica de acordo com as zonas do reservatório de Itaipu, para o período de 1999 a 2004.

39 Variação da abundância relativa do fitoplâncton de acordo com as zonas do reservatório de Itaipu, para o período de 1999 a 2004.

40 Variação da abundância numérica do zooplâncton de acordo com as zonas do reservatório de Itaipu, para o período de 1999 a 2004.

41 Variação da abundância relativa do zooplâncton de acordo com as zonas do reservatório de Itaipu, para o período de 1999 a 2004.

42 Variação do peso de peixes de acordo com as guildas tróficas e zonas do reservatório de Itaipu, para o período de 2000 a 2004.

43 Variação da abundância relativa das guildas tróficas dos peixes de acordo com as zonas do reservatório de Itaipu, para o período de 1999 a $2004 .$.

44 Correlação entre log de piscívoros e (a) onívoro, (b) bentívoro, (c) detritívoro e (d) zooplanctófago para o reservatório de Itaipu, para o período de 2000 a 2004 ......

45 Correlação entre $\log$ de onívoros e (a) bentófago, (b) detritívoro e (c) zooplanctófago para o reservatório de Itaipu, para o período de 2000 a $2004 . . .$.

46 Correlação entre os log de iliófagos e (a) cladóderos e (b) copépodos, para o reservatório de Itaipu, para o período de 2000 a 2004.

47 Correlação entre (a) $\log$ de cladódera e $\log$ clorofila e (b) $\log$ de copépoda e $\log$ de clorofila, para o reservatório de Itaipu, para o período de 2000 a $2004 \ldots .$.

48 Correlação entre clorofila e fósforo total (a) e TKN (b) do reservatório de Itaipu, com os dados médios agrupados por zona.

49 Correlação entre (a) $\log$ de onívoro e $\log$ de clorofila, (b) $\log$ de insetívoro e $\log$ de clorofila, (c) $\log$ de detritívoro e $\log$ de clorofila e (d) $\log$ de iliófago e log de clorofila, para o reservatório de Itaipu, para o período de 2000 a $2004 \ldots$.

50 Correlação entre (a) $\log$ de insetívoro e $\log \mathrm{P}$ total e (b) $\log$ de herbívoro e $\log$ de P total, para o reservatório de Itaipu, para o período de 2000 a 2004.

Correlação entre (a) $\log$ de onívoros e $\log$ de cianobactérias, (b) $\log$ de insetívoros e $\log$ de cianobactérias, (c) $\log$ de detritívoros e $\log$ de cianobactérias e (d) $\log$ de zooplanctófagos e log de cianobactérias, para o reservatório de Itaipu, para o período de 2000 e 2004.

52 Correlação entre log de clorofila e log de cianobactérias para o reservatório de Itaipu, para o período de 1999 a 2004.

53 Relação entre lncianoba e lnonivoro (lncianoba é o logaritmo neperiano da concentração de cianobactérias e lnonivoro é o logaritmo neperiano do peso total dos peixes onívoros).

54 Distribuição dos resíduos studentizados em função dos valores estimados pelo modelo ANCOVA $\ln$ ciano $=\mu+Z R+\ln$ onivoro $+\varepsilon$, para os dados das variáveis limnológicas e das guildas tróficas de peixes, onde $Z R$ é a zona do reservatório ( $1=$ Fluvial, $2=$ Transição, $3=$ Lacustre), lnonivoro é o logaritmo do peso total dos peixes onívoros e $\varepsilon$ é o erro experimental.....

55 Histograma dos resíduos do modelo final da ANCOVA $\ln$ ciano $=\mu+Z R+\ln$ onivoro $+\varepsilon$, para os dados das variáveis limnológicas e das guildas tróficas dos peixes, onde $Z R$ é a zona do reservatório (1= Fluvial, $2=$ Transição, $3=$ Lacustre), lnonivoro é o logaritmo neperiano do peso total 
dos peixes onívoros e $\varepsilon$ é o erro experimental.

56 Médias ajustadas de lnciano para as zonas do reservatório, com 1 = Fluvial, 2 $=$ Transição e $3=$ Lacustre. As barras verticais indicam o erro padrão da média ajustada.

57 Relação entre lncloro e lndetritivoro (lncloro é o logaritmo neperiano da concentração de clorofila e lndetritivoro é o logaritmo neperiano do peso total dos peixes detritívoros).

58 Distribuição dos resíduos studentizados em função dos valores estimados pelo modelo ANCOVA $\ln$ clorofila $=\mu+Z R+\ln$ detritivoro $+\varepsilon$, para os dados das variáveis limnológicas e das guildas tróficas de peixes, onde $Z R$ é a zona do reservatório (1=Fluvial, $2=$ Transição, 3= Lacustre), lndetritivor é o logaritmo do peso dos peixes detritívoros e $\varepsilon$ é o erro experimental.

59 Histograma dos resíduos do modelo final da ANCOVA $\ln$ clorofila $=\mu+Z R+\ln$ detritivor $+\varepsilon, \quad$ para os dados das variáveis limnológicas e das guildas tróficas dos peixes, onde $Z R$ é a zona do reservatório ( $1=$ Fluvial, $2=$ Transição, $3=$ Lacustre), lndetritivor é o logaritmo neperiano do peso dos peixes detritívoros e $\varepsilon$ é o erro experimental.

60 Médias ajustadas de lnclorofila para as zonas do reservatório, com 1 = Fluvial, $2=$ Transição e $3=$ Lacustre. As barras verticais indicam o erro padrão da média ajustada.

61 Análise da regressão entre log de cianobactérias e log de captura, para o reservatório de Itaipu, no o período de 2000 a 2004.

62 Distribuição dos resíduos (a) e histograma dos resíduos (b) do modelo da regressão $\ln$ captura $=\mu+\ln$ cianobactérias $+\varepsilon$, onde lncaptura é o logaritmo neperiano da captura, lncianobactérias é o logaritmo neperiano das concentrações de cianobactérias e $\varepsilon$ é o erro experimental...

63 Estimativa da produtividade pesqueira (FY) em kg/ha/ano de acordo com as zonas do reservatório de Itaipu, para o período de 1999 a 2004.

64 Análise de correlação entre a transparência da água (a) e clorofila-a (b) com o índice morfedáfico (MEI) para o reservatório de Itaipu, para o período de 1999 a 2004

65 Mapa topogáfico do vale do reservatório de Itaipu. O lago de Itaipu está localizado na porção central do vale. As linhas horizontais representam a latitude das estações meteorológicas (fonte: STIVARI et al. 2005)..

66 Distribuição do uso da terra nas áreas próximas do reservatório de Itaipu, apresentando quatro classes dominantes de ocupação da superfície: lago e rios (azul); floresta (verde); pasto (amarelo) e atividade de agricultura (vermelho) (Fonte: STIVARI et al., 2005).

67 Efeito negativo da cascata trófica em ambientes temperados (Fonte: LAZZARO, 2002)

68 Ausência de relações diretas na cascata trófica em ambientes tropicais.

69 Efeitos diretos e indiretos na cascata trófica do reservatório de Itaipu.

70 Rede trófica do reservatório de Itaipu. As setas direcionadas para baixo e em cor vermelha indicam um efeito top-down, as setas com ponto e risco e em cor verde indicam um efeito bottom-up, as setas pontilhadas indicam um efeito indireto, as espessuras das setas indicam o coeficiente de correlação destas relações e as cores indicam os diferentes níveis tróficos (peixes, zooplâncton, fitoplâncton e nutrientes). 


\section{LISTA DE TABELAS}

Efeitos positivos e negativos decorrentes da construção de reservatório.... Localização das estações de amostragem no reservatório de Itaipu... Variáveis limnológicas e metodologias de análises.

Resultados da análise de regressão aplicada no modelo $\ln s=\mu+\ln s o+\ln t+\varepsilon$, para os dados das variáveis limnológicas, onde $\ln t$ é o logaritmo neperiano da concentração de turbidez, lnso é o logaritmo neperiano da concentração de sólidos suspensos e $\varepsilon$ é o erro experimental.

Resultados da ANCOVA aplicada no
modelo $\ln$ cloro $=\mu+Z R+\ln t k n+\ln n \_a m o+\varepsilon$, para os dados das variáveis limnológicas, onde $Z R$ é a zona do reservatório ( $1=$ fluvial; $2=$ transição; $3=$ lacustre) e lntkn é o logaritmo neperiano da concentração de TKN, $\ln n \_a m o$ é o logaritmo neperiano da concentração de nitrogênio amoniacal e $\varepsilon$ é o erro experimental...

Teste a posteriori entre as médias ajustadas de lncianoba (logaritmo neperiano da concentração de cianobactérias) obtidas a partir do modelo final da ANCOVA $\ln$ cloro $=\mu+Z R+\ln T K N+\ln n+a m o+\varepsilon$ para as três zonas do reservatório ( $1=$ Fluvial; $2=$ Transição; $3=$ Lacustre). Os números entre parêntesis representam os antilogaritmos das médias ajustadas (concentração de clorofila), em escala aritmética...

Resultados da ANCOVA aplicada no modelo $\ln$ cianoba $=\mu+Z R+\ln T K N+\varepsilon, \quad$ para os dados das variáveis limnológicas, onde $Z R$ é a zona do reservatório ( $1=$ fluvial; $2=$ transição; $3=$ lacustre) e $\ln T K N$ é o logaritmo neperiano de TKN e $\varepsilon$ é o erro experimental.....

Teste a posteriori entre as médias ajustadas de lncianoba (logaritmo neperiano da concentração de cianobactérias) obtidas a partir do modelo final da ANCOVA $\ln$ cianoba $=\mu+Z R+\ln T K N+\varepsilon$ para as três zonas do reservatório $(1=$ Fluvial; $2=$ Transição; $3=$ Lacustre). Os números entre parêntesis representam os antilogaritmos das médias ajustadas (concentração de cianobactérias), em escala aritmética.

Relação dos táxons de fitoplâncton identificados no reservatório de Itaipu durante o período de estudo.

Composição do zooplâncton no reservatório de Itaipu durante o período de 1999 a 2004.

Principais espécies de peixes, nomes científicos e guildas tróficas do reservatório de Itaipu, durante o período de 2000 a 2004.

Distribuição dos pesos e abundâncias das guildas tróficas dos peixes para o reservatório de Itaipu.

da ANCOVA aplicada no modelo ln ciano $=\mu+Z R+\ln$ onivoro $+\varepsilon$, para os dados das variáveis limnológicas e das guildas tróficas de peixes, onde $Z R$ é a zona do reservatório ( $1=$ fluvial; $2=$ transição; $3=$ lacustre) e lnonivoro é o logaritmo neperiano do peso total dos peixes onívoros e $\varepsilon$ é o erro experimental.

14 Teste a posteriori entre as médias ajustadas de lnciano (logaritmo 
neperiano da concentração de cianobactérias) obtidas a partir do modelo final da ANCOVA $\ln$ ciano $=\mu+Z R+\ln$ onivoro $+\varepsilon$ para as três zonas do reservatório $(1=$ Fluvial; $2=$ Transição; $3=$ Lacustre). Os números entre parêntesis representam os antilogaritmos das médias ajustadas (concentração de cianobactérias), em escala aritmética..............................

15 Resultados da ANCOVA aplicada no modeloln cloro $=\mu+Z R+\ln$ detritivor $+\varepsilon$, para os dados das variáveis limnológicas e das guildas tróficas de peixes, onde $Z R$ é a zona do reservatório ( $1=$ fluvial; $2=$ transição; $3=$ lacustre) e lndetritivor é o logaritmo neperiano do peso total dos peixes detritívoros e $\varepsilon$ é o erro experimental.

16 Teste a posteriori entre as médias ajustadas de lnclorofila (logaritmo neperiano da concentração de clorofila) obtidas a partir do modelo final da ANCOVA $\ln$ cloro $=\mu+Z R+\ln$ detritivor $+\varepsilon$ para as três zonas do reservatório ( $1=$ Fluvial; $2=$ Transição; $3=$ Lacustre). Os números entre parêntesis representam os antilogaritmos das médias ajustadas (concentração de clorofila), em escala aritmética.......................................

17 Resultados da análise de regressão aplicada no modelo $\ln$ captura $=\mu+\ln$ cianobactéria $+\varepsilon$, onde lncaptura é o logaritmo neperiano da captura, lncianobactéria é ologaritmo neperiano da concentração de cianobactéria e $\varepsilon$ é o erro experimental...

18 Comparação entre os valores médios das zonas fluvial, transição e lacustre no reservatório de Itaipu com os valores propostos pela resolução CONAMA (357/05). 


\section{SUMÁRIO}

1. INTRODUÇÃO …………………………………………………..... 1

1.1. A pesca no reservatório de Itaipu........................................................ 5

1.2. Relação entre peixes e qualidade da água........................................... 6

1.3. Definição de cascata trófica top-down : bottom-up .............................. 7

1.4. Interações de cascata trófica em lagos e reservatórios.......................... 8

1.5. Cascatas tróficas em ambientes tropicais e subtropicais...................... 13

1.6. Biomanipulação como ferramenta de manejo de cascatas tróficas: conceito e técnicas aplicadas............................................................... 14

1.7. Estratégias de manejo de peixes baseadas na estocagem de peixes

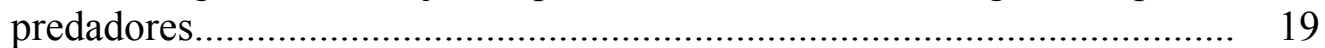

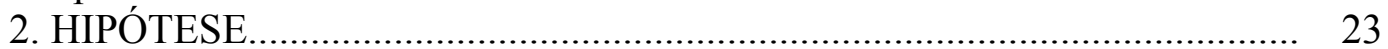

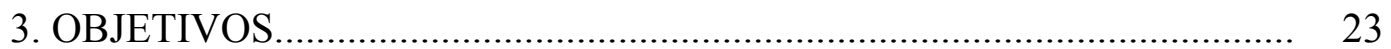

4. MATERIAL E MÉTODOS............................................................... 24

4.1. Caracterização da área de estudo...................................................... 24

4.2. Caracterização das estações de amostragem......................................... 29

4.3. Aquisição dos dados..................................................................... 30

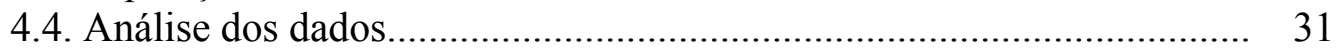

4.4.1. Fitoplâncton......................................................................... 31

4.4.2. Zooplâncton............................................................................ 32

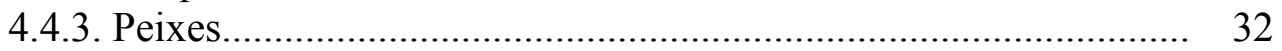

4.4.4. Análise dos níveis tróficos.................................................. 32

4.5 Análise estatística dos dados........................................................ 32

4.5.1 Análise das variáveis limnológicas.............................................. 33

4.5.2. Análise das variáveis biológicas (guildas de peixes, fitoplâncton e zooplâncton) e nutrientes (fósforo total e TKN)................................. 34

4.5.3. Análises de Covariância (ANCOVA)........................................... 34

4.6. Índice de estado trófico (IET) ......................................................... 36

4.7. Estimativa da produtividade pesqueira............................................. 36

4.7.1 Inferência da produtividade pesqueira........................................... 37

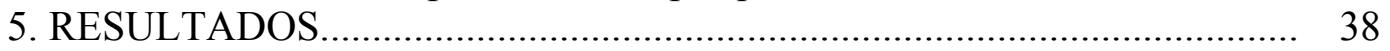

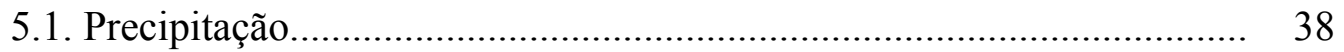

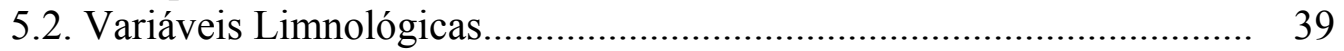

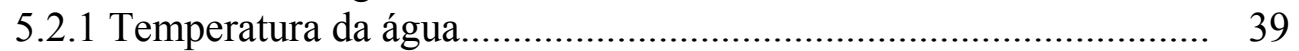

5.2.2. Transparência da água........................................................... 39

5.2.3. Sólidos suspensos totais......................................................... 40

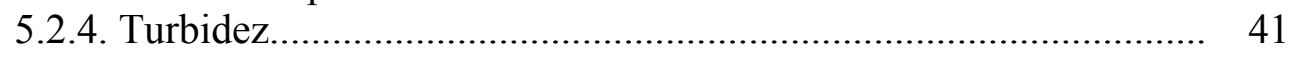

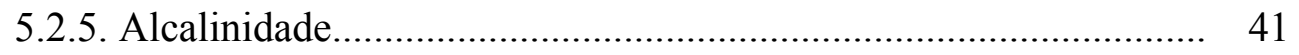

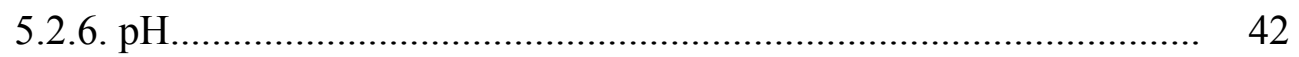

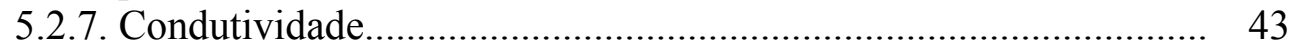

5.2.8. Oxigênio dissolvido (OD) ......................................................... 43

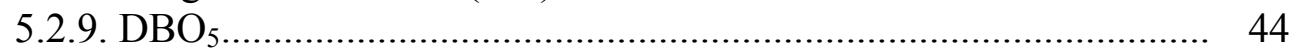

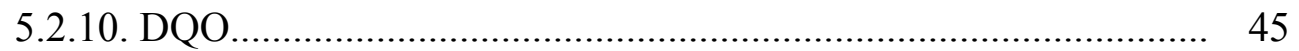

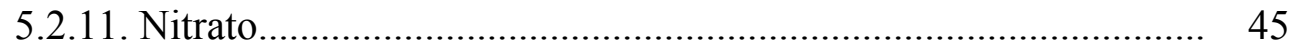

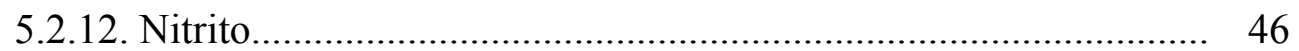

5.2.13. Nitrogênio total kjeldahl (TKN) ........................................... 47

5.2.14. Nitrogênio amoniacal........................................................... 47

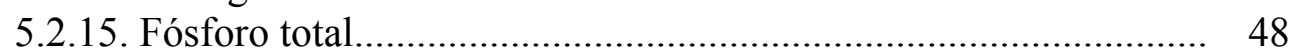


5.2.17. Ralações entre as variáveis limnológicas..

5.2.17.1. Relação entre profundidade (disco de secchi), concentração de sólidos suspensos e concentração de turbidez.

5.2.17.2. Relação entre concentração de clorofila-a, concentração de

TKN e concentração de nitrogênio amoniacal..

5.2.17.3. Relação entre concentração de cianobactérias e concentração de TKN.

5.2.18. Índice de estado Trófico........................................................ 60

5.3. Composição, densidade e abundância relativa do fitoplâncton............. 63

5.4. Composição, densidade e abundância relativa do zooplâncton.............. 66

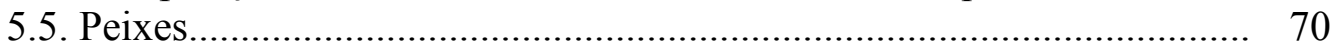

5.5.1. Caracterização das guildas tróficas de peixes.............................. 70

5.5.2. Distribuição das guildas tróficas de peixes................................... 71

5.5.3. Distribuição da abundância relativa das guildas tróficas de peixes 72

5.6. Análise das interações tróficas no Reservatório de Itaipu: Efeitos diretos.

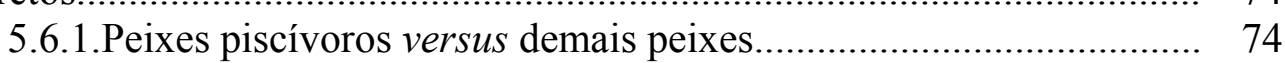

5.6.2. Onívoros versus demais peixes............................................... 75

5.6.3. Peixe versus zooplâncton........................................................... 75

5.6.4. Macrozooplâncton versus clorofila................................................. 76

5.6.5. Clorofila versus fósforo total e TKN........................................ 77

5.7. Análise das interações tróficas no Reservatório de Itaipu: Efeitos Indiretos.

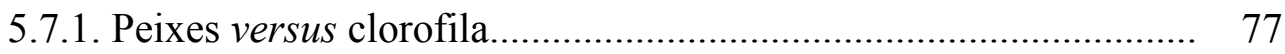

5.7.2. Peixe versus fósforo total.................................................... 78

5.7.3. Peixes versus cianobactérias....................................................... 79

5.7.4. Clorofila versus cianobactéria..................................................... 79

5.7.5. Análise da relação de cianobactérias com o fósforo total e peixes no reservatório de Itaipu.

5.7.5.1. Relação entre as concentrações de cianobactérias e guildas de peixes.

5.7.5.2. Relação entre concentração de cianobactérias e peixes onívoros.

5.7.5.3. Relações entre concentração de clorofila e detritívoros.......... 84

5.8. Inferência da Produção Pesqueira......................................................... 88

5.8.1. Correlações entre MEI, clorofila-a e transparência da água.......... 90

6. DISCUSSÃO

6.1. Limnologia do reservatório de Itaipu................................................ 91

6.2. Índice de estado trófico (IET) ............................................................ 101

6.3. Análise da distribuição longitudinal das comunidades biológicas (fitoplâncton, zooplâncton e peixes).

6.4. Relações tróficas (top-down e bottom-up) no reservatório de Itaipu:

Efeitos diretos e indiretos.

6.5. Inferência da produção pesqueira...................................................... 117

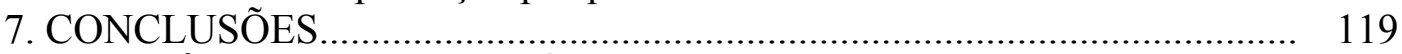

8. REFERÊNCIAS BIBLIOGRÁFICAS............................................... 122 


\section{INTRODUÇÃ̃O}

Os reservatórios são ambientes artificiais, intermediários entre rios e lagos, apresentando características morfométricas e hidrológicas distintas, com alta taxa de renovação da água e uma organização vertical e horizontal no lago bem característica, na qual sua evolução depende de inúmeras variáveis em escala espacial e temporal (MARGALEF, 1975). A característica diferenciada dos reservatórios baseia-se na heterogeneidade espacial (região de rio, zona de transição e região lacustre) e no tempo de residência da água (dependente dos mecanismos operacionais do reservatório), implicando em alterações nas características físicas, químicas e biológicas da água, o que também estão associados aos eventos climatológicos.

Os reservatórios são semelhantes a lagos quanto aos processos ecológicos básicos que envolvem o metabolismo dos ecossistemas aquáticos (WETZEL, 1990). Entretanto, a necessidade de regulação de sua vazão pela demanda de produção de energia ou com outros propósitos, faz com que esses ambientes tenham seu nível de água, profundidade e tempo de residência bastante alterados, o que pode causar modificações acentuadas nas propriedades físicas, químicas e biológicas do ambiente e, conseqüentemente, as respostas do sistema podem se diferenciar amplamente em relação aos lagos. O autor admite, todavia, que as características estruturais físicas e bióticas são fortemente divergentes das propriedades gerais dos ecossistemas lacustres naturais, pois enquanto que os lagos têm sua história em uma escala do tempo geológico, os reservatórios foram criados pelo homem recentemente.

De acordo com STRAŠKRABA \& TUNDISI (2000), quando se discutem aspectos ligados à qualidade da água, é preciso considerar o ecossistema dividido em subsistemas que interagem entre si: (a) a bacia hidrográfica; (b) as vazões afluentes; (c) o reservatório em si; (d) as vazões liberadas e (e) a socioeconomia e o gerenciamento. Os autores salientam que o reservatório é um coletor e digestor das entradas e dos 
impactos existentes nas bacias hidrográficas, gerando efeitos com modificações nos processos internos físicos, químicos e biológicos (Figura 1).

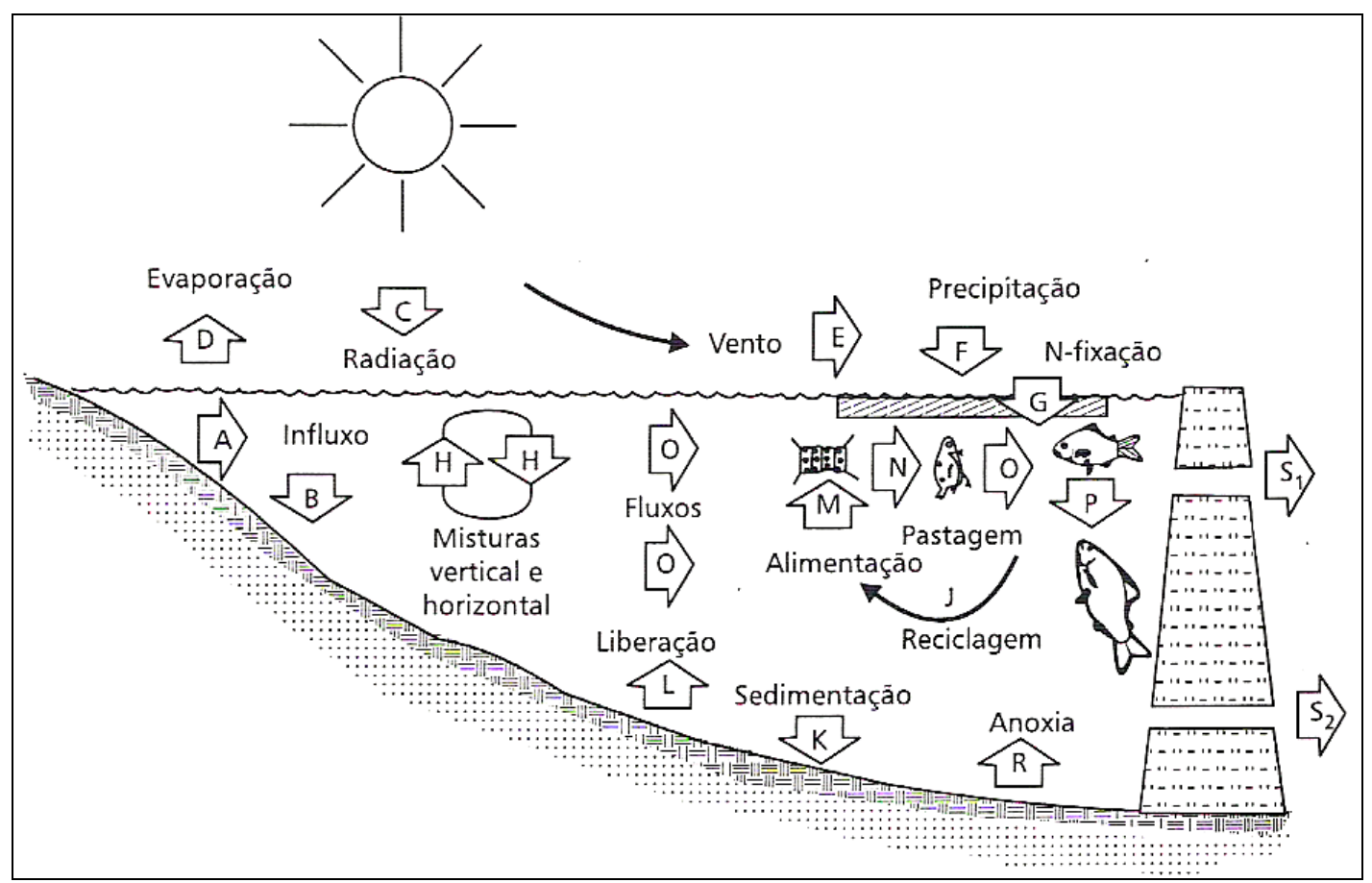

Figura 1: Processos internos de um reservatório. As letras $\mathrm{A}$ até $\mathrm{S}$ pertencem ao subsistema físico, os processos $\mathrm{F}, \mathrm{G}, \mathrm{K}, \mathrm{L}$ ao subsistema químico e os restantes ao subsistema biológico (Fonte: STRAS̆KRABA \& TUNDISI, 2000).

Segundo STRAŠKRABA \& TUNDISI (2000), uma das conseqüências mais impactantes na construção de uma barragem é a interrupção do fluxo de água entre o rio e o reservatório, implicando em uma alteração na estrutura das comunidades de peixes, com a proliferação de espécies sedentárias e a redução ou eliminação daquelas migradoras. As mudanças de um ambiente lótico para lêntico criam novos habitats nos quais muitas espécies de peixes de rio não estão adaptadas, tornando desabitada a região pelágica, que é a mais profunda em reservatórios. Os autores enfatizam que, para o desenvolvimento e a organização estrutural e funcional da fauna de peixes de um reservatório, devem-se considerar cinco processos:

1) a produtividade individual do reservatório imediatamente após seu enchimento,

2) a eutrofização e o fornecimento de nutrientes pelas bacias hidrográficas,

3) o desenvolvimento de complexas interações bióticas dentro do reservatório,

4) o regime hidrológico e

5) o gerenciamento do sistema. 
Embora a obstrução do acesso aos habitats de desova e de desenvolvimento inicial de espécies migradoras promovidos pela barragem sejam a causa primária da redução populacional dessas espécies, os efeitos cumulativos de outros fatores físicos e químicos (hidrológicos, geomorfológicos e de qualidade de água) também estão envolvidos (AGOSTINHO et al., 1997a). STRAŠKRABA \& TUNDISI (2000) e JØRGENSEN \& VOLLENWEIDER (2000) discutem amplamente os diversos efeitos positivos e negativos da construção de um reservatório (Tabela 1).

Os reservatórios são sistemas complexos que podem ser ainda divididos em três subsistemas ecológicos fundamentais: a bacia hidrográfica e sua rede hídrica, o reservatório e as descargas nele sofridas e o sistema a jusante. Esta rede interativa de componentes apresenta inúmeras características, como o funcionamento das estruturas que é determinada pelas forças climatológicas e hidrológicas, e são sistemas que apresentam a capacidade de auto-organização da estrutura de seus componentes, tanto no eixo horizontal como no vertical (TUNDISI, 2005). Segundo o autor, para se compreender os reservatórios e seus complexos sistemas, deve-se considerar três fatores básicos que interferem no seu funcionamento:

1) a barragem como base de funcionamento dinâmico do sistema;

2) a fase de enchimento do reservatório que constitui a base biogeofísica para a sua dinâmica e a regulação do fluxo de água e

3) o tempo de retenção do reservatório, que estabelece influências quali e quantitativas na água e na biota do reservatório.

O tempo de retenção intermediário entre reservatórios e lagos e os aportes predominantes a partir de uma fonte principal resultam em um pronunciado gradiente longitudinal das características limnológicas (STRAŠKRABA, 1998). Segundo KIMMEL et al., 1990 STRAŠKRABA \& TUNDISI (2000), ao longo do rio até a barragem, é possível observar três zonas que se diferenciam quanto às propriedades físicas, químicas e biológicas: a zona fluvial, a zona de transição e a zona lacustre. $\mathrm{O}$ dimensionamento dessas três regiões está fortemente relacionado ao influxo de água e a seu tempo de residência. Em geral, pode-se dizer que ocorre um aumento no tempo de residência, enquanto as concentrações de nutrientes e de seston decrescem na direção da barragem. Tais alterações, por sua vez, irão afetar as principais forças controladoras da produtividade fitoplanctônica em reservatórios, que são a carga de nutrientes e o tempo de residência, afetando, em conseqüência, as demais comunidades do reservatório (TUNDISI, 1990). 
Tabela 1: Efeitos positivos e negativos decorrentes da construção de reservatório (STRAŠKRABA \& TUNDISI (2000)).

\begin{tabular}{|c|c|}
\hline Efeitos Positivos & Efeitos Negativos \\
\hline Produção de energia & Deslocamento de populações \\
\hline $\begin{array}{l}\text { Criação de purificadores de água } \\
\text { com baixa energia }\end{array}$ & Emigração humana excessiva \\
\hline Retenção de água no local & Deteriorização das condições da população original \\
\hline $\begin{array}{l}\text { Fonte de água potável } \mathrm{p} / \text { sistema } \\
\text { de abastecimento }\end{array}$ & $\begin{array}{l}\text { Problemas de saúde pela propagação de doenças de } \\
\text { veiculação hídrica }\end{array}$ \\
\hline $\begin{array}{l}\text { Maior prosperidade para parte das } \\
\text { populações }\end{array}$ & Perda de espécies nativas de peixes de rios \\
\hline $\begin{array}{l}\text { Criação de possibilidades de } \\
\text { recreação }\end{array}$ & Perda de terras férteis e de madeira \\
\hline Proteção contra cheias a jusante & Perda de várzea e ecótones terra/água \\
\hline Aumento da possibilidade da pesca & $\begin{array}{l}\text { Perda de biodiversidade e deslocamento de animais } \\
\text { selvagens }\end{array}$ \\
\hline $\begin{array}{l}\text { Armazenamento de água para } \\
\text { períodos secos }\end{array}$ & Perda de terras agrícolas cultivadas a gerações \\
\hline Navegação & Excessiva imigração humana para a região do reservatório \\
\hline Aumento do potencial de irrigação & $\begin{array}{l}\text { Necessidade de compensação pela perda de terras } \\
\text { agrícolas, locais de pesca, habitações, etc. }\end{array}$ \\
\hline \multirow[t]{9}{*}{ Aquicultura } & Degradação da qualidade hídrica local \\
\hline & $\begin{array}{l}\text { Redução das vazões a jusante do reservatório e aumento } \\
\text { nas suas variações }\end{array}$ \\
\hline & $\begin{array}{l}\text { Redução na temperatura e no material em suspensão, nas } \\
\text { vazões liberadas a jusante }\end{array}$ \\
\hline & Redução de oxigênio no fundo e nas vazões liberadas \\
\hline & Barreira para migração de peixes \\
\hline & Perda de valiosos recursos históricos e naturais \\
\hline & Perda de valores estéticos \\
\hline & Descarga de nutrientes pela águas residuárias \\
\hline & Poluição difusa, chuvas ácidas e descargas térmicas \\
\hline
\end{tabular}

O metabolismo de um ecossistema aquático compreende três etapas principais: produção, consumo e decomposição (ESTEVES, 1988; WETZEL, 1993), sendo a primeira etapa deste metabolismo altamente dependente da luz e transparência nos ecossistemas aquáticos (CALIJURI et al., 1997; CALIJURI, 1989; HENRY, 1990). A cadeia trófica é a interação entre as etapas deste metabolismo.

De acordo com OVERBECK (2000), a estrutura de um ecossistema dulciaquícola é composta pelos componentes abióticos (substâncias inorgânicas, nutrientes, componentes orgânicos, regime climático) e bióticos (produtores, macroconsumidores como zooplâncton e peixes e os microconsumidores que são os organismos autotróficos e heterotróficos). Segundo o autor, essas funções são essenciais para o entendimento da dinâmica dos ecossistemas, e podem ser analisadas, funcionalmente, de acordo com o fluxo de energia, ciclagem de nutrientes, padrão do 
desenvolvimento e produtividade dos organismos em escala espacial e temporal, das cadeias alimentares e do controle (cibernético, regulação do metabolismo).

Segundo OVERBECK (2000), a transferência de energia de um nível trófico para outro é explicada pela pressão que o zooplâncton exerce sobre o fitoplâncton e a predação dos peixes sobre o plâncton, fazendo parte da cadeia alimentar. A cada transferência de um nível para outro se perde de 80 a $90 \%$ do potencial energético. As cadeias alimentares podem se inte-relacionar com outras cadeias formando um complexo sistema chamado de rede alimentar ou trófica. As cadeias alimentares podem ser divididas em dois grupos: a cadeia alimentar que começa com o fitoplâncton, passando pelo zooplâncton e chegando aos peixes, e a cadeia alimentar de detritos, que começa com a degradação da matéria orgânica por microrganismos decompositores, passando por organismos detritívoros e chegando aos peixes.

A produtividade pesqueira em represas é superior à das áreas lóticas da bacia, sendo esperado que a área alagada compense em alguma extensão as perdas dos trechos à jusante. Entretanto, a substituição de espécies de maior interesse econômico (migradoras) por aquelas com menor aceitação no mercado consumidor (lênticas), como verificado no reservatório de Itaipu (AGOSTINHO et al., 1994), reduz a importância socioeconômica dessa tendência de compensação.

A utilização de modelos empíricos que estimam a produtividade pesqueira em lagos e reservatórios é bem difundida, principalmente em ambientes africanos e norte americanos. Diversos trabalhos demonstram que muitas variáveis independentes podem ser correlacionadas às capturas de pescado, gerando modelos preditivos de produtividade (MELACK, 1976; HENDERSON \& WELCOMME, 1974; OGLESBY, 1977; MARSHALL, 1984). A utilização destas relações com o índice morfoedáfico (MEI) proposto por RYDER 1965, pode gerar informações importantes para o gerenciamento de ecossistemas aquáticos, como verificado no caso do lago Ontário, no Canadá.

\subsection{A pesca no reservatório de Itaipu}

AGOSTINHO et al. (1999) descreveram o histórico da pesca na região do reservatório, desde antes da construção até os dias de hoje. Segundo os autores, até a 
década de 60, a pesca no rio Paraná, na área do futuro reservatório de Itaipu, foi realizada apenas por pequenos povoados de Foz de Iguaçu e Guaíra, e os pescadores pioneiros vieram da bacia do Uruguai, cuja comunidade íctica era semelhante, e os mesmos já possuíam o conhecimento das técnicas e petrechos de pescas ideais para as pescarias. Os autores salientam que existia uma grande dificuldade de acesso ao rio Paraná, cuja precariedade do sistema viário impedia o desenvolvimento e comercialização, travando o desenvolvimento da atividade pesqueira na região.

O alavancamento desta atividade na década de 70 foi causado pela substituição do policultivo (realizado a base de força animal) pela rotação de culturas de soja e trigo (mecanização e pesticidas). Esta modernização provocou desemprego na época e a atividade pesqueira se tornou a opção de sustento.

As primeiras colônias de pesca surgiram no final da década de 60, uma em Foz de Iguaçu e outra em Guaíra. A organização dos pescadores e as possibilidades de conservação e o armazenamento incrementaram a comercialização do pescado, impulsionando a atividade e expandindo suas áreas de abrangência.

A atividade pesqueira no reservatório foi proibida por dois anos, de outubro de 1982 a fevereiro de 1985. Em junho de 1985 o acompanhamento da produção de peixes pelos pescadores começou a ser realizado pela superintendência dos Recursos Hídricos e Meio Ambiente (SUREHMA), e em 1987 a Universidade Estadual de Maringá montou a rede de monitoramento do desembarque pesqueiro no reservatório de Itaipu perdurando até os dias atuais.

\subsection{Relação entre os peixes e qualidade da água}

Os peixes desempenham um papel importante na biocenose do reservatório, se analisado em relação à qualidade da água. A presença ou ausência de determinadas espécies, aliada à quantidade de peixes existentes no sistema, ajuda a determinar a composição e quantidade de nutrientes, de zooplâncton e fitoplâncton presentes nos reservatórios (STRAŠKRABA \& TUNDISI, 2000).

A ictiofauna de um reservatório é alterada de acordo com as características da qualidade da água, devido a dois fatores: (a) contaminação por poluentes via tributários, que pode influenciar diferentes partes do reservatório e (b) mudanças na operação do 
sistema hidrológico (STRAŠKRABA \& TUNDISI, 2000). A composição das espécies da fauna depende em grande parte das características geográficas e, lagos e reservatórios caracterizam-se pela ausência de verdadeiras espécies pelágicas, sendo a maioria dos reservatórios povoada por espécies que habitam a região litoral. As concentrações de oxigênio dissolvido e os valores de pH são de extrema importância na presença de espécies de peixes. Em ambientes temperados, concentrações mínimas de oxigênio dissolvido para a permanência de peixes é de $2 \mathrm{mg} / \mathrm{l}$, e valores de $\mathrm{pH}$ inferiores a 4,5 é fator limitante na presença de peixes.

A introdução de espécies exóticas em um reservatório pode acarretar grandes problemas para seu gerenciamento. A falta de conhecimento científico sobre a cadeia trófica e as interações entre as espécies e as taxas de crescimento das populações induzem situações complexas, acarretando a predominância de espécies não desejáveis. O gerenciamento dos estoques pesqueiros deve ter início com a classificação das espécies existentes e sua diversidade, e a estrutura da rede alimentar e as relações reguladoras, como a interação predador-presa.

Dependendo dos nichos alimentares existentes no sistema, o impacto das espécies introduzidas pode ser menor, caso elas venham a colonizar nichos com poucos competidores. ZARET \& PAINE (1973) estudaram o Lago Kariba, no qual foram introduzidas espécies planctófagas que exploraram a zona pelágica com sucesso. Os mesmos autores documentaram grandes mudanças na cadeia alimentar no Lago Gatun (Panamá) após a introdução do tucunaré.

\subsection{Definição de cascata trófica top-down : bottom-up}

A teoria de cascata trófica em lagos e reservatórios é baseada em dois princípios: 1. Perda de energia entre um nível trófico e outro;

2. A perturbação de um nível trófico terá conseqüências nos demais níveis tróficos.

A figura 2 descreve os ciclos alimentares, que são responsáveis pela estrutura da cascata trófica em lagos e reservatórios, no qual um aumento em biomassa de piscívoros causa uma diminuição na biomassa de planctívoros, aumentando a biomassa de herbívoro causando uma diminuição na biomassa de fitoplâncton, todos estes efeitos via predação. O efeito top-down ocorre quando a biomassa de piscívoros, último nível 
trófico, apresenta efeito em cascata nos demais níveis até o primeiro, que são os produtores primários. $\mathrm{O}$ efeito bottom-up se caracteriza quando os produtores primários apresentam efeito nos demais níveis tróficos subseqüentes (Figura 2).

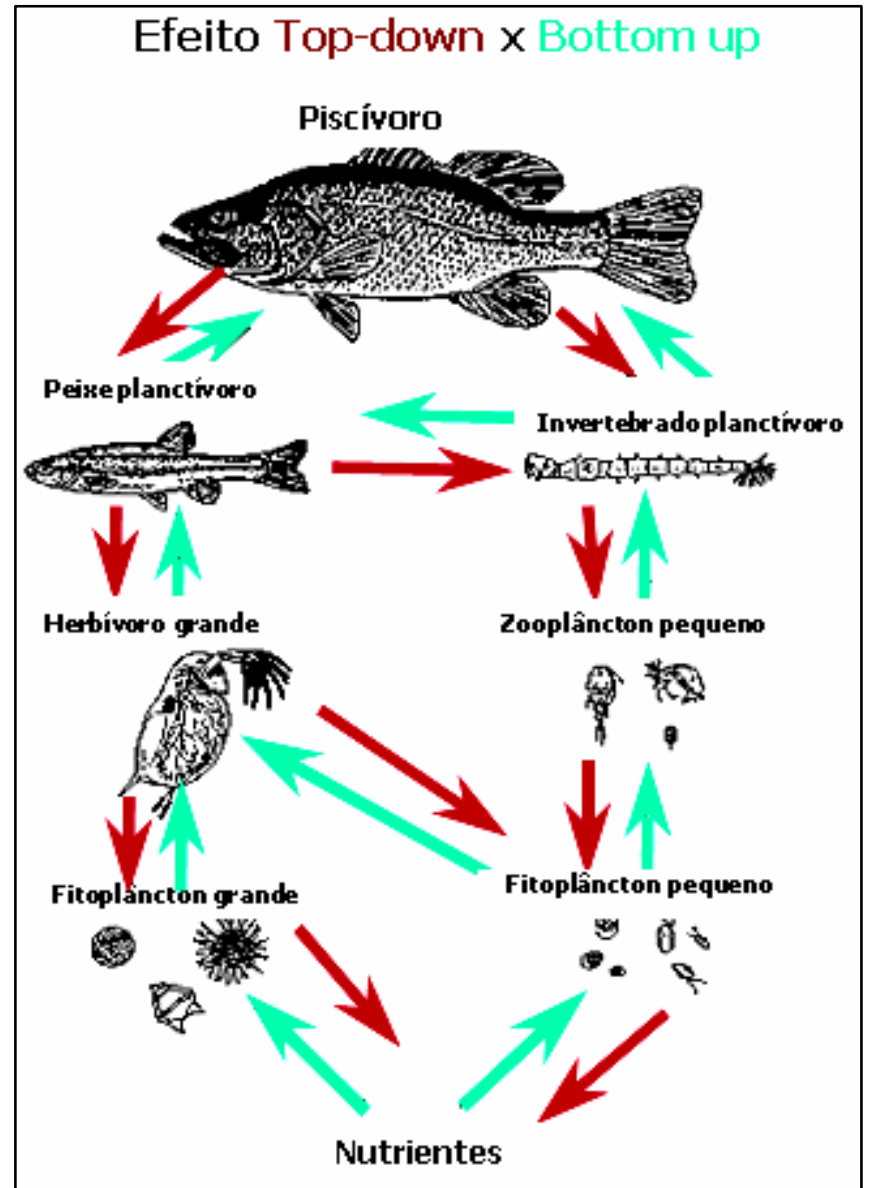

Figura 2: Efeito Top-Down:Bottom-up (Fonte: CARPENTER \& KITCHELL, 1993, modificado).

\subsection{Interações de cascata trófica em lagos e reservatórios}

O trabalho pioneiro de HRBÁČEK et al. (1961) foi responsável por evidenciar o efeito dos peixes sobre a estrutura da cadeia alimentar aquática. Após alguns anos, pesquisas como as de BROOKS \& DODSON (1965) e SHAPIRO et al. (1975) contribuíram para o desenvolvimento da teoria das redes tróficas lacustres, revelando o importante papel dos peixes, ignorados no campo da limnologia durante décadas.

O primeiro livro que trata o efeito cascata em lagos foi o "The trophic cascade in lakes" (CARPENTER \& KITCHELL, 1993). Nesta obra os autores discutiram temas como: interações de cascata trófica, o comportamento dos peixes em respostas às 
manipulações, dinâmica do fitoplâncton e zooplâncton, interação entre a produtividade primária e nutrientes, simulações de modelos de cascata trófica, entre outros, sendo de grande importância para o entendimento do funcionamento dos efeitos da cascata trófica em ecossistemas aquáticos.

As teorias de cascatas tróficas (CARPENTER \& KITCHELL, 1993; ver críticas em DEMELO et al., 1992; e as meta-análises de BRETT \& GOLDMAN, 1996; 1997) e de bottom-up : top-down (MCQUEEN et al., 1986) são os dois principais modelos conceituais de trabalho presentemente utilizados. Os efeitos máximos destes peixes e do zooplâncton herbívoro ocorrem geralmente em sistemas oligotróficos (MCQUEEN et al., 1986) ou mesotróficos (ELSER \& GOLDMAN, 1991) e a causa da importância crescente das algas não consumíveis, ou do balanço entre a predação pelos peixes zooplanctívoros e a pastagem pelo zooplâncton herbívoro (grazing), respectivamente. O fitoplâncton responde positivamente ao enriquecimento em nutrientes nos sistemas com redes tróficas impares (três níveis: fitoplâncton, zooplâncton e peixes planctívoros), mas não em sistemas com redes tróficas pares (dois níveis sem peixes, ou quatro níveis com peixes piscívoros).

$\mathrm{O}$ efeito do estoque de peixes planctívoros sobre a comunidade zooplanctônica já é bastante estudado (ARCIFA et al., 1986; LAZZARO, 1987, LAZZARO, 1991) e existe uma forte pressão destes peixes sobre as biomassas de algas (PIJANOWSKA \& PREJS, 1997; JEPPESEN et al., 1997). O efeito de piscívoros em um sistema apresenta forte relação ao estoque de planctívoros, fazendo com que este estoque se reduza drasticamente (MCQUENN, 1990; DEMELO et al., 1992; HAMBRIGHT, 1994). Alguns estudos confirmam que o impacto do estoque de peixes favorece as concentrações de clorofila através da excreção de nutrientes e da predação do zooplâncton (MCQUENN et. al., 1992; LAZZARO, 1997; DRENNER, 1998; STARLING, 1998). Em relação ao estoque de peixes piscívoros, muitos trabalhos não obtiveram sucesso (DEMELLO et al., 1992; MCQUENN et al., 1992), por diversos fatores que não foram levados em consideração, como a baixa densidade de estocagem (PERROW et al., 1997), mas em muitos trabalhos o efeito Top-Down foi observado (SHAPIRO et al., 1975; SHAPIRO \& WRIGHT, 1984; CARPENTER et al., 1985; PERSSON et al., 1988; MCQUEEN, 1990; FAAFENG \& BRABRAND, 1990; CARPENTER \& KITCHELL, 1993; PIJANOWSKA \& PREJS, 1997; SONDERGAARD et al., 1997; PREJS et al., 1997; MEIJER et al., 1999). 
CARPENTER et al. (1985) apresentaram uma revisão da teoria de cascata trófica e o controle de populações em lagos de água doce. O propósito deste trabalho foi sugerir que o conhecimento do funcionamento da cadeia alimentar pode ser usado para o manejo visando a ecologia de conservação. O incremento da piscivoria pode diminuir a densidade de planctívoros e, por conseqüência, o aumento da herbivoria (grazing) e depleções nas concentrações de clorofila. Os autores declararam que o aumento do estoque de piscívoros pode ser uma ferramenta para reabilitar lagos eutróficos. O conceito de cascata trófica com ligações entre limnologia e biologia pesqueira sugere uma alternativa biológica para o manejo de lago.

Segundo HAIRSTON \& HAIRSTON (1997), um padrão pode ser visto entre a eficiência de consumo de herbívoros em comunidades terrestres e aquáticas. Em sistemas aquáticos, o consumo por herbívoros é muito mais alto (32\%) quando comparado aos sistemas terrestres (3\%). Os autores comparam esta diferença ao papel que os predadores primários e secundários desempenham nos dois sistemas. Em lagos de água doce, predadores secundários são um componente importante, reduzindo os números de carnívoros primários. Isto reduz a pressão de predação nos herbívoros. Em comunidades terrestres, carnívoros secundários são quantitativamente uma parte sem importância da mortalidade de carnívoros primários. A predação primária é uma fonte principal de mortalidade dos herbívoros, permitindo um aumento dos produtores primários, evidenciando o efeito top down no controle de comunidades.

Os estudos de BRETT \& GOLDMAN (1996) comprovam a teoria de cascata trófica. Eles observaram que as manipulações das comunidades de peixes podem ser usadas para controlar biomassas de algas, porém estas relações são frágeis. Os autores mencionaram que o controle do fitoplâncton pelo manejo da cascata trófica (biomanipulação) pode acontecer em cerca de 60\% dos casos, e que a redução de espécies zooplanctívoras resultaria numa pequena redução na biomassa de fitoplâncton e, consequentemente, uma pequena melhoria na qualidade da água.

Segundo BELL et. al. (2003), o resultado de manipulações experimentais em ecologia deveria depender da duração dos experimentos. Os autores examinaram 90 trabalhos publicados sobre cascatas tróficas em comunidades de ecossistemas dulciaquícolas e perceberam diferenças nas forças dos elos das cascatas em relação ao tipo de local para a realização dos experimentos e em relação à duração dos experimentos. 
BORER et al. (2005) testaram hipóteses de cascata trófica utilizando uma revisão de 114 trabalhos com as relações tróficas indiretas testadas. A biomassa de predadores teve efeito direto na biomassa de plantas, tanto em ambientes terrestres como em aquáticos. Uma combinação de herbívoro e fatores metabólicos e taxonômicos do predador, explicou 31\% da relação de cascata entre todos os 114 estudos. Dentro de sistemas, $18 \%$ da relação de cascata foram explicadas com predador com características semelhantes à de herbívoro. Em todos os sistemas, as cascatas mais fortes aconteceram em associação de herbívoros invertebrados e predadores vertebrados endotérmicos. Estas associações são resultantes de uma combinação de verdadeiras diferenças biológicas entre espécies com diferentes exigências fisiológicas, e a influencia dos organismos estudados em sistemas diferentes.

JEPPESEN et al. (2000), ao estudarem a importância da presença de peixes em lagos rasos eutróficos, observaram que a retirada do estoque de ciprinídeos (roach) através do estoque de piscívoros (Perca fluviatilis) e da pesca seletiva com redes de emalhar ocasionaram uma diminuição na pressão sobre $\mathrm{o}$ zooplâncton, e consequentemente uma diminuição nas concentrações de fitoplâncton e clorofila em 71 lagos dinamarqueses. Com o aumento da transparência da água, a biomassa de macrófitas aquáticas aumentou nestes ambientes.

CARPENTER et al. (2001) testaram a hipótese de que os produtores primários responderiam mais fortemente ao enriquecimento por nutrientes, em lagos com três níveis tróficos (peixes planctívoros, zooplâncton herbívoro pequeno e fitoplâncton) e em lagos com um quarto nível trófico (além dos descritos acima, a presença de peixes piscívoros). O enriquecimento por nutriente deveria aumentar a concentração de clorofila e a produção primária, como também promover o aumento da captura de $\mathrm{CO}_{2}$ na atmosfera. Neste experimento os autores manipularam quatro lagos nos Estados Unidos, os quais foram enriquecidos com nutrientes comerciais $\left(\mathrm{NH}_{4} \mathrm{NO}_{3}\right.$ mais uréia + $\mathrm{H}_{3} \mathrm{PO}_{4}$ ), para alcançar a relação $\mathrm{N}: \mathrm{P}$ em 16:1. Antes da manipulação, os lagos apresentavam cadeias alimentares semelhantes, dominados pelos piscívoros largemouth bass (Micropterus salmoides), smallmouth bass (Micropterus dolomieu) e yellow perch (Perca flavescens). Os autores destacam que a resposta dos produtores foi mais forte em ambientes com três níveis tróficos do que em ambientes com quatro níveis tróficos.

BENNDORF et al. (2002) mencionam que o controle top-down para a clorofila acontece de acordo com as seguintes condições: (i) experiências de curta duração, (ii) lagos rasos com macrófitas e (iii) lagos fundos ligeiramente eutróficos ou mesotróficos. 
Outras experiências indicam que controle top-down pode ser improvável em condições de: (iv) eutrofia ou hipertrofia de lagos fundos, a menos que haja limitação severa de luz, e (v) todos os lagos caracterizaram através de limitação extrema de nutriente (lagos oligotróficos e ultraoligotróficos). Fatores importantes e responsáveis para o controle top-down sob as condições descritas em (i) e (iii) são as escalas de tempo que impedem o desenvolvimento lento do fitoplâncton; as profundidades rasas permitem que as macrófitas se tornem produtoras primárias dominantes (ii), e a biomanipulação induziu a redução de fósforo $(\mathrm{P})$ disponível para o fitoplâncton (iii).

BELL et al. (2003) realizaram experimentos de cascata trófica em tanques experimentais, durante um período de quatro anos. Os resultados desta pesquisa evidenciaram um maior desenvolvimento do fitoplâncton relacionado ao aumento da biomassa de piscívoros. Os autores salientam que grande parte dos estudos, visando o efeito de cascata trófica experimentais ou não, são desenvolvidos em pequena escala de tempo. Os autores salientam que o resultado de manipulações experimentais em ecologia deveria depender da duração da experiência, e este fator é determinante para se testar a hipótese de cascata trófica em lagos.

LATHROP et al. (2002) testaram a hipótese de cascata trófica com o propósito da biomanipulação. Estoques de peixes piscívoros foram introduzidos para incrementar as pescarias esportivas e reduzir a biomassa de zooplânctívoros, aumentando a pressão do macrozoplâncton (Daphnia) e consequentemente diminuindo a biomassa do fitoplâncton. O trabalho junto aos pescadores esportivos foi destacado, uma vez que a regulamentação da pesca foi determinante para a manutenção da população de alguns piscívoros. Os autores salientam que as populações de piscívoros poderiam apresentar maiores biomassas se houvessem medidas mais drásticas em relação à regulamentação da pesca esportiva.

MEHNER et al. (2005) compararam dados de variáveis tróficas (limnológicas) com a distribuição espacial e temporal dos peixes, zooplâncton e fitoplâncton. De acordo com a análise realizada (meta-análise), a distribuição dos níveis tróficos estudados foram correlacionados com a temperatura da água e a distribuição das concentrações de nutrientes. 


\subsection{Cascatas tróficas em ambientes tropicais e subtropicais}

Segundo LAZZARO et al. (2003), os açudes do semi-árido nordestino oferecem excelentes oportunidades para realizar comparações teóricas sobre a importância relativa do impacto das forças estruturadoras top-down e bottom-up nas interações peixe-plâncton em ambientes tropicais, entre o efeito da dominância da onivoria e da fraca piscivoria. Entretanto, a maioria dos açudes nunca foi estudada, exceto alguns açudes públicos de grande porte, principalmente os controlados pelo Departamento Nacional de Obras Contra a Seca (DNOCS), nos Estados do Ceará e da Paraíba. Foram raras as sínteses regionais sobre rendimento pesqueiro, hidroquímica e limnologia (por exemplo: DAVIES, 1972; GESTEIRA, 1978; SILVA, 1981; WRIGHT, 1981; DNOCS, 1990; MOLLE, 1991; GURGEL \& FERNANDO, 1994; PAIVA et al., 1994; BOUVY et al., 1998).

LAZZARO et al. (2003) salientam que para estabelecer generalidades, considera-se mais apropriado usar uma abordagem comparativa baseada em dados de climatologia, limnologia e comunidades de plâncton e peixes coletados no reservatório, já que estudos correlacionando todas estas variáveis são escassas (REGIER \& HENDERSON, 1980; QUIROS, 1990). Estudos com este tipo de abordagem podem proporcionar importantes implicações práticas e sociais para a limnologia preditiva (PETERS, 1986), ao manejo do rendimento pesqueiro (SCHLESINGER \& REGIER, 1982) e/ou a qualidade da água.

QUIRÓS \& BOVERI (1999), ao estudarem 31 reservatórios argentinos, demonstraram que nos ambientes em que o efeito do estoque de piscívoro não ocasionou uma depleção sobre os zooplanctívoros, a biomassa do fitoplâncton reduzia drasticamente. Os autores enfatizaram que a influência humana pode acarretar mudanças nas relações tróficas em lagos e reservatórios.

REJAS et al. (2005) avaliaram o efeito top-down e bottom-up em um lago de várzea boliviano. Os autores verificaram os dois tipos de efeitos na cascata trófica em experimentos em mesocosmos, sendo que o efeito destas relações variou entre os níveis tróficos. O efeito de peixes planctívoros não apresentou relação positiva com o zooplâncton, principalmente os cladóceros, e o fitoplâncton apresentou efeito bottomup. 


\subsection{Biomanipulação como ferramenta de manejo de cascatas tróficas: conceito e técnicas aplicadas}

O termo biomanipulação foi primeiramente utilizado por HRBÁČEK et al. (1961) e por SHAPIRO et al. (1975). O princípio deste método consiste na manipulação dos organismos aquáticos e da cadeia alimentar, visando a melhoria da qualidade. Pressões alimentares sobre o zooplâncton são efetuadas por peixes, de forma que espécies maiores de zooplâncton predominem, sendo assim capazes de manter a biomassa de fitoplâncton sob controle. Isto pode ser feito quando é baixo o número de peixes que se alimentam de zooplâncton. Em contrapartida, em reservatórios superpovoados os peixes crescem lentamente e devido a seu elevado número e pequeno tamanho (animais pequenos têm maior necessidade alimentar), as espécies maiores de zooplâncton são dizimadas, não sendo as menores capazes de controlar as algas eficientemente.

Em 1990, uma edição especial da Hydrobiology (Biomanipulation - Tool for Water Management, volume 200/2001) foi publicada e dedicada às pesquisas voltadas para biomanipulações em diferentes níveis tróficos em lagos e reservatórios.

A biomanipulação é uma técnica de ecotecnologia que pode ser aplicada para a recuperação de lagos nas regiões temperadas e tropicais (DE BERNARDI \& GIUSSANI, 2001), atuando no controle de poluição (eutrofização): (a) por meio de remoção biológica de nitrogênio e fósforo por macrófitas / biomanipulação; (b) através da disposição de resíduos sólidos (re-uso), utilizando o lodo orgânico como fertilizante agrícola; e (c) através da aquicultura (policultivo integrado), com o reaproveitamento de resíduos pelos próprios peixes / re-uso (MITSCH \& JORGENSEN, 1989). A aplicabilidade desta técnica em ambientes tropicais e subtropicais está na demanda de usos múltiplos de lagos urbanos para muitas atividades potencialmente conflitantes, como a elevada freqüência de eutrofização e superpopulação de peixes onívoros (tilápias) (exemplos do Lago Paranoá, Billings, Guarapiranga, Pampulha, Tapacurá, Jacarepaguá, etc.) e o elevado potencial de aplicação de técnicas complementares de manejo conjugando os benefícios ambientais com os sócio-econômicos.

Cadeias alimentares são controladas através das interações de cascata trófica, isto é, efeitos que se propagam aos diferentes elos da cadeia alimentar, e as biomassas dos organismos envolvidos são determinadas pela predação, dando origem às teorias 
bottom-up: top-down (MCQUEEN et al., 1986). Este conceito combina as influências do predador (o peixe é o topo da cadeia de alimentar, indo para baixo: top-down) e a disponibilidade do recurso (o recurso alimentar vem da base da cadeia, indo para cima: bottom-up), conforme apreentado na Figura 2.

Os primeiros experimentos com biomanipulação foram executados em lagos profundos (BENNDORF et al., 1984; CARPENTER \& KITCHELL, 1993), visando à remoção de peixes por meio da aplicação de rotenona ou da estocagem de peixes predadores (HENRICKSON et al., 1980; BENNDORF et al., 1984; 1988; SHAPIRO \& WRIGHT, 1984).

Na Holanda, a biomanipulação implica usualmente na redução substancial de peixes planctívoros e bentófagos em lagos de pouca profundidade. ROOS et al. (1995), realizaram experimentos no Lago Zuidlaardermeer, onde construíram cercados de madeira de $625 \mathrm{~m}^{2}$, observando os efeitos da redução de estoques de peixes no meio, na qualidade da água e nos organismos. MEIJER et al. (1999) revisaram trabalhos de biomanipulação em 18 lagos holandeses, sendo a eficiência deste método observada por meio do aumento da transparência da água em $90 \%$ dos casos. Vale ressaltar que o maior aumento desta variável ocorreu em lagos com alta redução de estoque de peixes.

Pode-se promover o desenvolvimento de populações de peixes capazes de controlar o desenvolvimento de zooplâncton e fitoplâncton de três maneiras (STRAŠKRABA \& TUNDISI, 2000):

1) Retirada temporária de populações atrofiadas por meio de envenenamento através de timbó (rotenona) ou por predadores;

2) Introdução contínua de peixes predadores e pesca com rede dos peixes forrageiros, colaboração com a pesca esportiva e emprego de métodos de pesca comercial;

3) Esvaziamento do reservatório durante os períodos de reprodução das espécies indesejáveis de peixes.

KASPRZAK (2001), em uma extensiva revisão na literatura, classificou os sucessos e os fracassos da biomanipulação, sendo os mais relevantes:

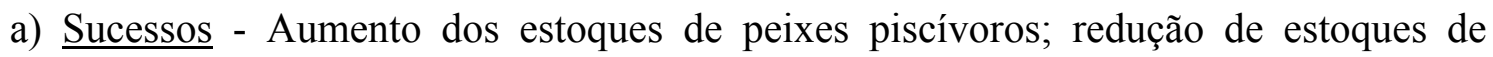
peixes planctívoros; incremento do zooplâncton, principalmente as espécies de Daphnia, e aumento de seu tamanho médio; aumento da herbivoria realizada pelo zooplâncton; melhoria no desenvolvimento dos macrozoobentos; redução na biomassa do fitoplâncton; mudança estrutural do fitoplâncton; redução da produção primária planctônica; aumento da biomassa de macrófitas em lagos rasos; aumento 
na transparência das águas; redução da concentração total de fósforo; limitação da amplitude de variação do ritmo diurno da concentração de oxigênio e pH.

b) Fracassos e problemas - A estabilização de uma população de peixes piscívoros é difícil e requer muito tempo. Às vezes torna-se difícil controlar a população de peixes planctívoros, que sempre tende a estabelecer estoques elevados. Com exceção do envenenamento de toda a comunidade, a remoção manual de espécies de peixes que se alimentam de zooplâncton e/ou pela introdução de espécies predadoras, pode, por vezes, ser fraca demais para provocar reações consideráveis. O volume de peixes planctívoros a ser removido depende em grande parte das espécies e da composição por tamanho da comunidade de peixes. As populações de Daphnia spp dificilmente ficam estáveis, sendo ameaçadas de um lado por peixes planctófagos e por outro, sofrendo por falta de alimentos quando ocorrer excesso de biomanipulação. Por vezes é difícil separar os mecanismos Top-down e Bottom-up, pois as interações dentro da cadeia alimentar são abafadas, estocasticamente perturbadas e influenciadas por mudanças sazonais. Devido aos diferentes tempos de reposição dos organismos, o restabelecimento de um novo estado de equilíbrio pode levar anos. Normalmente o fitoplâncton é considerado um grupo homogêneo, suas diferenças somente são consideradas no que diz respeito a seu valor nutricional para o zooplâncton. À medida que aumentam as pressões sobre o fitoplâncton, essa comunidade tende a desenvolver uma série de mecanismos de defesa. Com uma concentração crescente de fósforo, diminuem as chances de sucesso mediante a biomanipulação; raramente considera-se o papel do protozooplâncton e das bactérias.

DRENNER \& HAMBRIGHT (1999) avaliaram o sucesso de projetos de biomanipulação relacionados à melhoria da qualidade de água em lagos e reservatórios eutróficos de regiões temperadas. Foram revisados 41 trabalhos experimentais envolvendo a redução de peixes zooplanctívoros e bentófagos em 39 lagos. As experiências foram divididas em 5 categorias: (1) estoque de piscívoros; (2) estoque de piscívoros com remoção parcial de peixes; (3) remoção parcial de peixes; (4) eliminação de peixes e (5) eliminação de peixes, seguido de estocagem. Foi observado que, dentre as 5 experiências executadas, as mais apropriadas foram (2) e(3).

REYNOLDS (1994) acredita que não seja possível fazer uma lista de fatores positivos e negativos na manipulação de ecossistemas aquáticos, mas apresenta algumas características do corpo de água para que a biomanipulação tenha sucesso, como: (1) lagos pequenos, menores que 4 ha; (2) lagos rasos, com profundidade máxima menor 
que $4 \mathrm{~m}$ e profundidade média de $1 \mathrm{~m}$; (3) tempo de retenção igual e menor que 30 dias; (4) mais que a metade da superfície do lago deve suportar uma cobertura da superfície de macrófitas; (5) algumas medidas devem ser tomadas para promover o crescimento de macrófitas; (6) os lagos pré-manipulados não devem ser dominados por Oscilatoria ou qualquer outro desenvolvimento de algas azuis. O lago deve ser dominado por Chlorococcales e/ou pequenas diatomáceas e/ou flagelados incluindo Cryptomonas; (7) deve haver peixes, mas a população deve ser controlada. Provavelmente é melhor retirar os peixes e depois reestocar peixes herbívoros em níveis ideais; (8) não havendo a ocorrência da população natural de Daphnia, deve-se introduzir D. magna.

A pesca seletiva e a introdução de peixes constituem ferramentas para a biomanipulação. Na maioria dos experimentos de manipulação de cadeia alimentar, o peixe é o elemento manipulado (GOPHEN, 1995).

MCQUEEN (1998) revisou estudos com biomanipulação e a classificou em seis categorias:

a) Adição de peixes planctívoros em pequenos lagos ou tanques: aumento da densidade de algas, porque aumenta a bioturbação, e sofre redução da biomassa de zooplâncton e de macrófitas.

b) Adição de planctívoros em lagos profundos e estratificados: resulta na redução da pressão do zooplâncton sobre o fitoplâncton, aumentando assim a densidade de algas.

c) Remoção de planctívoros em pequenos lagos ou tanques: tende a estabilizar a bioturbação, aumentando a cobertura de macrófitas e também a pressão do zooplâncton sobre o fitoplâncton. Todavia, estudos de longo prazo sugerem que o sucesso inicial de manipulação pode ser objeto de deterioração devido à substituição de espécies de macrófitas, reinvasão dos planctívoros-bentívoros, e substituição de espécies de algas.

d) Remoção de planctívoros em lagos profundos e estratificados: freqüentemente resulta em reduções do estoque algal permanente, dando tempo suficiente para que as algas não consumidas dominem a biomassa total de algas retornando às condições pré-manipuladas.

e) Adição de piscívoros em pequenos lagos ou tanques: apresentam sucesso enquanto a biomassa de planctívoros-bentívoros permanece baixa. O sucesso é maior quando a comunidade de macrófitas permanece intacta. Todavia, estudos longos sugerem que as densidades de piscívoros freqüentemente declinam e os mesmos parecem ser incapazes de manter a comunidade de planctívoro-bentívoro em baixos níveis. 
f) Adição de piscívoros em lagos profundos e estratificados: resulta em períodos curtos de controle de algas. A substituição de espécies por predadores invertebrados, a proliferação de algas que não são consumidas e mudanças na reciclagem de nutrientes freqüentemente produzem uma nova reestruturação na cadeia alimentar, capaz de sustentar biomassas de algas diferentes daquelas observadas durante os períodos de pré-manipulação.

A aplicação de técnicas de biomanipulação é mais difícil nos trópicos e nas regiões subtropicais devido à alta diversidade de peixes, à grande diferença espacial na composição das espécies, à existência de peixes onívoros e às cadeias alimentares mais complexas, conforme observado por STEIN et al. (1995) em reservatórios no sul dos EUA.

LAZZARRO (1997) salienta que as cadeias alimentares de um ecossistema tropical apresentam várias características distintas em relação aos ecossistemas temperados como: (a) peixes carnívoros mais generalistas, substituindo os estritamente piscívoros; (b) predominância do onívoro no lugar do zooplanctívoro; (c) ausência de Daphnia, com dominância de microzooplâncton (rotíferos e pequenos cladóceros); (d) elevada proporção de alga de grande tamanho, pouco sujeitas a herbivoria pelo zooplâncton. A fraca relação fito-zooplâncton em sistemas tropicais ou subtropicais favorece o processo de detritivoria na cadeia alimentar e de onivoria pelos peixes planctívoros, explicando assim a complexidade dos ecossistemas tropicais (Figura 3).

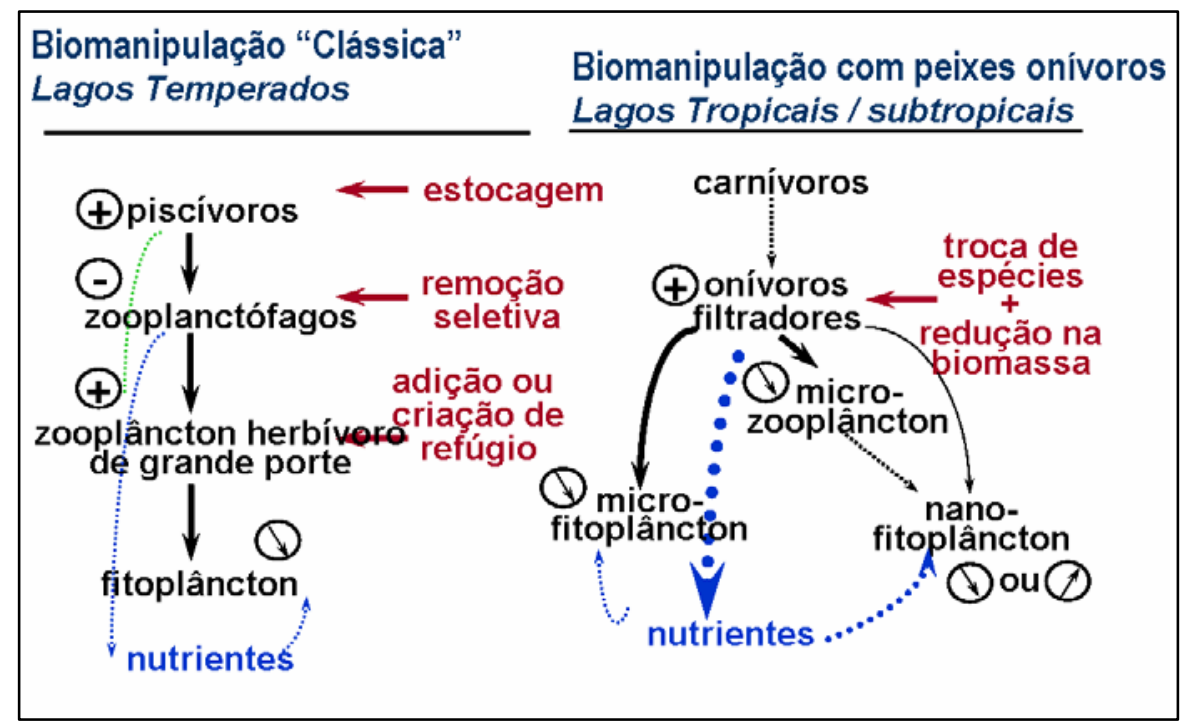

Figura 3: Comparação entre a complexidade das interações nos ambientes temperados e tropicais (Fonte: STARLING \& LAZZARO, 2000). 
Trabalhos realizados em Israel e no Brasil obtiveram sucesso utilizando carpa prateada, espécie que se alimenta diretamente de grandes colônias de fitoplâncton (LEVENTER \& TELTSCH, 1990; STARLING, 1993). GOPHEN (1995) verificou que a introdução de carpa prateada afetou outras espécies em Israel, e nos trópicos começam a surgir os primeiros resultados envolvendo testes experimentais com peixes zooplanctófagos (ARCIFA et al., 1986; ROCHE et al., 1993) ou iniciativas de manejo envolvendo peixes onívoros (STARLING, 1993, ARCIFA et al., 1995; STARLING \& LAZZARO, 1997), sendo ainda necessário um maior conhecimento da cadeia alimentar dos ambientes.

A vantagem do método de biomanipulação, além do seu baixo custo, é ser inteiramente natural, não utilizando equipamentos nem produtos químicos, mas somente recursos biológicos, além de combinar as necessidades dos peixes com indicativos da boa qualidade da água. A única limitação se refere à necessidade de um controle das populações ictíicas no sentido de evitar uma elevada biomassa no ambiente. A pesca esportiva tem maior atuação sobre a população de peixes predadores do que sobre outras que se alimentam de zooplâncton, contribuindo para o desequilíbrio da cadeia trófica. Nesse sentido, o controle citado atuaria nesta pesca, de forma a diminuir o impacto desta atividade sobre a qualidade final da água.

\subsection{Estratégias de manejo de peixes baseadas na estocagem de peixes predadores}

O papel desempenhado pelos peixes no ecossistema de um lago ou um reservatório pode ser considerado importante por três motivos (GULATI, 2001): (a) predação do zooplâncton; (b) contribuição à dinâmica dos nutrientes; (c) ressuspensão do sedimento do fundo. São necessários, portanto, planos de gerenciamento detalhados para ecossistemas onde os recursos pesqueiros são superexplotados ou em que deva ser recuperado devido a processos de eutrofização.

Dentre as várias técnicas de manejo ecológico dos ecossistemas lacustres para redução do seu estado trófico, a introdução de espécies piscívoras já é bastante difundida em regiões temperadas, como já foi mencionado por HRBÁČEK et al. (1961), SHAPIRO et al. (1975), SHAPIRO \& WRIGHT (1984), CARPENTER et al. 
(1985) e MEIJER et al. (1999). O manejo dos peixes objetiva reduzir as espécies zooplanctófagas, predadoras visuais, e aumentar as populações do zooplâncton herbívoro de grande porte (Daphnia). Nos trópicos e subtrópicos, a abordagem alternativa de controle dos nutrientes liberados pelos peixes onívoros e/ou uso direto de peixes fitoplanctófagos filtradores para consumo das algas apresenta-se como a técnica mais difundida (LAZZARO, 1987; CRISMAN \& BEAVER, 1990; STARLING \& ROCHA, 1990; STARLING, 1998).

Embora a abundância do fitoplâncton em lagos seja controlada pela disponibilidade de nutrientes, a hipótese de cascata trófica prediz que a variabilidade da abundância do fitoplâncton pode ser atribuída à abundância de peixes piscívoros, que volta a afetar a abundância de peixes planctívoros e o zooplâncton (CARPENTER et al., 1985). A regulação do fitoplâncton com a abundância de peixes piscívoros foi muitas vezes citada como uma forte evidência de hipótese de cascata trófica e um forte efeito Top-down em lagos (MCQUEEN et al., 1986), mas evidências experimentais mostram que a relação piscívoros/fitoplâncton não apresentou resultados satisfatórios (DEMELO et al., 1992), devido à combinação de outros fatores não considerados nos resultados, como já mencionado anteriormente.

No lago Paranoá (Brasília-DF), o tucunaré é um peixe predador que apresenta melhor controle sobre as presas (tilápias, Oreochromis niloticus), com resultados bastante expressivos no que se refere ao controle desta biomassa (RIBEIRO FILHO, 2002). Os estoques de tilápias, porém, não são controlados pela presença do predador e de acordo com as estimativas pesqueiras realizadas por LAZZARO et al. (1998) e LEBOURGES-DHAUSSY et al. (1998), o estoque de tilápias foi mais abundante nos braços mais eutróficos, ao contrário da abundância de tucunaré, com maiores abundâncias observadas nas regiões menos poluídas (mesotróficas). RIBEIRO FILHO (1999), analisando o funcionamento da estruturas tróficas dos predadores do Lago Paranoá, observou que a presa mais abundante nos estômagos do tucunaré foi a planaltina (Planaltina sp.), perfazendo cerca de 50\% dos estômagos analisados, enquanto a tilápia esteve presente em $28 \%$ dos estômagos. Estes resultados sugerem realmente que o tucunaré e a tilápia exploram regiões diferentes no lago, não havendo necessidade de grandes deslocamentos pelos predadores para localização de alimento e captura.

LAZZARO (1997) e LAZZARO et al. (2003) salientam que as cadeias alimentares de um ecossistema tropical apresentam várias características distintas em 
relação aos ecossistemas temperados, e que a fraca relação fito-zooplâncton em sistemas tropicais ou subtropicais favorece o processo de detritivoria na cadeia alimentar e de onivoria pelos peixes planctófagos, explicando assim a complexidade dos ecossistemas tropicais, e mostrando que o predador apresenta hábitos extremamente generalistas em relação aos piscívoros de ambientes temperados.

LAZZARO et al. (2003), com base em estudos em reservatórios da região Nordeste do Brasil, caracterizaram o efeito do estoque de planctívoros e onívoros na cadeia alimentar:

a) Efeitos de peixes planctívoros em cadeias alimentares: os peixes planctívoros podem ser classificados em dois tipos, de acordo com o comportamento alimentar, podendo exercer diferentes impactos sobre o plâncton. Uma coexistência pode obscurecer previsões globais de impactos de planctívoros. A biomassa de peixes planctívoros estocada é mais importante do que o tipo de planctívoro para a regulação das comunidades de plâncton, qualidade de água e estado trófico. Os zooplanctívoros visuais têm fortes efeitos sobre o zooplâncton, mas efeitos variáveis no fitoplâncton, ocorrendo em baixas biomassas $(<100 \mathrm{~kg} / \mathrm{ha})$ em condições oligo/ mesotróficas. Onívoros filtradores, com alta taxa de crescimento e baixa vulnerabilidade a predadores, geralmente alcançam altas densidades $(>1000 \mathrm{~kg} / \mathrm{ha}) \mathrm{e}$ dominam em condições eutróficas. Nestas condições exercem ainda fortes efeitos sobre o fitoplâncton, agindo como planctívoros facultativos e oportunistas. Os onívoros promovem um aumento na densidade do fitoplâncton através de complexos mecanismos, dentre os quais a maior contribuição para a regeneração e reciclagem de nutrientes na coluna de água, remoção seletiva de zooplâncton de maior porte, principalmente cladóceros, e regulação da razão nutriente-fitoplâncton, regulados pelo tamanho, não pela biomassa. Microcarnívoros, incluindo espécies de zooplanctívoros facultativos, habitam áreas litorais protegidas para evitar predadores, ao passo que onívoros que dominam áreas com maior turbidez e sistemas eutróficos, têm hábitos mais pelágicos e/ou bentônicos. Os efeitos de cascata trófica de peixes sobre o fitoplâncton são mais intensos em quatro níveis de sistemas tróficos: piscívoros, planctívoros, zooplâncton (herbívoros grandes, principalmente Cladóceros) e fitoplâncton, resultando em significativas relações positivas entre os peixes planctívoros e a biomassa de fitoplâncton ou clorofila. De modo oposto, quando os elos entre os níveis cascata trófica são fracos ou as relações não são 
lineares, pode-se esperar que biomassas de peixes e fitoplâncton (clorofila) sejam desconexas, conduzindo para relações imprevisíveis.

b) Efeitos da onivoria e detritivoria em cadeias alimentares: a onivoria, associada à detritivoria, pode ocasionalmente gerar efeitos Top-down, dando a aparência de cascatas tróficas lineares simples, e envolver ainda vários mecanismos análogos para competição aparente. Eles incluem efeitos como a introdução de detritívoros na cadeia de herbivoria (grazing), promovendo a reciclagem interna dos nutrientes pelos organismos, via excreção e ingestão, e ligações tróficas de acordo com os tipos de habitat.

De acordo com LAZZARO (1997), é raro encontrar uma espécie de predador que se alimente estritamente de uma espécie de presa em ambientes tropicais, devido a alta diversidade de presas e pelo hábito dos predadores. Por isso, no caso do Lago Paranoá, a utilização de outras formas de manejo pode ter mais sucesso no controle da tilápia no ambiente (RIBEIRO FILHO, 2002).

Segundo LAZZARO et al. (2003), o aumento da biomassa de macrocarnívoros é uma prioridade para limitar o sucesso do recrutamento de planctívoros facultativos, particularmente espécies altamente prolíferas, como tilápia, limitando assim o aumento da eutrofização. Portanto, não unicamente as variáveis físicas e químicas da água, mas a fauna de peixes, também deve ser simultaneamente monitorada através de longos programas contribuindo para as práticas de estocagem de peixes.

Estas sugestões são consoantes com as de QUIRÓS (1998) para lagos e reservatórios argentinos. A re-estocagem de piscívoros não melhora unicamente a qualidade da água, mas também pode sustentar uma atividade pesqueira lucrativa. A combinação de espécies deveria ser otimizada, conforme mencionado por PAIVA et al. (1994), que sugeriram que a captura máxima comercial pode ocorrer em reservatórios com duas espécies de predadores. 


\section{HIPÓTESE}

Esta pesquisa baseia-se na hipótese de que as relações tróficas em cascata, particularmente relacionadas aos efeitos bottom-up e top-down e amplamente discutidas para ecossistemas aquáticos localizados em regiões temperadas, podem ser encontradas no Reservatório de Itaipu, um sistema inserido em região subtropical.

\section{OBJETIVOS}

Avaliar as características limnológicas do Reservatório de Itaipu (corpo central e braços da margem esquerda do reservatório), por meio da análise das variáveis físicas, químicas e biológicas, tendo em vista os usos múltiplos do reservatório, no período de 1999 a 2004;

$\checkmark \quad$ Analisar a evolução dos níveis tróficos do reservatório, incluindo os seus braços da margem esquerda;

$\checkmark \quad$ Caracterizar as redes tróficas e as relações entre a biomassa relativa de peixes, plâncton e características limnologicas do reservatório de Itaipu.

$\checkmark \quad$ Fazer recomendações, usando estes conhecimentos, para melhorar o rendimento pesqueiro e/ou a qualidade da água. 


\section{MATERIAL E MÉTODOS}

\subsection{Caracterização da área de estudo}

O rio Paraná é o décimo rio mais longo do planeta $(4.695 \mathrm{~km})$, sendo considerado o mais importante do sistema hidrológico da Bacia do Prata (BORGHETTI et al., 1988). É formado pela confluência dos rios Grande e Parnaíba (no centro-sul do Brasil), desaguando no rio da Prata, ao norte da Argentina (AGOSTINHO \& GOMES, 2005). A bacia do rio Paraná é responsável por mais de $70 \%$ da produção de energia hidrelétrica do Brasil, concentra a maior densidade populacional da América do Sul e compreende outros rios de grande importância, como os rios Grande, Tietê, Parnaíba, Paranapanema e Iguaçu, nos quais foram construídas cerca de 130 barragens (Figura 4).

O reservatório de Itaipu (Figura 5), concluído em outubro de 1982, localiza-se na divisa Brasil-Paraguai, entre os paralelos de $24^{\circ} 05^{\prime}$ e $25^{\circ} 33^{\prime}$ de latitude Sul e entre os meridianos $54^{\circ} 00^{\prime}$ e $54^{\circ} 37^{\prime}$ de longitude Oeste (Grw). Apresenta uma superfície de $1.350 \mathrm{~km}^{2}$ em sua cota média de operação $(220 \mathrm{~m})$ e $1.460 \mathrm{~km}^{2}$ na cota máxima $(223 \mathrm{~m})$, sendo $625 \mathrm{~km}^{2}$ no Brasil e $835 \mathrm{~km}^{2}$ no Paraguai. Estende-se por $151 \mathrm{~km}(170 \mathrm{~km}$ na quota máxima normal) e separa as cidades de Guairá - Salto del Guayrá e também Foz do Iguaçu- Ciudad de Leste (AGOSTINHO et al., 1999).

No Brasil, o alagamento envolveu terras do Estado do Paraná (municípios de Guaíra, Terra Roxa, Marechal Cândido Rondon, Santa Helena, Matelândia, Medianeira, São Miguel do Iguaçu e Foz do Iguaçu) e no Paraguai, os departamentos de Canindeyu (distrito de Salto del Guayrá) e Alto Paraná (distrito de Hernandaria). Cabe ressaltar que, após a formação do reservatório, a divisão política desses municípios foi alterada, com o surgimento de quatro novos municípios (AGOSTINHO et al., 1999). 


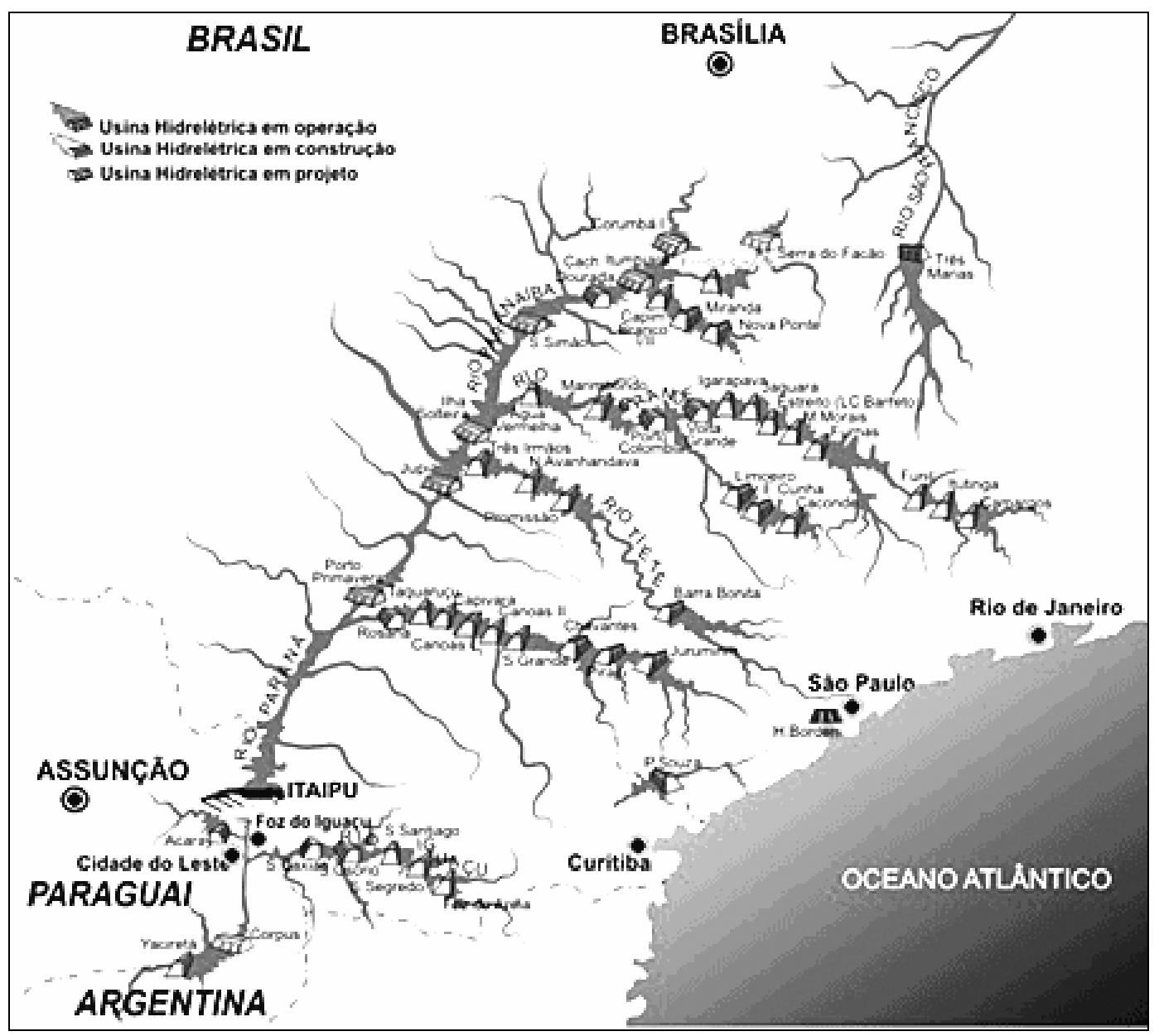

Figura 4: Bacia do rio Paraná, com distribuição dos reservatórios (Fonte: Itaipu Binacional, 2006).

A bacia de drenagem do reservatório de Itaipu envolve quase $10 \%$ do território brasileiro $\left(820.000 \mathrm{~km}^{2}\right)$, estando o trecho represado assentado sobre espessos derrames basálticos (Triássico) recobertos com um solo marrom-avermelhado conhecido como "terra rocha estruturada" e "latossolo roxo", de alta fertilidade natural. No trecho represado por esse reservatório, o rio Paraná corria encaixado em uma fenda tectônica estreita, com paredes de mais de 100m de altura (MAACK, 1981 apud AGOSTINHO et al., $\left.1999^{1}\right)$.

Acima do reservatório, o rio Paraná apresenta uma ampla planície aluvial, especialmente em sua margem direita, que exibe um canal anastomosado (braided) com reduzida declividade e inúmeras ilhas (ex.: Ilha Grande, com extensão de $80 \mathrm{~km}$ ) e barras longitudinais e transversais formadas pelo acúmulo de sedimentos. Nesse trecho,

\footnotetext{
${ }^{1}$ MAACK, R. 1981. Geografia física do Estado do Paraná. Rio de Janeiro: J. Olympio. 450p. apud AGOSTINHO et al. (1999). A pesca no reservatório de Itaipu: aspectos sócio-econômicos e impactos do represamento. In: HENRY, R. (Ed.). Ecologia de reservatórios: estrutura, função e aspectos sociais. FUNBBIO/FAPESP 800p.
} 
o rio ostenta intrincada anastomose com os canais e lagoas da planície. Os derrames basálticos nessa região são cobertos pelo arenito de Caiuá (sandstone) do Jurássico, com baixa fertilidade natural e amplamente suscetível à erosão (AGOSTINHO et al., 1999).

A região do reservatório de Itaipu, em seu lado esquerdo, foi coberta por uma floresta pluvial subtropical que cobria os vales dos rios do Sul do Brasil em altitudes inferiores a 500m. Até 1960, essa vegetação cobria cerca de $75 \%$ do extremo oeste do Estado do Paraná, sendo essa cobertura reduzida, em menos de 20 anos, para aproximadamente 8,6\% (KOHLLEPP, 1987 apud AGOSTINHO et al. 1999²). Em 1982, quando o reservatório foi fechado, nenhuma área arborizada de grandes dimensões foi alagada em território paranaense. No lado paraguaio, entretanto, o reservatório cobriu grandes áreas florestadas, com remanescentes consideráveis ainda hoje ocupando grandes extensões na margem direita e transformados em áreas de preservação permanente (AGOSTINHO et al., 1997a).

A produção de energia é o principal uso do reservatório de Itaipu, sendo essa a motivação primordial de sua construção. Entretanto, outros usos secundários são atualmente vigentes, destacando-se (i) a navegação, facilitada pelo afogamento dos saltos de Sete Quedas (Guaíra), (ii) a recreação e o turismo, exercidos essencialmente em cinco praias artificiais construídas em suas margens, (iii) o abastecimento de água para as cidades e a irrigação dos minifúndios e (iv) a pesca profissional (AGOSTINHO et al., 1997a).

Com profundidade média de $22 \mathrm{~m}$, podendo alcançar $170 \mathrm{~m}$ nas proximidades da barragem, o reservatório de Itaipu acumula, em volume máximo normal, $29109 \mathrm{~m}^{3} \mathrm{de}$ água. O tempo de residência no canal principal é de 29 dias e a velocidade da água pode alcançar $0,6 \mathrm{~m} / \mathrm{s}$. O tempo médio de residência é, no entanto, de 40 dias. Opera com uma variação de nível máxima anual de 0,6m (Itaipu Binacional, 2006).

\footnotetext{
${ }^{2}$ KOHLHEPP, G. 1987. Itaipu: basic geopoplit and energy situation; socio-economic and ecological consequences of the Itaipu dam and reservoir on the Rio Paraná (Brazil/Paraguay); a publ. Of Dt.Zentrum fur Entwicklungstechonogien - GATE In: Dt. Ges.fur Zusammenarbeit (GTZ) GmbH/Gerd Kohlhepp Braunschweig; Wiesbaden : Vieweg. 100p. apud AGOSTINHO et al. (1999). A pesca no reservatório de Itaipu: aspectos sócio-econômicos e impactos do represamento. In: HENRY, R. (Ed.). Ecologia de reservatórios: estrutura, função e aspectos sociais. FUNBBIO/FAPESP 800p.
} 


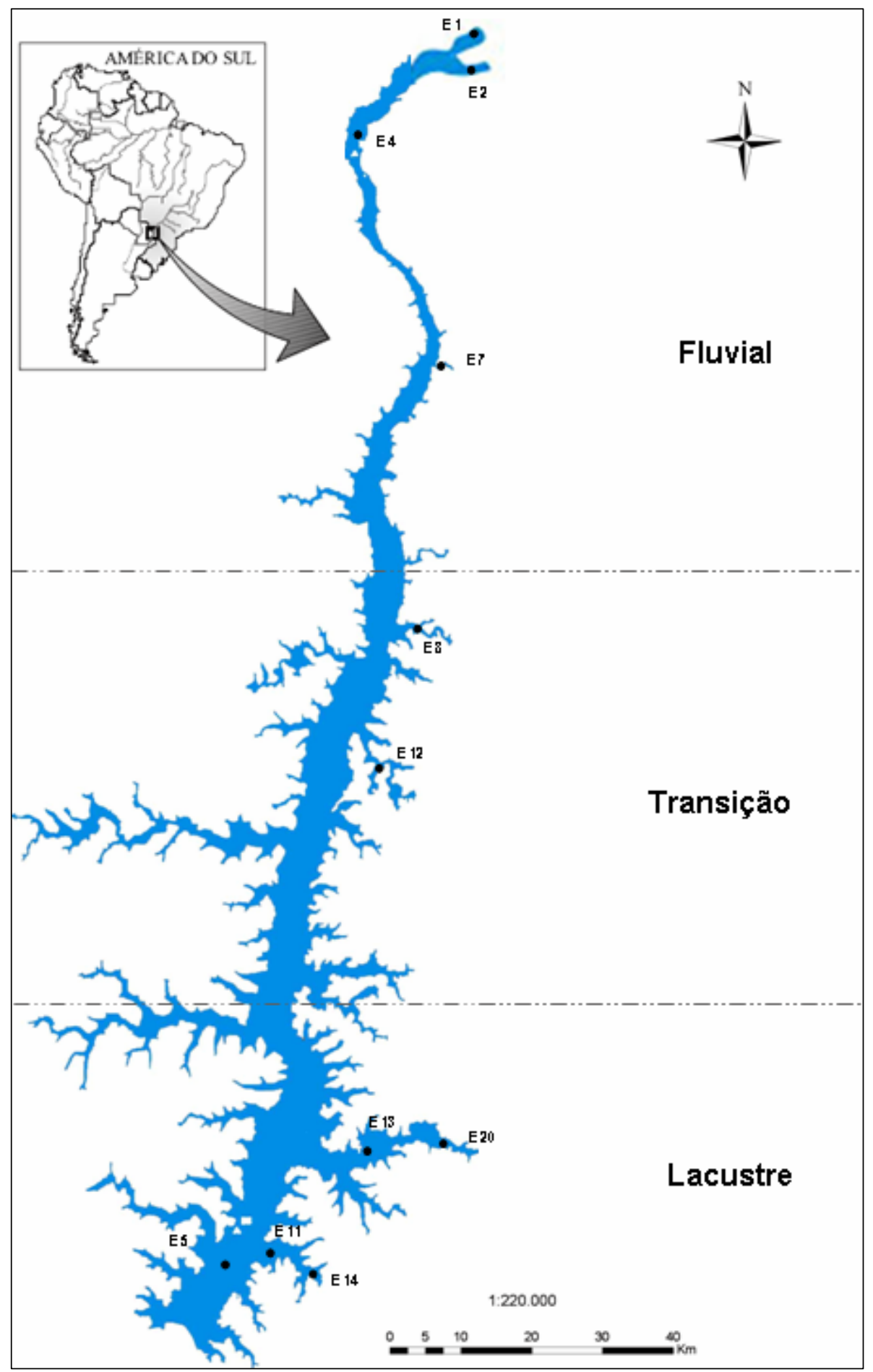

Figura 5: Morfometria e locais de amostragem no reservatório de Itaipu, com as zonas fluvial, transição e lacustre, adotados no programa de monitoramento.

Tendo como base o índice de estado trófico de Carlson (fósforo e clorofila), esse reservatório foi classificado como mesotrófico, podendo ser registradas áreas eutrofizadas em seus braços em determinados períodos do ano. Entre os fatores que limitam sua produção primária, destacam-se as baixas concentrações de fósforo no inverno e na primavera $(<0,010 \mathrm{mg} / \mathrm{L})$, a turbidez abiótica (argila) durante o verão e a 
baixa relação $Z_{\text {eu }} / Z_{\max }$ (ANDRADE et al., 1988 apud AGOSTINHO et al. 1999³). Apresenta um ciclo de estratificação térmica anual em seu corpo principal (primaveraverão), o que lhe confere características de lago monomítico quente, além de processos de estratificação diária em seus braços. BRUNKOW et al. (1988) apud AGOSTINHO et al. $\left(1999^{4}\right)$ atribuem os processos de estratificação nesse reservatório (i) à tomada da água na barragem, próximo à superfície $(20 \mathrm{~m})$; (ii) à grande profundidade verificada em sua calha principal; (iii) à grande variação anual da temperatura da água do rio Paraná $\left(14^{\circ} \mathrm{C}\right)$, trazendo àguas mais frias durante o outono e o inverno (entrada inferior e circulação) e quentes no verão (entradas superficiais e estratificação). Embora completamente oxigenado no período de circulação da água, apresenta bolsões anóxicos no metalímnio e baixas concentrações de oxigênio no hipolímnio na época de estratificação. O fato de as águas do rio Paraná terem curso no sentido norte-sul e serem incorporadas à camada superior do reservatório na primavera e no verão (zona eufótica), embora leve a depleções das concentrações de oxigênio no metalímnio, deve contribuir de modo decisivo para sua produtividade (AGOSTINHO et al., 1999).

A assembléia de peixes do reservatório de Itaipu e de sua área de influência é composta por 114 espécies que se apresentaram fortemente agregadas em todos os ambientes. As espécies dominantes variam com o tipo de ambiente, pois este é um fator que contribui para a estruturação dessa assembléia (RELATÓRIO ANUAL ITAIPU BINACIONAL). Os padrões de riqueza e diversidade também variam de acordo com o tipo de ambiente, sendo as maiores diversidades e riquezas encontradas na zona litorânea do reservatório, o que ressalta a importância dessas áreas para a manutenção da diversidade ictiofaunística (AGOSTINHO et al., 1997b).

\footnotetext{
${ }^{3}$ ANDRADE, L.F.; BRUNKOW, R.F.; XAVIER, C.F.; DOMINGUES, L.L. 1988. Fitoplâncton e características físico-químicas do reservatório de Itaipu, Paraná - BR. In: TUNDISI, J.G. (Ed.). Limnologia e Manejo de Represas. São Carlos : EESC - USP/CRHEA/ACIESP. v.1, t.1, p.205-268. (Série Monografias em Limnologia) apud AGOSTINHO et al. (1999). A pesca no reservatório de Itaipu: aspectos sócio-econômicos e impactos do represamento. In: HENRY, R. (Ed.). Ecologia de reservatórios: estrutura, função e aspectos sociais. FUNBBIO/FAPESP 800p.

${ }^{4}$ BRUNKOW, R.F.; ANDRADE, L.F.; XAVIER, C.F. 1988. Processo de estratificação térmica e de oxigênio dissolvido no reservatório de Itaipu, Paraná-BR. In: TUNDISI, J.G. (Ed.). Limnologia e Manejo de Represas. São Carlos: EESC-USP/CRHEA/ACIESP. v.1, t.1, p.269-298 apud AGOSTINHO et al. (1999). A pesca no reservatório de Itaipu: aspectos sócio-econômicos e impactos do represamento. In: HENRY, R. (Ed.). Ecologia de reservatórios: estrutura, função e aspectos sociais. FUNBBIO/FAPESP 800p.
} 


\subsection{Caracterização das estações de amostragem}

Para o estabelecimento da localização das estações de amostragem considerouse a compartimentalização horizontal/longitudinal do reservatório de Itaipu, que se apresenta com três regiões caracteristicas, ao longo do corpo central do reservatório (AGOSTINHO et al., 1997b; AGOSTINHO et al., 1999; IAP, 2003; OLIVEIRA et al., 2005):

- região lótica: localizada no início do reservatório, ou riverine zone;

- região de transição: entre as fases lótica e lêntica; e

- região lêntica: denominada de "região lacustre", onde o reservatório é normalmente mais largo e profundo.

Além disso, o reservatório de Itaipu apresenta forma dendrítica, ou seja, além do seu corpo central, possui ramificações em suas margens, denominadas braços do reservatório, que representam sistemas quase independentes do corpo central e com características próprias. Este tipo de compartimentalização que ocorre em reservatórios foi descrito por TUNDISI (1986).

Em função desta compartimentalização, foi estabelecida uma rede de monitoramento de qualidade de água, totalizando doze estações de amostragem, cuja localização encontra-se na Tabela 2 e Figura 5.

Tabela 2: Localização das estações de amostragem no reservatório de Itaipu.

\begin{tabular}{cl}
\hline $\begin{array}{c}\text { ESTAÇÕES DE } \\
\text { AMOSTRAGEM }\end{array}$ & LOCALIZAÇÃO \\
\hline E1 & $\begin{array}{l}\text { Canal direito do rio Paraná, a montante do Reservatório de } \\
\text { Itaipu, em Guaíra. }\end{array}$ \\
\hline E2 & $\begin{array}{l}\text { Canal esquerdo do rio Paraná, a montante do Reservatório de } \\
\text { Itaipu, em Guaíra. }\end{array}$ \\
\hline E4 & $\begin{array}{l}\text { Corpo central do Reservatório de Itaipu, a jusante de Guaíra, } \\
\text { próximo a Oliveira Castro. }\end{array}$ \\
\hline E5 & $\begin{array}{l}\text { Corpo central do Reservatório de Itaipu, 15 Km a montante da } \\
\text { barragem. }\end{array}$ \\
\hline E6 & Rio Paraná, 4 Km a jusante da barragem. \\
\hline E7 & Braço do Reservatório de Itaipu, formado pelo Arroio Guaçu. \\
\hline E8 & $\begin{array}{l}\text { Braço do Reservatório de Itaipu, formado pelo rio São } \\
\text { Francisco Verdadeiro. }\end{array}$ \\
\hline E11 & Braço do Reservatório de Itaipu, formado pelo rio Passo Cue. \\
\hline E12 & $\begin{array}{l}\text { Braço do Reservatório de Itaipu, formado pelo rio São } \\
\text { Francisco Falso. }\end{array}$ \\
\hline E13 & Braço do Reservatório de Itaipu, formado pelo rio Ocoí. \\
\hline E14 & Braço do Reservatório de Itaipu, formado pelo rio Passo Cue. \\
\hline E20 & Braço do Reservatório de Itaipu, formado pelo rio Ocoí. \\
\hline
\end{tabular}




\subsection{Aquisiçãa dos dados}

Os dados analisados neste trabalho foram gentilmente cedidos pela Itaipu Binacional. As análises limnológicas, incluindo as variáveis físicas e químicas da água, fitoplâncton e zooplâncton, foram efetuadas pelo Instituto Ambiental do Paraná (IAP) e as informações sobre os levantamentos do estoque pesqueiro são provenientes dos estudos desenvolvidos pelo Núcleo de Pesquisa em Limnologia, Ictiologia e Aqüicultura (NUPELIA/ UEM).

De acordo com os relatórios apresentados pelo IAP, as coletas de água para determinação das variáveis físicas, químicas e biológicas foram trimestrais (fevereiro, maio, agosto e novembro), ocorrendo entre 1999 e 2004.

As estações E1, E2, E4, E7, com características lóticas, formam a zona fluvial. Nas estações E5, com regime predominantemente lêntico (corpo central do reservatório, próximo à barragem), e E11, E12, E14 e E20 (também de regime lêntico, localizadas nos braços da margem esquerda do reservatório) formam a zona lacustre e as estações E8 e E12 a região de transição.

Segundo o IAP (2003), as amostras foram coletadas na superfície da água, sendo que as variáveis físicas, químicas e biológicas de qualidade de água foram monitoradas em todas as campanhas realizadas. Foram medidas em campo as seguintes variáveis: temperatura, concentração do oxigênio dissolvido e porcentagem de saturação, $\mathrm{pH}$, condutividade elétrica e transparência da água. As demais variáveis físicas e químicas, como alcalinidade, nitrato, nitrito, nitrogênio amoniacal, nitrogênio kjeldahl, sólidos totais, sólidos suspensos, DQO, DBO e fósforo total, foram analisadas em laboratório, segundo APHA (1985), sendo que as amostras foram coletadas com auxílio de garrafa de Van Dorn (capacidade para 5,5 Litros). As variáveis limnológicas e suas metodologias de análises estão apresentadas na Tabela 3.

As amostras de água para a análise do fitoplâncton (a partir de alíquota de 100 ml) e determinação de clorofila foram coletadas com garrafa de Van Dorn. O fitoplâncton foi analisado segundo o método de sedimentação de UTERMÖHL (1958), sendo que todos os organismos foram identificados até gênero e, quando possível, até espécie.

As amostras para análise do zooplâncton foram coletadas em todas as estações de amostragem com o auxílio de moto-bomba e concentradas em rede de plâncton com 
malha de $65 \mu \mathrm{m}$. A análise quantitativa foi realizada em câmara de Sedgwick - Rafter para contagem de Rotíferos e de Bogorov para contagem de cladóceros e copépodos. Todos os organismos foram identificados até gênero e, quando possível, até espécie.

Os dados de climatologia foram obitidos das estações climatológicas nas cidades de Guairá (zona fluvial), Entre Rios do Oeste (zona de transição) e Foz de Iguaçu (zona lacustre-jusante).

Tabela 3: Variáveis limnológicas e metodologias de análises.

\begin{tabular}{|c|c|c|}
\hline Variáveis & Unidade & Método \\
\hline Temperatura & ${ }^{\circ} \mathrm{C}$ & WTW mod. OXI 196 \\
\hline Oxigênio dissolvido & $\mathrm{mg} / \mathrm{L}$ & WTW mod. OXI196 \\
\hline \% Saturação de OD & $\%$ & WTW mod. OXI196 \\
\hline $\mathrm{pH}$ & unidades & potenciômetro, marca WTW mod. 196 \\
\hline Condutividade & $\mu \mathrm{S} / \mathrm{cm}$ & WTW mod. LF 191 \\
\hline Transparência & $\mathrm{m}$ & Disco de Secchi \\
\hline Alcalinidade total & $\mathrm{mg} / \mathrm{L}$ & método titulométrico usando indicador (APHA, 1992). \\
\hline Nitrato & $\mathrm{mg} / \mathrm{L}$ & APHA (1992). \\
\hline Nitrito & $\mathrm{mg} / \mathrm{L}$ & APHA (1992) \\
\hline Nitrogênio amoniacal & $\mathrm{mg} / \mathrm{L}$ & $\begin{array}{l}\text { espectrofotômetro e o limite de detecção é }<0,02 \mathrm{mg} \text {.L-1 de } \\
\mathrm{N} \text { (APHA, 1992). }\end{array}$ \\
\hline $\begin{array}{l}\text { Nitrogênio } \quad \text { total } \\
\text { Kjeldahl }\end{array}$ & $\mathrm{mg} / \mathrm{L}$ & método do fenato (APHA, 1992). \\
\hline Turbidez & NTU & Turbidímetro marca HACH, modelo 2100 A (APHA,1985). \\
\hline DQO & $\mathrm{mg} / \mathrm{L}$ & APHA (1992) \\
\hline $\mathrm{DBO}_{5}$ & $\mathrm{mg} / \mathrm{L}$ & APHA (1992)). \\
\hline Fósforo total & $\mathrm{mg} / \mathrm{L}$ & $\begin{array}{l}\text { O fósforo foi determinado através do método do ácido } \\
\text { ascórbico (APHA (1992)). }\end{array}$ \\
\hline $\begin{array}{l}\text { Resíduos totais a } \\
103^{\circ} \mathrm{C}\end{array}$ & $\mathrm{mg} / \mathrm{L}$ & APHA (1992) \\
\hline Clorofila- $a$ & $\mathrm{mg} / \mathrm{m}^{3}$ & $\begin{array}{l}\text { Espectrofotômetro, marca DMS 100, nos comprimentos de } \\
\text { onda 750nm e 665nm, segundo método de NUSCH (1980) }\end{array}$ \\
\hline
\end{tabular}

\subsection{Análise dos dados}

\subsubsection{Fitoplâncton}

Os resultados da análise de fitoplâncton são apresentados numericamente (organismos/ml) e em termos de abundância relativa, separando-se em quatro classes: Cyanophyceae, Chlorophyceae, Bacillariophyceae e Fitoflagelados. 


\subsubsection{Zooplâncton}

Os resultados das análises de zooplâncton são apresentados numericamente (organismos/ml) e em termos de abundância relativa, separando-se em Rotífera, Cladocera e Copepoda.

\subsubsection{Peixes}

Os dados sobre os peixes foram agrupados em guildas tróficas, de acordo com OLIVEIRA et al. (2005). Assim, foram calculadas as abundâncias relativas de cada guilda trófica e as densidades numéricas foram expressas em quilogramas, correspondendo ao peso do peixe eviscerado sem cabeça. Isto ocorreu porque os dados de levantamento do estoque pesqueiro do reservatório são provenientes do desembarque de peixes de pescadores profissionais, sendo todo o pescado desembarcado encontrado nesta situação.

\subsubsection{Análise dos níveis tróficos}

As abundâncias numéricas e relativas do fitoplâncton, zooplâncton e peixes foram apresentados de acordo com as regiões (fluvial, transição e lacustre) do reservatório para comparação dos padrões de distribuição espacial. Estas análises foram realizadas com o intuito de revelar as relações existentes entre os níveis tróficos do reservatório.

\subsection{Análise estatística dos dados}

Os valores das variáveis físicas e químicas e das comunidades de fitoplâncton e zooplâncton das zonas fluvial, transição e lacustre correspondem aos valores médios (da superfície) das estações de coleta dentro de cada região. Este agrupamento foi 
necessário para efeito de comparação, porque os dados de peixes foram disponibilizados desta maneira.

Para testar a hipótese de cascata trófica no reservatório foram realizadas análises de regressão linear entre as variáveis físicas, químicas, biológicas e as guildas tróficas, com os níveis tróficos analisados um a um, determinando assim as interações entre os mesmos. Esta seqüência de análise foi seguida de acordo com modelos de cadeias alimentares (Top down e Bottom up) (CARPENTER et al., 1985, MCQUEEN et al., 1986, LAZZARO, 1997; LAZZARO et al. 2003). Os gráficos obtidos foram avaliados para decidir se as relações eram lineares ou não. Para estabilizar a variância, foram tomados os logaritmos neperianos de todas as variáveis limnológicas. Graficamente, as variáveis limnológicas foram expressas de acordo com a equação abaixo:

$$
\log _{10} \text { variável }=\log _{10}(\text { var variável })
$$

onde var é o valor original da variável limnológica, In var o valor transformado de var.

Para as variáveis bióticas, no intuito de minimizar os valores nulos, a transformação foi realizada de acordo com a equação abaixo:

$$
\log _{10} \text { bio }=\log _{10}(\text { bio }+1)
$$

onde bio é o valor original da variável biótica +1 , ln bio é o valor transformado de bio.

Foi feita análise dos resíduos para examinar os pressupostos de linearidade, normalidade e homocedasticidade a fim de validar os modelos.

Para a realização das análises e dos gráficos foram utilizados as versões demos dos programas estatísticos SYSTAT 10, SIGMAPLOT 2001 e SIGMASTAT 3.1, todos versões demonstrativas.

\subsubsection{Análise das variáveis limnológicas}

Preliminarmente, os dados de todas as variáveis limnológicas foram examinados através da análise de SPLOM (ScatterPLOt Matrix), para verificar o tipo de dispersão entre as variáveis. Como não houve ajuste linear ente os pontos, os dados foram então transformados para log-log na base 10 e $\log -\log$ na base $e$ no intuito de linearizar estas 
relações. O melhor ajuste foi observado na análise de SPLOM com os dados transformados para log-log na base $e$.

\subsubsection{Análise das variáveis biológicas (guildas de peixes, fitoplâncton e zooplâncton) e nutrientes (fósforo total e TKN)}

Preliminarmente foram realizadas análises de SPLOM para verificação de um padrão de distribuição dos pontos. Os dados foram então transformados para log-log na base 10 e $\log -\log$ na base $e$ no intuito de linearizar as relações entre as variáveis. $\mathrm{O}$ melhor ajuste foi observado na análise de SPLOM com os dados transformados para $\log -\log$ na base $e$.

Foram realizadas análises de correlação entre as variáveis biológicas mais fósforo total e TKN. Esta análise foi escolhida por estudar o grau de associação entre as variáveis e determinar se esta relação é ou não significativa (TABACHINICK \& FIDELL, 2001).

\subsubsection{Análises de Covariância (ANCOVA)}

Após as análises preliminares, se decidiu aplicar modelos de ANCOVA, aos dados logaritmizados na base $e$, com o fator zona do reservatório com três níveis $(1=$ Fluvial, 2= Transição e 3= Lacustre), considerando-se separadamente, para as variáveis limnológicas:

1. Profundidade de disco de secchi (variável dependente) e demais variáveis limnológicas (variáveis independentes);

2. Concentração de clorofila (variável dependente) e demais variáveis limnológicas (variáveis independentes);

3. Concentração de cianobactérias (variável dependente) e demais variáveis limnológicas (variáveis independentes).

Para as variáveis biológicas também foram aplicados modelos de ANCOVA aos dados logaritmizados na base $e$, com o fator zona do reservatório com três níveis $(1=$ Fluvial, 2= Transição e 3= Lacustre), considerando-se separadamente: 
1. Concentração de clorofila (variável dependente) e guildas tróficas de peixes e as formas de nutrientes fósforo total e concentração de TKN (variáveis independentes);

2. Concentração de cianobactérias (variável dependente) e guildas tróficas de peixes as formas de nutrientes fósforo total e concentração de TKN (variáveis independentes).

As variáveis independentes foram tomadas como variáveis resposta (Y) (HUITEMA, 1980) e os dados foram agrupados de acordo com a zona do reservatório (fluvial, transição e lacustre) no intuito de se obter um desenho experimental mais balanceado (KOTAS, 2004). As análises têm caráter exploratório, ao tentar se entender a estrutura de correlação entre as variáveis do modelo, em busca de um modelo mínimo que melhor a explique. Assim as interações e as variáveis não significativos em nível de $5 \%$ foram sucessivamente descartados.

$\mathrm{Na}$ análise de resíduos, além dos histogramas e do diagrama de dispersão entre os resíduos e os valores estimados pelo modelo, foi realizado o teste de Lilliefors nesses resíduos para testar sua normalidade (LEGENDRE \& LEGENDRE, 1998).

Para a comparação entre as médias das ANCOVAs, duas etapas foram seguidas: (a) a execução da análise de covariância e a verificação da significância do teste $F$ olhando-se o p-value do output do programa utilizado, daí adotando-se como usual significância a 5\%, e (b) teste tipo LSD de Fisher a posteriori para a comparação de pares médias ajustadas por covariância ao nível de significância de 5\% (HUITEMA, 1980). Assim, para cada par de médias obtidas, foi calculado o erro padrão:

$$
S \bar{Y}_{i a d j}-\bar{Y}_{j a d j}=\sqrt{\operatorname{MSreS}_{w}\left[\left[\frac{1}{n_{i}}+\frac{1}{n_{j}}\right]+\frac{\left(\bar{X}_{i}-\bar{X}_{j}\right)^{2}}{S S_{w_{x}}}\right]} \text { (equação 1) }
$$

Onde

$\mathrm{MSres}_{\mathrm{w}}=$ resíduo da análise de covariância, obtido da tabela da análise de covariância; $n_{i}, n_{j}=$ tamanhos das amostras para os grupos $i$ e $j$, respectivamente; $\overline{X_{i}}, \overline{X_{j}}=$ médias das covariáveis para os grupos $i$ e $j$, respectivamente; $S S_{w_{r}}=$ soma dos quadrados dentro dos grupos, obtida da tabela da ANOVA da covariável.

Foi então aplicado um teste $t$ com $N-4$ (N-(número de níveis de ZR=3) -1)) graus de liberdade, de acordo com a equação: 


$$
t=\frac{\bar{Y}_{i a d j}-\bar{Y}_{j a d j}}{S \bar{Y}_{i a d j}-\bar{Y}_{j a d j}} \quad \text { (equação 2) }
$$

\section{6. Índice de estado trófico (IET)}

Para a avaliação do estado trófico do reservatório de Itaipu, foi utilizado o índice de estado trófico, proposto por CARLSON e modificado por TOLEDO JR. et al. (1983), conforme descrito abaixo:

$$
\begin{gathered}
\text { IET }(\text { Secchi })=10\left[6-\left(\frac{0,64+\ln \text { Secchi }}{\ln 2}\right)\right] \\
\text { IET }(\text { P.Total })=10\left[6-\left(\frac{\ln \{80,32 / \text { P.total }\}}{\ln 2}\right)\right] \\
\text { IET }(\text { Clorofila })=10\left[6-\left(\frac{2,04-0,695 * \ln \text { Clorofila }}{\ln 2}\right)\right]
\end{gathered}
$$

Para a determinação de um IET (médio), o cálculo deste índice foi feito utilizando-se a média ponderada, atribuindo-se menor peso à transparência da água, como sugerido por TOLEDO JR. et al. (1983). Assim, para o cálculo do IET (médio), utilizou-se a seguinte fórmula:

$$
\operatorname{IET}(\text { Médio })=\frac{\operatorname{IET}(\text { Secchi })+2[\operatorname{IET}(\text { P.total })+\operatorname{IET}(\text { Clorofila })]}{5}
$$

A partir do IET médio os critérios para a classificação do estado trófico são:

\begin{tabular}{lc}
\hline Oligotrófico & IET $\leq 44$ \\
Mesotrófico & $44<$ IET $<54$ \\
Eutrófico & IET $\geq 54$ \\
\hline
\end{tabular}

\subsection{Estimativa da produtividade pesqueira}

Através do Índice Morfoedáfico (MEI) de RYDER (1965), a produtividade pesqueira foi estimada e o MEI foi expresso pela seguinte equação: 


$$
M E I=\frac{T D S}{z m} \text { ou } M E I=\frac{\text { condutividade }}{z m}
$$

Onde:

TDS= concentração de sólidos dissolvidos (mg/L);

$\mathrm{zm}=$ profundidade média $(\mathrm{m})$.

Foram realizadas análises de correlação entre este índice e as variáveis transparência da água e clorofila, no intuito de verificar quais as variáveis apresentariam efeito positivo ou negativo sobre o MEI.

\subsubsection{Inferência da produtividade pesqueira}

Com o intuito estimar a produtividade pesqueira no reservatório de Itaipu e verificar se índices preditivos correspondem aos dados do desembarque pesqueiro, foi utilizada a equação proposta por MELACK (1976), com o modelo gerado a partir de uma análise de regressão de dados de captura e MEI (índice morfoedáfico):

$$
F Y=4,1 \times M E I^{0,8}
$$

O índice abaixo (MEI) é uma relação entre a concentração de sólidos dissolvidos na água dividido pela profundidade média do lago ou reservatório, e foi utilizado pela primeira vez por RYDER (1965) na estimativa da produtividade de lagos africanos. OGLESBY (1977) verificou que um melhor ajuste podia ser obtido para o MEI expresso pela relação da condutividade pela profundidade média.

Onde:

$$
M E I=\frac{\text { condutividade }\left(\mu \mathrm{S} \cdot \mathrm{cm}^{-1}\right)}{\text { profundidade média }(m)}
$$




\section{RESULTADOS}

\subsection{Precipitação}

Pelos valores de precipitação verifica-se uma variação sazonal, sendo que em novembro, em todos os anos de estudo, ocorreram as maiores precipitações. $\mathrm{O}$ valor médio da precipitação foi de $141 \mathrm{~mm}$, com a zona de transição apresentando maior precipitação média $(150 \mathrm{~mm})$. O maior pico de chuva ocorreu em novembro de 2002, com 492,6 mm, e o menor foi de 0,4 mm, em agosto de 1999 (Figura 6).

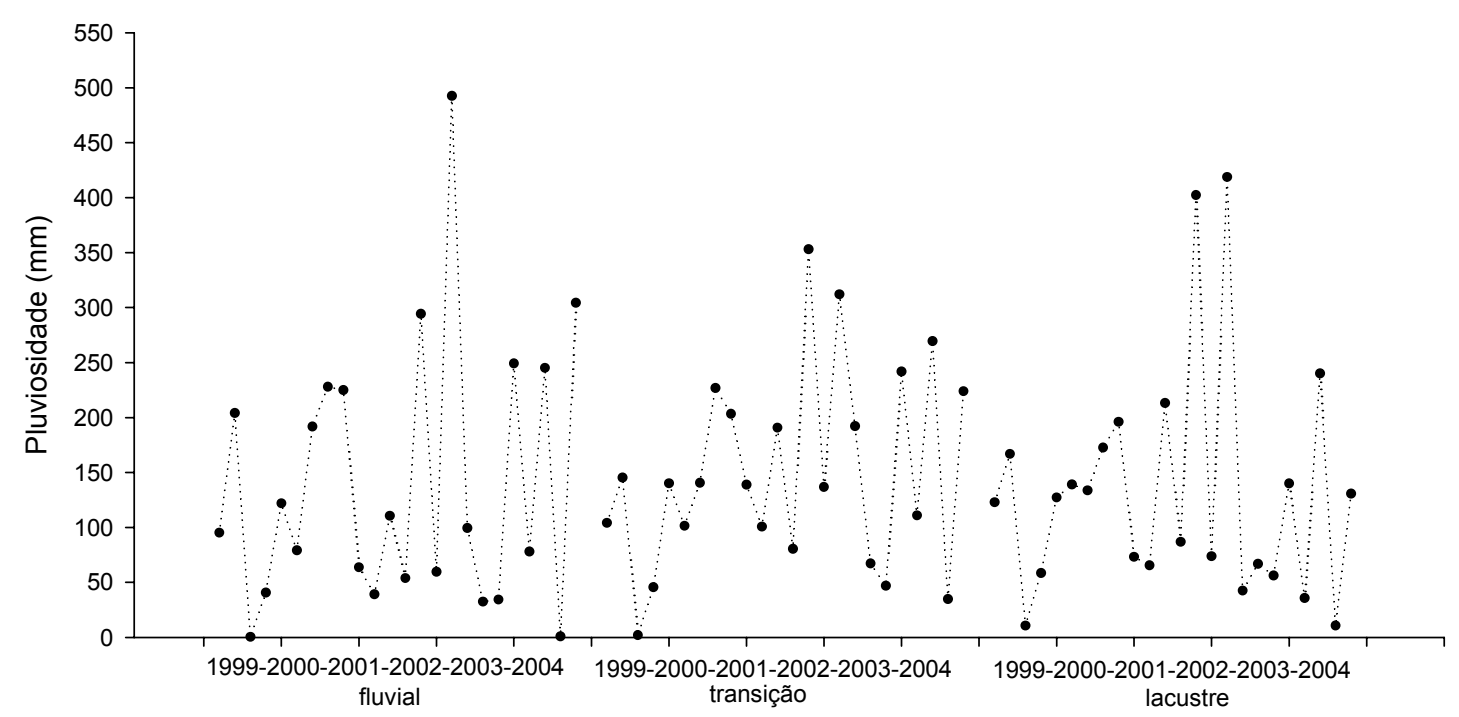

Figura 6: Variação da pluviosidade (média trimestral) de acordo com as zonas do reservatório de Itaipu, para o período de 1999 a 2004. 


\subsection{Variáveis Limnológicas}

\subsubsection{Temperatura da água}

A distribuição da temperatura da água, de acordo com as zonas do lago, ao longo do tempo, pode ser observada na Figura 7. A sazonalidade na distribuição da temperatura se mostra de maneira bem clara, com as temperaturas mais elevadas registradas nos meses de novembro a março e as temperaturas mais amenas nos meses de Maio a Agosto. A temperatura média foi de $24,3^{\circ} \mathrm{C}$, sendo a mais baixa de $16,4^{\circ} \mathrm{C}$ e a mais alta de $30,4^{\circ} \mathrm{C}$.

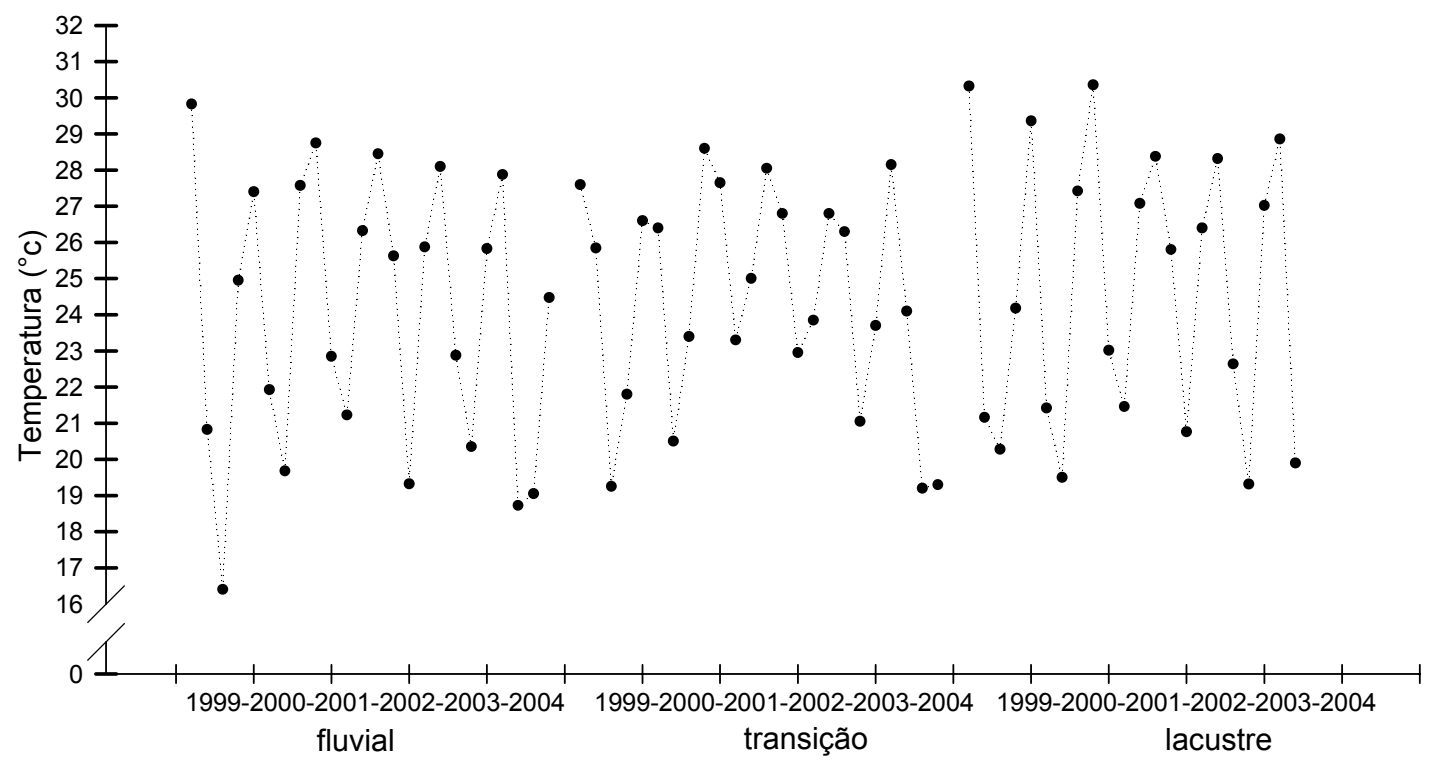

Figura 7: Variação dos valores de temperatura (média trimestral) e distribuição de acordo com as zonas do reservatório de Itaipu, para o período de 1999 a 2004.

\subsubsection{Transparência da água}

Na Figura 8 apresenta-se a variação da transparência da água no reservatório, verificando-se um aumento dos valores no sentido da zona fluvial para a zona lacustre. A transparência média foi de $1,2 \mathrm{~m}$, a máxima foi de $2,3 \mathrm{~m}$ (na zona lacustre) e a mínima foi de $0,4 \mathrm{~m}$ (na zona fluvial). 


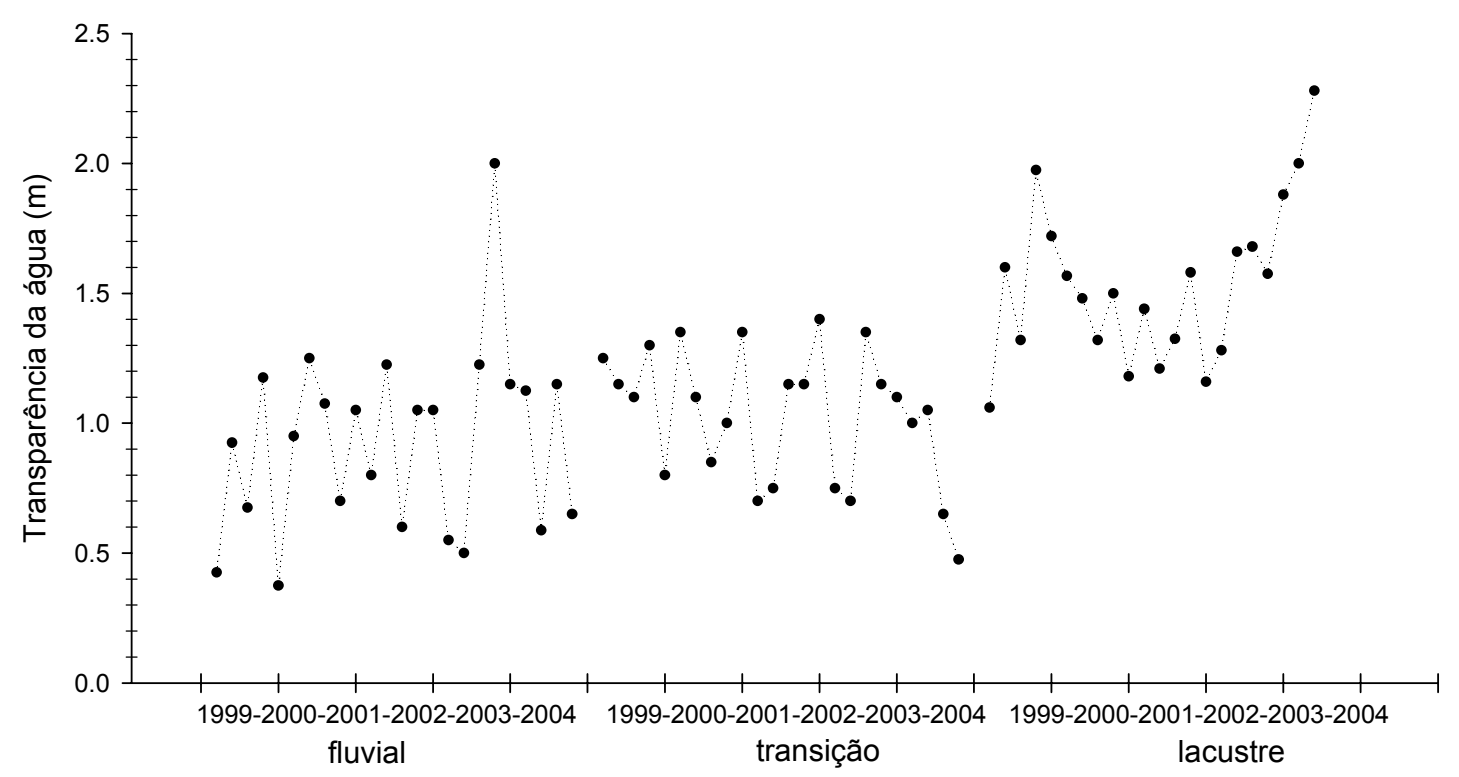

Figura 8: Variação dos valores de transparência da água (média trimestral) de acordo com as zonas do reservatório de Itaipu, para o período de 1999 a 2004.

\subsubsection{Sólidos suspensos totais}

Na Figura 9 observa-se a distribuição dos valores de sólidos suspensos totais no reservatório de Itaipu. O valor médio para o reservatório foi de $6,9 \mathrm{mg} / \mathrm{L}$; o valor máximo observado foi de $21,5 \mathrm{mg} / \mathrm{L}$ na zona fluvial (valor médio $10,9 \mathrm{mg} / \mathrm{L}$ ) e a menor concentração foi de $2 \mathrm{mg} / \mathrm{L}$ na zona lacustre (concentração média de 3,4 mg/L).

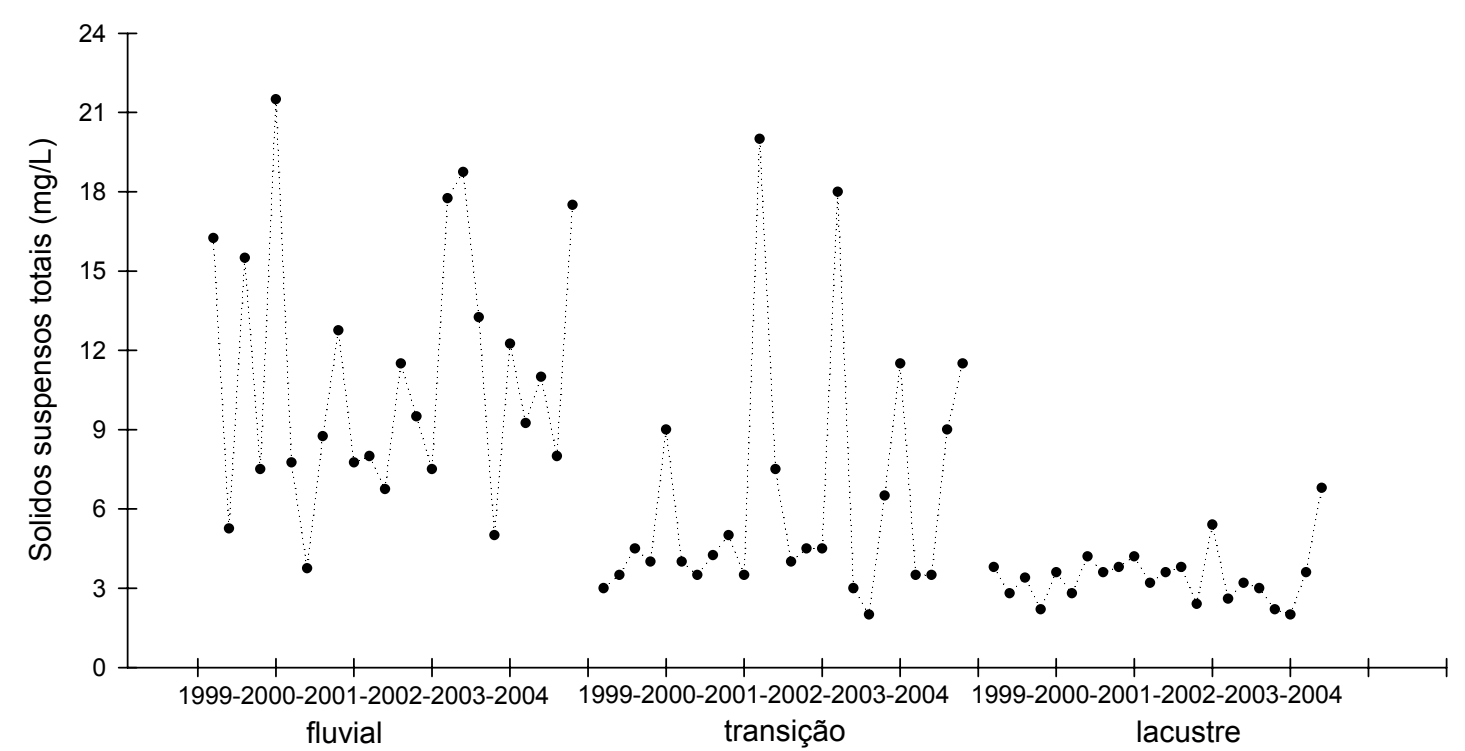

Figura 9: Variação dos valores de sólidos suspensos totais (média trimestral) de acordo com as zonas do reservatório de Itaipu, para o período de 1999 a 2004. 


\subsubsection{Turbidez}

A distribuição da turbidez no reservatório foi homogênea, exceto nas regiões de transição e fluvial. Foram registrados picos de 185 e 95,8 NTU no ano de 2004 (na zona de transição e fluvial, respectivamente) e o menor valor foi de 3,3 NTU na zona lacustre. As concentrações médias de turbidez, de acordo com as respectivas zonas, foram de 20,3; 23 e 9,2 NTU (Figura 10).

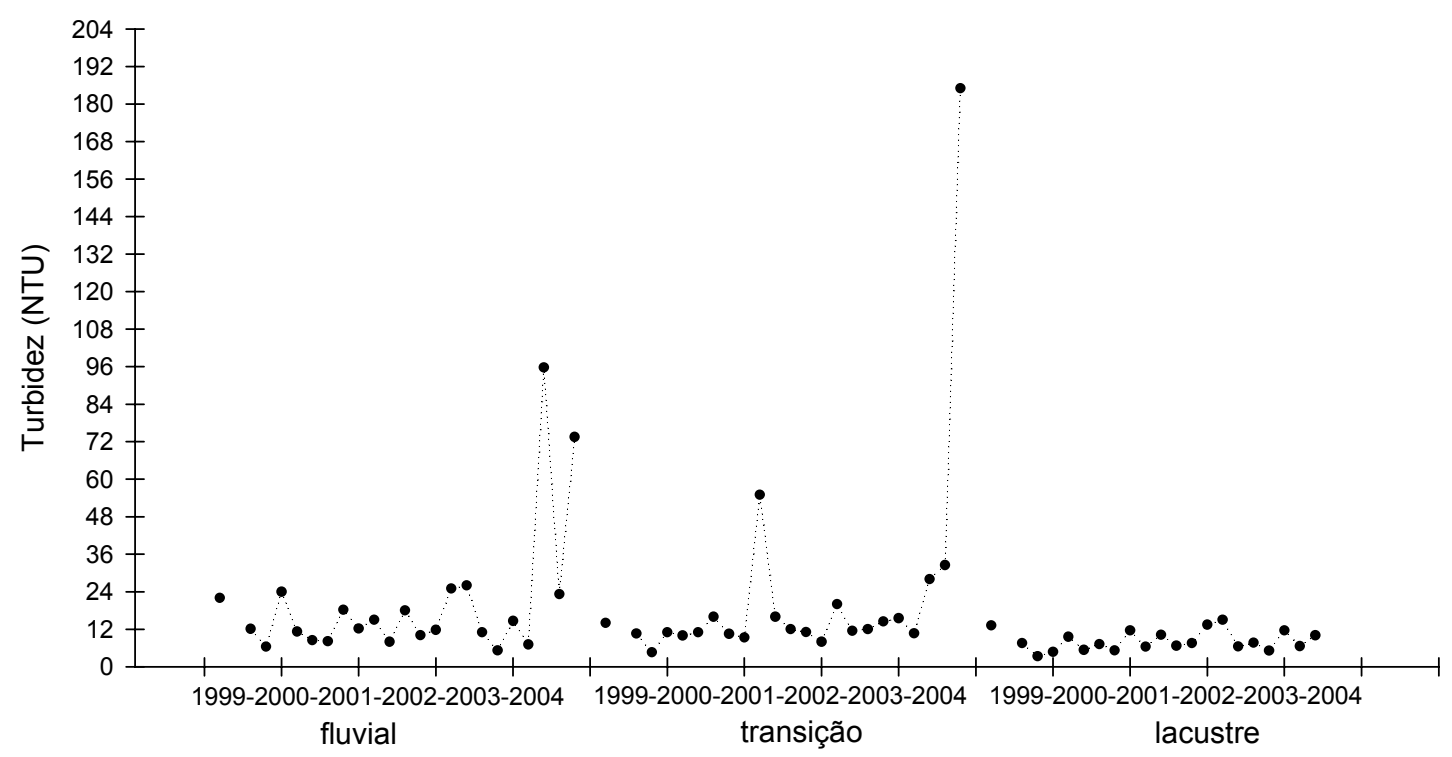

Figura 10: Variação dos valores de turbidez (média trimestral) de acordo com as zonas do reservatório de Itaipu, para o período de 1999 a 2004.

\subsubsection{Alcalinidade}

Na Figura 11 observa-se a distribuição da alcalinidade no reservatório, com média de $21,7 \mathrm{mg} / \mathrm{L}$ e mínima de $15,5 \mathrm{mg} / \mathrm{L}$ para todo o reservatório. Para a zona fluvial foram observados dois picos de 29,8mg/L e 29,3mg/L no final de 2003 e final de 2004 , respectivamente. $\mathrm{Na}$ zona de transição ocorreu um descrécimo para 15,5 mg/L, em maio de 2001, e um valor mais elevado (30,5 mg/L) no início de 2004. 


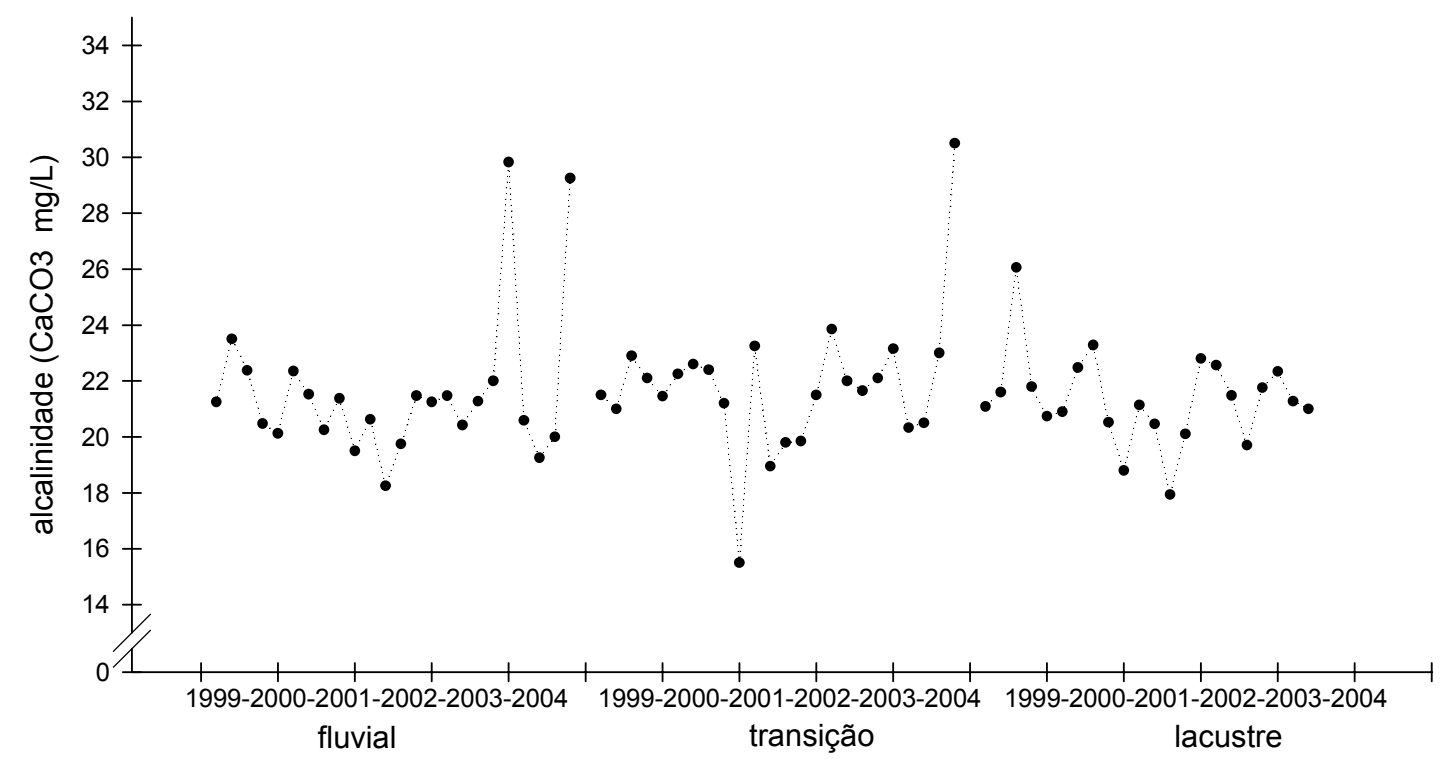

Figura 11: Variação dos valores de alcalinidade (média trimestral) de acordo com as zonas do reservatório de Itaipu, para o período de 1999 a 2004.

\subsection{6. pH}

Observando a Figura 12, verifica-se que o reservatório apresentou uma tendência ao pH mais alcalino, com valores médios de 7,6, máximo de 8,9 e mínimo de 6,6. Três aumentos de $\mathrm{pH}$ foram observados em março de 2003 e novembro de 2004 na zona fluvial, e outro em maio de 2003 na zona de transição. Os valores médios foram de 7,5 (zona fluvial), 7,8 (zona de transição) e 7,6(zona lacustre).

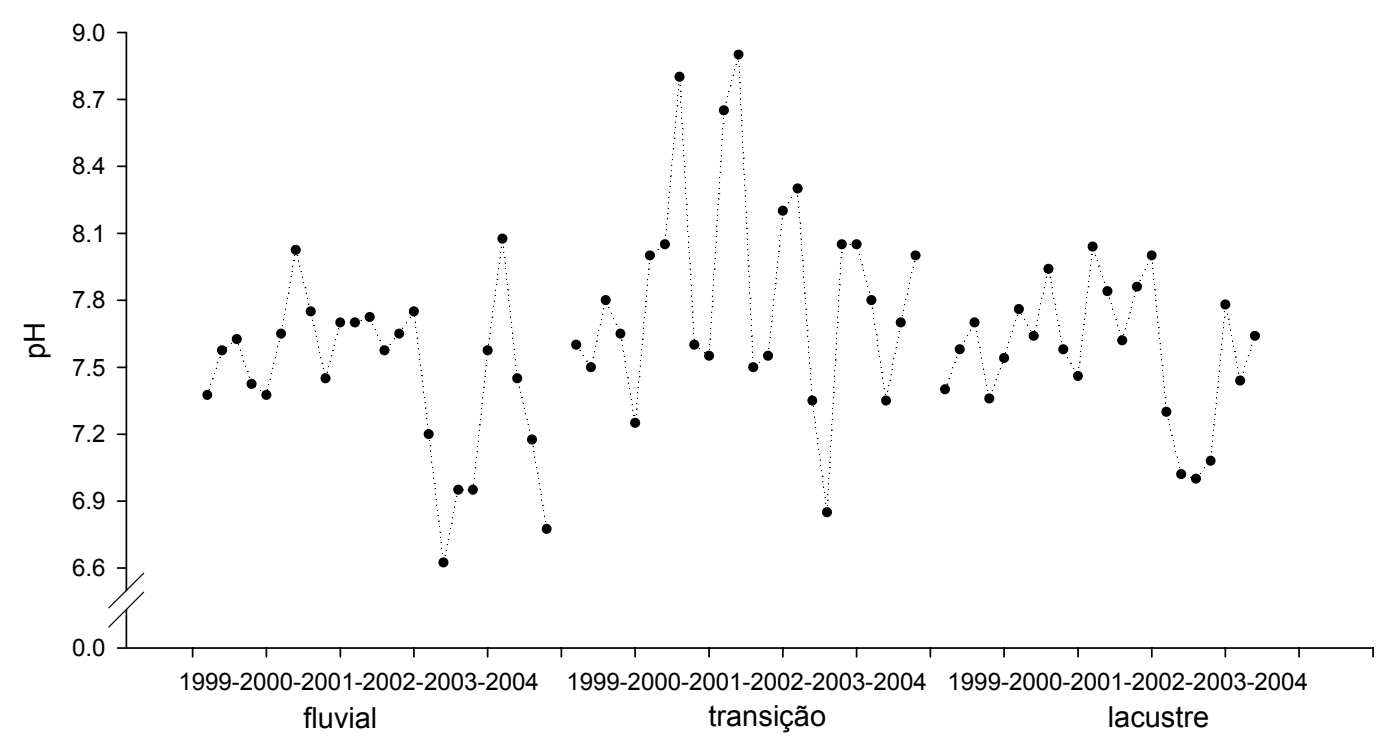

Figura 12: Variação dos valores de $\mathrm{pH}$ (média trimestral) de acordo com as zonas do reservatório de Itaipu, para o período de 1999 a 2004. 


\subsubsection{Condutividade}

Na Figura 13 observam-se os valores de condutividade obtidos no reservatório de Itaipú. O valor médio foi de $51,9 \mu \mathrm{S} . \mathrm{cm}^{-1}$, sendo que o valor máximo de $61 \mu \mathrm{S} . \mathrm{cm}^{-1}$ ocorreu na zona de transição e o mínimo de $43,4 \mu{\mathrm{S} . \mathrm{cm}^{-1}}^{-1}$ na zona lacustre.

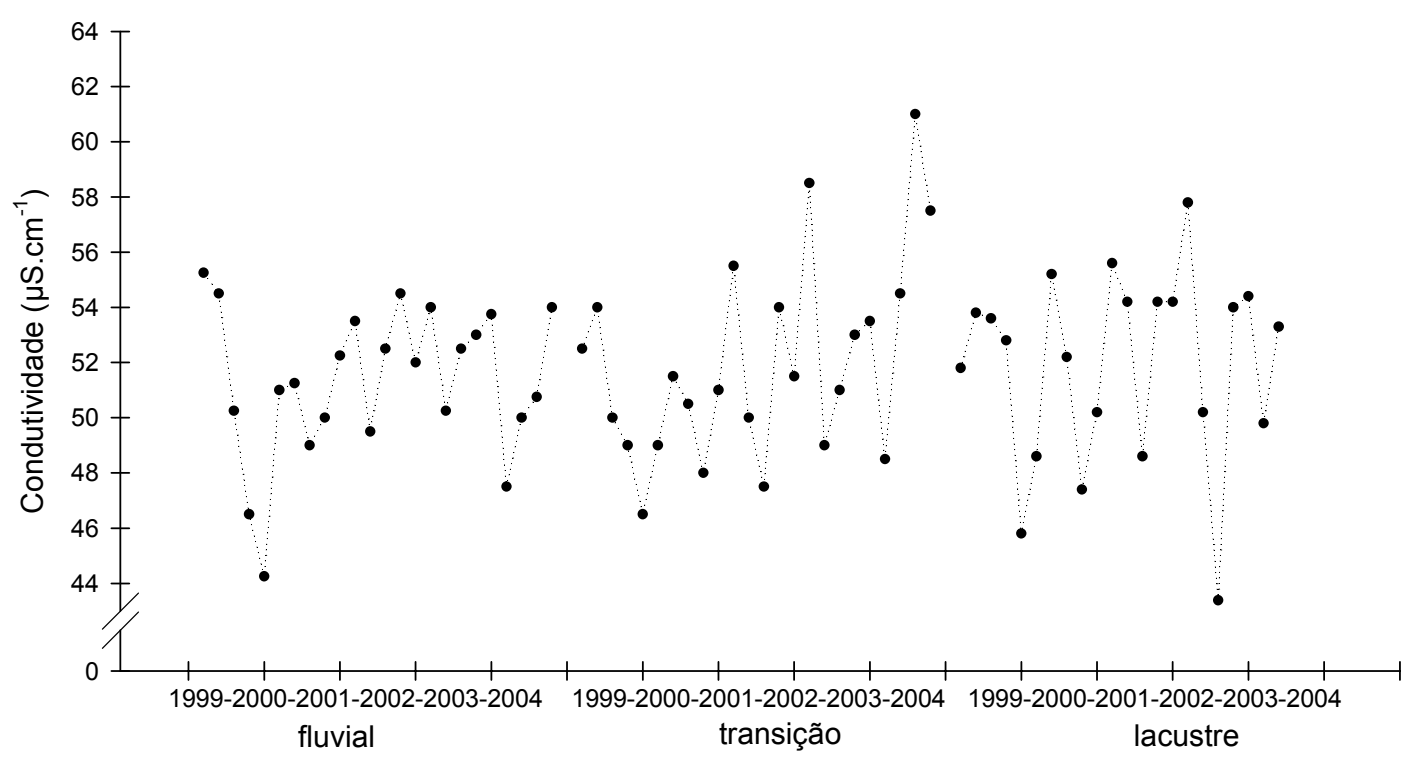

Figura 13: Variação dos valores de condutividade (média trimestral) de acordo com as zonas do reservatório de Itaipu, para o período de 1999 a 2004.

\subsubsection{Oxigênio dissolvido (OD)}

Na Figura 14 apresentam-se a distribuição de OD nas diferentes zonas do reservatório, verificando-se valor médio de $8,2 \mathrm{mg} / \mathrm{L}$, máximo de $12,1 \mathrm{mg} / \mathrm{L}$ na zona de transição e mínimo de $6,7 \mathrm{mg} / \mathrm{L}$. Os valores médios das concentrações de oxigênio dissolvido para as respectivas zonas foram de $8,1 \mathrm{mg} / \mathrm{L}, 8,5 \mathrm{mg} / \mathrm{L} \mathrm{e} 8,1 \mathrm{mg} / \mathrm{L}$. 


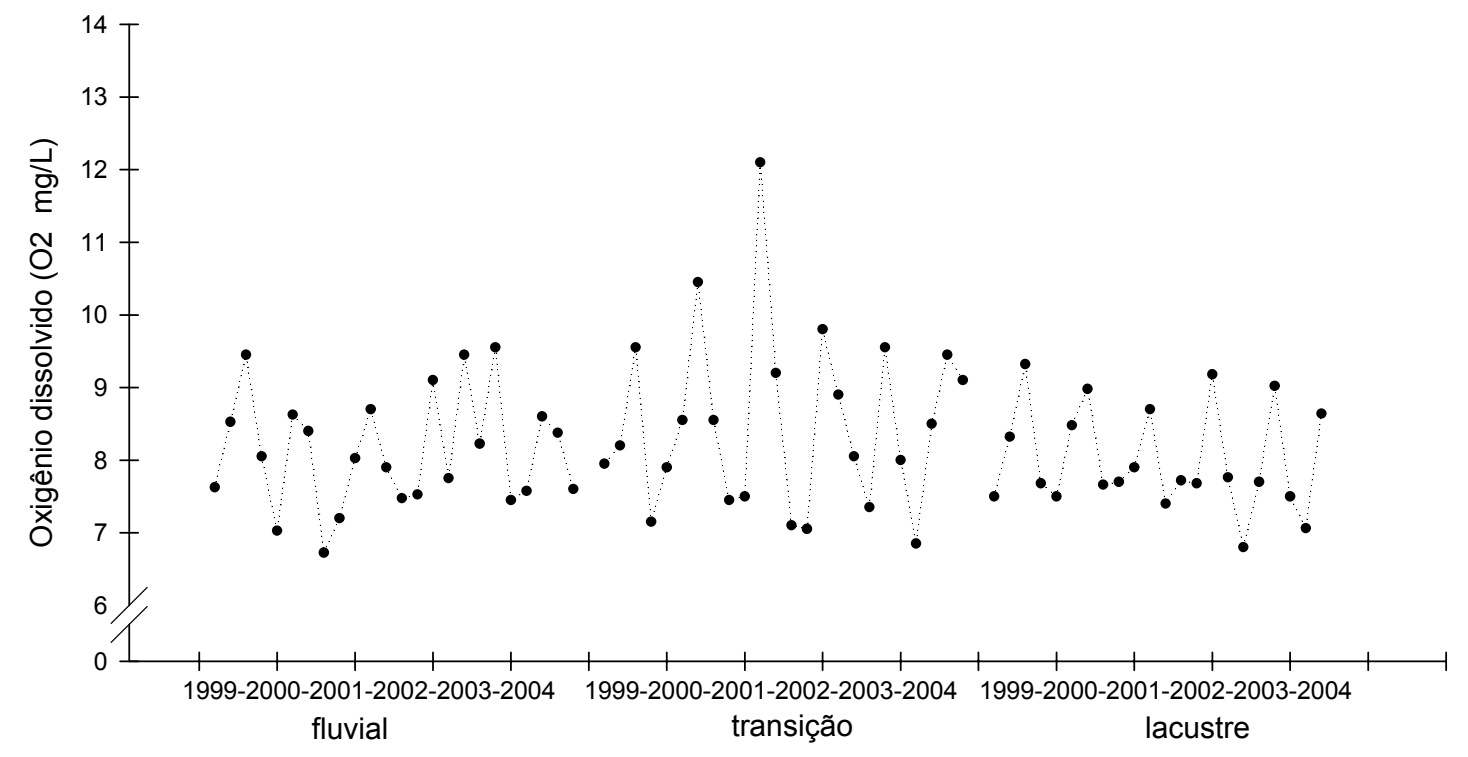

Figura 14: Variação da concentração de oxigênio dissolvido (média trimestral) de acordo com as zonas do reservatório de Itaipu, para o período de 1999 a 2004.

\subsection{9. $\mathrm{DBO}_{5}$}

A Figura 15 representa a variação da $\mathrm{DBO}_{5}$ no eixo longitudinal do reservatório de Itaipu. $\mathrm{O}$ valor médio foi de $2,2 \mathrm{mg} / \mathrm{L}$, e os maiores valores de $\mathrm{DBO}_{5}$ foram obtidos na zona de transição $(2,7 \mathrm{mg} / \mathrm{L})$. A zona fluvial e a lacustre apresentaram valores médios de 1,8 e 2,0mg/L, respectivamente. Os maiores valores ocorreram na zona de transição nos meses de agosto de 2001 e novembro de 2004.

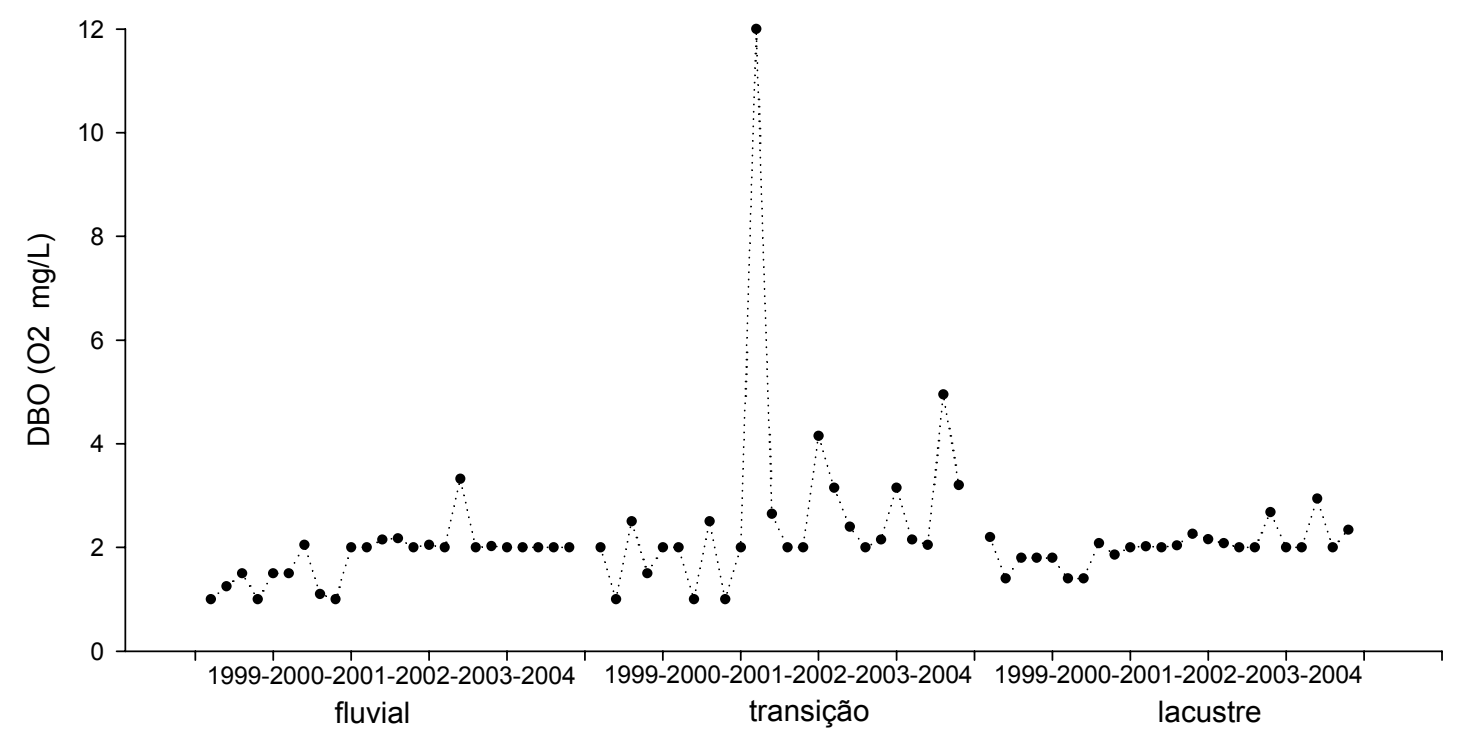

Figura 15: Variação dos valores de $\mathrm{DBO}_{5}$ (média trimestral) de acordo com as zonas do reservatório de Itaipu, para o período de 1999 a 2004. 


\subsubsection{DQO}

A Figura 16 representa a variação da DQO ao longo do reservatório, registrando-se uma concentração média de $6,5 \mathrm{mg} / \mathrm{L}$. A zona que apresentou a maior concentração média foi a de transição $(7,5 \mathrm{mg} / \mathrm{L})$, e as zonas fluvial e lacustre obtiveram concentrações médias de 5,5 e $6,5 \mathrm{mg} / \mathrm{L}$, respectivamente. $\mathrm{O}$ maior pico foi observado em agosto de 2001 e novembro de 2004, na zona de transição.

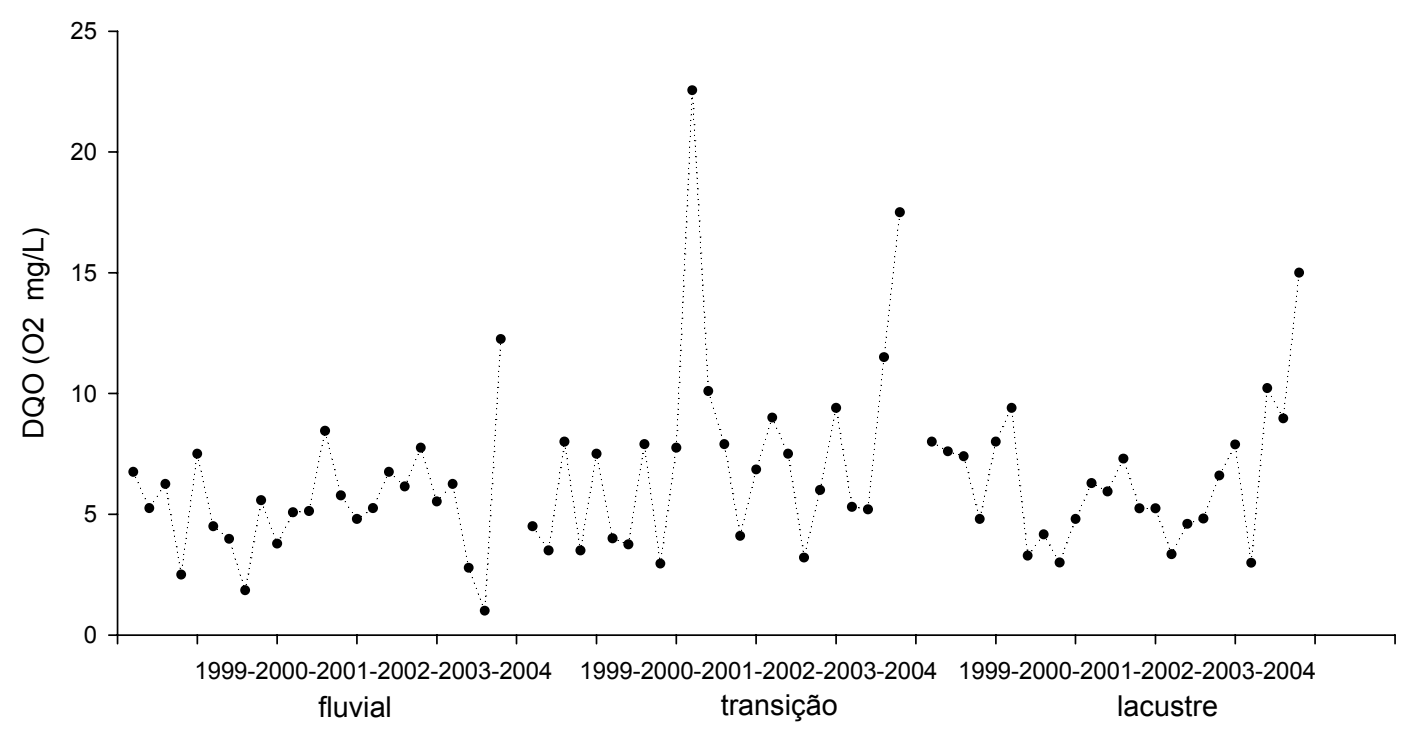

Figura 16: Variação dos valores de DQO (média trimestral) de acordo com as zonas do reservatório de Itaipu, para o período de 1999 a 2004.

\subsubsection{Nitrato}

A Figura 17 mostra dois picos bem evidentes, um na zona de transição, em agosto de $2004(0,84 \mathrm{mg} / \mathrm{L})$ e outro na zona lacustre no mês de agosto de 2000 $(0,92 \mathrm{mg} / \mathrm{L})$. A concentração média para o reservatório foi de $0,29 \mathrm{mg} / \mathrm{L}$ e a zona de transição foi aquela em que se obteve a maior concentração média de nitrato $(0,32 \mathrm{mg} / \mathrm{L})$, enquanto que a zona lacustre foi a que apresentou menor concentração $(0,06 \mathrm{mg} / \mathrm{L})$. As concentrações médias de nitrato para suas respectivas zonas foram de 0,$28 ; 0,32$ e $0,28 \mathrm{mg} / \mathrm{L}$. 


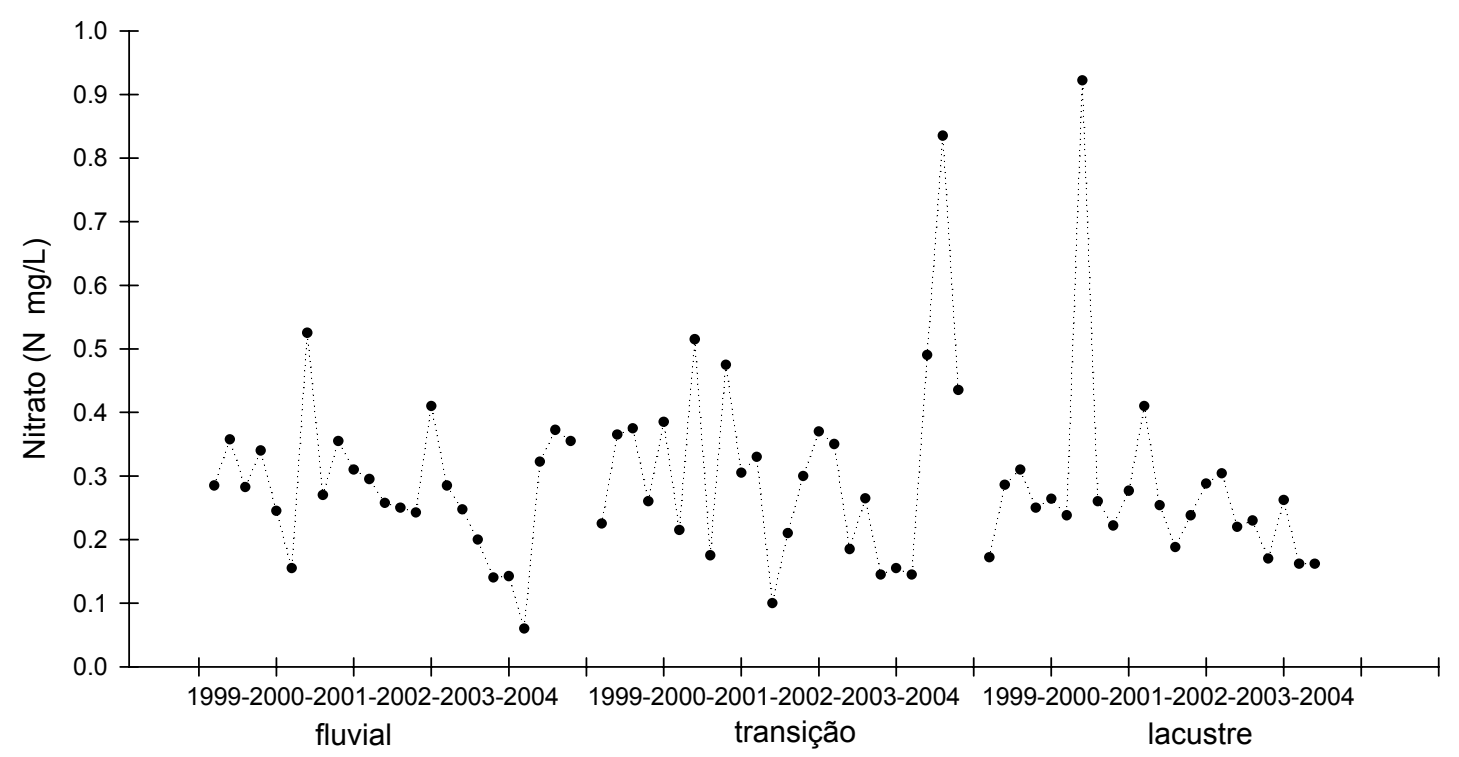

Figura 17: Variação das concentrações de nitrato (média trimestral) de acordo com as zonas do reservatório de Itaipu, para o período de 1999 a 2004.

\subsubsection{Nitrito}

A concentração média de nitrito foi de $0,006 \mathrm{mg} / \mathrm{L}$, com máximo de $0,021 \mathrm{mg} / \mathrm{L}$ na zona de transição em maio de 2004 e mínimo de $0,002 \mathrm{mg} / \mathrm{L}$ na zona fluvial. Em todas as zonas esta variável permaneceu com concentração média de $0,005 \mathrm{mg} / \mathrm{L}$, sendo que os menores valores médios ocorreram na zona de transição $(0,32 \mathrm{mg} / \mathrm{L})$, e nas demais o valor médio foi de $0,28 \mathrm{mg} / \mathrm{L}$ (Figura 18).

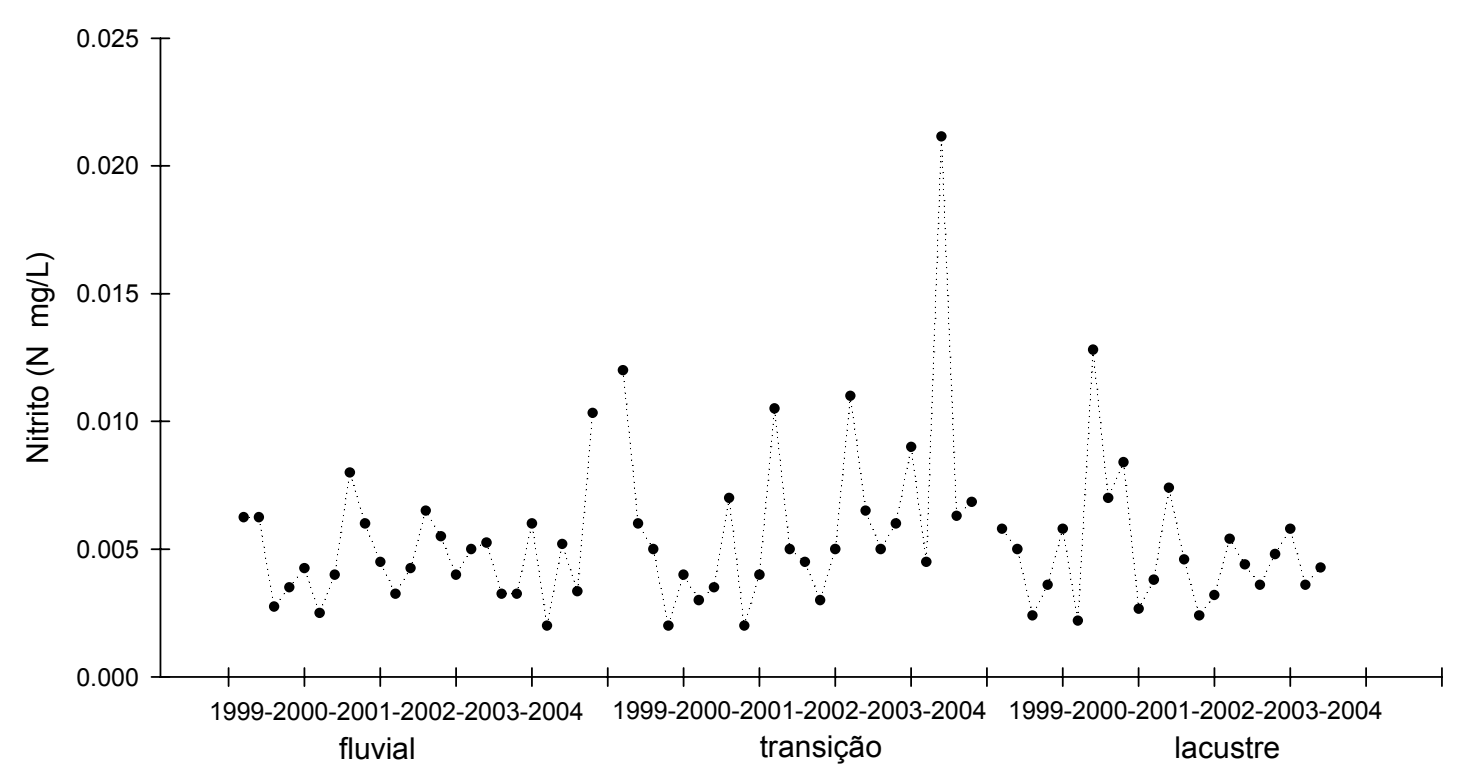

Figura 18: Variação da concentração de nitrito (média trimestral) de acordo com as zonas do reservatório de Itaipu, para o período de 1999 a 2004. 


\subsubsection{Nitrogênio total kjeldahl (TKN)}

A zona de transição foi a que apresentou as maiores concentrações de $\mathrm{TKN}$, com máximo de $0,98 \mathrm{mg} / \mathrm{L}$ em novembro de 2000 (Figura 19). O valor médio para esta variável no reservatório foi de $0,33 \mathrm{mg} / \mathrm{L}$ e o valor mínimo foi de $0,04 \mathrm{mg} / \mathrm{L}$, na zona fluvial, em maio de 1999.

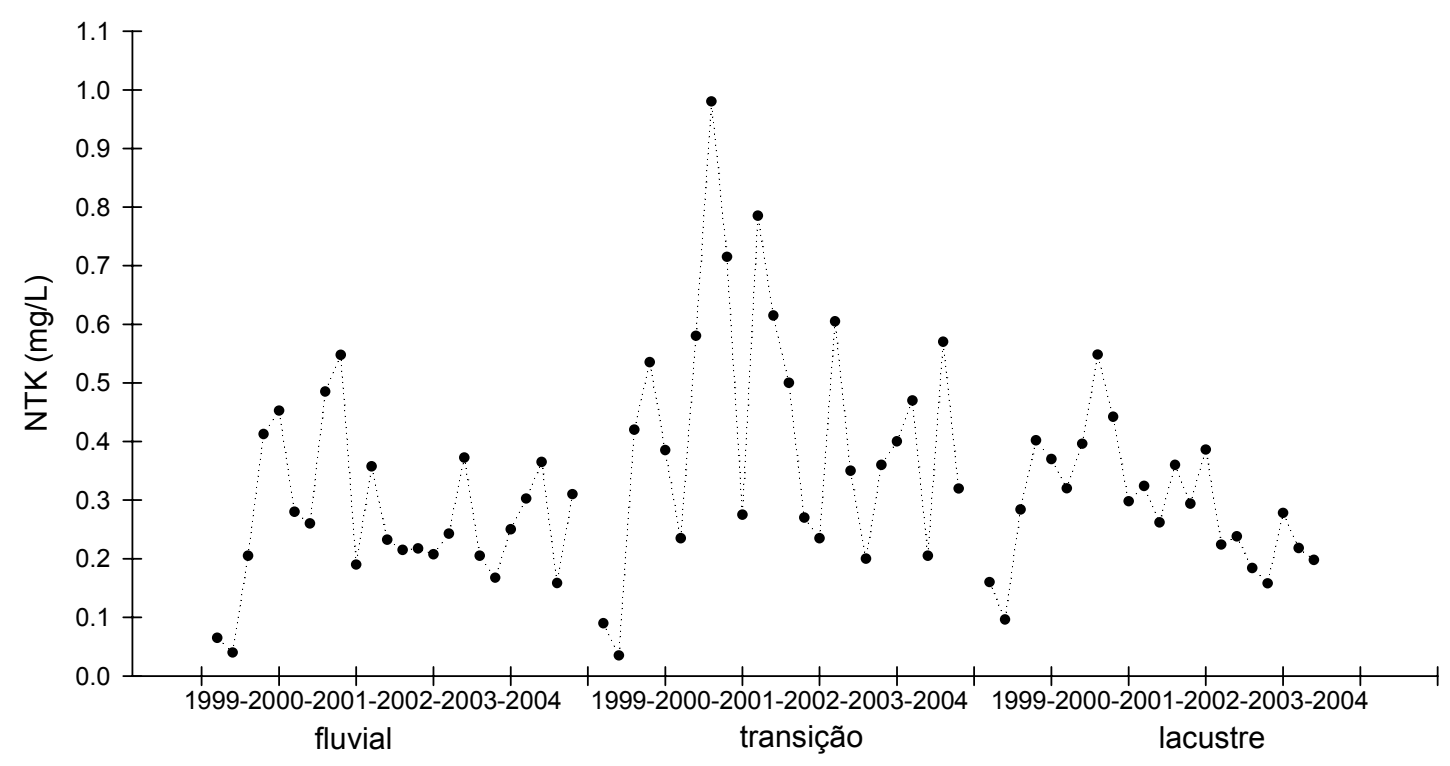

Figura 19: Variação da concentração de TKN (média trimestral) de acordo com as zonas do reservatório de Itaipu, para o período de 1999 a 2004.

\subsubsection{Nitrogênio amoniacal}

Na Figura 20 está representada a distribuição do nitrogênio amoniacal, com um aumento na zona fluvial de $0,12 \mathrm{mg} / \mathrm{L}$ (novembro de 2000) e outro na zona de transição de $0,08 \mathrm{mg} / \mathrm{L}$ (março de 2001), com uma concentração média de $0,03 \mathrm{mg} / \mathrm{L}$. Na zona fluvial foi obtida a maior concentração deste nutriente $(0,004 \mathrm{mg} / \mathrm{L})$ e as demais zonas apresentaram concentração de $0,003 \mathrm{mg} / \mathrm{L}$. 


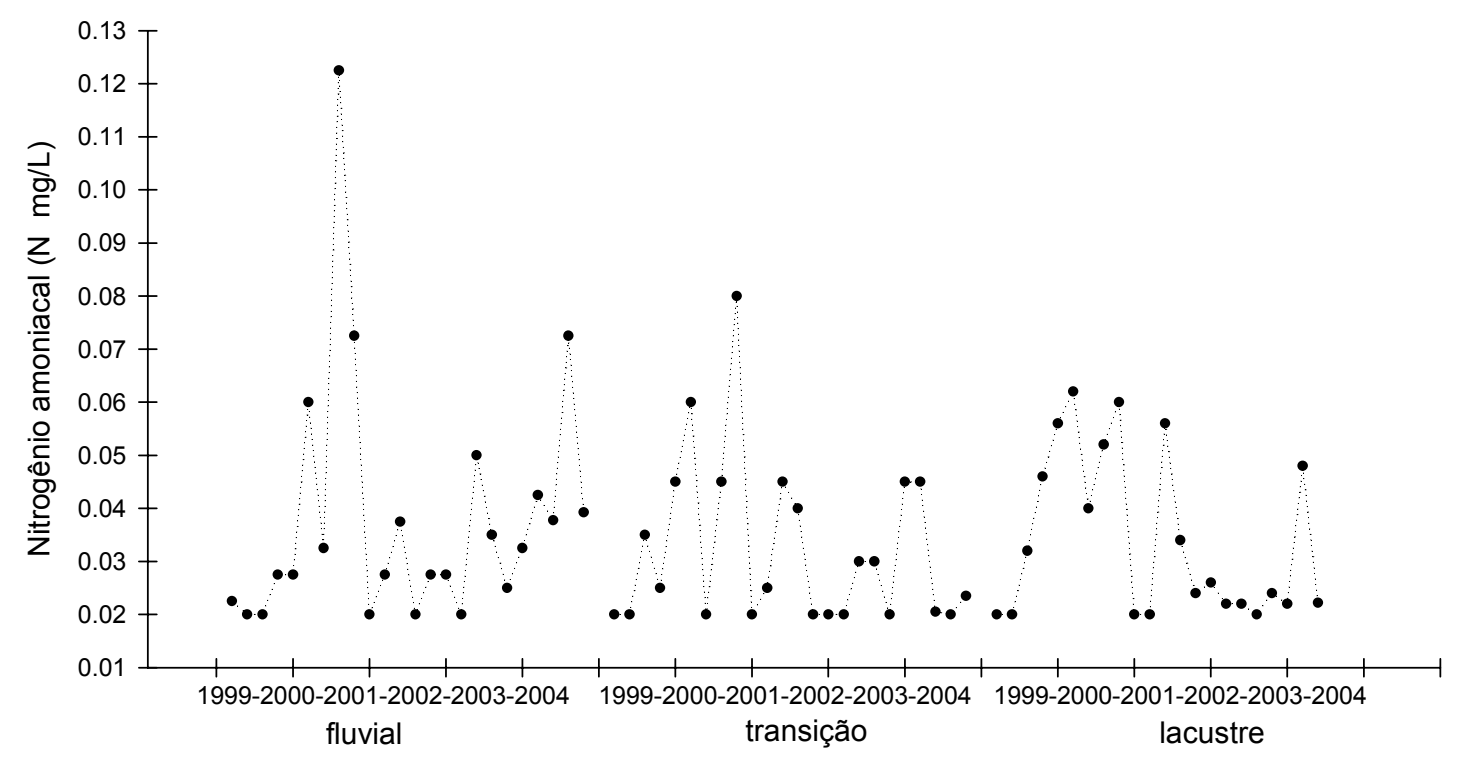

Figura 20: Variação da concentração de nitrogênio amoniacal (média trimestral) de acordo com as zonas do reservatório de Itaipu, para o período de 1999 a 2004.

\subsubsection{Fósforo total}

Na Figura 21 estão apresentados os valores de fósforo total, verificando-se aumentos em agosto de 2001 (0,12mg/L), na zona de transição, e novembro de 2004 $(0,11 \mathrm{mg} / \mathrm{l})$, na zona lacustre. A concentração média obtida foi de $0,03 \mathrm{mg} / \mathrm{L}$, sendo que nas zonas lacustre e de transição foram registrados os maiores valores médios $(0,003$ $\mathrm{mg} / \mathrm{L})$, seguido da zona lacustre $(0,002 \mathrm{mg} / \mathrm{L})$.

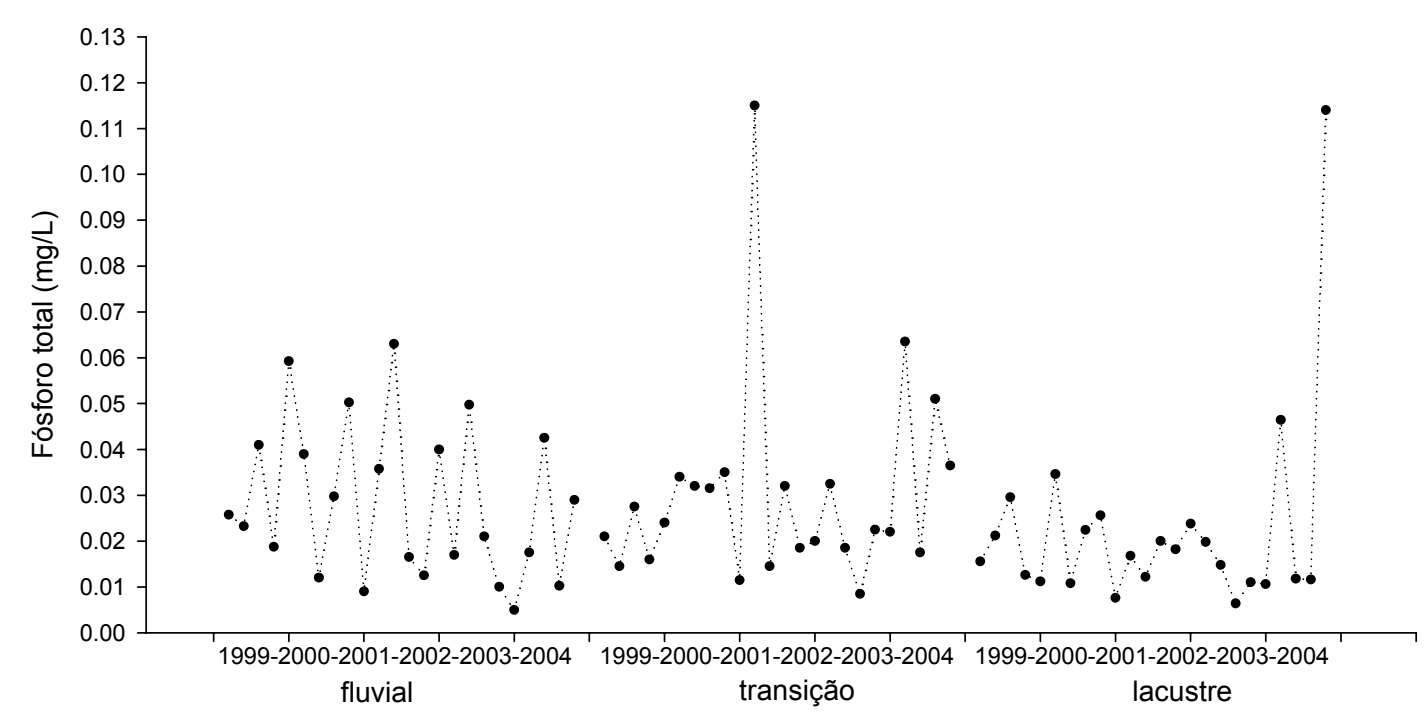

Figura 21: Variação da concentração de fósforo total (média trimestral) de acordo com as zonas do reservatório de Itaipu, para o período de 1999 a 2004. 


\subsubsection{Clorofila}

$\mathrm{Na}$ Figura 22 verifica-se que as zonas fluviais e lacustre apresentaram concentrações médias de clorofila- $a$ de $3,8 \mathrm{mg} / \mathrm{m}^{3}$ e $4,7 \mathrm{mg} / \mathrm{m}^{3}$, respectivamente. A zona de transição apresentou valores superiores aos observados nas demais zonas, com concentrações bem elevadas em dois meses $\left(153,5 \mathrm{mg} / \mathrm{m}^{3}\right.$ em agosto de 2001 e 70 $\mathrm{mg} / \mathrm{m}^{3}$ em novembro de 2000) e média de $21,9 \mathrm{mg} / \mathrm{m}^{3}$. A concentração média de clorofila no reservatório foi de $10,1 \mathrm{mg} / \mathrm{m}^{3}$.

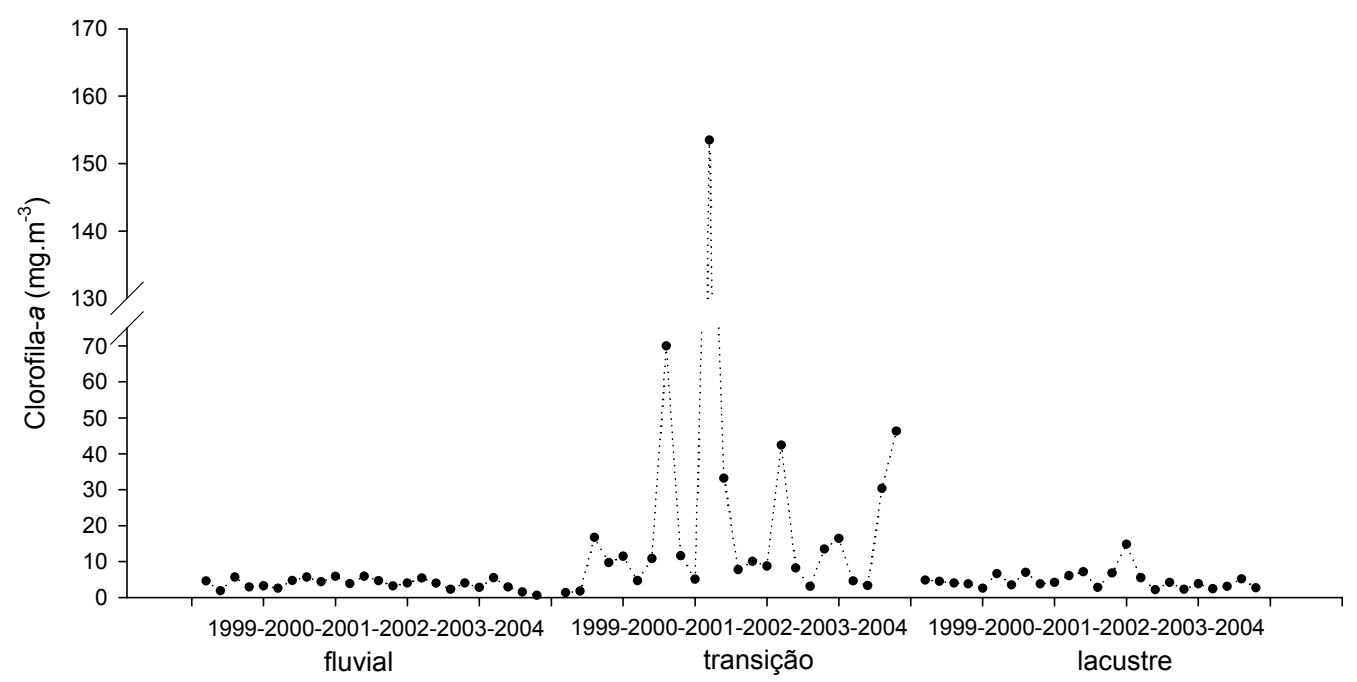

Figura 22: Variação da concentração de clorofila (média trimestral) de acordo com as zonas do reservatório de Itaipu, para o período de 1999 a 2004.

\subsubsection{Relações entre as variáveis limnológicas}

\subsubsection{Relação entre profundidade (disco de secchi), concentração de sólidos suspensos e concentração de turbidez}

A Figura 23 mostra a relação entre $\ln s$ e $\ln s o$ (1a) e a relação entre $\ln s$ e $\ln t(1 b)$. Estas podem ser tomadas como lineares, embora com bastante dispersão ao longo da reta de tendência. 


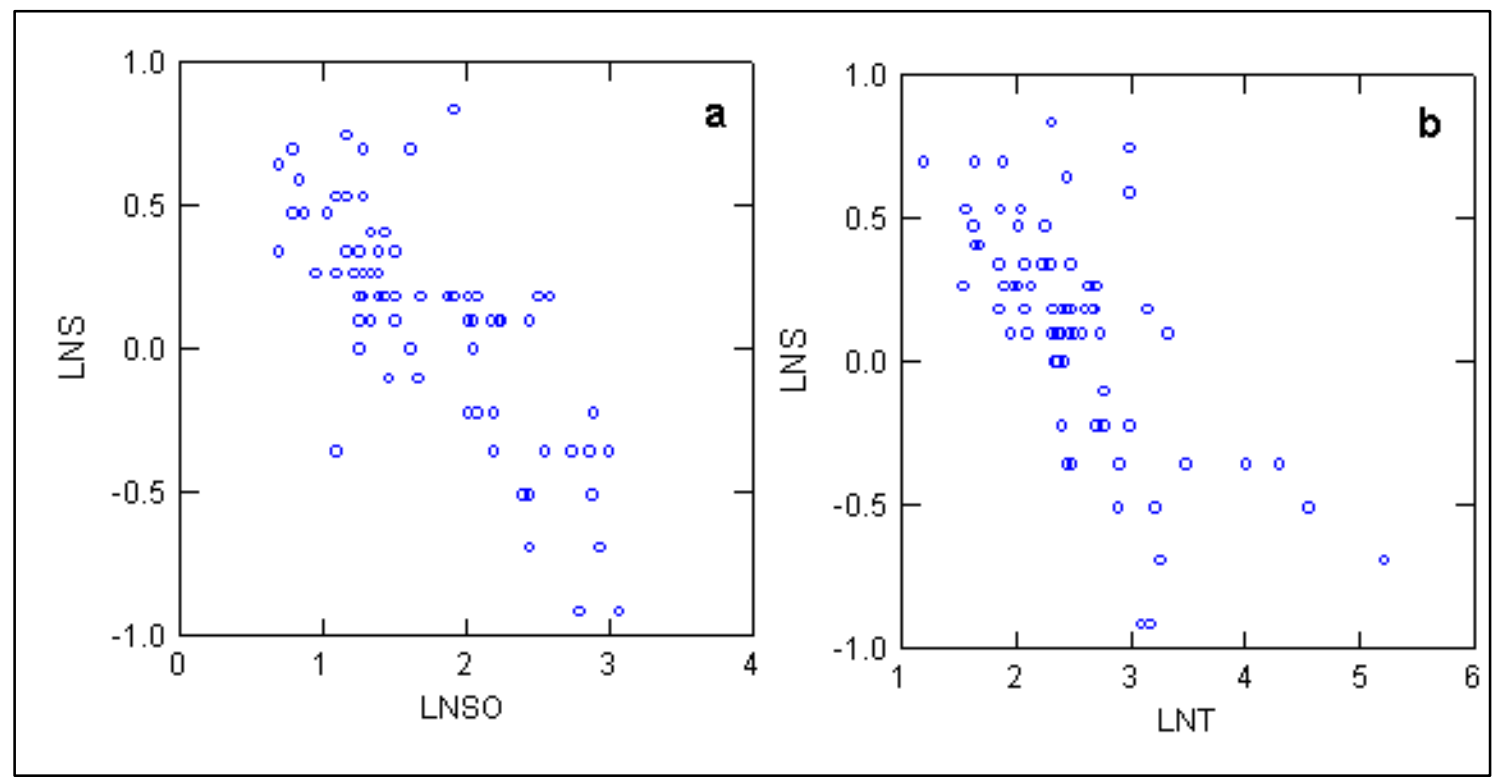

Figura 23: Relação entre (a) lns (logaritmo neperiano da profundidade de disco de secchi) e lnso (logaritmo neperiano da concentração de sólidos suspensos) e (b) lns (logaritmo neperiano da profundidade de disco de secchi) e $\ln t$ (logaritmo neperiano da concentração de turbidez).

Com base nos modelos completos testados, foram escolhidas quais as variáveis seriam utilizadas para os modelos de ANCOVA. No modelo $\ln s=\mu+Z R+\ln s o+\ln t+\varepsilon$ foram considerados $\ln s$ como variável dependente, a zona do reservatório $(Z R)$ como fator e as covariáveis (variáveis independentes) discriminados abaixo.

Fator:

$Z R$ : zona do reservatório (fluvial $=1 ;$ transição $=2 ;$ lacustre $=3$ ).

Covariáveis:

lnso: logaritmo neperiano da concentração de sólidos suspensos;

$\ln t$ : logaritmo neperiano da concentração de turbidez.

Para o modelo $\ln s=\mu+Z R+\ln s o+\ln t+\varepsilon$, o fator $Z R$ não foi significativo e foi eliminado do modelo, que daí se transformou numa regressão múltipla.

A Tabela 4 mostra o modelo final de regressão $\ln s=\mu+\ln s o+\ln t+\varepsilon$ que melhor explicou a relação entre a profundidade de disco de secchi, concentração de sólidos suspensos e concentração de turbidez. Apesar da transformação log-log, foi detectado um outlier (ponto discrepante da reta de ajuste da regressão), o qual não foi retirado por não se ter um critério justificável. 
Tabela 4: Resultados da análise de regressão aplicada no modelo $\ln s=\mu+\ln s o+\ln t+\varepsilon$, para os dados das variáveis limnológicas, onde $\ln t$ é o logaritmo neperiano da concentração de turbidez, lnso é o logaritmo neperiano da concentração de sólidos suspensos e $\varepsilon$ é o erro experimental.

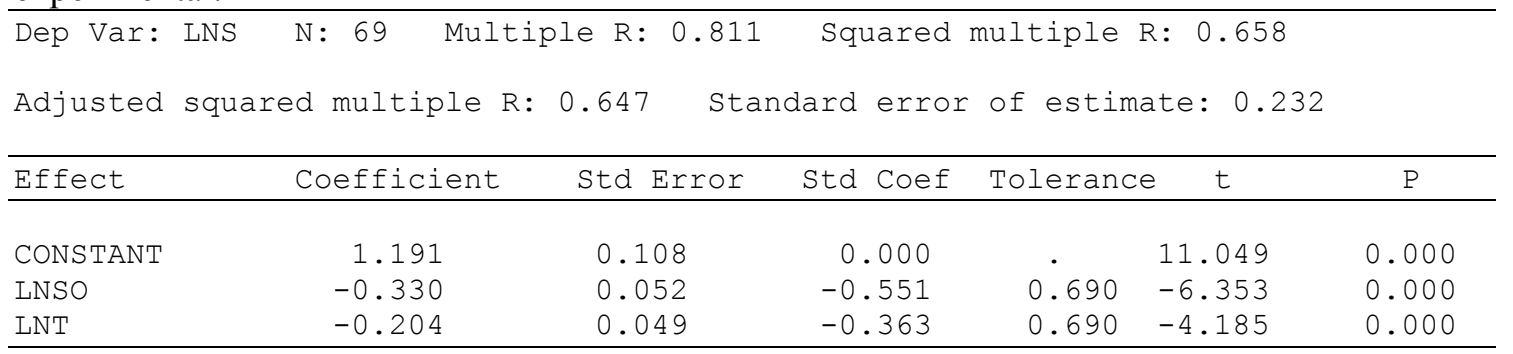

Na Figura 24 observam-se os pontos dispersos de modo aceitavelmente aleatório, isto é sem nenhum tipo de padrão aparente. A Figura 25 mostra o histograma dos resíduos para o modelo final da regressão. O valor da probabilidade do teste de normalidade de Lilliefors para os resíduos é $p=0,087$, aceitando-se a condição de normalidade $(\mathrm{p}>0,05)$.

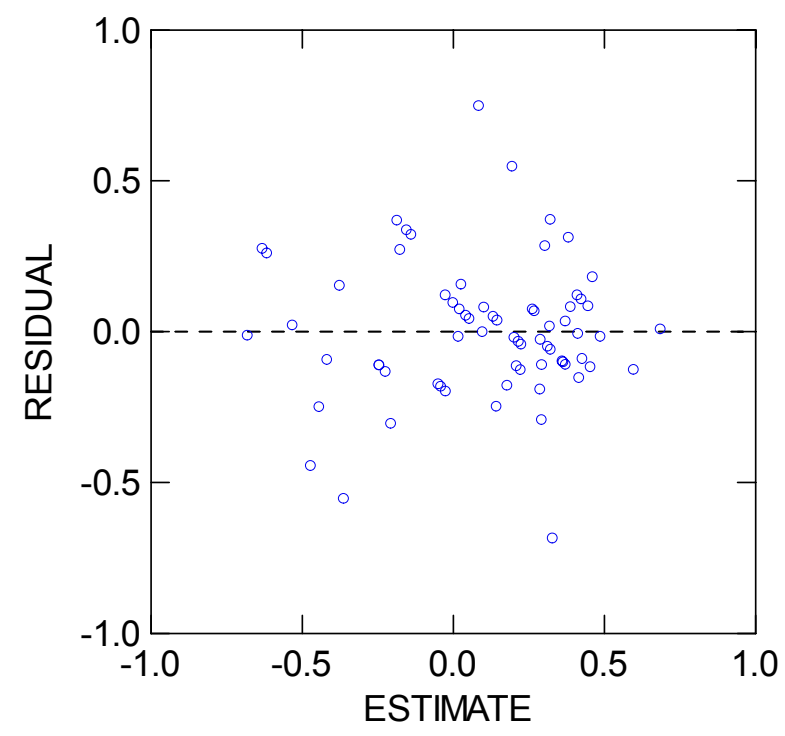

Figura 24: Distribuição dos resíduos studentizados em função dos valores estimados pelo modelo de regressão $\ln s=\mu+\ln s o+\ln t+\varepsilon$, para os dados das variáveis limnológicas, onde lnso é o logaritmo neperiano da concentração de sólidos suspensos, lnt é o logaritmo neperiano da concentração de turbidez e $\varepsilon$ é o erro experimental. 


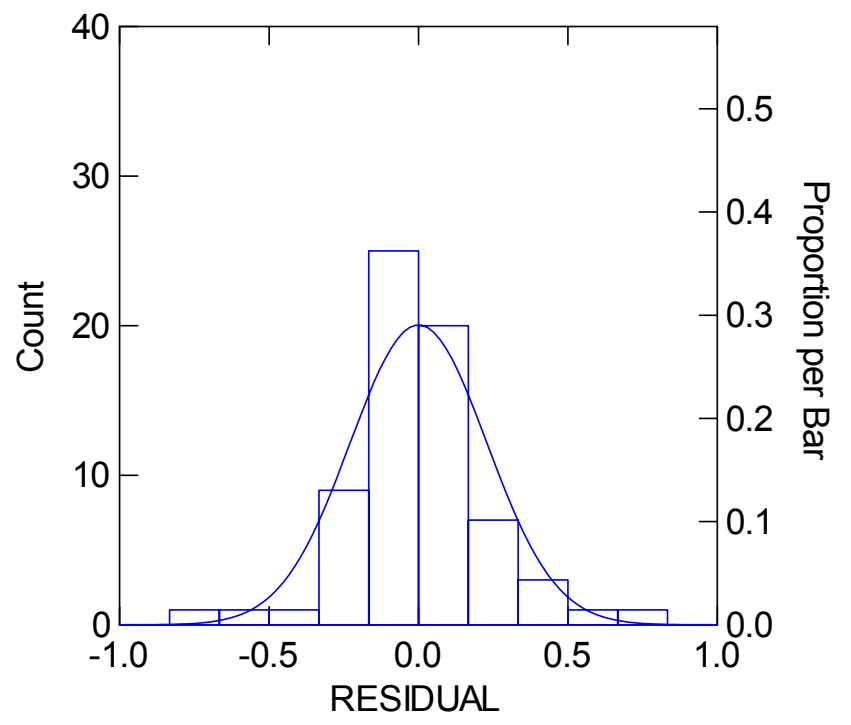

Figura 25: Histograma dos resíduos do modelo final da regressão $\ln s=\mu+\ln t+\ln s o+\varepsilon$, para os dados das variáveis limnológicas, onde $\ln t$ é o logaritmo neperiano da concentração de turbidez, lnso é o logaritmo neperiano da concentração de sólidos suspensos e $\varepsilon$ é o erro experimental.

Esta análise foi realizada com propósito de explicar a relação entre sólidos suspensos e turbidez sobre a transparência da água. Os resultados demonstram o efeito negativo e significativo destas variáveis independentes sobre a transparência da água, sendo o modelo explicado em $65 \%\left(\mathrm{R}^{2}=0,65 \%\right)$ (Tabela 1$)$.

\subsubsection{Relação entre concentração de clorofila, concentração de TKN e concentração de nitrogênio amoniacal}

A Figura 26 mostra a relação positiva entre $\operatorname{lncloro}$ e $\ln n$ _amo (a) e $\ln$ cloro e $\ln T K N(b)$. Estas podem ser tomadas como lineares, embora com bastante dispersão.

Com base nos modelos completos testados, foram escolhidas quais as variáveis seriam utilizadas para os modelos de ANCOVA. No modelo testado $\ln$ cloro $=\mu+Z R+\ln t k n+\ln n_{-}$amo $+\varepsilon$ foram considerados $\ln$ cloro a variável dependente, o fator zona do reservatório com três níveis, e as covariáveis (variáveis independentes) discriminados abaixo.

Fator:

$Z R$ : zona do reservatório (fluvial $=1 ;$ transição $=2 ;$ lacustre $=3$ ).

Covariáveis: 
$\ln n \_a m o: \operatorname{logaritmo}$ neperinao da concentração de nitrogênio amoniacal;

$\ln t k n$ : logaritmo neperiano de TKN.

O modelo $\ln$ cloro $=\mu+Z R+\ln t k n+\ln n_{-} a m o+Z R * \ln t k n+Z R * \ln n_{-} a m o+\varepsilon$ foi testado e as interações $Z R^{*} \ln n$ amo e $Z R^{*} \ln t k n$ não foram significativas a $5 \%$; as retas foram consideradas paralelas e essas interações foram sucessivamente eliminadas do modelo, uma a uma. Na Tabela 5 é apresentado o modelo final da ANCOVA $\ln$ cloro $=\mu+Z R+\ln t k n+\ln n_{-} a m o+\varepsilon$.

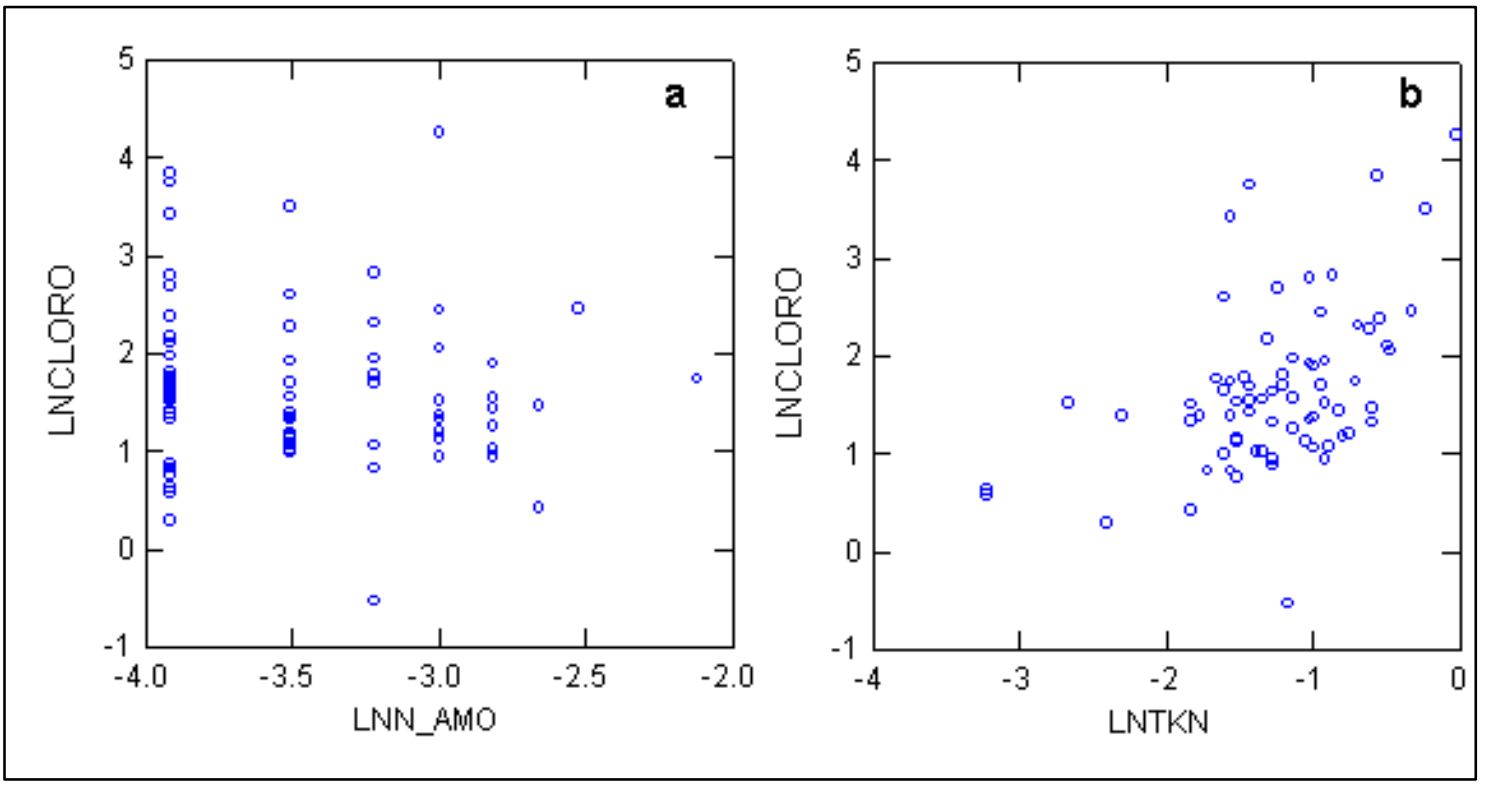

Figura 26: Relação entre lncloro e $\ln n$ amo (a) e $\ln$ cloro e $\ln T K N$ (b) (lncloro é o logaritmo neperiano da concentração de clorofila, $\ln n$ amo é o logaritmo neperian.o da concentração de nitrogênio amoniacal e lnTKN é logaritmo neperiano de TKN).

O resultado da ANCOVA apresentado acima indica não só o efeito da concentração de TKN e de nitrogênio amoniacal, mas também das zonas do reservatório sobre as concentrações de clorofila. Para o modelo final foi feita uma análise de resíduos. Na Figura 27 observam-se os pontos dispersos de modo aleatório, sem que haja relação entre a distribuição dos resíduos studentizados e os valores estimados e a Figura 28 mostra o histograma dos resíduos do modelo final da ANCOVA. Os valores de probabilidade de Lilliefors para os resíduos foram de 0,290, aceitando-se a condição de normalidade $(\mathrm{p}>0,05)$. 
Tabela 5 Resultados da ANCOVA aplicada no modelo $\ln$ cloro $=\mu+Z R+\ln t k n+\ln n_{-} a m o+\varepsilon$, para os dados das variáveis limnológicas, onde $Z R$ é a zona do reservatório ( $1=$ fluvial; $2=$ transição; $3=$ lacustre $)$ e $\ln t k n$ é o logaritmo neperiano da concentração de TKN, $\ln n$ _amo é o logaritmo neperiano da concentração de nitrogênio amoniacal e $\varepsilon$ é o erro experimental.

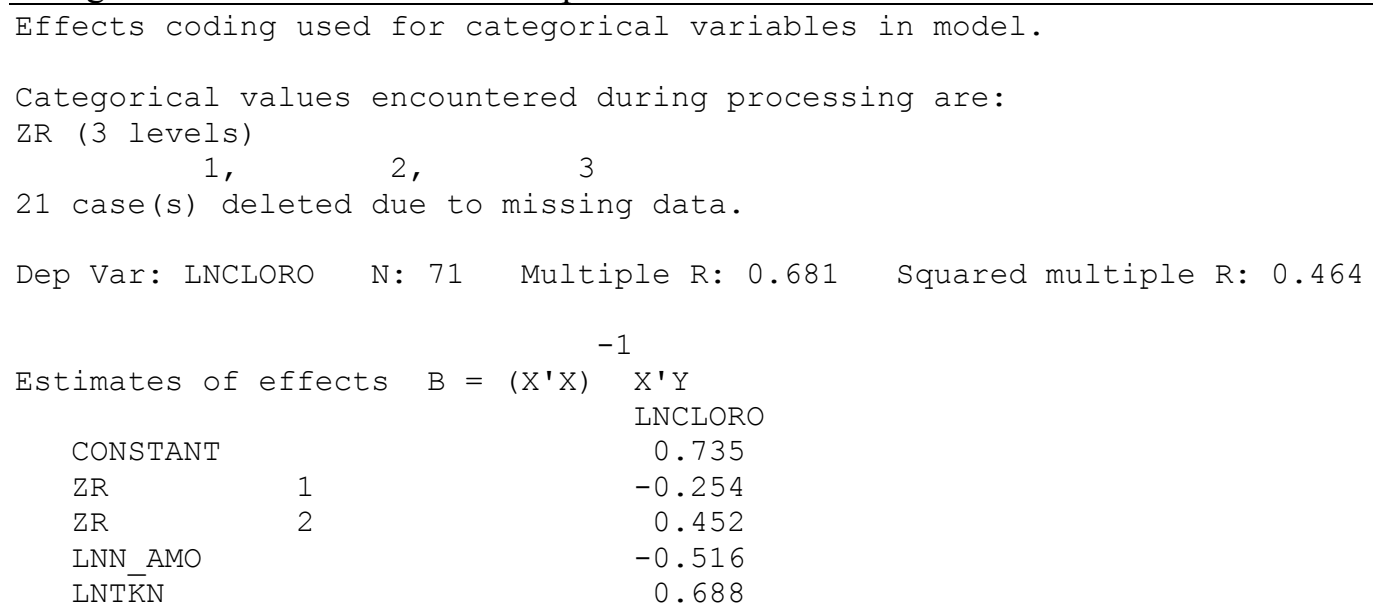

\begin{tabular}{lrrrrr}
\hline $\begin{array}{l}\text { Analysis of Variance } \\
\text { Source }\end{array}$ & & & & \\
Sum-of-Squares & df & Mean-Square & F-ratio & P \\
\hline ZR & 6.492 & 2 & 3.246 & 8.161 & 0.001 \\
LNN_AMO & 2.934 & 1 & 2.934 & 7.375 & 0.008 \\
LNTKN & 8.181 & 1 & 8.181 & 20.568 & 0.000 \\
Error & 26.252 & 66 & 0.398 & & \\
\hline
\end{tabular}

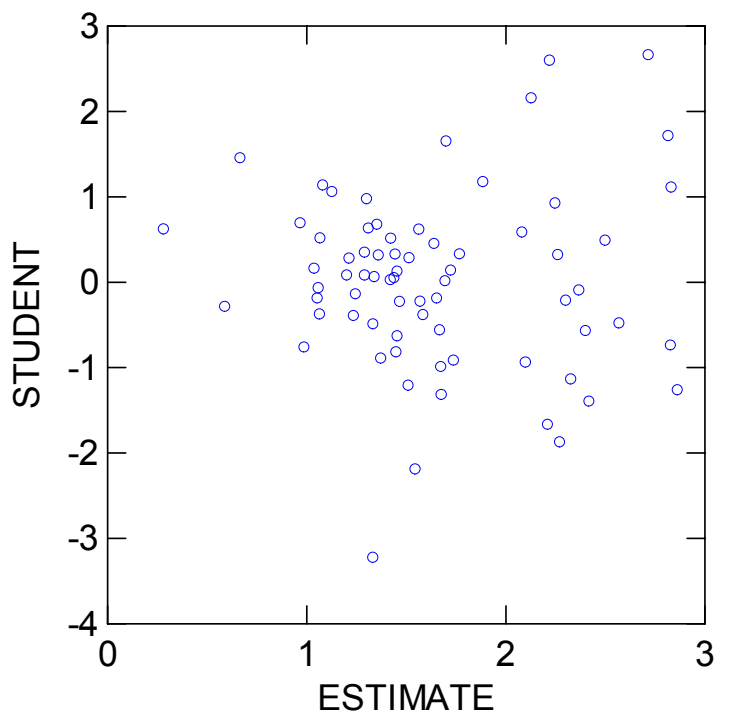

Figura 27: Distribuição dos resíduos studentizados em função dos valores estimados pelo modelo ANCOVA $\ln$ cloro $=\mu+Z R+\ln t k n+\ln n_{-} a m o+\varepsilon$, para os dados das variáveis limnológicas, onde $Z R$ é a zona do reservatório (1= Fluvial, $2=$ Transição, $3=$ Lacustre), $\ln t k n$ é o logaritmo da concentração de TKN, lnn_amo é o logaritmo neperiano da concentração de nitrogênio amoniacal e $\varepsilon$ é o erro experimental. 


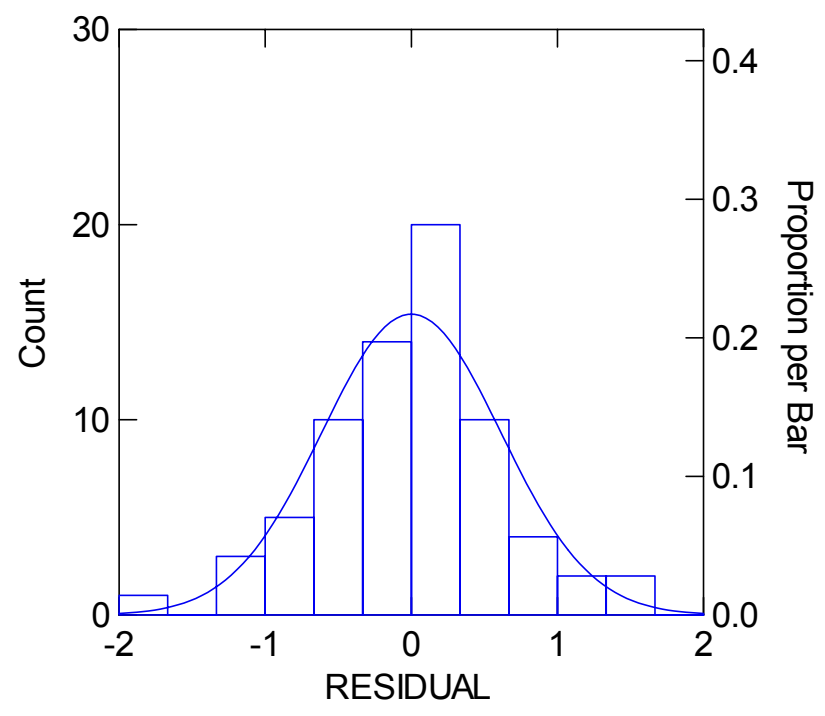

Figura 28: Histograma dos resíduos do modelo final da ANCOVA $\ln$ cloro $=\mu+Z R+\ln T K N+\ln n \_$amo $+\varepsilon$, para os dados das variáveis limnológicas, onde $Z R$ é a zona do reservatório (1= Fluvial, 2= Transição, 3= Lacustre), lntkn é o logaritmo neperiano da concentração de TKN, $\ln n \_a m o$ é o logaritmo neperiano da concentração de nitrogênio amoniacal e $\varepsilon$ é o erro experimental.

O teste de comparação entre as médias mostrou não haver diferença estatística para as concentrações de clorofila, entre as zonas do reservatório, quando comparadas duas a duas, tanto em relação à concentração de $\mathrm{TKN}$, quanto em relação à concentração de nitrogênio amoniacal (Tabela 6). Na Figura 29 estão representadas as médias ajustadas das concentrações de clorofila.

Tabela 6: Teste a posteriori entre as médias ajustadas de lncianoba (logaritmo neperiano da concentração de cianobactérias) obtidas a partir do modelo final da ANCOVA $\ln$ cloro $=\mu+Z R+\ln T K N+\ln n_{-}$amo $+\varepsilon$ para as três zonas do reservatório (1= Fluvial; $2=$ Transição; $3=$ Lacustre). Os números entre parêntesis representam os antilogaritmos das médias ajustadas (concentração de clorofila), em escala aritmética.

\begin{tabular}{c|c|c}
\hline $\begin{array}{c}\text { Comparação entre locais para } \\
\text { TKN }\end{array}$ & $\begin{array}{c}\text { Média ajustada da concentração de } \\
\text { clorofila } \\
\ln \overline{\text { cloro }}(\text { antilog ln cloro }) \pm \mathrm{ep}\end{array}$ & $\begin{array}{c}\text { Teste } \\
\text { LSD }\end{array}$ \\
\hline 1 e 2 & $1,398(4,95) \pm 0,134$ & $1,2829 \mathrm{~ns}$ \\
\hline 1 e 3 & $2,104(8,20) \pm 0,134$ & $0,0927 \mathrm{~ns}$ \\
\hline 2 e 3 & $1,454(4,28) \pm 00,132$ & $1,2197 \mathrm{~ns}$ \\
\hline
\end{tabular}

\begin{tabular}{c|c|c}
\hline $\begin{array}{c}\text { Comparação entre locais para } \\
\text { nitrogênio amoniacal }\end{array}$ & $\begin{array}{c}\text { Média ajustada da concentração de } \\
\text { clorofila } \\
\ln \text { cloro }(\text { antilog } \ln \text { cloro }) \pm \mathrm{ep}\end{array}$ & $\begin{array}{c}\text { Teste } \\
\boldsymbol{L S D} \boldsymbol{D}\end{array}$ \\
\hline 1 e 2 & $1,398(4,95) \pm 0,134$ & $0,3859 \mathrm{~ns}$ \\
\hline 1 e 3 & $2,104(8,20) \pm 0,134$ & $0,0309 \mathrm{~ns}$ \\
\hline 2 e 3 & $1,454(4,28) \pm 00,132$ & $0,3520 \mathrm{~ns}$ \\
\hline
\end{tabular}




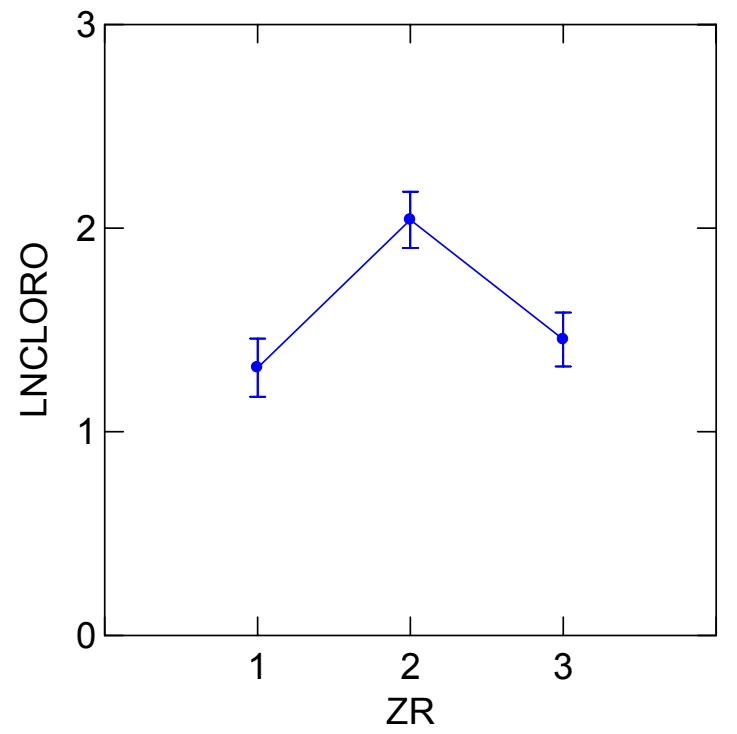

Figura 29: Médias ajustadas de lncloro para as zonas do reservatório, com 1 = Fluvial, $2=$ Transição e 3 = Lacustre. As barras verticais indicam o erro padrão da média ajustada.

Tais resultados demonstram a importância dos nutrientes nas concentrações de clorofila- $a$ no reservatório. O modelo prediz $46 \%\left(\mathrm{r}^{2}=0,464\right)$ da relação das variáveis independentes sobre a clorofila- $a$ (Tabela 5).

\subsubsection{Relação entre concentração de cianobactérias e concentração de TKN}

A Figura 30 mostra a relação positiva entre $\ln$ ciano e $\ln T K N$, que pode ser tomada como linear, embora com acentuada dispersão ao longo da reta de tendência. 


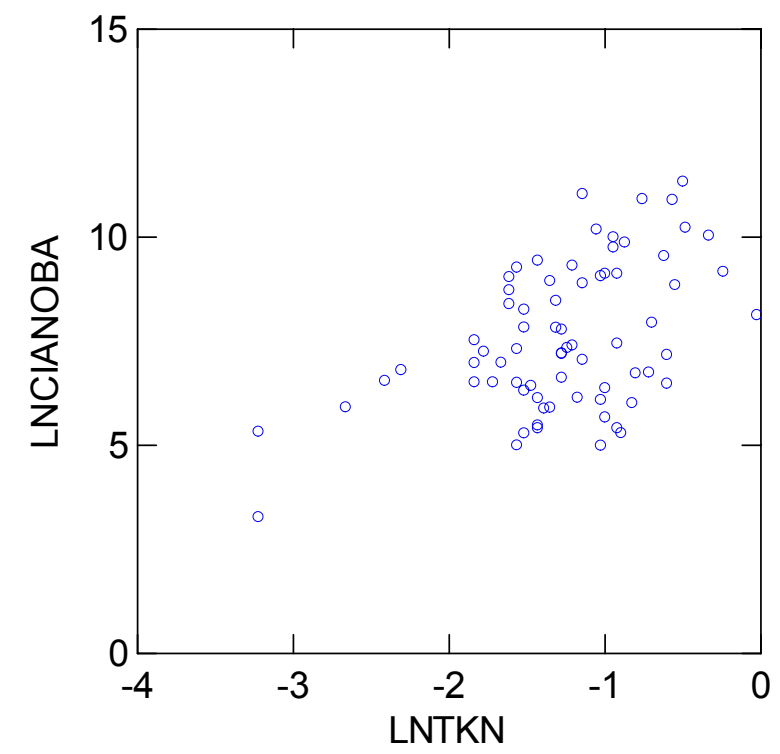

Figura 30: Relação entre lncianoba (logaritmo neperiano da concentração de cianobactérias) e $\ln T K N$ (logaritmo neperiano de TKN).

Com base nos modelos completos testados, foram escolhidas quais as variáveis seriam utilizadas para os modelos de ANCOVA. No modelo $\ln$ cianoba $=\mu+Z R+\ln t k n+\varepsilon$ testado foram considerados lncianoba a variável dependente, o fator zona do reservatório com três níveis e a covariável $\ln t k n$ :

Fatores:

$Z R$ : zona do reservatório (fluvial $=1 ;$ transição $=2$; lacustre $=3$ ).

Covariável:

$\ln t k n$ : logaritmo neperiano da concentração de TKN.

Após as análises preliminares, o modelo da ANCOVA testado foi $\ln$ cianoba $=\mu+Z R+\ln t k n+Z R^{*} \ln t k n+\varepsilon$, o resultado da interação $Z R^{*} \ln t k n$ não foi significativo a $5 \%$, as retas foram consideradas paralelas e essa interação foi eliminada do modelo. O modelo final $\ln$ cianoba $=\mu+Z R+\ln T K N+\varepsilon$ que melhor explicou a relação entre as concentrações de cianobactérias, de TKN e zonas do reservatório está apresentado na Tabela 7.

O resultado da ANCOVA apresentado acima indica não só o efeito da concentração de TKN, mas também das zonas do reservatório sobre as concentrações de cianobactérias. Para o modelo final foi feita uma análise de resíduos. Na Figura 31 observam-se os pontos dispersos de modo aleatório, sem que haja relação entre a distribuição dos resíduos studentizados e os valores estimados e a Figura 32 mostra o 
histograma dos resíduos do modelo final. Os valor da probabilidade de Lilliefors para os resíduos foi $\mathrm{p}=0,938$, aceitando-se a condição de normalidade.

Tabela 7: Resultados da ANCOVA aplicada no modelo $\ln$ cianoba $=\mu+Z R+\ln T K N+\varepsilon$, para os dados das variáveis limnológicas, onde $Z R$ é a zona do reservatório $(1=$ fluvial; $2=$ transição; $3=$ lacustre) e $\ln T K N$ é o logaritmo neperiano de TKN e $\varepsilon$ é o erro experimental.

Effects coding used for categorical variables in model.

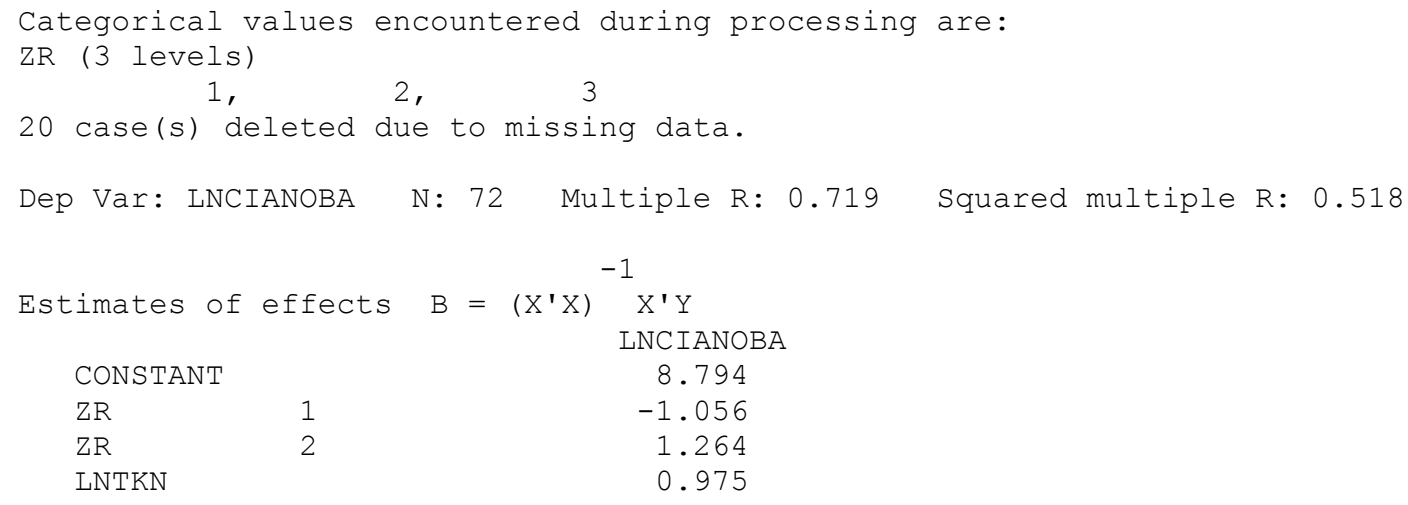

\begin{tabular}{lrrrrr}
\hline Source & Sum-of-Squares & df & Mean-Square & F-ratio & P \\
\hline ZR & 61.090 & 2 & 30.545 & 20.058 & 0.000 \\
LNTKN & 21.378 & 1 & 21.378 & 14.038 & 0.000 \\
Error & 103.552 & 68 & 1.523 & & \\
\hline
\end{tabular}

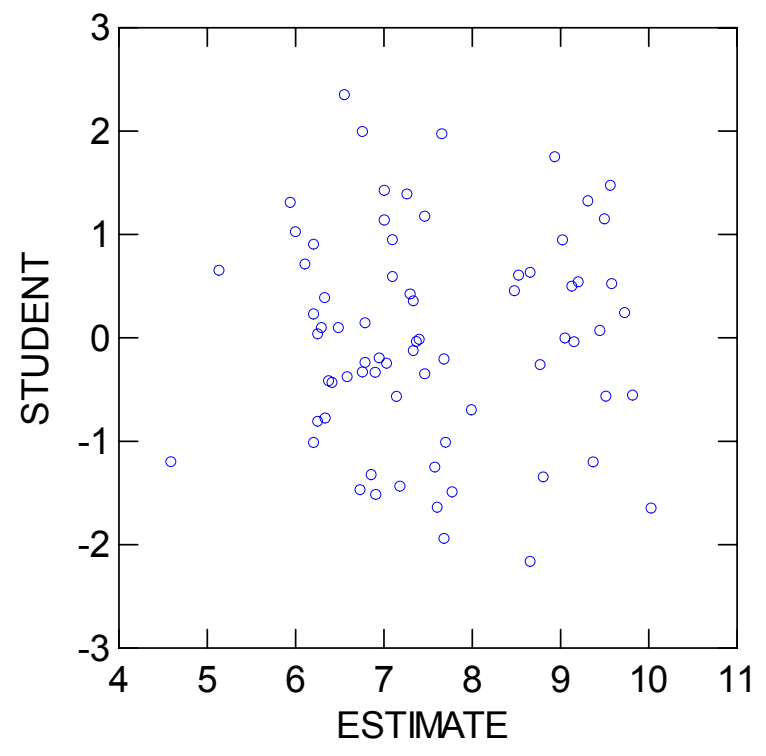

Figura 31: Distribuição dos resíduos studentizados em função dos valores estimados pelo modelo ANCOVA $\ln$ cianoba $=\mu+Z R+\ln T K N+\varepsilon$, para os dados das variáveis limnológicas, onde $Z R$ é a zona do reservatório ( $1=$ Fluvial, $2=$ Transição, $3=$ Lacustre), $\ln T K N$ é o logaritmo de TKN e $\varepsilon$ é o erro experimental. 


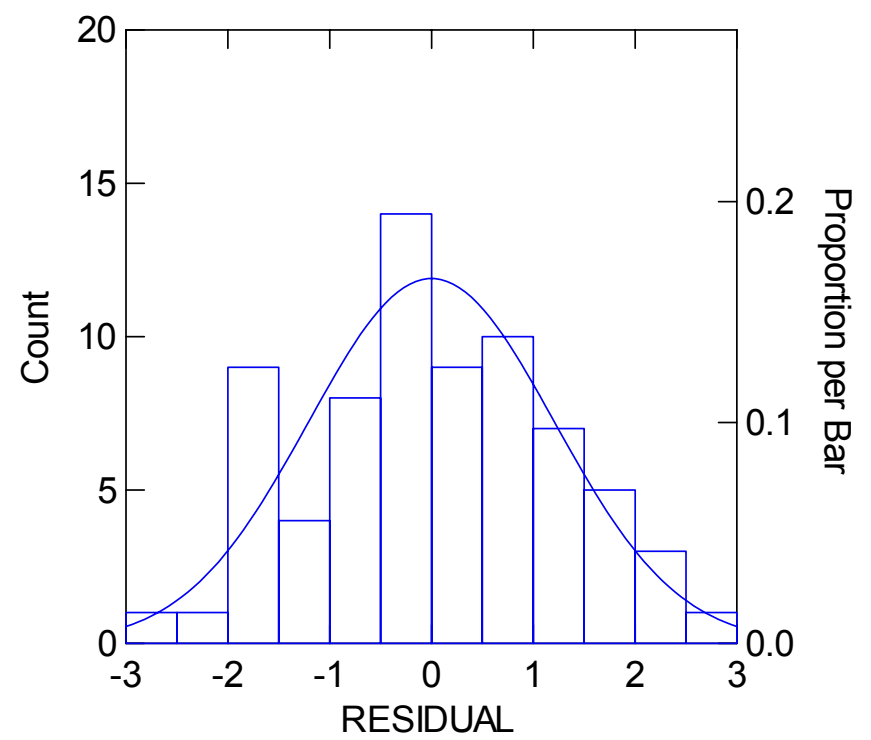

Figura 32: Histograma dos resíduos do modelo final da ANCOVA $\ln$ cianoba $=\mu+Z R+\ln T K N+\varepsilon$, para os dados das variáveis limnológicas, onde $Z R$ é a zona do reservatório ( $1=$ Fluvial, $2=$ Transição, $3=$ Lacustre), $\ln T K N$ é o logaritmo neperiano de $\mathrm{TKN}$ e $\varepsilon$ é o erro experimental.

O teste de comparação entre as médias das concentrações de cianobactérias (Tabela 8) mostrou haver diferenças estatísticas entre as zonas Fluvial e Transição (1 e 2), a 5 e 1\%, com concentrações médias de 673,84 org./ml e 6866,83 org./ml, respectivamente. Entre as zonas Transição e Lacustre (2 e 3) também houve diferença estatística entre as concentrações (5\%) e esta teve média de 1571,84 org./ml. Não houve diferença entre as médias das concentrações para as zonas Fluvial e Lacustre (1 e 3). Na Figura 33 estão representadas as médias ajustadas das concentrações de cianobactérias.

Tabela 8: Teste a posteriori entre as médias ajustadas de lncianoba (logaritmo neperiano da concentração de cianobactérias) obtidas a partir do modelo final da ANCOVA $\ln$ cianoba $=\mu+Z R+\ln T K N+\varepsilon$ para as três zonas do reservatório (1= Fluvial; 2= Transição; $3=$ Lacustre). Os números entre parêntesis representam os antilogaritmos das médias ajustadas (concentração de cianobactérias), em escala aritmética.

\begin{tabular}{c|c|c}
\hline $\begin{array}{c}\text { Comparação } \\
\text { entre locais }\end{array}$ & $\begin{array}{c}\text { Média ajustada da concentração } \\
\text { de cianobactérias } \\
\ln \text { cianoba }(\text { antilog } \operatorname{lncianoba}) \pm \mathrm{ep}\end{array}$ & $\begin{array}{c}\text { Teste } \\
\boldsymbol{L S D}\end{array}$ \\
\hline 1 e 2 & $6,513(673,84) \pm 0,256$ & $-3,668^{* *}$ \\
\hline 1 e 3 & $8,833(6866,83) \pm 0,258$ & $-1,247 \mathrm{~ns}$ \\
\hline 2 e 3 & $7,360(1571,84) \pm 0,252$ & $2,406^{*}$ \\
\hline
\end{tabular}




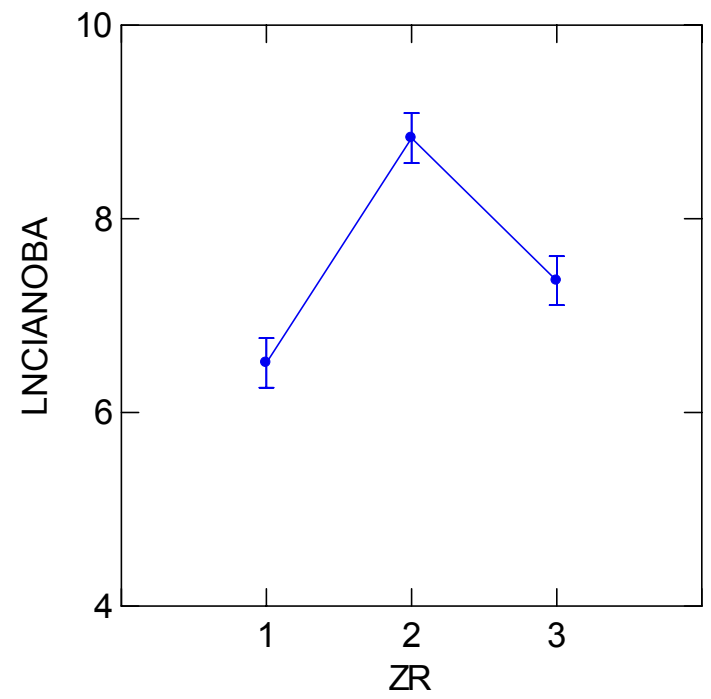

Figura 33: Médias ajustadas de lncianoba para as zonas do reservatório, com $1=$ Fluvial, $2=$ Transição e 3 = Lacustre. As barras verticais indicam o erro padrão da média ajustada.

\subsubsection{8. Índice de estado trófico}

Na Figura 34 observa-se um decréscimo do Índice de Estado do Trófico conciderando a transparência da água na zona fluvial e nas demais zonas, obtendo-se um valor médio de 52,93 (com pico de 64,92), decrescendo para 50,91 na zona de transição e 44,53 na zona lacustre. Na zona de transição verificou-se um aumento em novembro de $2004(61,51)$. O valor médio obtido foi de 64,92. 


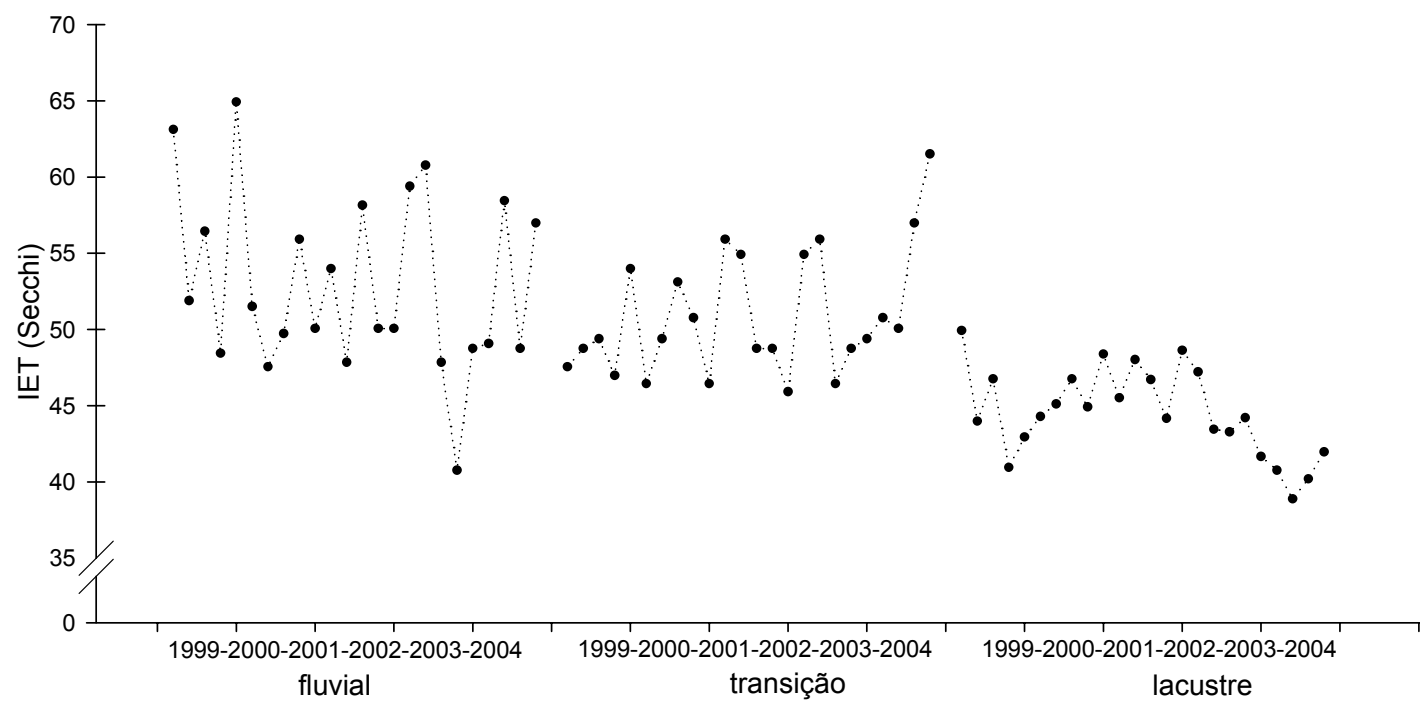

Figura 34: Variação do IET (Secchi) (média trimestral) no reservatório de Itaipu, para o período de 1999 a 2004

Na Figura 35 observa-se que a zona de transição apresentou índices mais elevados, com média de 54,83 e valor máximo de 81,04 em agosto de 2001, e as demais zonas apresentaram média em torno de 44,03. No reservatório observou-se um valor médio de 47,63 para as três zonas estudadas, considerando a concentração da clorofila.

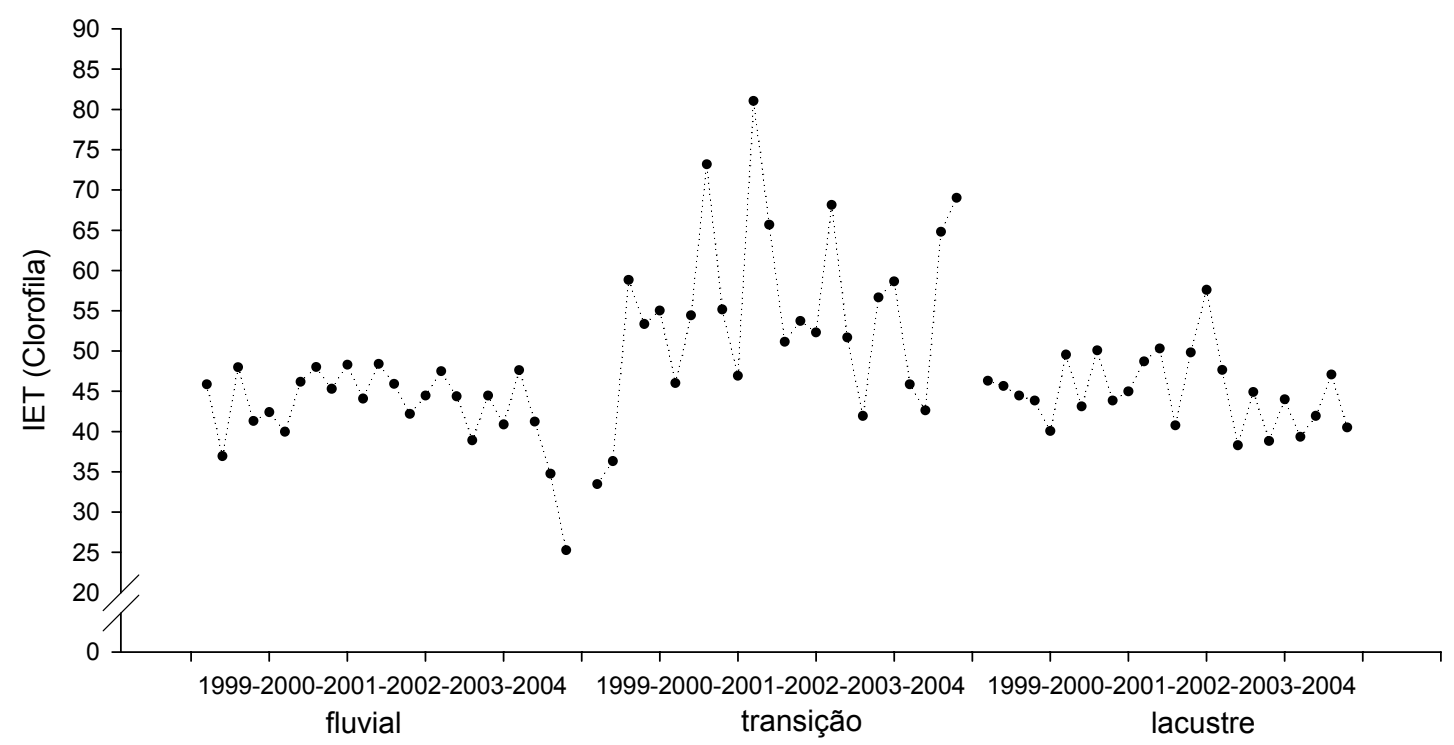

Figura 35: Variação do IET (clorofila) (média trimestral) no reservatório de Itaipu para o período de 1999 a 2004.

Os resultados do IET utilizando os valores de fósforo total estão apresentados na Figura 36. A zona fluvial apresentou um valor médio de 42,12 e na zona de transição 
o valor médio obtido foi de 43,31. Na zona fluvial foi registrado um valor máximo de 56,50 e a zona lacustre foi a que apresentou a menor média entre todas as zonas $(37,97)$.

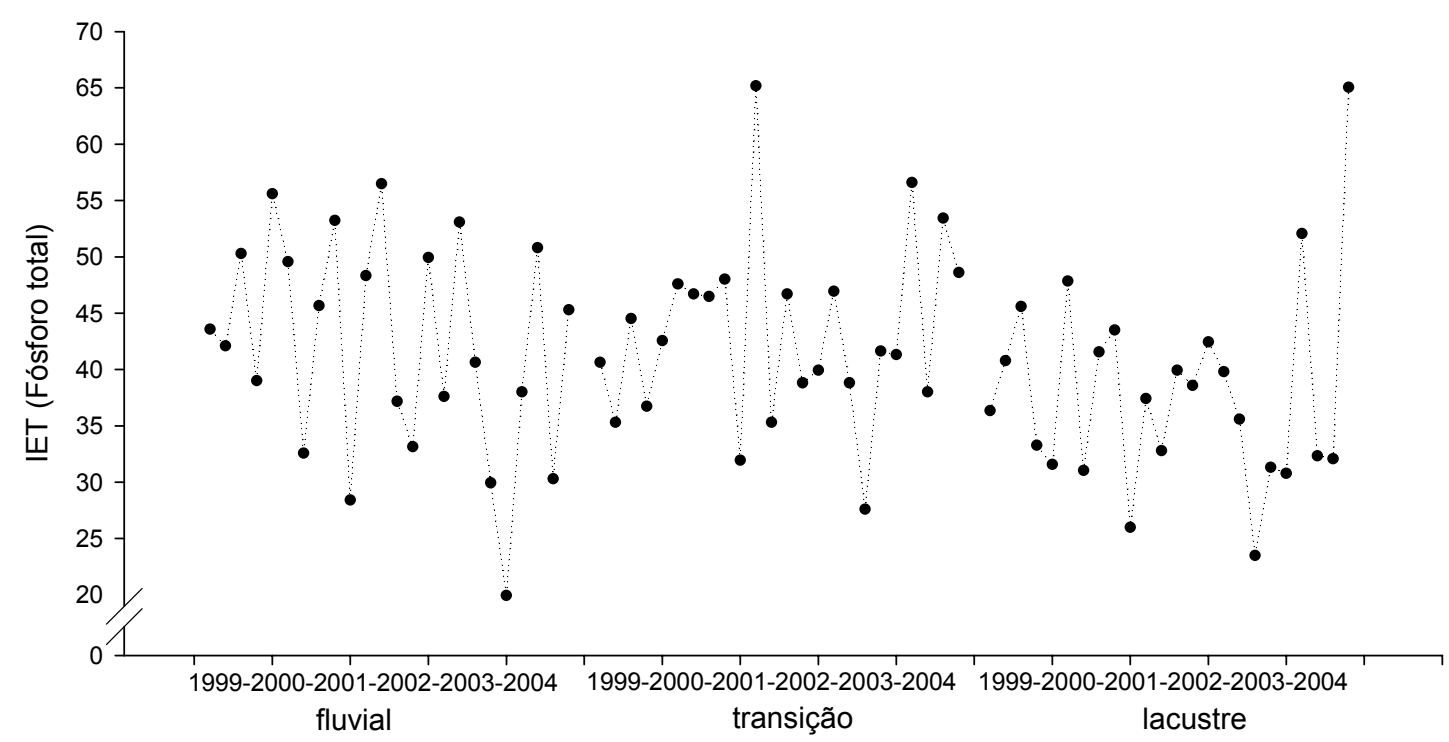

Figura 36: Variação do IET (fósforo total) (média trimestral) no reservatório de Itaipu para o período de 1999 a 2004

Na Figura 37 são apresentados os valores da média ponderada (disco de secchi, clorofila e P.total) do Índice de Estado Trófico. A zona de transição foi a que apresentou o maior valor médio $(49,44)$, com maior valor $(69,67)$ em agosto de 2001 . A zona fluvial apresentou valor médio de 52,19, com menor valor $(34,08)$ em novembro de 2003. A zona lacustre apresentou a menor média entre as zonas do reservatório, com valor médio de 36,02 .

O cálculo da média de IET para todo o reservatório foi de 45,40, sendo classificado como Mesotrófico. Este valor, contudo, é próximo ao valor limite de águas classificadas como Oligotróficas $(\geq 44)$. 


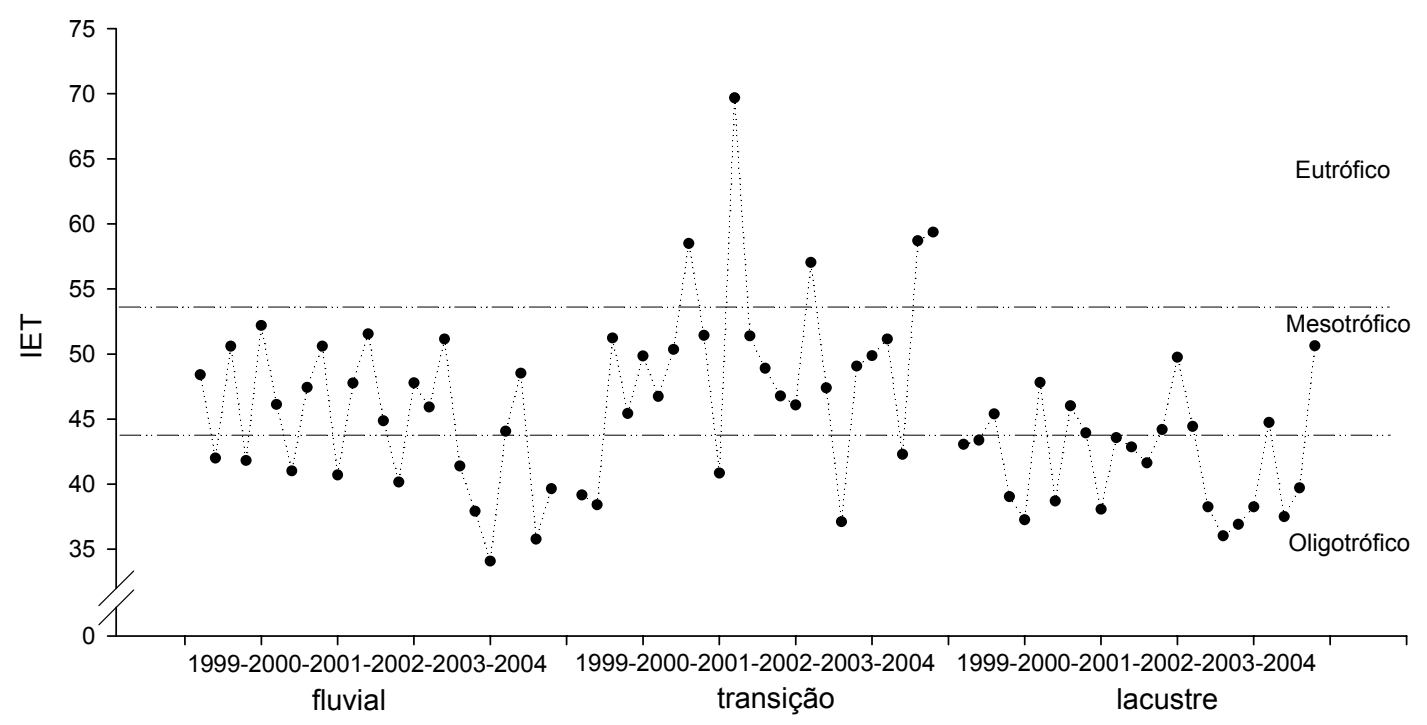

Figura 37: Variação do IET (médio) (média trimestral) no reservatório de Itaipu, para o período de 1999 a 2004.

\subsection{Composição, densidade e abundância relativa do fitoplâncton}

$\mathrm{Na}$ Tabela 9 encontram-se discriminados os gêneros e espécies identificadas durante o período de estudo. Na Figura 38 observa-se a dominância de Cyanophyceae praticamente em todo o reservatório, com a maior média (18941 org./mL) na zona de transição, com o maior valor (82384 org./mL) ocorrendo em novembro de 2002. A zona fluvial foi a que apresentou a menor média (1400 org. $/ \mathrm{mL})$ e a menor densidade, com 26,25org./mL. A zona lacustre apresentou média de 2972org./mL e o reservatório teve média total de 7771 org. $/ \mathrm{mL}$, entre as estações.

As algas pertencente a Classe Chlorophyceae corresponderam ao segundo grupo mais abundante no reservatório e na zona de transição foram registradas densidades mais elevadas, com maior valor de 10011 org./mL em março de 2004, e concentração média de $497 \mathrm{org} . / \mathrm{mL}$. No reservatório a densidade média entre as zonas fluvial, transição e lacustre foi de 234org./mL e em agosto de 1999 não foi registrada a presença de nenhum organismo desta classe.

As algas pertencentes à classe Bacillariophyceae apresentaram densidade média, para todo reservatório, de $212 \mathrm{org} . / \mathrm{mL}$. Este grupo foi mais abundante na zona de transição, com densidade média de 232 org. $/ \mathrm{mL}$. As menores densidades também 
foram encontradas na zona de transição, com ausências de ocorrência em novembro de 2002 e agosto de 2004.

Em relação aos fitoflagelados, a maior densidade média foi obtida na zona lacustre (203org./mL), com valor máximo de 733org./mL. Na zona de transição foi verificada a maior densidade (771 org. $/ \mathrm{mL}$ ) em março de 2003, com um valor médio de 184org./mL.

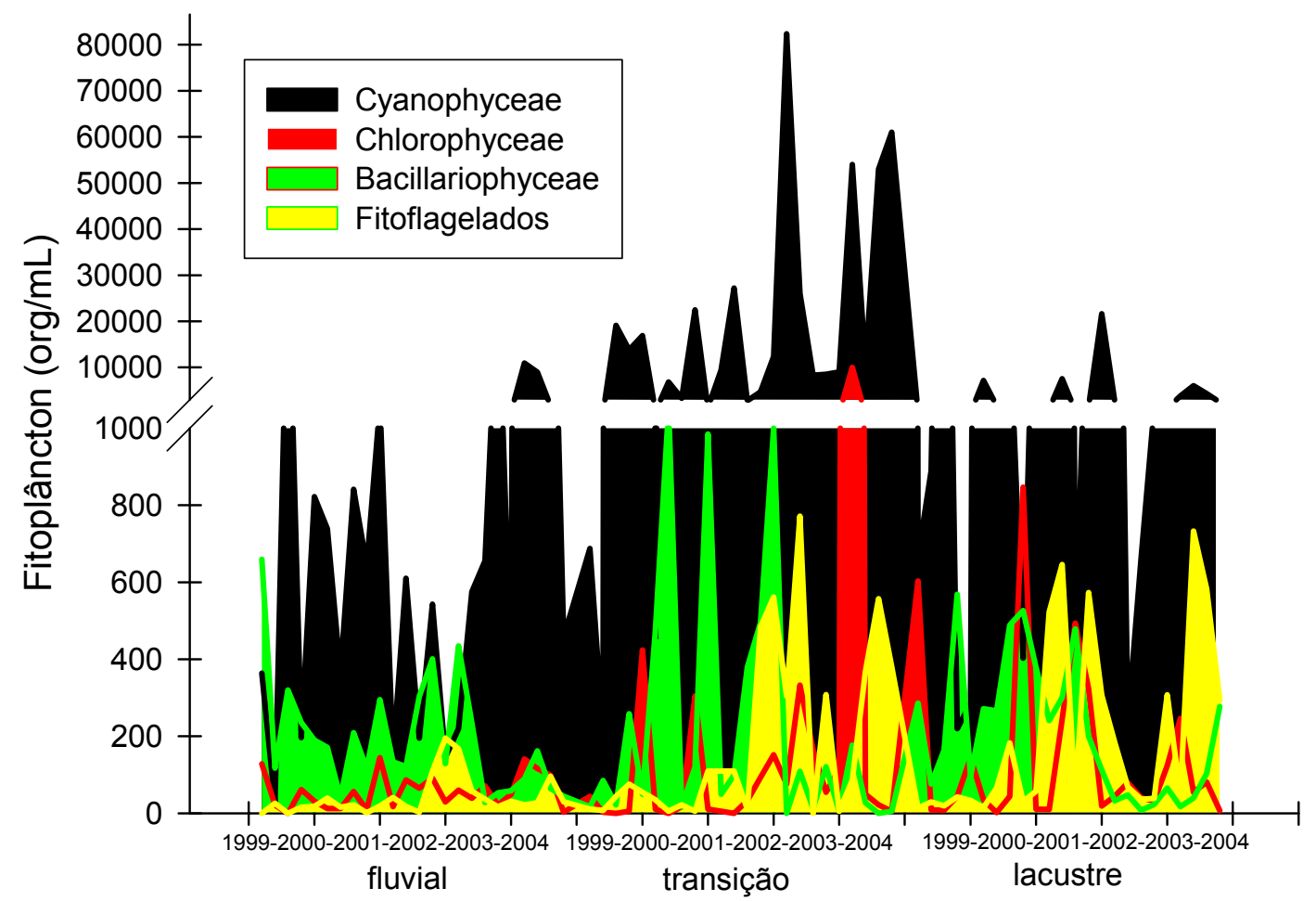

Figura 38: Variação da comunidade fitoplânctônica de acordo com as zonas do reservatório de Itaipu, para o período de 1999 a 2004.

Tabela 9: Relação dos táxons de fitoplâncton identificados no reservatório de Itaipu durante o período de estudo.

\begin{tabular}{llll}
\hline Cyanophyceae & Chlorophyceae & Bacillariophyceae & Fitoflagelados \\
\hline Anabaena $\mathrm{sp}$ & Actinastrum $\mathrm{spp}$ & Achnanthes $\mathrm{spp}$ & Chilomonas $\mathrm{spp}$ \\
A. spiroides & Ankistrodesmus $\mathrm{spp}$ & A. minutissima & C. acuta \\
Aphanocapsa $\mathrm{spp}$ & Chlorococales $\mathrm{spp}$ & Asterionella $\mathrm{sp}$ & Chlamydomonas $\mathrm{spp}$ \\
Aphanocapsa roseana & Chodatella $\mathrm{spp}$ & Aulacoseira $\mathrm{spp}$ & Croomonaspp \\
Chroococales $\mathrm{spp}$ & Closteriopsis $\mathrm{spp}$ & A. distans & Cryptomonas $\mathrm{spp}$ \\
Cylindrospermopsis & C. acicularis & A. granulata & C. erosa \\
raciborskii & & & \\
Lyngbya $\mathrm{spp}$ & Closterium $\mathrm{spp}$ & Cyclotella $\mathrm{spp}$ & C. curvata \\
Merismopedia $\mathrm{spp}$ & Coelastrum $\mathrm{spp}$ & Cymbella $\mathrm{spp}$ & Dinobryon $\mathrm{spp}$ \\
Microcystis $\mathrm{spp}$ & C. indicum & Gomphonema $\mathrm{spp}$ & D. sertularia \\
M. aeruginosa & C. microporum & Gyrosigma $\mathrm{spp}$ & Euglena $\mathrm{spp}$ \\
Oscillatoria $\mathrm{spp}$ & C. reticulatum & Hantzschia & Gymnodinium $\mathrm{spp}$
\end{tabular}




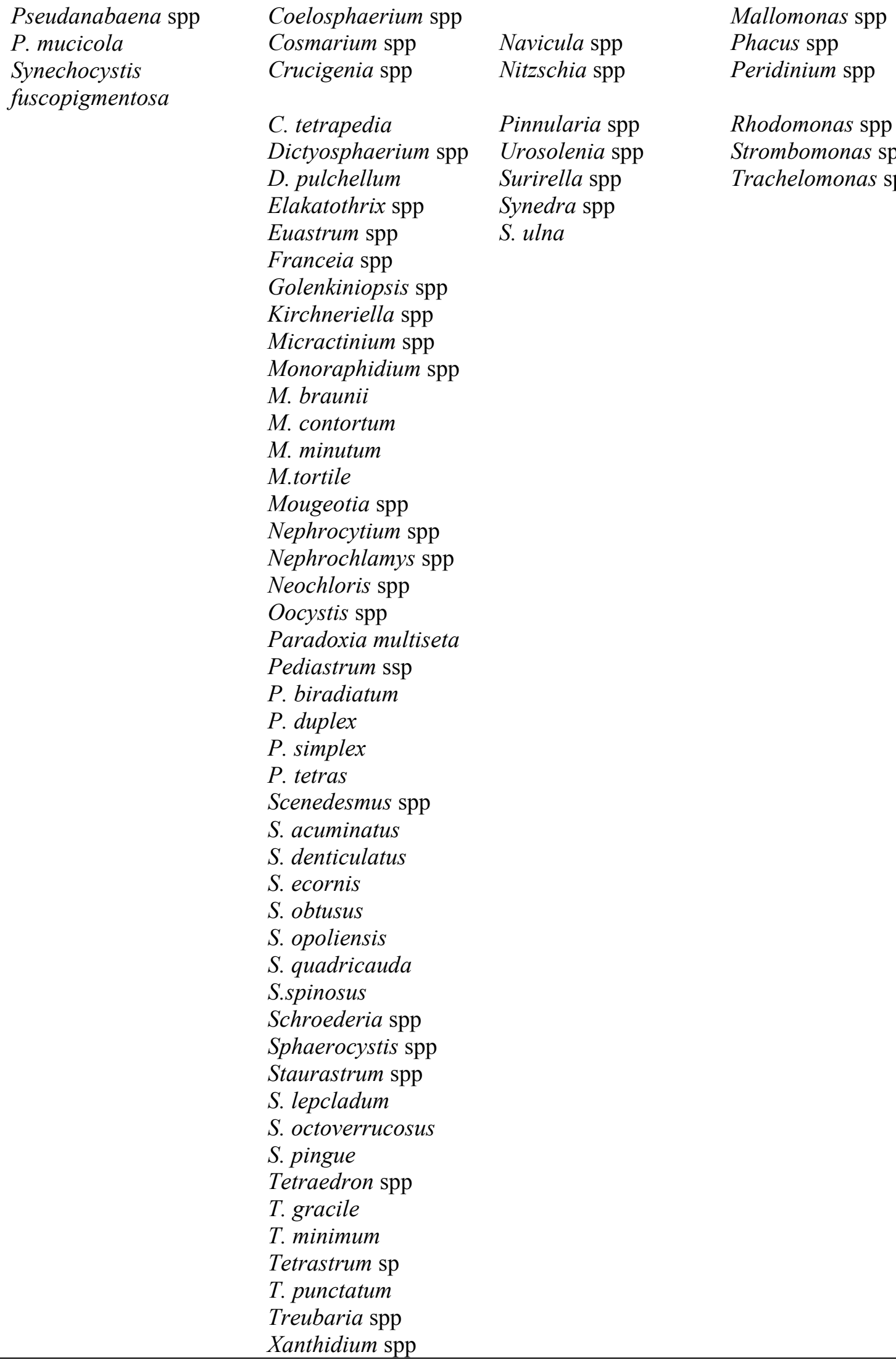


Na Figura 39 apresenta-se a abundância relativa do fitoplâncton no reservatório de Itaipu. As cianobactérias foram mais abundantes em todo o sistema, com média de $76 \%$. Na zona de transição a abundância relativa foi de $90 \%$ e na zona fluvial foi de $65 \%$.

As diatomáceas corresponderam ao segundo grupo mais abundante, com média de $14 \%$ para o reservatório de Itaipu. $\mathrm{Na}$ zona fluvial foi obtida a maior $(23 \%)$ e a menor contribuição na zona de transição $(7 \%)$.

As clorofíceas contibuiram, em média, com 5\%, sendo mais abundantes na zona fluvial $(9 \%)$ e menos abundantes na zona de transição $(2 \%)$. O mesmo padrão foi encontrado para os fitoflagelados, com freqüência média para todo reservatório de $5 \%$, com maior abundância registrada na zona lacustre (7\%) e a menor na zona de transição $(2 \%)$.

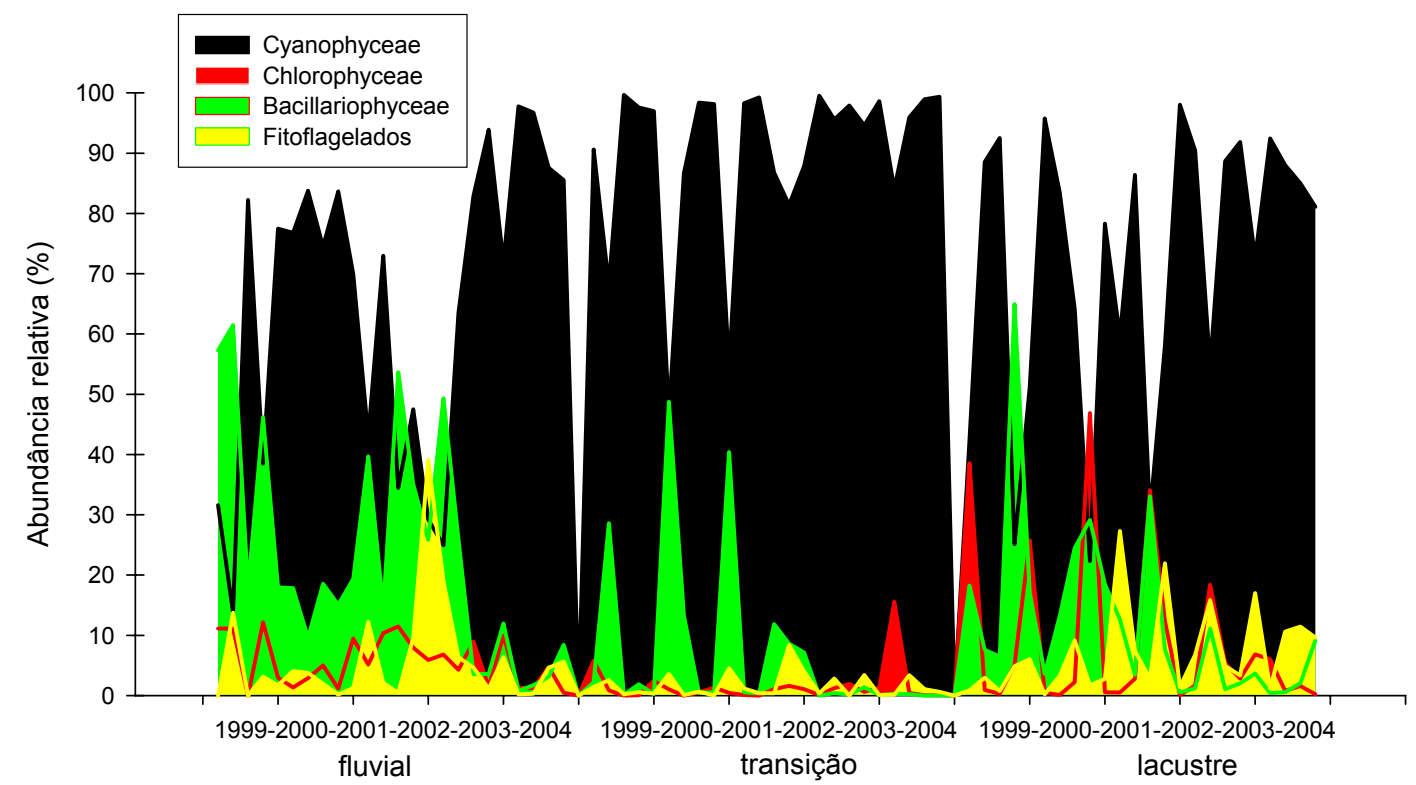

Figura 39: Variação da abundância relativa do fitoplâncton de acordo com as zonas do reservatório de Itaipu, para o período de 1999 a 2004.

\subsection{Composição, densidade e abundância relativa do zooplâncton}

$\mathrm{Na}$ Tabela 10 encontram-se discriminadas as espécies de zooplâncton identificadas no reservatório de Itaipu durante o período de 1999 a 2004.

Na Figura 40 estão apresentados os valores de densidades do zooplâncton, verificando-se que a abundância média do macrozooplâncton (Copepoda) foi de 48153org./mL para todo reservatório, com maior valor em março de 2002 
(188400org./mL), na zona de transição. A zona fluvial apresentou as menores concentrações, com média de 28747org./mL e mínima de 316org./mL nos meses de agosto e novembro de 2004. Na zona lacustre a densidade média foi de $52091 \mathrm{org} . / \mathrm{mL}$, com maior valor em novembro de 2000 (112073org./mL).

Os rotíferos corresponderam ao segundo grupo mais abundante em todo o reservatório (30493org./mL), tendo sido observada na zona de transição as maiores densidades (41589 org./mL), com valor máximo (155967org./mL) em novembro de 2003. A zona lacustre foi a que apresentou maior densidade em todo reservatório (184120org./mL em março de 2000 ), com valor médio de 32802org./mL.

A maior densidade dos cladocéros ocorreu na zona de transição (41589org./ml), onde também foi registrado o maior valor (155967org./ml) em novembro de 2002. Na zona fluvial registrou-se a menor abundância numérica entre as zonas do reservatório (23240org./ml), com a maior densidade (95606 org./ml) em novembro de 2001. A zona lacustre apresentou densidade média de 32802org./ml, sendo que a menor abundância numérica (223org./ml), em todo o reservatório, ocorreu nesta região.

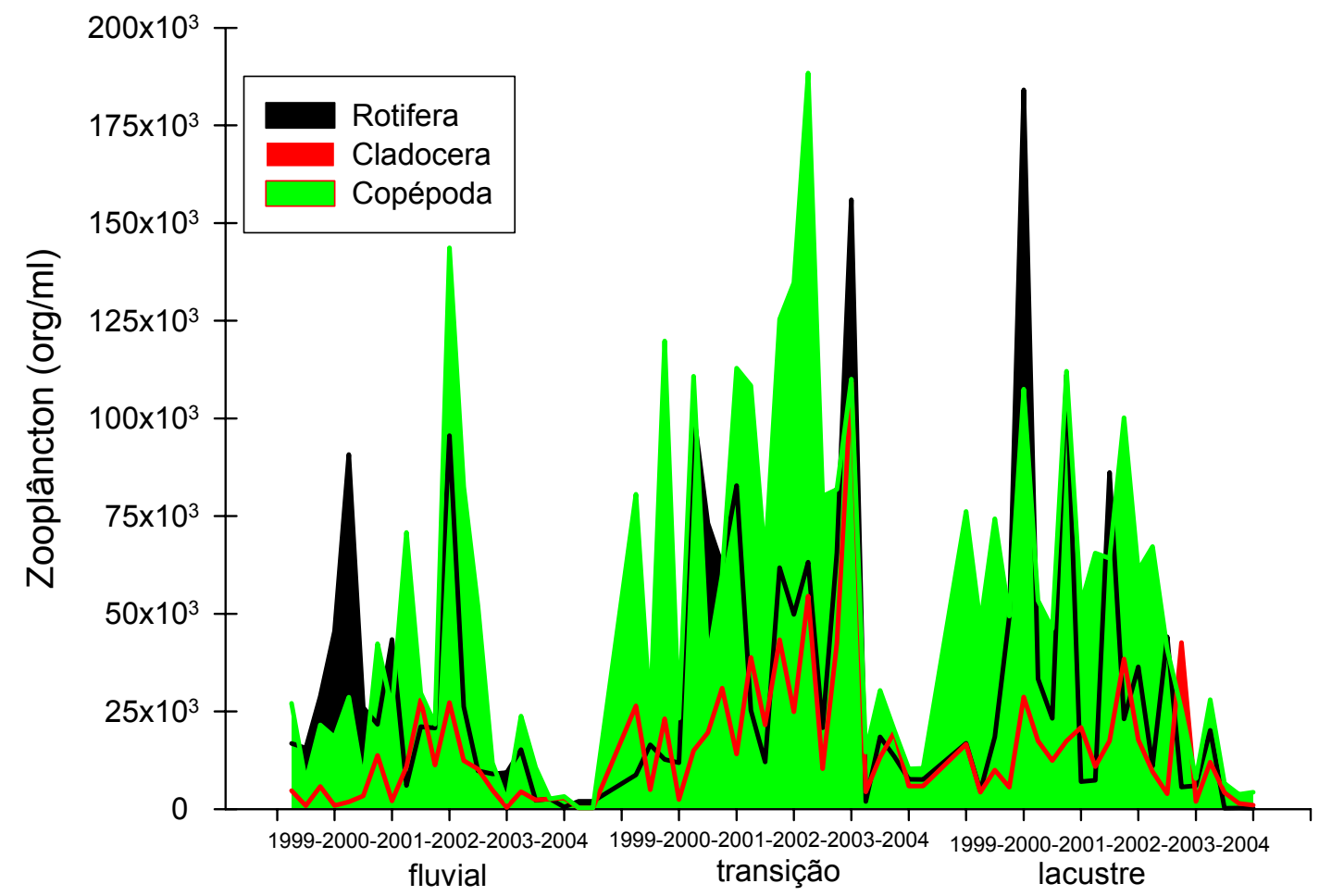

Figura 40: Variação da abundância numérica do zooplâncton de acordo com as zonas do reservatório de Itaipu, para o período de 1999 a 2004. 
Tabela 10: Composição do zooplâncton no reservatório de Itaipu, no período de 1999 a 2004.

\begin{tabular}{|c|c|c|c|}
\hline Copepoda & Cladocera & \multicolumn{2}{|c|}{ Rotifera } \\
\hline CYCLOPIDAE & SIDIDADE & BRACHIONIDAE & NOTOMMATIDAE \\
\hline Eucyclops spp. & Diaphanosoma spp. & Anuraeopsis sp. & Cephalodella spp. \\
\hline Thermocyclops spp. & D. birgei & Brachionus spp. & C. gibba \\
\hline T. decipiens & D. brevireme & B. angularis & TRICHOCERCIDAE \\
\hline T. minutus & D. fluviatile & B. calyciflorus & Trichocerca spp. \\
\hline Mesocyclops spp. & D. spinolosum & B. caudatus & T. capucina \\
\hline M. brasilianus & D. polyspina & $\begin{array}{l}\text { B. caudatus var. } \\
\text { personatus }\end{array}$ & T. chattoni \\
\hline M. longisetus & DAPHNIDAE & B. dolabratus & T. similis \\
\hline M. meridianus & Ceriodaphnia cornuta & B. falcatus & GASTROPODIDAE \\
\hline Metacyclops spp. & C. lacustris & B. mirus & Ascomorphasp \\
\hline M. mendocinus & C. silvestris & B. patulus & SYNCHAETIDAE \\
\hline Microcyclops sp. & Dapnhia gessneri & $\begin{array}{l}\text { B. patulus } \\
\text { macracanthus }\end{array}$ & Ploesoma spp. \\
\hline Paracyclops sp. & & B. macracanthus & Polyarthra spp. \\
\hline P. fimbriatus & $\begin{array}{l}\text { Simocephalus } \\
\text { serrulatus }\end{array}$ & B. quadridentatus & Synchaeta spp. \\
\hline Tropocyclops spp. & MOINIDADE & $\begin{array}{l}\text { Kellicotia } \\
\text { bostoniensis }\end{array}$ & ASPLANCHNIDAE \\
\hline DIAPTOMIDAE & Moina minuta & Keratella spp. & Asplanchna spp. \\
\hline $\begin{array}{l}\text { Argyrodiaptomus } \\
\text { spp. }\end{array}$ & BOSMINIDAE & Keratella americana & TESTUDINELLIDAE \\
\hline A. azevedoi & Bosmina $\mathrm{sp}$ & K.cochlearis & Testudinella patina \\
\hline A. furcatus & Bosmina hagmanni & K. lenzi & Horäella thomasoni \\
\hline Notodiaptomus spp. & B. huaronensis & K. tecta & PROALIDAE \\
\hline N. cf amazonicus & B. tubicen & K. tropica & Lacinularia spp. \\
\hline N. iheringi & Bosminopsis deitersi & Platyas leloupi & Ptygura spp. \\
\hline N. isabelae & MACROTHRICIDAE & P. quadricornis & Sinantherina spp. \\
\hline N. spinuliferus & Macrothrix spp. & EUCHLANIDAE & S. spinosa \\
\hline N. transitans & ILYOCRYPTIDAE & Euchlanis sp. & CONOCHILIDAE \\
\hline & Ilyocryptus spp. & E. dilatata & Conochilus spp. \\
\hline & CHYDORIDAE & MYTILINIDAE & C. dossuarius \\
\hline & Chydorus spp. & Mytilina sp. & C. unicornis \\
\hline & Leydigia $\mathrm{sp}$. & M. mucronata & HEXARTHRIDAE \\
\hline & & FLOSCULARIIDAE & Hexarthra spp. \\
\hline & & Pompholix spp. & H. intermedia \\
\hline & & TRICHOTRIDAE & $\begin{array}{l}\text { H. intermedia } \\
\text { braziliensis }\end{array}$ \\
\hline & & $\begin{array}{l}\text { Macrochaetus } \\
\text { sericus }\end{array}$ & H. propingua \\
\hline & & Trichotria sp. & FILINIDAE \\
\hline & & COLLURELIDAE & Filinia sp. \\
\hline & & Lepadella spp. & F. longiseta \\
\hline & & LECANIDAE & F. opoliensis \\
\hline & & Lecane spp & COLLOTHECIDAE \\
\hline & & L. bulla & Collotheca spp. \\
\hline & & Lecane curvicornis & Bdelloidea \\
\hline & & L. ludwigi & \\
\hline & & L. (M) monostyla & \\
\hline & & L. proiecta & \\
\hline
\end{tabular}


A abundância relativa dos grupos zooplanctônicos pode ser observada na Figura 41. Os copépodos foram mais abundantes em todo o reservatório, sendo que na zona lacustre obteve-se o maior valor médio (57,97\%). Na zona de transição a média foi de $53,71 \%$ e na zona fluvial foi de $42,32 \%$.

Os rotíferos corresponderam ao segundo grupo mais abundante, com média de $32,27 \%$ para todo o reservatório. Na zona fluvial foi obtida a maior média $(43,62 \%)$, na zona de transição obteve-se $27,87 \%$ e na zona foi verificada a menor abundância relativa $(24,76 \%)$.

Os cladóceros apresentaram a menor abundância relativa em todo reservatório, com média de 16,53\%. A maior abundância ocorreu na zona de transição (18,4\%), semelhante à zona lacustre $(17,26 \%)$, sendo que a menor contribuição ocorreu na zona fluvial $(14,04 \%)$.

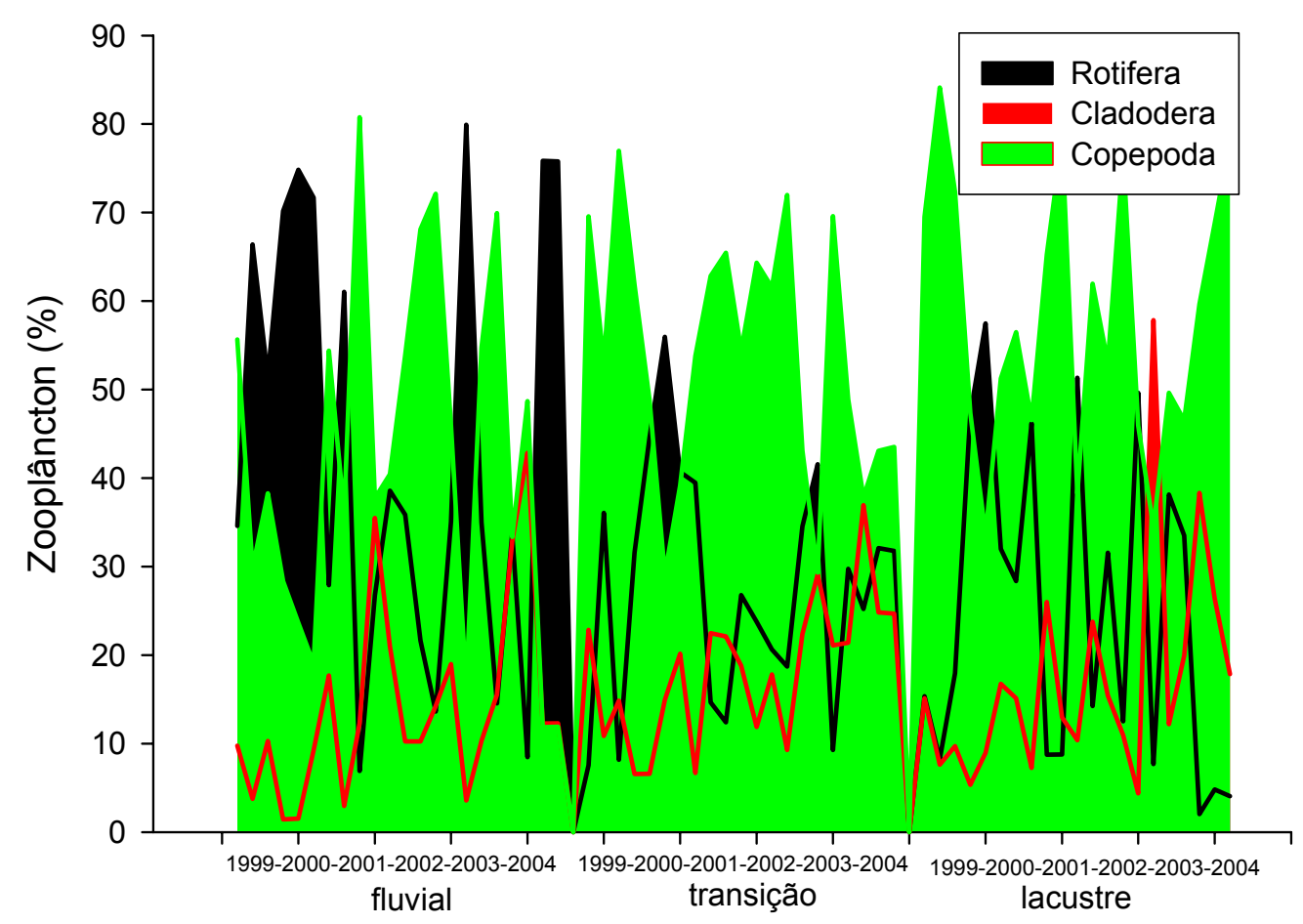

Figura 41: Variação da abundância relativa do zooplâncton de acordo com as zonas do reservatório de Itaipu, para o período de 1999 a 2004. 


\subsection{Peixes}

\subsubsection{Caracterização das guildas tróficas de peixes}

$\mathrm{Na}$ Tabela 11 estão apresentadas as principais espécies de peixes presentes no reservatório de Itaipu, distribuídas de acordo com a guilda trófica a que pertencem.

Tabela 11: Principais espécies de peixes, nomes científicos e guildas tróficas no reservatório de Itaipu, para o período de 2000 a 2004.

\begin{tabular}{|c|c|c|}
\hline Nome vulgar & Nome científico & Guilda trófica \\
\hline bagre & Rhamdia quelen (Quoy \& Gaimard, 1824) & piscívoro \\
\hline bagre africano & Clarias gariepinus (Burchell, 1822) & piscívoro \\
\hline bagre sapo & Pseudopimelodus bufonius (Valenciennes, 1840) & piscívoro \\
\hline barbado & Pinirampus pirinampu (Spix, 1829) & piscívoro \\
\hline bocudo(manduvê) & Ageneiosus valenciennesi (Bleeker, 1894) & piscívoro \\
\hline curvina & Plagioscion squamosissimus (Heckel, 1840) & piscívoro \\
\hline dourado & Salminus maxillosus (Valenciennes, 1849) & piscívoro \\
\hline dourado cachorro & Acestrorhynchus lacustris (Reinhardt, 1874) & piscívoro \\
\hline jurupoca & Hemisorubim platyrhynchos (Valenciennes, 1840 ) & piscívoro \\
\hline jaú & Paulicea luetkeni (Steindachner, 1875) & piscívoro \\
\hline jejum & Hoplerythrinus unitaeniatus (Spix, 1829) & piscívoro \\
\hline linguado & Catathyridium jenynsi (Gunther, 1862) & piscívoro \\
\hline mucum & Synbranchus marmoratus (Bloch, 1795) & piscívoro \\
\hline peixe cachorro & Acestrorhynchus lacustris (Reinhardt, 1874) & piscívoro \\
\hline peixe cadela & Galeocharax knerii (Steindachner, 1879) & piscívoro \\
\hline pintado & Pseudoplatystoma corruscans (Agassiz, 1829) & piscívoro \\
\hline piranha & Serrasalmus marginatus (Valenciennes, 1847) & piscívoro \\
\hline raia & Potamotrygon motoro (Muller \& Henle, 1841) & piscívoro \\
\hline traira & Hoplias malabaricus (Bloch, 1794) & piscívoro \\
\hline tucunare & Cichla monoculus (Spix, 1831) & piscívoro \\
\hline apaiari & Astronotus ocellatus (Agassiz, 1831) & onívoro \\
\hline armado & Pterodoras granulosus (Valenciennes, 1821) & onívoro \\
\hline mandi & Pimelodus maculatus (Lacépède, 1803) & onívoro \\
\hline morrudo & Parauchenipterus galeatus (Linnaeus, 1766) & onívoro \\
\hline pacu & Piaractus mesopotamicus (Holmberg, 1887) & onívoro \\
\hline pacu prata & Myloplus cf. tiete (Eigenmann \& Norris, 1900) & onívoro \\
\hline piau & Leporinus friderici (Bloch, 1794) & onívoro \\
\hline itui cavalo & Apteronotus albifrons (Linnaeus, 1766) & insetívoro \\
\hline joaninha & Crenicichla $\mathrm{sp}$ & insetívoro \\
\hline luz baixa & Auchenipterus osteomystax (Ribeiro 1918). & insetívoro \\
\hline morenita & Gymnotus carapo (Linnaeus, 1758) & insetívoro \\
\hline peixe espada & Rhamphichthys hahni (Meiken, 1937) & insetívoro \\
\hline piapara & Leporinus elongatus (Valenciennes, 1849) & insetívoro \\
\hline piracanjuba & Brycon orbignyanus (Valenciennes, 1849 ) & insetívoro \\
\hline piava & Schizodon altoparanae (Garavello \& Britski, 1990) & herbívoro \\
\hline piavucu & Schizodon borelli (Boulenger, 1900) & herbívoro \\
\hline
\end{tabular}




\begin{tabular}{|c|c|c|}
\hline tilapia & Tilapia rendalli (Boulenger, 1896) & herbívoro \\
\hline caboja & Hoplosternum littorale (Hancock, 1828) & bentófago \\
\hline armadinho & Trachydoras paraguayensis (Eigenmann \& Ward, 1907) & bentófago \\
\hline cara & Satanoperca pappaterra $($ Heckel, 1840) & bentófago \\
\hline carpa & Cyprinus carpio (Linnaeus, 1758) & detritívoro \\
\hline cascudo & Hypostomus sp & detritívoro \\
\hline chinelo & Loricaria $\mathrm{sp}$ & detritívoro \\
\hline curimba & Prochilodus lineatus (Valenciennes, 1836) & iliófago \\
\hline mapará & Hypophthalmus edentatus (Spix, 1829) & zooplanctófago \\
\hline
\end{tabular}

\subsubsection{Distribuição das guildas tróficas de peixes}

Na Figura 42 estão representadas as guildas tróficas das espécies de peixes e sua distribuição entre as zonas do reservatório. Os onívoros representaram o grupo com maior peso médio para todo reservatório, com $129253 \mathrm{~kg}$. Os piscívoros tiveram um peso médio de $81637 \mathrm{~kg}$, os insetívoros de $1199 \mathrm{~kg}$, os herbívoros de $855 \mathrm{~kg}$, os bentófagos com $3152 \mathrm{~kg}$, os detritívoros com $19045 \mathrm{~kg}$, os iliófagos com $14535 \mathrm{~kg}$ e os zooplanctófagos com $22735 \mathrm{~kg}$.

$\mathrm{Na}$ zona fluvial foram obtidas os maiores pesos de onívoros (209028kg), com maior valor $(269533 \mathrm{~kg}$ ) em 2001 e peso mínimo de $155554 \mathrm{~kg}$ em 2004 . Os detritívoros apresentaram o segundo maior peso $(47365 \mathrm{~kg})$, com maior valor em 2001 (87577kg) e menor valor em $2004(20867 \mathrm{~kg})$, seguida pelos piscívoros $(24239 \mathrm{~kg})$, insetívoros $(2302$ $\mathrm{kg})$, iliófagos $(8630 \mathrm{~kg})$, zooplanctófagos $(1740 \mathrm{~kg})$, herbívoros $(294 \mathrm{~kg})$ e bentófagos $(111 \mathrm{~kg})$.

$\mathrm{Na}$ zona de transição os onívoros também apresentaram os maiores pesos médios (83048kg). Os piscívoros apresentaram peso de $81575 \mathrm{~kg}$, seguido dos iliófagos (25494kg) e dos zooplanctófagos (23252kg). Os detritívoros (3064kg), bentófagos $(1408 \mathrm{~kg})$, herbívoros $(1356 \mathrm{~kg})$ e insetívoros $(249 \mathrm{~kg})$ apresentaram os menores pesos.

$\mathrm{Na}$ zona lacustre os piscívoros apresentaram o maior peso (139096kg), seguidos pelos onívoros $(95683 \mathrm{~kg})$, zooplânctófagos $(43214 \mathrm{~kg})$, detritívoros $(6707 \mathrm{~kg})$, iliófagos $(9481 \mathrm{~kg})$, bentófagos $(7937 \mathrm{~kg})$ e herbívoros $(913 \mathrm{~kg})$. O maior valor dos piscívoros (164236kg) ocorreu em 2001. 
Os maiores pesos registrados, de acordo com as guildas tróficas dos peixes encontrados no reservatório, estão apresentados na Tabela 12.

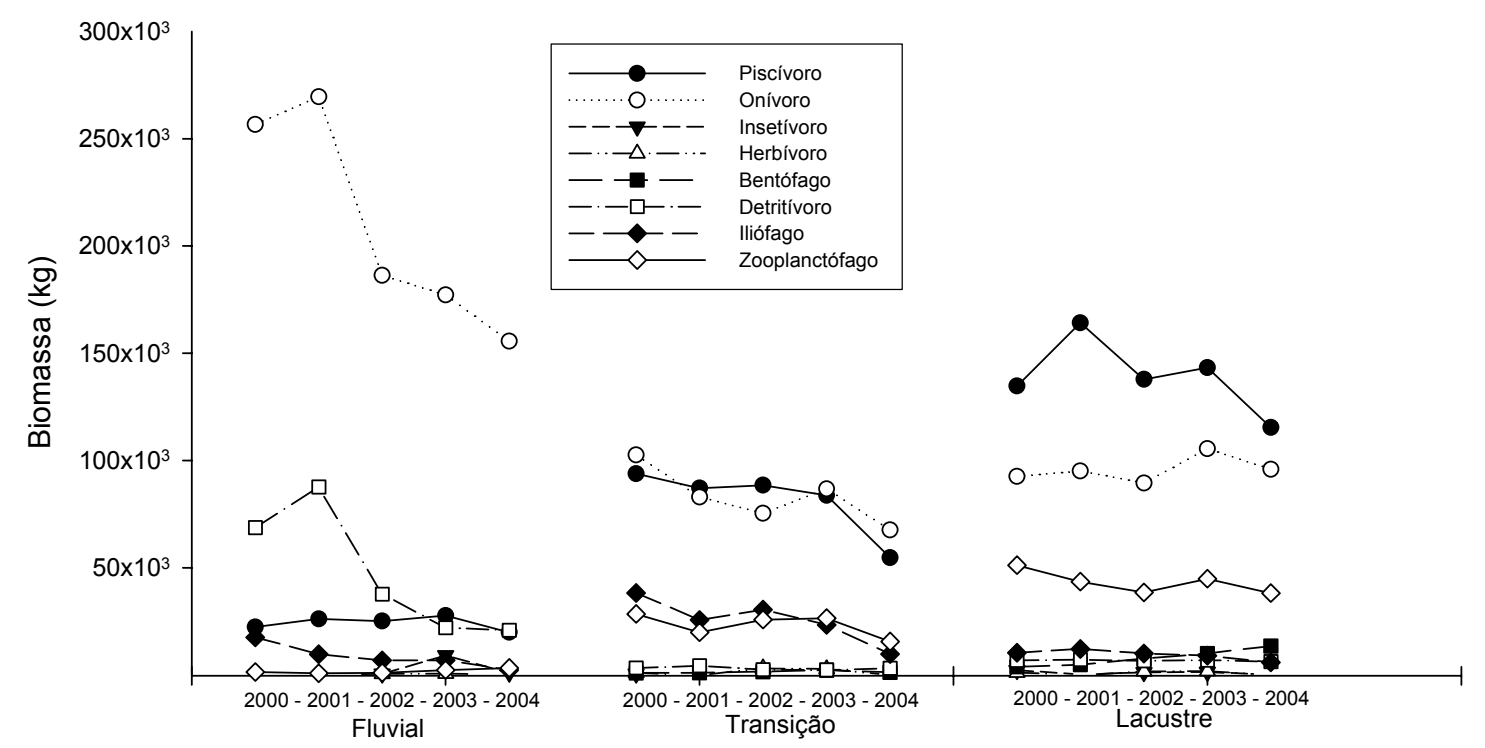

Figura 42: Variação dos pesos de peixes de acordo com as guildas tróficas e zonas do reservatório de Itaipu, para o período de 2000 a 2004.

Tabela 12: Distribuição dos pesos e abundância das guildas tróficas dos peixes para o reservatório de Itaipu.

\begin{tabular}{lccc}
\hline & Peso (ton) & Peso médio (ton) & Frequência (\%) \\
\hline piscívoro & $1.306,2$ & 81,6 & 30,5 \\
onívoro & $2.068,0$ & 129,2 & 47,2 \\
insetívoro & 19,2 & 1,2 & 0,5 \\
herbívoro & 13,7 & 0,9 & 0,3 \\
bentófago & 50,4 & 3,2 & 1,1 \\
detritívoro & 304,7 & 19,0 & 6,2 \\
iliófago & 232,6 & 14,5 & 5,7 \\
zooplanctófago & 363,8 & 22,7 & 8,5 \\
\hline
\end{tabular}

\subsubsection{Distribuição da abundância relativa das guildas tróficas de peixes}

Na Figura 43 está apresentada a abundância relativa dos grupos de peixes nas zonas fluvial, transição e lacustre do reservatório de Itaipu. Os onívoros foram o grupo mais abundante em todo o reservatório, com 47,2\%, seguido pelos piscívoros $(30,5 \%)$, zooplanctívoros $(8,5 \%)$, detritívoros $(6,2 \%)$, iliófagos $(5,7 \%)$, bentívoros $(1,1 \%)$, insetívoros $(0,5 \%)$ e herbívoros $(0,3 \%)$. 
$\mathrm{Na}$ zona lacustre os onívoros foram mais abundantes $(71,8 \%)$, seguidos pelos detritívoros $(14,9 \%)$ e piscívoros $(8,7 \%)$. Os demais grupos apresentaram reduzida abundância, não tendo sido registrada a presença de bentívoros nesta região.

A zona de transição também apresentou uma maior abundância relativa de onívoros $(38,3 \%)$, seguidos pelos piscívoros $(37,2 \%)$. Os iliófagos tiveram 11,2\% de abundância relativa, seguido dos zooplanctívoros $(10,6 \%)$, detritívoros $(1,4 \%)$, bentívoros $(0,7 \%)$, herbívoros $(0,6 \%)$ e insetívoros $(0,1 \%)$.

$\mathrm{Na}$ zona lacustre foi obtida a maior contribuição dos piscívoros $(45,6 \%)$, seguidos pelos onívoros $(31,5 \%)$, zooplanctívoros $(14,2 \%)$, iliófagos $(3,1 \%)$, bentívoros $(2,7 \%)$, detritívoros $(2,2 \%)$ e, por último, os herbívoros e insetívoros $(0,3 \%)$.

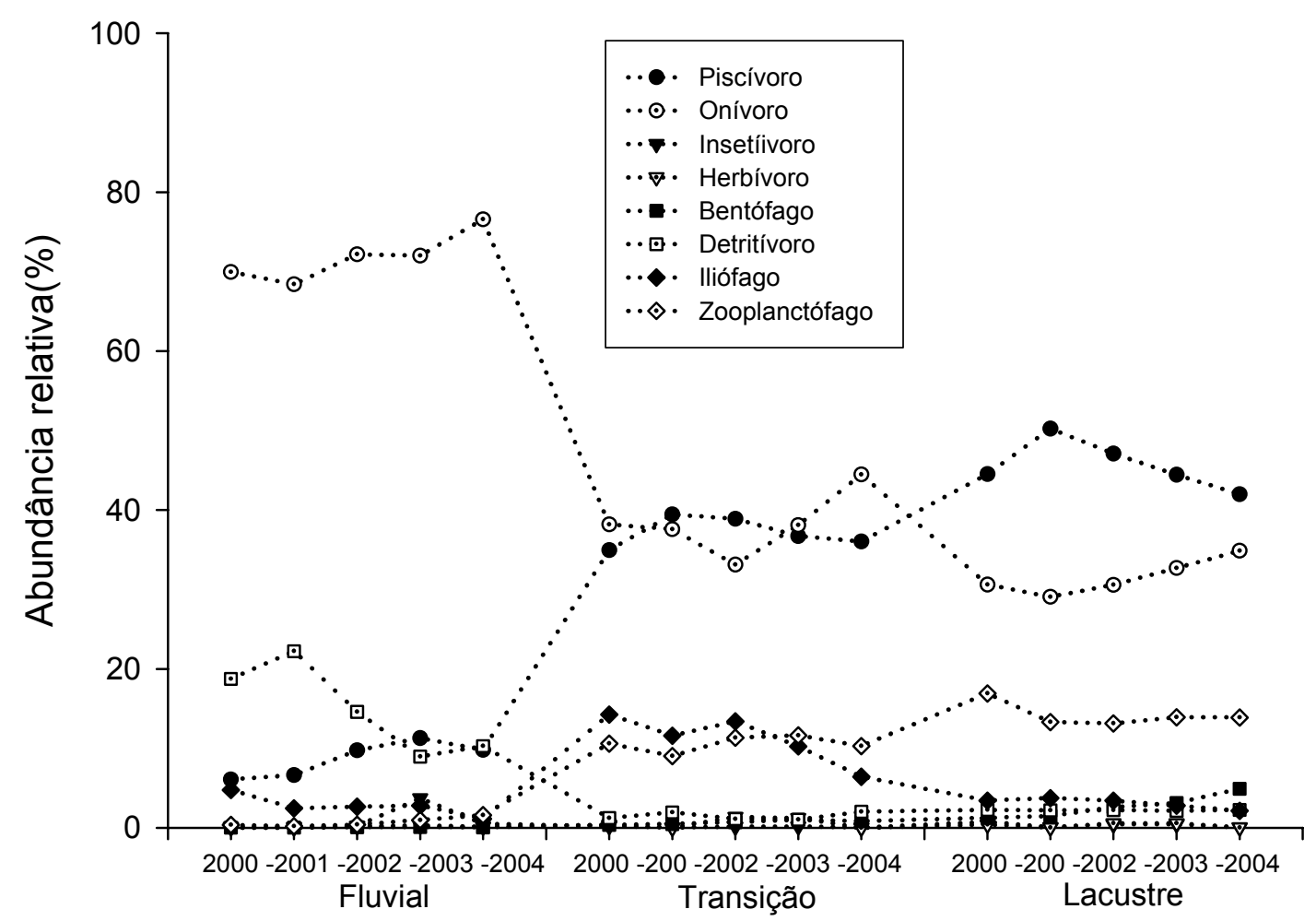

Figura 43: Variação da abundância relativa das guildas tróficas dos peixes de acordo com as zonas do reservatório de Itaipu, para o período de 2000 a 2004. 


\subsection{Análise das interações tróficas no reservatório de Itaipu: efeitos diretos}

\subsubsection{Peixes piscívoros versus demais peixes}

Para testar a hipótese de cascata trófica no reservatório, foram realizadas análises de correlação com os níveis tróficos verificados um a um, determinando assim as interações entre os mesmos.

Os piscívoros apresentaram relações significativas com quatro guildas tróficas de peixes (Figura 44):

- Negativas: onívoros e detritívoros

- Positivas: bentívoros e zooplanctívoros.

Esta análise mostra que o aumento da biomassa de piscívoros ocasiona um decréscimo nas biomassas de onívoros e detritívoros, e o aumento da biomassa dos piscívoros implica em um aumento nas biomassas de bentívoros e zooplanctívoros.

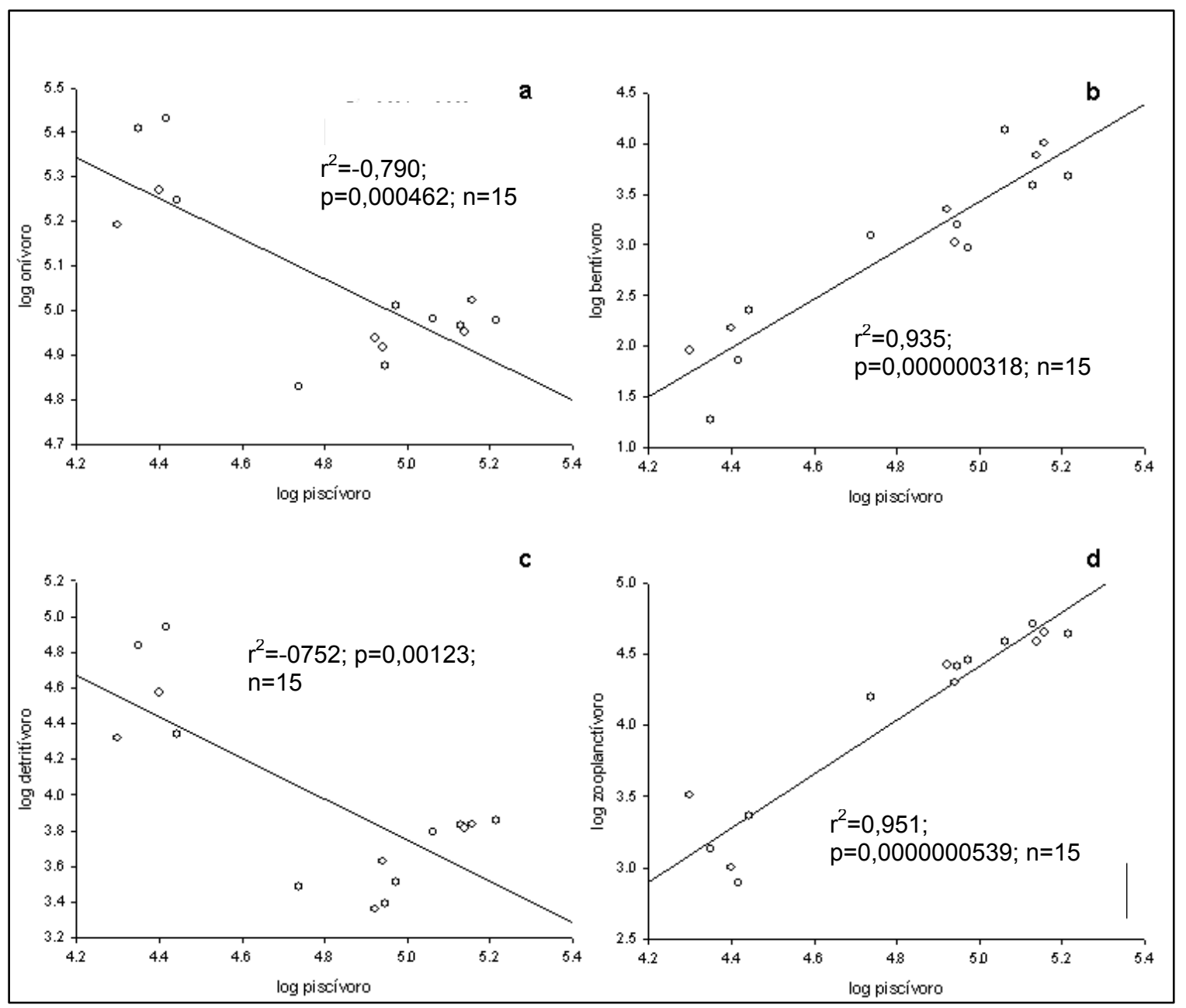

Figura 44: Correlação entre log de piscívoros e (a) onívoro, (b) bentívoro, (c) detritívoro e (d) zooplanctófago para o reservatório de Itaipu, para o período de 2000 a 2004. 


\subsubsection{Onívoros versus demais peixes}

Na Figura 45 são apresentadas as relações dos onívoros com os outros grupos de peixes que também tiveram relações significativas sobre três grupos de peixes. Para esta guilda, os efeitos negativos foram observados em relação aos bentívoros e zooplanctívoros, e os efeitos positivos apenas em relação aos detritívoros.

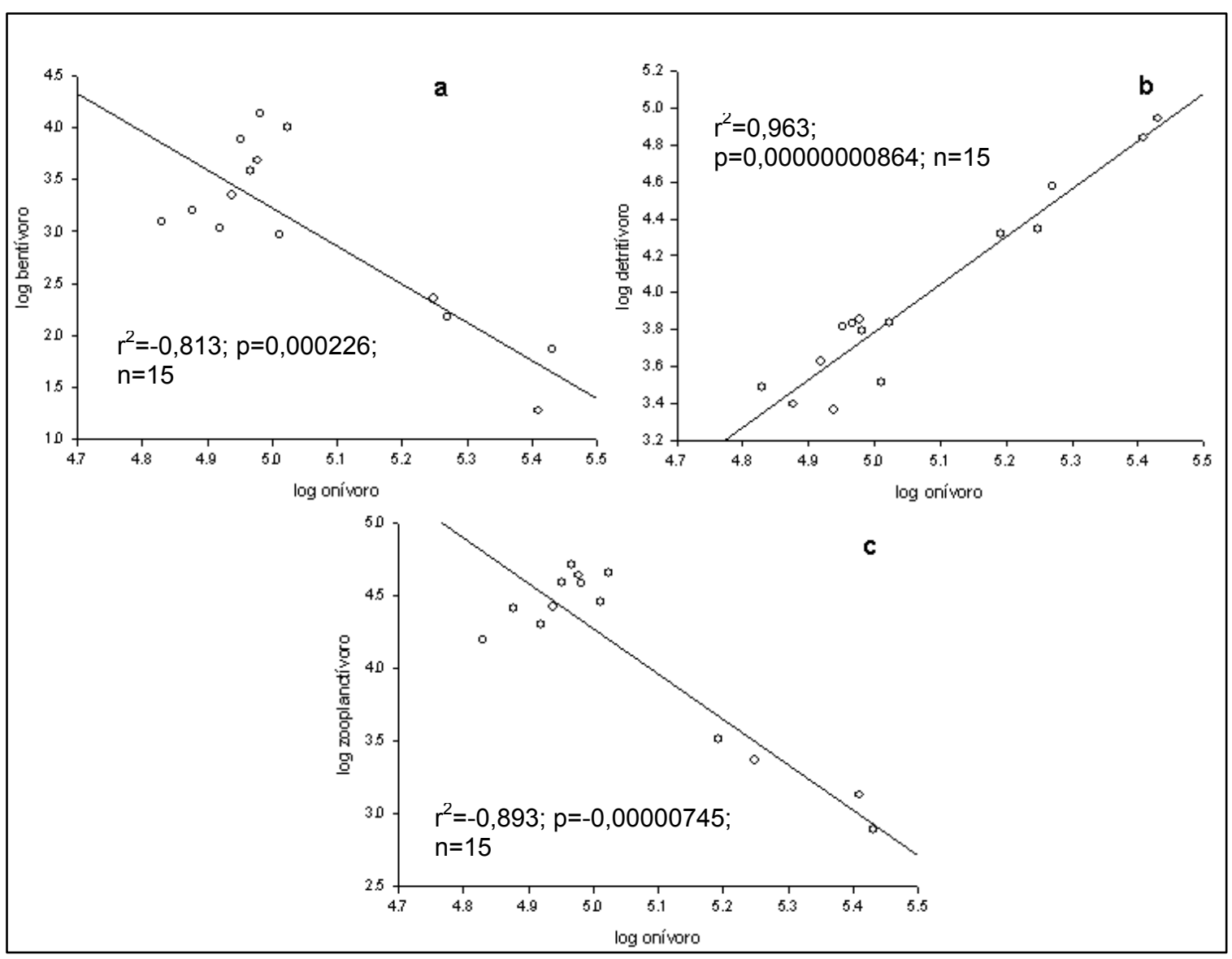

Figura 45: Correlação entre log de onívoros e (a) bentófago, (b) detritívoro e (c) zooplanctófago para o reservatório de Itaipu, para o período de 2000 a 2004.

\subsubsection{Peixe versus zooplâncton}

A Figura 46 mostra as relações entre os grupos de peixes e o macrozooplâncton no reservatório. $\mathrm{O}$ único grupo que apresentou relações significativas com $\mathrm{o}$ zooplâncton foi o dos iliófagos. Tanto os cladóceros como os copépodos apresentaram relações positivas. 


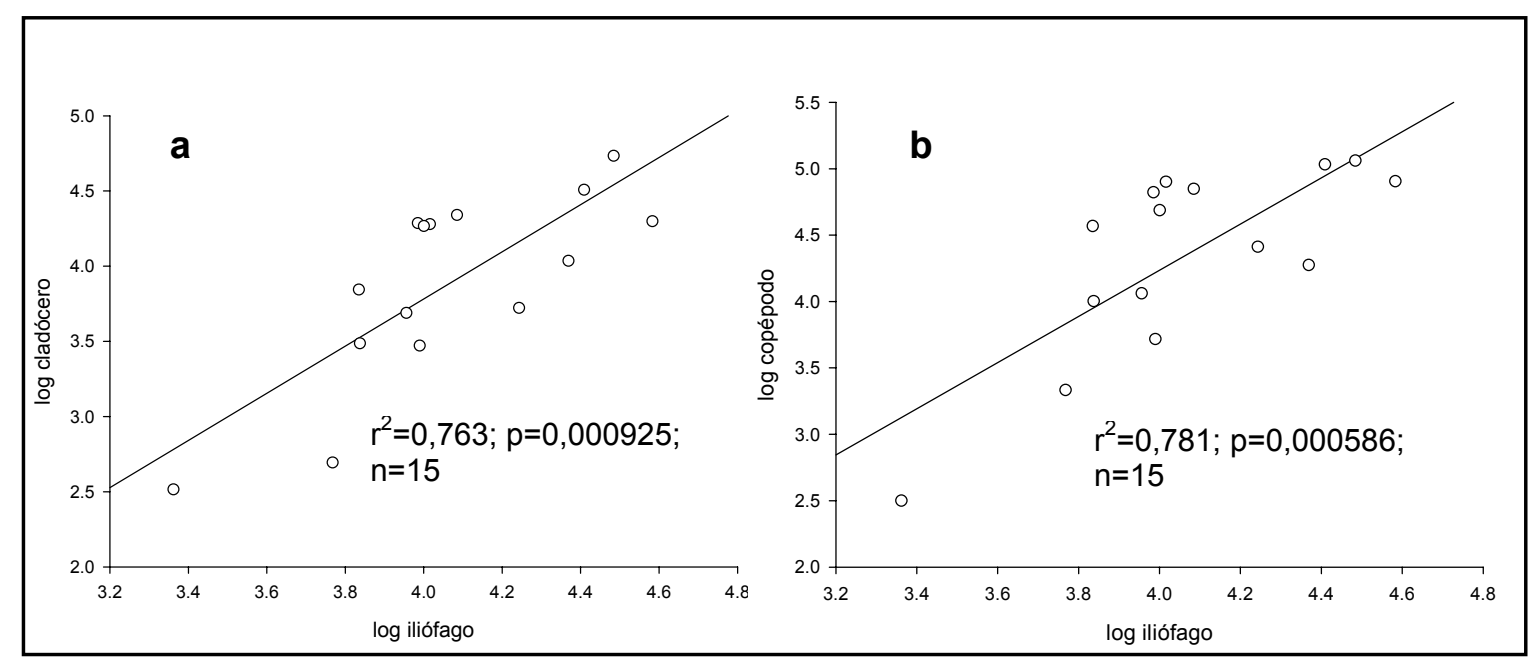

Figura 46: Correlação entre os log de iliófagos e (a) cladóceros e (b) copépodos, para o reservatório de Itaipu, para o período de 2000 a 2004.

\subsubsection{Macrozooplâncton versus clorofila}

Na Figura 47 são apresentados o resultado da relação entre macrozooplânton (Cladocera e Copepoda) e clorofila no reservatório. O resultado desta análise não foi significativo, mas observa-se uma forte tendência positiva nesta análise. $\mathrm{O}$ resultado indica que o aumento da biomassa do macrozooplâncton ocasiona um aumento das concentrações de clorofila no reservatório.

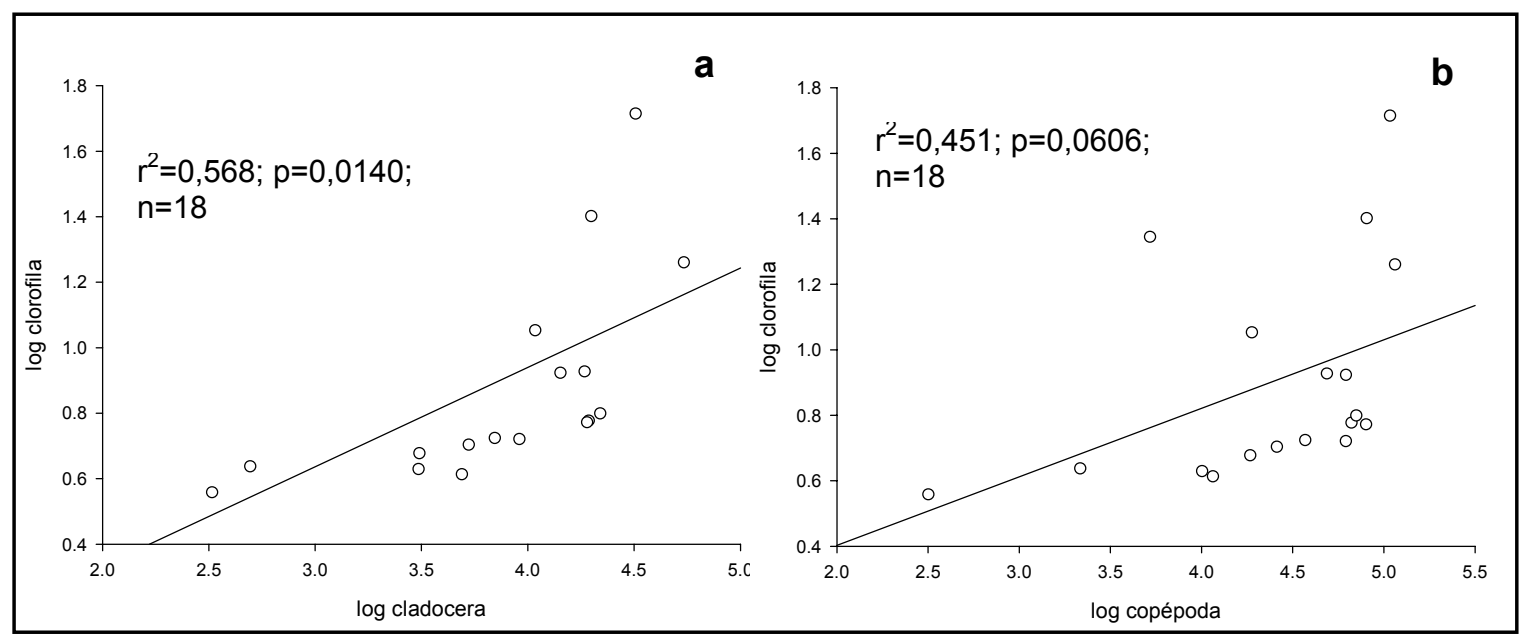

Figura 47: Correlação do entre (a) $\log$ de Cladocera e log clorofila e (b) log de Copepoda e clorofila, para o reservatório de Itaipu, no período de 2000 a 2004. 


\subsubsection{Clorofila versus fósforo total e TKN}

Na Figura 48 observa-se a correlação entre clorofila e fósforo total para todo o reservatório. A relação foi positiva e significativa e a análise mostra que o aumento da concentração do fósforo total implica no aumento da concentração de clorofila no reservatório. O mesmo acontecendo para a correlação entre a clorofila e TKN.

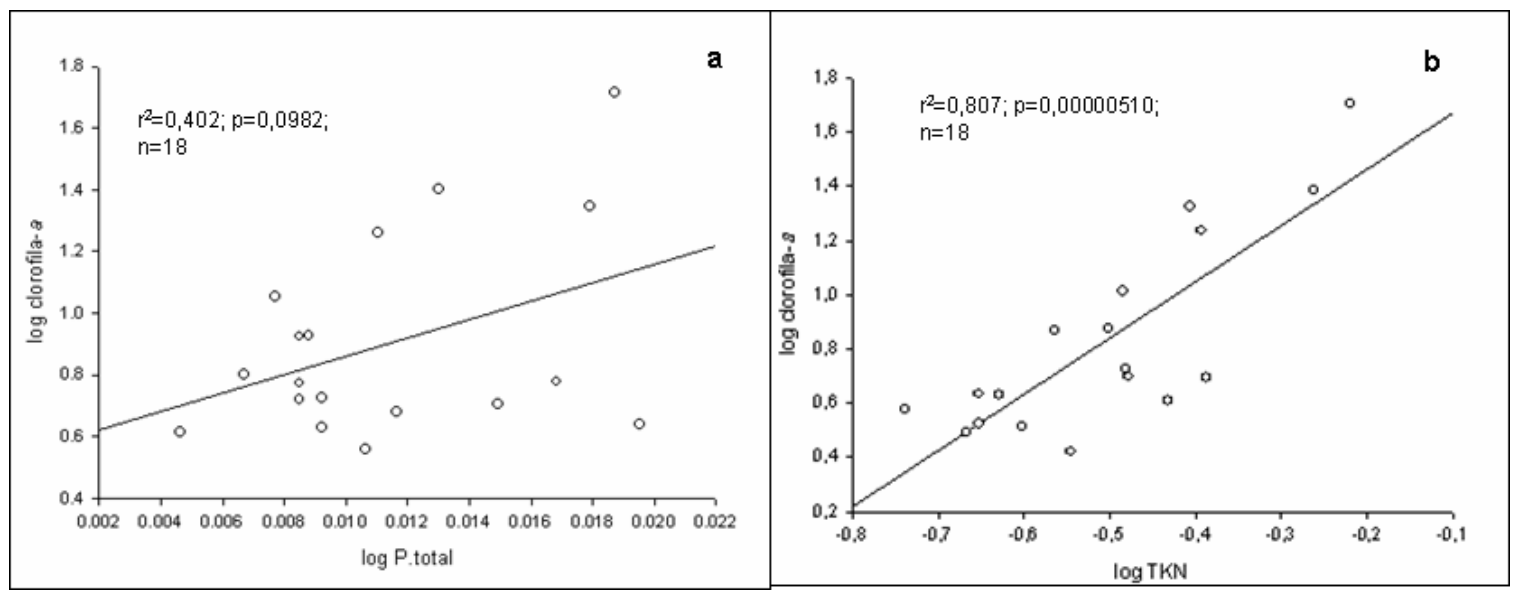

Figura 48: Correlação entre clorofila e fósforo total (a) e TKN (b) do reservatório de Itaipu, com os dados médios agrupados por zona.

\subsection{Análise das interações tróficas no reservatório de Itaipu: efeitos indiretos}

\subsubsection{Peixes versus clorofila}

Na Figura 49 são apresentadas as relações indiretas entre as guildas tróficas de peixes e clorofila em todo o reservatório. Os grupos de peixes que tiveram relação com a clorofila foram os onívoros (relação negativa), os insetívoros (relação negativa), os detritívoros (relação negativa) e os iliófagos (relação positiva). Esta análise mostra que o aumento da biomassa de onívoros, insetívoros e detritívoros favorecem uma redução na concentração de clorofila, ao contrário do que aconteceu com os zooplanctívoros, quando o aumento de sua biomassa ocasionou um aumento da clorofila no reservatório. 


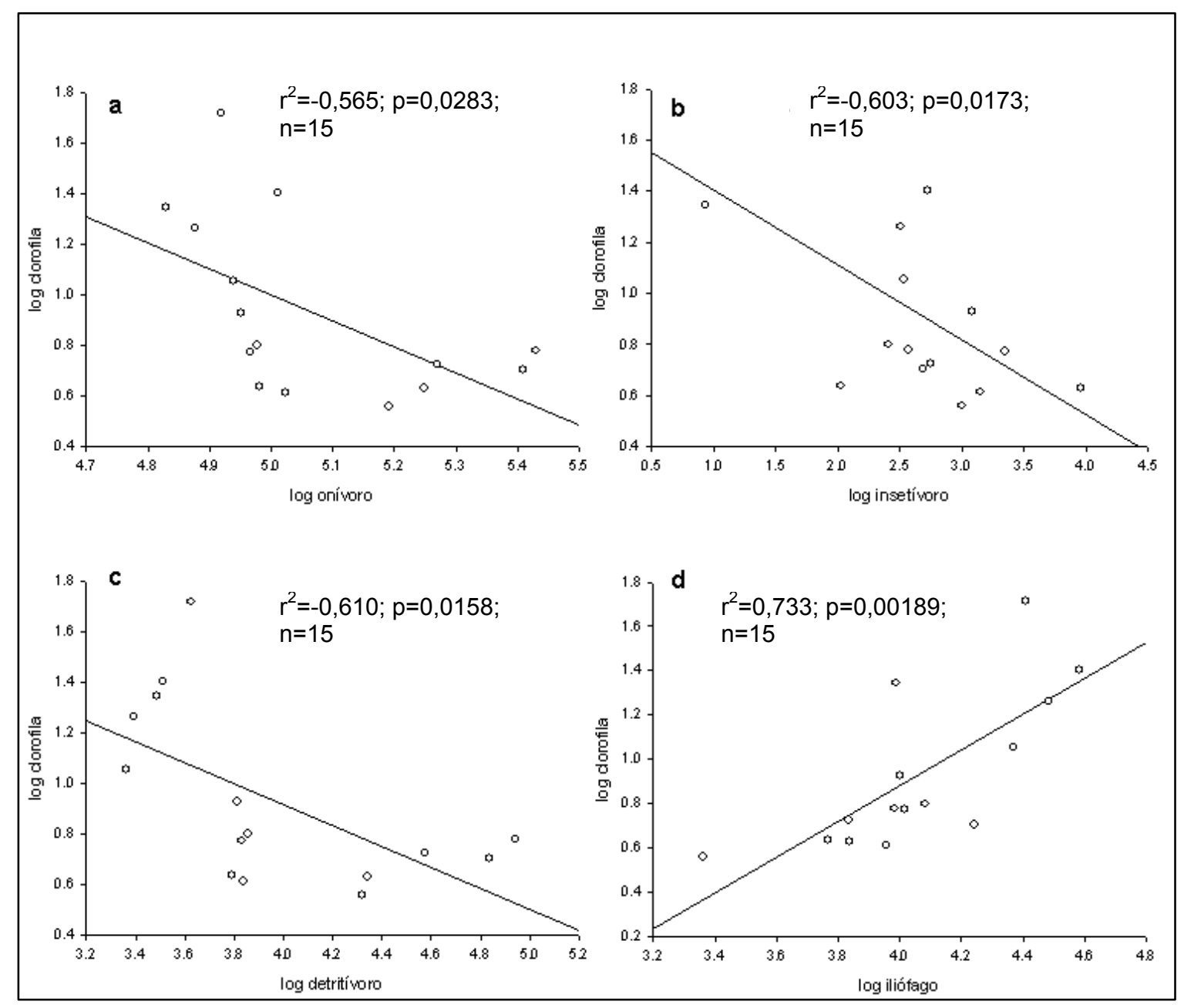

Figura 49: correlação entre (a) $\log$ de onívoro e log de clorofila, (b) $\log$ de insetívoro e log de clorofila, (c) log de detritívoro e log de clorofila e (d) log de iliófago e log de clorofila, para o reservatório de Itaipu, para o período de 2000 a 2004.

\subsubsection{Peixe versus fósforo total}

$\mathrm{Na}$ Figura 50 são apresentados os resultados das interações indiretas entre os grupos de peixes e as concentrações de fósforo total no reservatório. Os grupos de peixes que apresentaram relações negativas foram os insetívoros e os herbívoros. Esta análise mostra que o aumento da biomassa de insetívoros e herbívoros contribui para o decréscimo nas concentrações de fósforo total do reservatório. 


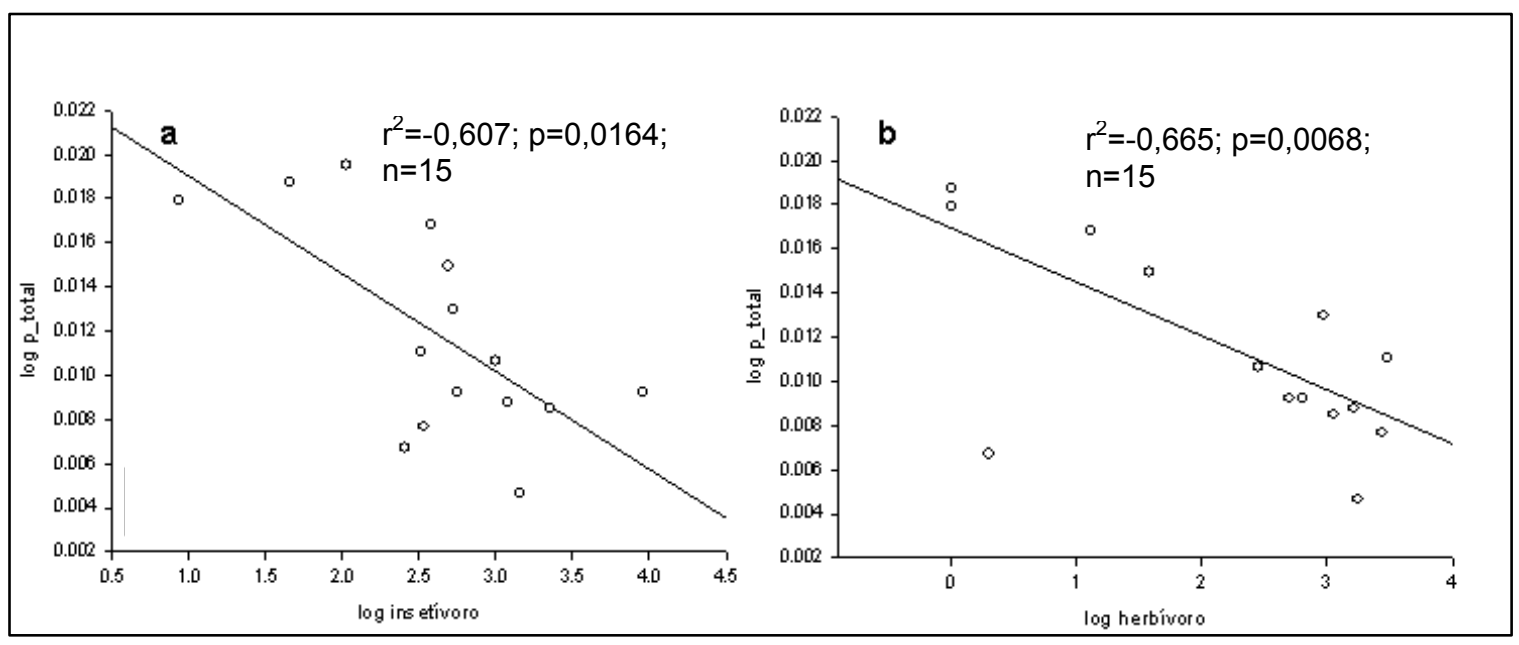

Figura 50: Correlação entre (a) $\log$ de insetívoro e $\log \mathrm{P}$ total e (b) $\log$ de herbívoro e $\log$ de P.total, para o reservatório de Itaipu, no período de 2000 a 2004.

\subsubsection{Peixes versus cianobactérias}

A Figura 51 mostra os resultados das interações indiretas entre os grupos de peixes e as cianobactérias. Os onívoros, os detritívoros e insetívoros apresentaram relações negativas e os zooplanctívoros apresentaram relação positiva.

Esta análise mostra que o aumento do log da biomassa dos onívoros, insetívoros e detritívoros exercem um decaimento no $\log$ das concentrações de cianobactérias. No caso dos zooplanctívoros, ocorre o inverso: o aumento de sua biomassa acarretou um aumento na densidade de cianobactérias.

\subsubsection{Clorofila versus cianobactéria}

A Figura 52 mostra a relação positiva entre clorofila e cianobactérias, indicando que o aumento do da concentração da clorofila apresentou relação com o aumento do da densidade das cianobactérias. 


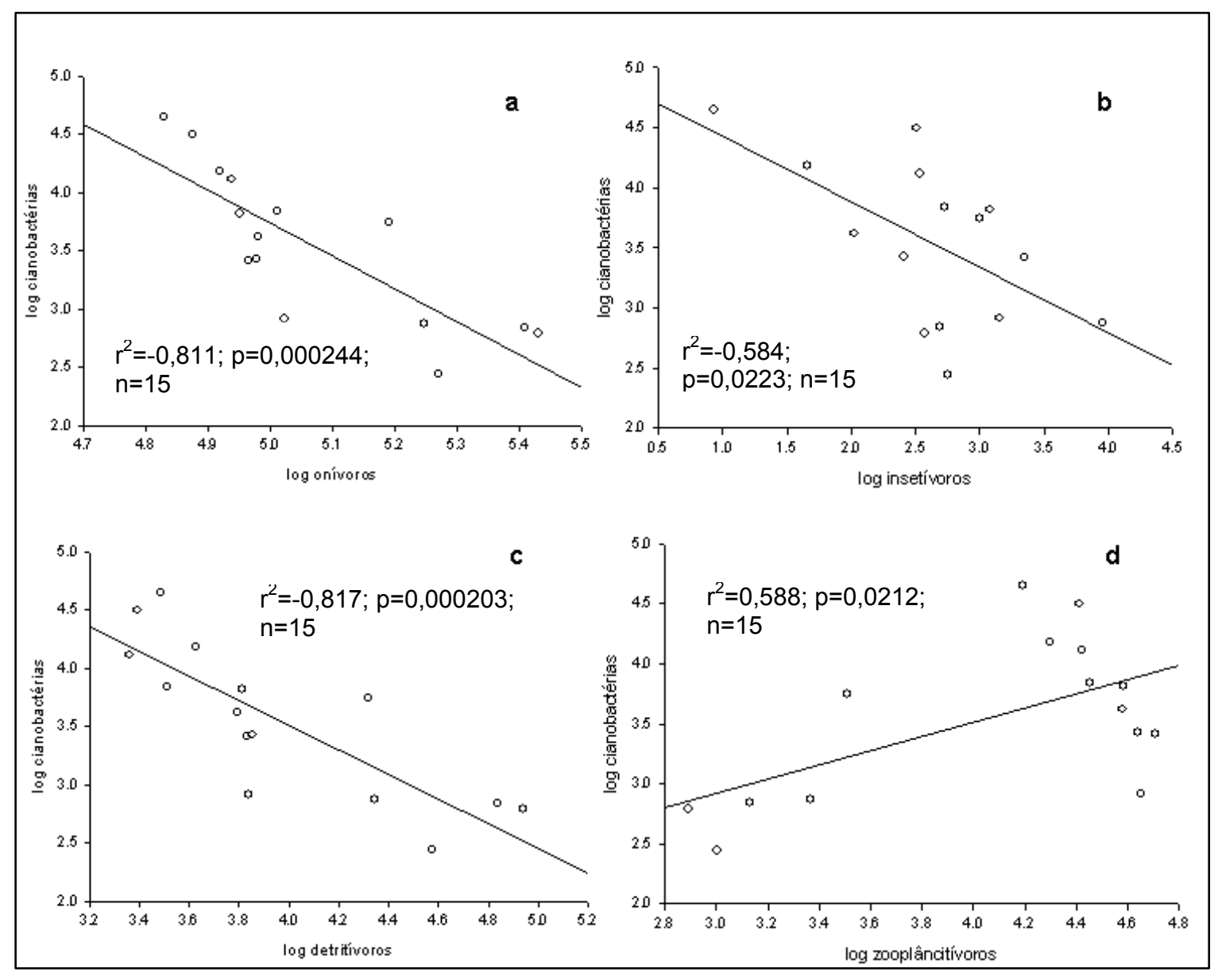

Figura 51: Correlação entre (a) log de onívoros e log de cianobactérias, (b) log de insetívoros e $\log$ de cianobactérias, (c) log de detritívoros e log de cianobactérias e (d) log de zooplanctófagos e log de cianobactérias, para o reservatório de Itaipu, no período de 2000 e 2004.

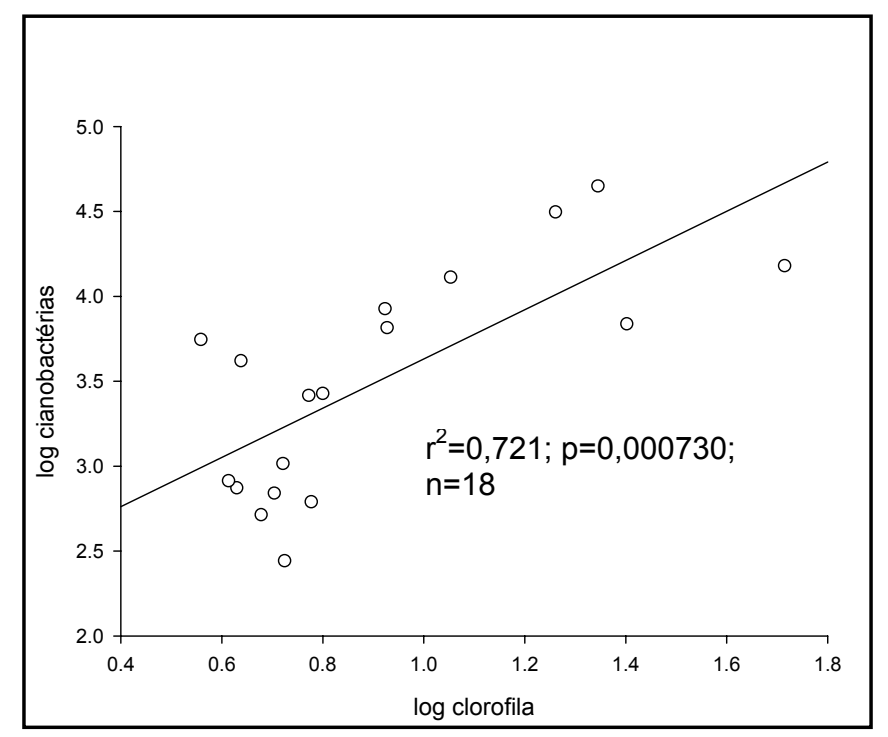

Figura 52: Correlação entre log de clorofila e log de cianobactérias para o reservatório de Itaipu, para o período de 1999 a 2004. 


\subsubsection{Análise da relação de cianobactérias com fósforo total e peixes no reservatório de Itaipu}

\subsubsection{Relação entre as concentrações de cianobactérias e guildas de peixes}

Para as variáveis que apresentaram correlação significativa (5\%) nas análises anteriores, foram testados inicialmente os modelos completos de ANCOVA no intuito de determinar se o fator zona do reservatório foi significativo (5\%).

\subsubsection{Relação entre concentração de cianobactérias e peixes onívoros}

A Figura 53 mostra a relação positiva entre lnciano e lnonivoro. Estas podem ser tomadas como lineares, embora com bastante dispersão ao longo da reta de tendência.

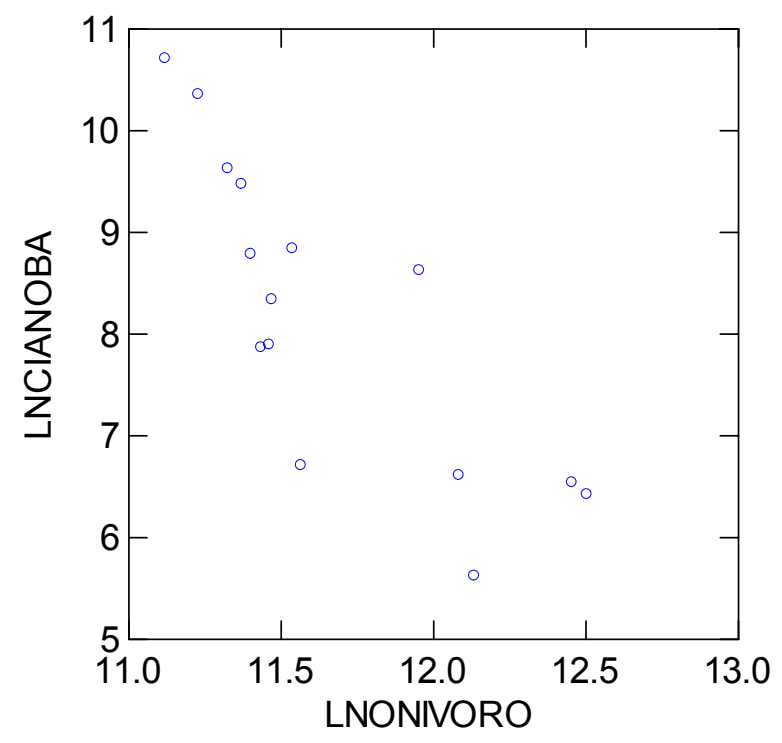

Figura 53: Relação entre lncianoba e lnonivoro (lncianoba é o logaritmo neperiano da concentração de cianobactérias e lnonivoro é o logaritmo neperiano do peso total dos peixes onívoros).

No modelo completo testado $\ln$ cianoba $=\mu+Z R+\ln$ onivoro $+\ln t k n+\ln p_{-}$total $+\varepsilon$ foram considerados $\operatorname{lncianoba}$ a variável dependente, o fator zona do reservatório com três níveis, e as covariáveis (variáveis independentes) discriminados abaixo.

Fator: 
$Z R$ : zona do reservatório (fluvial $=1 ;$ transição $=2$; lacustre $=3$ ).

Covariáveis:

lnonivoro: logaritmo neperinao do peso total dos peixes onívoros;

$\ln t k n$ : logaritmo neperiano de TKN;

$\ln p \_t o t a l:$ logaritmo neperiano da concentração de fósforo total.

Para o modelo $\ln$ cianoba $=\mu+Z R+\ln$ onivoro $+\ln t k n+\ln p_{-}$total $+\varepsilon$, as variáveis $\ln t k n$ e $\ln p \_t o t a l$ não forma significativas e foram, uma a uma, eliminadas do modelo. $\mathrm{O}$ modelo $\ln$ cianoba $=\mu+Z R+\ln$ onivoro $+Z R * \ln$ onivoro $+\varepsilon$ foi testado e a interação $Z R^{*} \ln$ onivoro não foi significativa a $5 \%$, as retas foram consideradas paralelas e essa interação foi eliminada do modelo. Na Tabela 13 é apresentado o modelo final da ANCOVA $\ln$ ciano $=\mu+Z R+\ln$ onivoro $+\varepsilon$.

Tabela 13: Resultados da ANCOVA aplicada no modelo $\ln$ ciano $=\mu+Z R+\ln$ onivoro $+\varepsilon$, para os dados das variáveis limnológicas e das guildas tróficas de peixes, onde $Z R$ é a zona do reservatório ( $1=$ fluvial; $2=$ transição; $3=$ lacustre) e lnonivoro é o logaritmo neperiano do peso total dos peixes onívoros e $\varepsilon$ é o erro experimental.

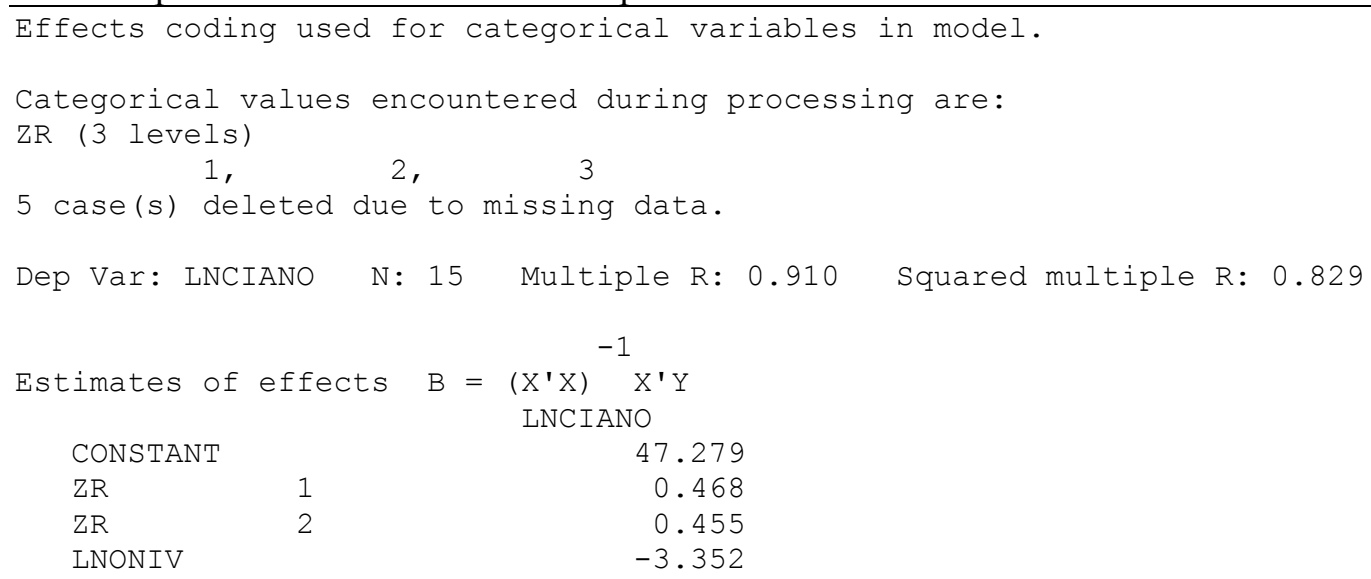

Analysis of Variance

\begin{tabular}{lccccc}
\hline Source & Sum-of-Squares & df & Mean-Square & F-ratio & P \\
\hline ZR & 5.640 & 2 & 2.820 & 5.477 & 0.022 \\
LNONIV & 3.883 & 1 & 3.883 & 7.541 & 0.019 \\
Error & 1.454 & 11 & 0.132 & & \\
\hline
\end{tabular}

O resultado da ANCOVA apresentado acima indica o efeito negativo dos peixes onívoros e das zonas do reservatório sobre as concentrações de cianobactérias. Para o modelo final foi feita uma análise de resíduos. Na Figura 54 observam-se os pontos dispersos de modo aleatório, sem que haja relação entre a distribuição dos resíduos studentizados e os valores estimados e a Figura 55 mostra o histograma dos resíduos do 
modelo final da ANCOVA. Os valores de probabilidade de Lilliefors para os resíduos foram de 0,341, aceitando-se a condição de normalidade ( $p>0,05)$.

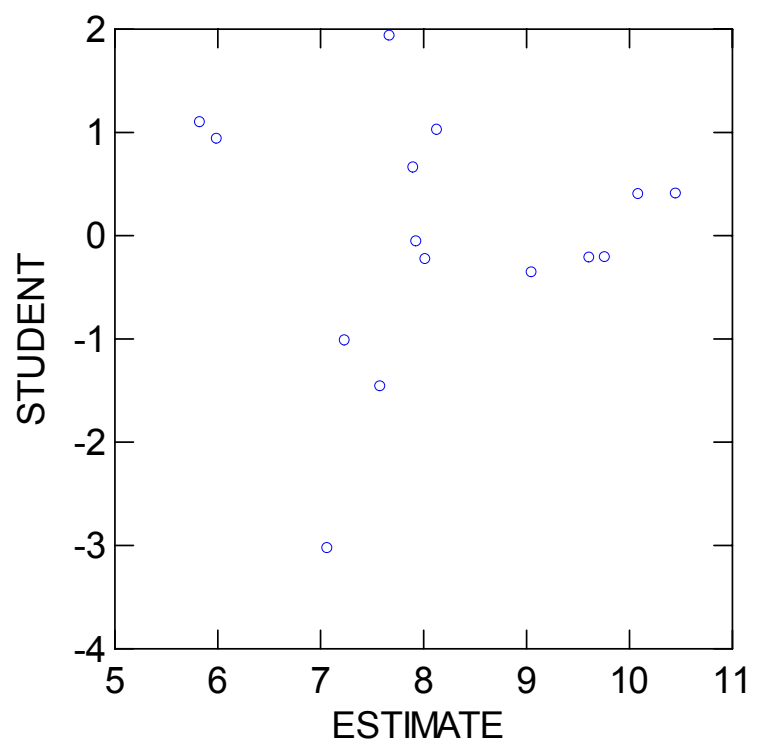

Figura 54: Distribuição dos resíduos studentizados em função dos valores estimados pelo modelo ANCOVA $\ln$ ciano $=\mu+Z R+\ln$ onivoro $+\varepsilon$, para os dados das variáveis limnológicas e das guildas tróficas de peixes, onde $Z R$ é a zona do reservatório (1=Fluvial, $2=$ Transição, $3=$ Lacustre), lnonivoro é o logaritmo do peso total dos peixes onívoros e $\varepsilon$ é o erro experimental.

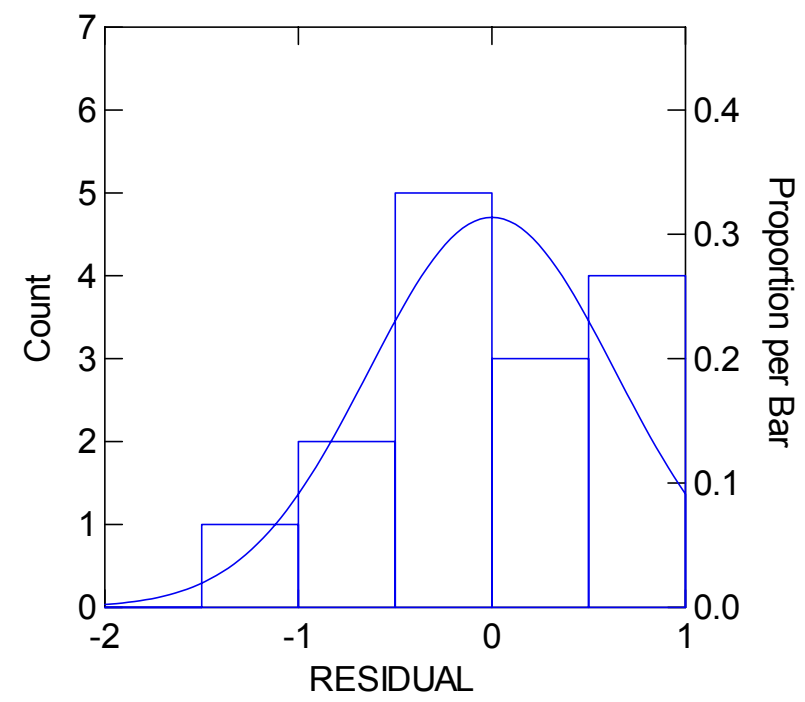

Figura 55: Histograma dos resíduos do modelo final da ANCOVA $\ln$ ciano $=\mu+Z R+\ln$ onivoro $+\varepsilon$, para os dados das variáveis limnológicas e das guildas tróficas dos peixes, onde $Z R$ é a zona do reservatório ( $1=$ Fluvial, $2=$ Transição, $3=$ Lacustre), lnonivoro é o logaritmo neperiano do peso total dos peixes onívoros e $\varepsilon$ é o erro experimental. 
O teste de comparação entre as médias mostrou não haver diferença estatística para as concentrações de clorofila entre as zonas do reservatório em relação ao peso de peixes detritívoros (Tabela 14). Na Figura 56 estão representadas as médias ajustadas das concentrações de clorofila.

Tabela 14: Teste a posteriori entre as médias ajustadas de lnciano (logaritmo neperiano da concentração de cianobactérias) obtidas a partir do modelo final da ANCOVA $\ln$ ciano $=\mu+Z R+\ln$ onivoro $+\varepsilon$ para as três zonas do reservatório (1= Fluvial; 2= Transição; $3=$ Lacustre). Os números entre parêntesis representam os antilogaritmos das médias ajustadas (concentração de cianobactérias), em escala aritmética.

\begin{tabular}{c|c|c}
\hline Comparação entre locais & $\begin{array}{c}\text { Média ajustada da concentração de cianobactérias } \\
\ln \overline{\text { ciano } \pm \text { ep }}\end{array}$ & Teste $\boldsymbol{L S D}$ \\
\hline 1 e 2 & $8,628(5585,9) \pm 0,751$ & $0,000 \mathrm{~ns}$ \\
\hline 1 e 3 & $8,615(5513,7) \pm 0,537$ & $0,035 \mathrm{~ns}$ \\
\hline 2 e 3 & $7,236(1388,5) \pm 0,406$ & $0,036 \mathrm{~ns}$ \\
\hline
\end{tabular}

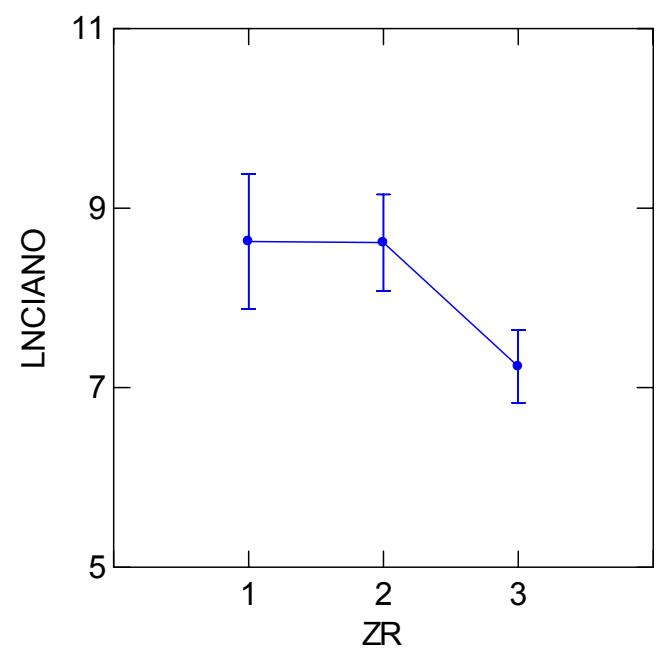

Figura 56: Médias ajustadas de lnciano para as zonas do reservatório, com 1 = Fluvial, $2=$ Transição e 3 = Lacustre. As barras verticais indicam o erro padrão da média ajustada.

\subsubsection{Relações entre concentração clorofila e detritívoros}

A Figura 57 mostra a relação positiva entre lncloro e lndetritivoro. Estas podem ser tomadas como lineares, embora com bastante dispersão. 


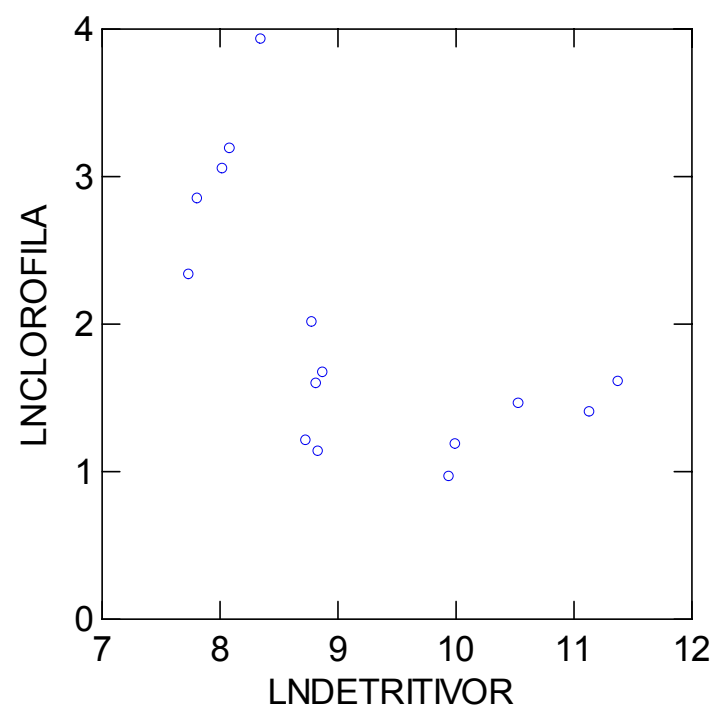

Figura 57: Relação entre lncloro e lndetritivoro (lncloro é o logaritmo neperiano da concentração de clorofila e lndetritivoro é o logaritmo neperiano do peso total dos peixes detritívoros).

No modelo $\ln$ clorofila $=\mu+Z R+\ln$ detritivor $+\ln t k n+\ln p \_$total $+\varepsilon$ testado foram considerados lnclorofila a variável dependente, o fator zona do reservatório com três níveis, e as covariáveis (variáveis independentes) discriminados abaixo.

Fator:

$Z R$ : zona do reservatório (fluvial $=1$; transição $=2$; lacustre $=3$ ).

Covariáveis:

lndetritivoro: logaritmo neperinao do peso total dos peixes detritívoros; $\ln t k n$ : logaritmo neperiano de TKN;

$\ln p_{\text {_total: }}$ logaritmo neperiano da concentração de fósforo total.

Para o modelo $\ln$ clorofila $=\mu+Z R+\ln$ detritivor $+\ln t k n+\ln p_{-}$total $+\varepsilon$ as variáveis $\ln t k n$ e $\ln p \_t o t a l$ não foram significativas e foram, uma a uma, eliminadas do modelo. O modelo $\ln$ clorofila $=\mu+Z R+\ln$ detritivor $+Z R * \ln$ detritivor $+\varepsilon$ foi testado e a interação $Z R^{*}$ Indetritivor não foi significativa a $5 \%$; as retas foram consideradas paralelas e essa interação foi eliminada do modelo. Na Tabela 15 é apresentado o modelo final da ANCOVA $\ln$ clorofila $=\mu+Z R+\ln$ detritivor $+\varepsilon$.

O resultado da ANCOVA apresentado acima indica o efeito dos peixes detritívoros e das zonas do reservatório sobre as concentrações de clorofila. Para o modelo final foi feita uma análise de resíduos. Na Figura 58 observam-se os pontos dispersos de modo aleatório, sem que haja relação entre a distribuição dos resíduos 
studentizados e os valores estimados e a Figura 59 mostra o histograma dos resíduos do modelo final da ANCOVA. Os valores de probabilidade de Lilliefors para os resíduos foram de 0,901 , aceitando-se a condição de normalidade $(\mathrm{p}>0,05)$.

Tabela 15: Resultados da ANCOVA aplicada no modelo $\ln$ cloro $=\mu+Z R+\ln$ detritivor $+\varepsilon$, para os dados das variáveis limnológicas e das guildas tróficas de peixes, onde $Z R$ é a zona do reservatório ( $1=$ fluvial; $2=$ transição; $3=$ lacustre) e lndetritivor é o logaritmo neperiano do peso total dos peixes detritívoros e $\varepsilon$ é o erro experimental.

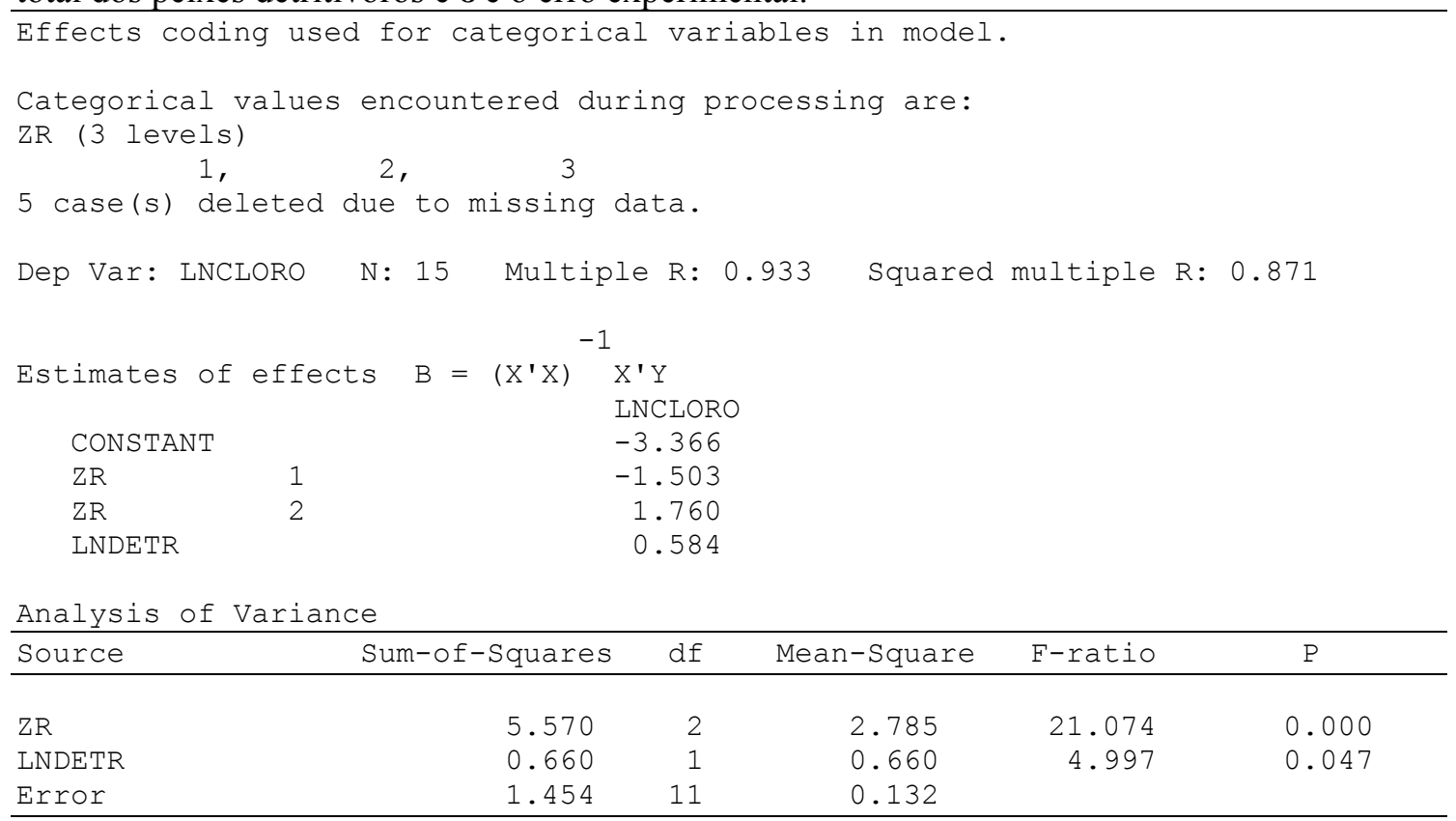

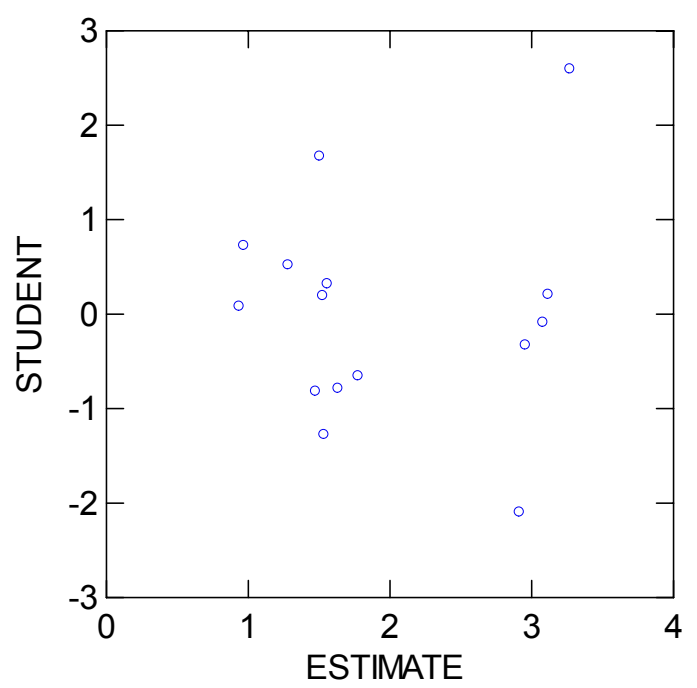

Figura 58: Distribuição dos resíduos studentizados em função dos valores estimados pelo modelo ANCOVA $\ln$ clorofila $=\mu+Z R+\ln$ detritivoro $+\varepsilon$, para os dados das variáveis limnológicas e das guildas tróficas de peixes, onde $Z R$ é a zona do reservatório (1= Fluvial, $2=$ Transição, $3=$ Lacustre), lndetritivor é o logaritmo do peso dos peixes detritívoros e $\varepsilon$ é o erro experimental. 


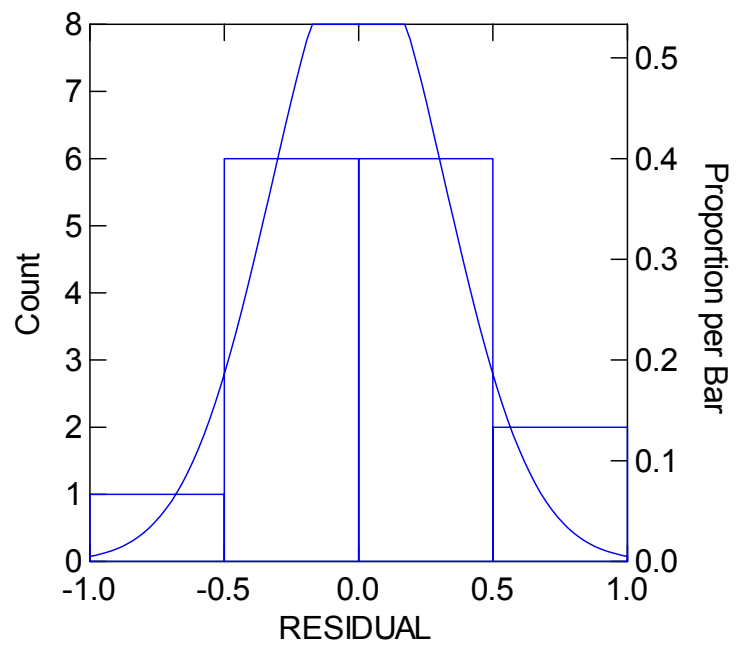

Figura 59: Histograma dos resíduos do modelo final da ANCOVA $\ln$ clorofila $=\mu+Z R+\ln$ detritivor $+\varepsilon$, para os dados das variáveis limnológicas e das guildas tróficas dos peixes, onde $Z R$ é a zona do reservatório (1= Fluvial, $2=$ Transição, $3=$ Lacustre), lndetritivor é o logaritmo neperiano do peso dos peixes detritívoros e $\varepsilon$ é o erro experimental.

O teste de comparação entre as médias mostrou não haver diferença estatística para as concentrações de clorofila entre as zonas do reservatório em relação ao peso de peixes detritívoros (Tabela 16). Na Figura 60 estão representadas as médias ajustadas das concentrações de clorofila.

Tabela 16: Teste a posteriori entre as médias ajustadas de lnclorofila (logaritmo neperiano da concentração de clorofila) obtidas a partir do modelo final da ANCOVA $\ln$ cloro $=\mu+Z R+\ln$ detritivor $+\varepsilon$ para as três zonas do reservatório (1= Fluvial; 2= Transição; $3=$ Lacustre). Os números entre parêntesis representam os antilogaritmos das médias ajustadas (concentração de clorofila), em escala aritmética.

\begin{tabular}{c|c|c}
\hline Comparação entre locais & $\begin{array}{c}\text { Concentração de clorofila média ajustada } \\
\ln \overline{\text { cloro }} \pm \mathrm{ep}\end{array}$ & Teste $\boldsymbol{L S D}$ \\
\hline 1 e 2 & $0,468(1,60) \pm 0,415$ & $0,244 \mathrm{~ns}$ \\
\hline 1 e 3 & $3,738(42,01) \pm 0,338$ & $0,089 \mathrm{~ns}$ \\
\hline 2 e 3 & $1,715(5,56) \pm 0,184$ & $0,167 \mathrm{~ns}$ \\
\hline
\end{tabular}




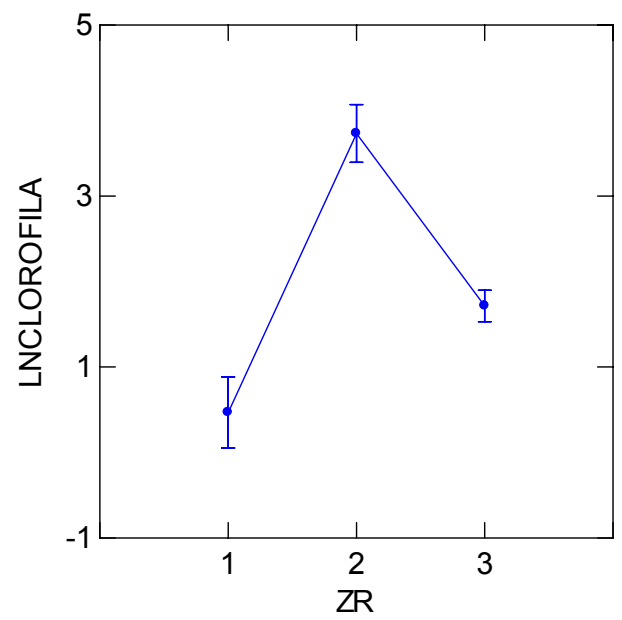

Figura 60: Médias ajustadas de lnclorofila para as zonas do reservatório, com 1 = Fluvial, $2=$ Transição e 3 = Lacustre. As barras verticais indicam o erro padrão da média ajustada.

\subsection{Inferência da produção pesqueira}

A Figura 61 representa a regressão entre a captura e os valores logaritimizados das densidades de cianobactéria. Esta relação se mostrou negativa, indicando a depleção da captura pelo aumento das cianobactérias, cujos valores do coeficiente de correlação explicam $49 \%$ do modelo a 0,05 de significância.

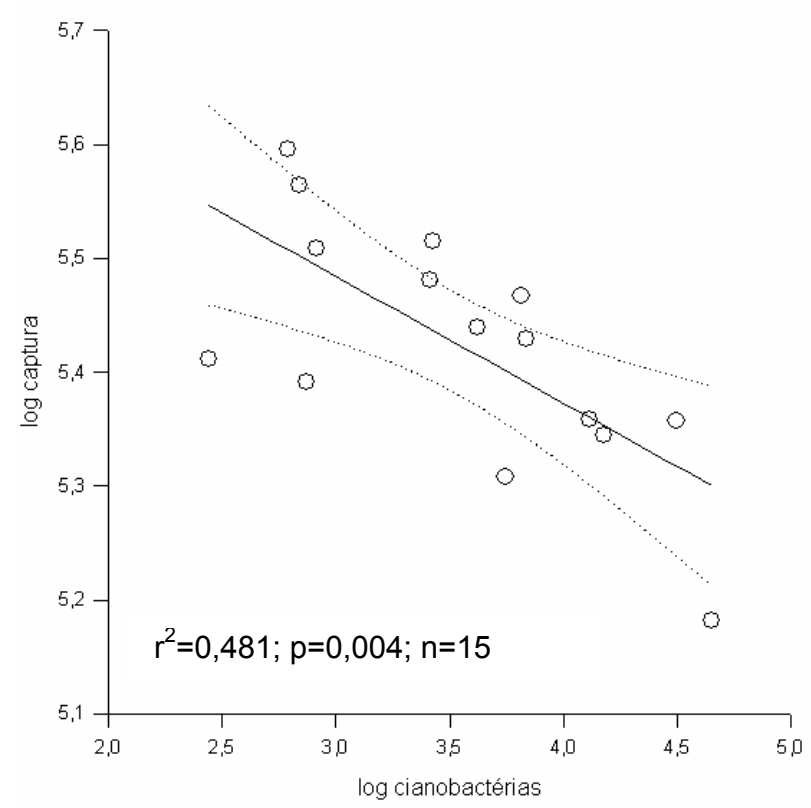

Figura 61: Análise da regressão entre log de cianobactérias e log de captura, para o reservatório de Itaipu, no o período de 2000 a 2004. 
Tabela 17: Resultados da análise de regressão aplicada no modelo $\ln$ captura $=\mu+\ln$ cianobactéria $+\varepsilon$, onde lncaptura é o logaritmo neperiano da captura, Incianobactéria é ologaritmo neperiano da concentração de cianobactéria e $\varepsilon$ é o erro experimental.

\begin{tabular}{lrrrrrr}
\hline Dep Var: LOGCIANO & N: 15 & Multiple R: & 0.693 & Squared multiple R: & 0.481 \\
\hline Effect & Coefficient & Std Error & Std Coef & Tolerance & t & P \\
\hline CONSTANT & 27.099 & 6.790 & 0.000 &. & 3.991 & 0.002 \\
LOGCAPTURA & -4.343 & 1.252 & -0.693 & 1.000 & -3.469 & 0.004 \\
\hline
\end{tabular}

Para o este modelo foi feita uma análise de resíduos. Na Figura 62a observam-se os pontos dispersos de modo aleatório, sem que haja relação entre a distribuição dos resíduos e com os valores estimados e a Figura 62 b mostra o histograma dos resíduos do modelo final da regressão. Os valores de probabilidade de Lilliefors

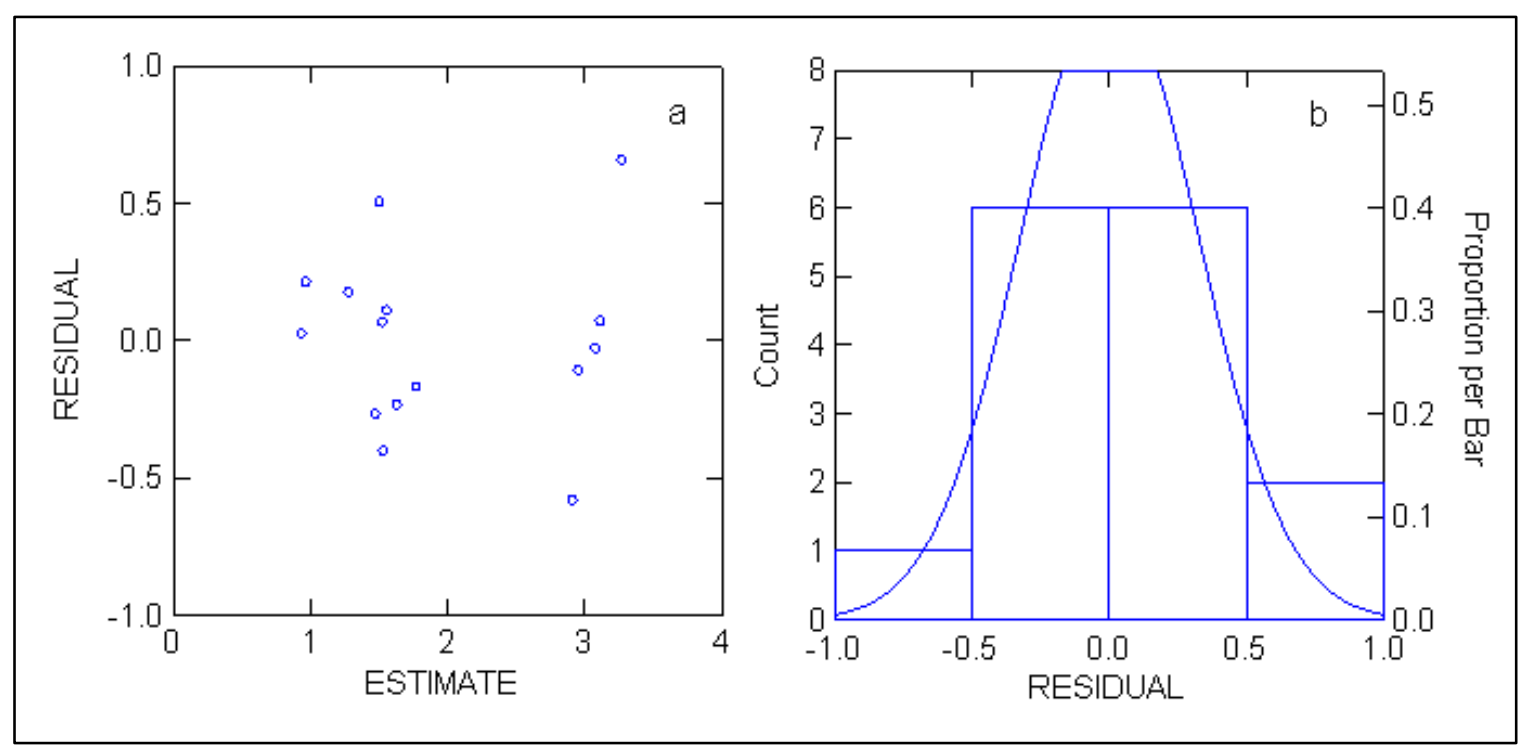

Figura 62: Distribuição dos resíduos (a) e histograma dos resíduos (b) do modelo da regressão $\ln$ captura $=\mu+\ln$ cianobactérias $+\varepsilon$, onde lncaptura é o logaritmo neperiano da captura, lncianobactérias é o logaritmo neperiano das concentrações de cianobactérias e $\varepsilon$ é o erro experimental.

Os resultados da inferência da produção pesqueira por meio de modelos empíricos para reservatório de Itaipu estão representados na Figura 63. De acordo com esta inferência, o reservatório apresentou uma produtividade pesqueira média de $8,1 \mathrm{~kg} / \mathrm{ha} /$ ano. As zonas de transição e fluvial apresentaram as maiores produtividades médias $(8,2 \mathrm{~kg} / \mathrm{ha} / \mathrm{ano})$, enquanto que na zona lacustre obteve-se uma produtividade média de $8,1 \mathrm{~kg} / \mathrm{ha} / \mathrm{ano}$. 


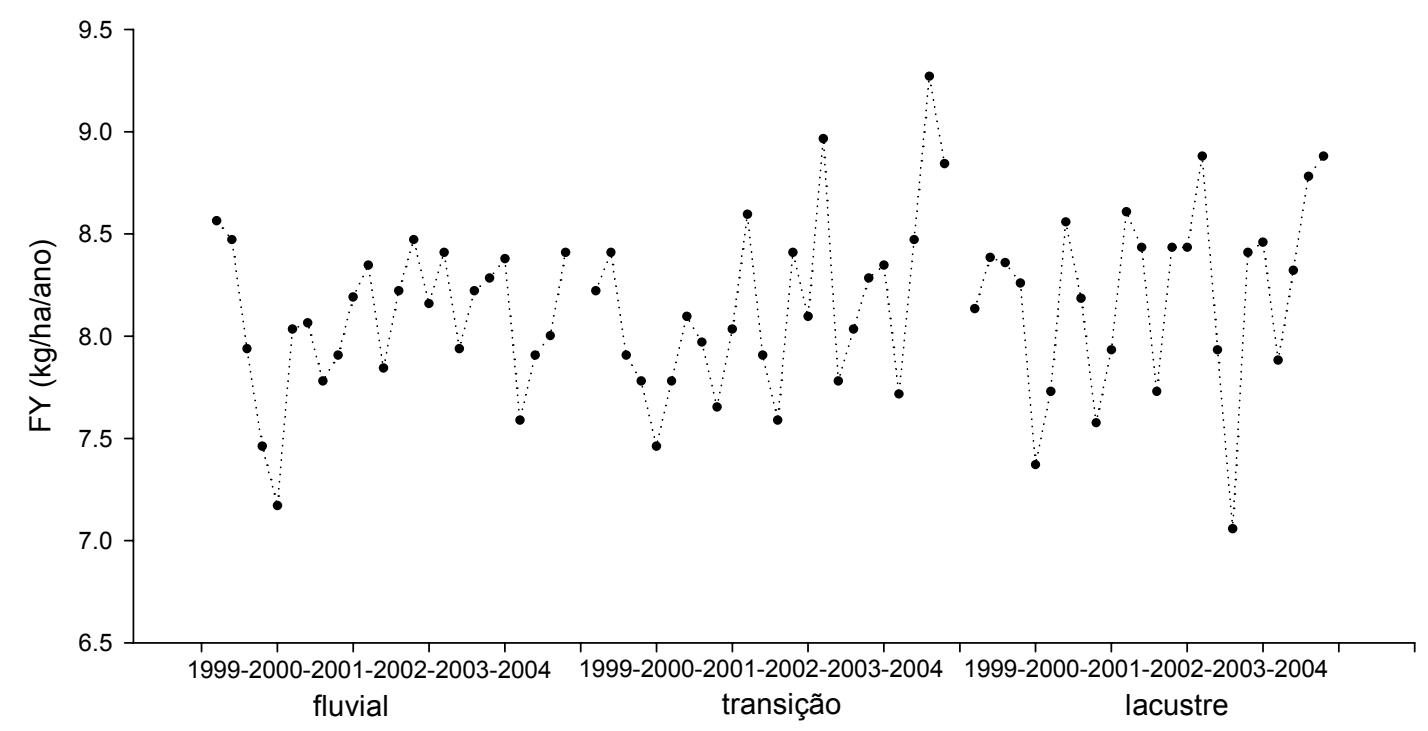

Figura 63: Estimativa da produtividade pesqueira (FY) em kg/ha/ano de acordo com as zonas do reservatório de Itaipu, para o período de 1999 a 2004.

\subsubsection{Correlações entre MEI, clorofila-a e transparência da água}

A Figura 64 apresenta os resultados das correlações entre os valores de transparência da água e das concentrações de clorofila-a com os valores do MEI, indicando que a diminuição da transparência da água está associado a um aumento do MEI (Figura 64a). Para a comparação entre a clorofila e o MEI, observa-se uma relação inversa à anterior, onde o aumento da concentração de clorofila está relacionado com o aumento do MEI (Figura 64b).

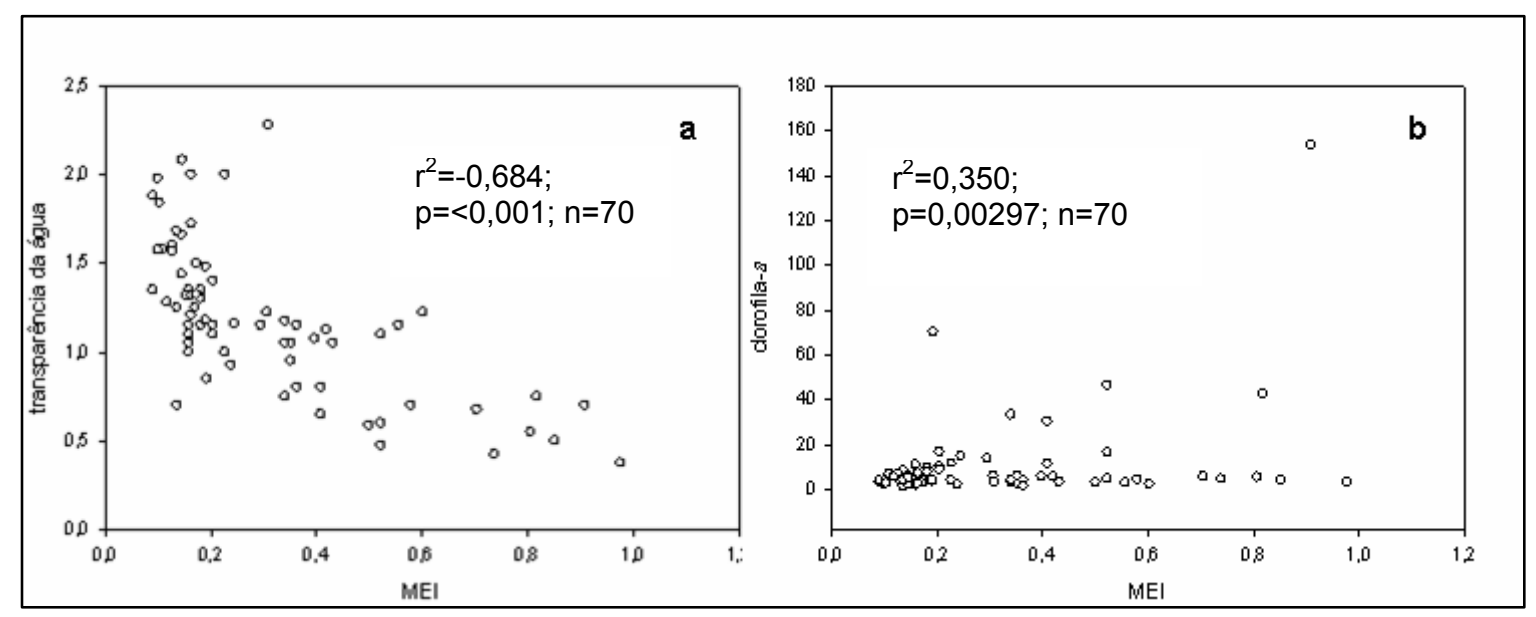

Figura 64: Análise de correlação entre a transparência da água (a) e clorofila-a (b) com o índice morfedáfico (MEI) para o reservatório de Itaipu, para o período de 1999 a 2004. 


\section{DISCUSSÃO}

\subsection{Limnologia do reservatório de Itaipu}

As variáveis limnológicas são de fundamental importância para caracterizar as zonas de um reservatório. De acordo com a variação longitudinal das mesmas, onde todo aporte de material alóctone e autóctone sedimenta-se no ambiente, um reservatório apresenta essencialmente três zonas bem características: a região lótica, a região de transição e a lacustre (KIMMEL, 1990). Estas regiões têm uma distribuição horizontal espacial, com dinâmica própria, sofrendo a influência da entrada dos rios e da saída da água pelos vertedouros $\mathrm{e}$ turbinas. $\mathrm{O}$ autor salienta que ocorre uma compartimentalização temporal, que dependendo do fluxo horizontal na superfície, é sujeita à ação de ventos e distribuição de massas d'água com densidades diferentes. Segundo TUNDISI (op.cit), a distribuição horizontal das variáveis em um reservatório está relacionada com os seguintes fatores: correntes de advecção provocada pela entrada dos rios, correntes de superfície produzidas pela ação dos ventos e correntes produzidas pelo fluxo horizontal, resultante da saída de massas de água a várias profundidades.

O reservatório de Itaipu apresenta fortes relações entre as zonas fluvial, transição e lacustre. Segundo THORNTON (1990) estas relações sugerem que as variabilidades sazonais são explicadas pelo processo hidrodinâmico, principalmente as descargas que o Rio Paraná sofre, influenciando uma dinâmica irregular para as variáveis limnológicas. De acordo com o autor, o reservatório de Itaipu apresentou variações bem distintas em relação à suas zonas e o transporte e deposição de partículas tiveram influências nos processos ecológicos.

As análises indicam que o reservatório de Itaipu apresenta heterogeneidade espacial horizontal para algumas variáveis limnológicas e biológicas. A sazonalidade na distribuição da precipitação se mostra de maneira bem clara e na zona de transição as chuvas foram mais freqüentes. Este fato pode explicar porque esta zona apresenta 
concentrações de nutrientes mais elevadas. Quando se analisa o mapa topográfico do vale do lago de Itaipu (Figura 65) (STIVARI et al., 2005), fica evidenciado que a topografia da zona de transição favorece o aumento de vazões na mesma (TUCCI, 2002), explicando assim um maior aporte de material alóctone para o reservatório.

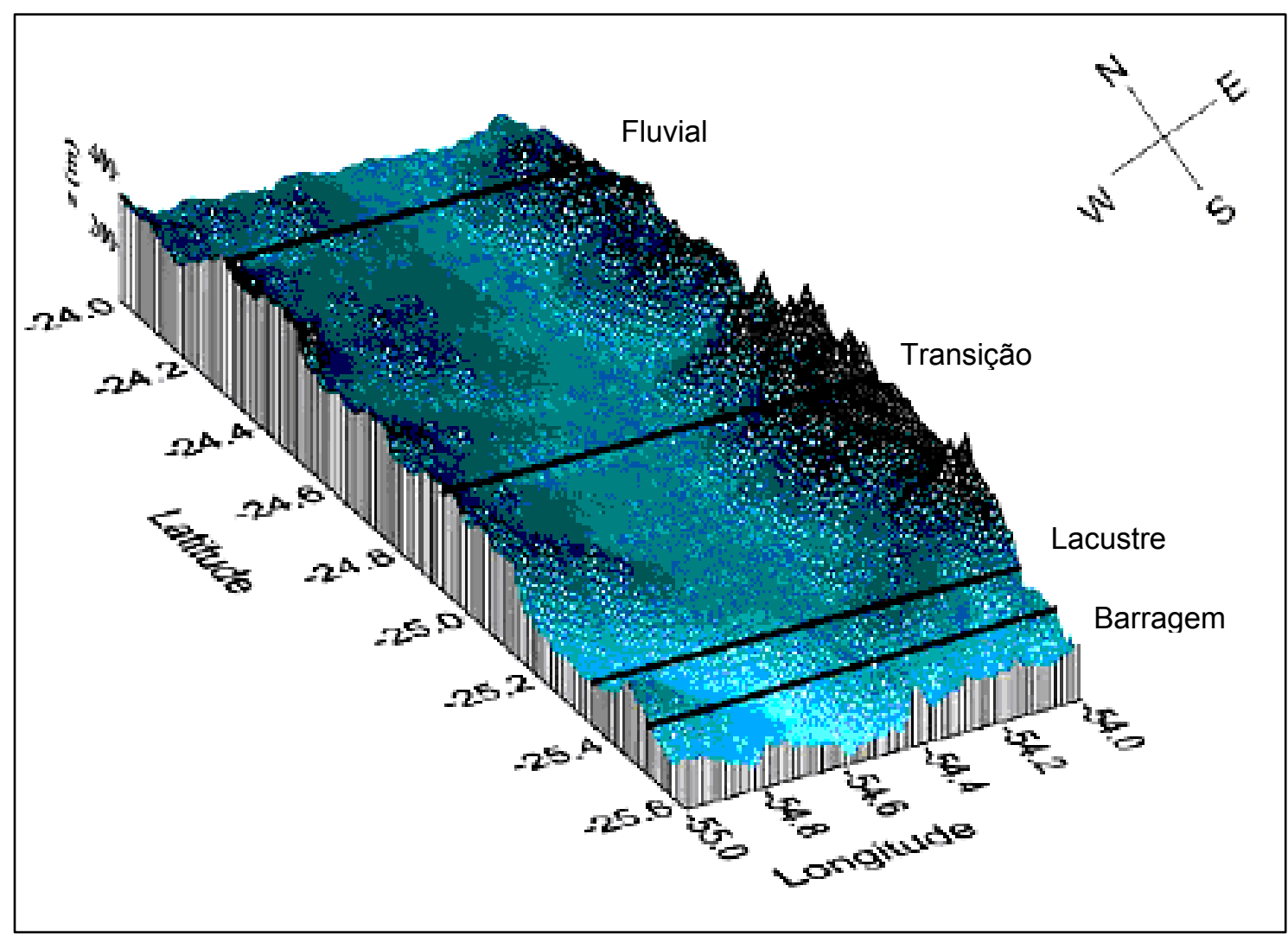

Figura 65: Mapa topogáfico do vale do reservatório de Itaipu. O lago de Itaipu está localizado na porção central do vale. As linhas horizontais representam a latitude das estações meteorológicas (fonte: STIVARI et al., 2005).

FERRAREZE et al. (2005), em diferentes trechos do rio Paranapanema e seus tributários, avaliaram o transporte de nutrientes e material em suspensão. Os resultados elucidam a importância do ciclo hidrológico, em particular a precipitação, e das dimensões laterais e longitudinais.

O uso e ocupação da terra é um fator de extrema importância em estudos de reservatórios. Atividades como a monocultura e grandes áreas de pasto podem aumentar as concentrações de nutrientes no ecossistema aquático. Ao analisar a Figura 66, observa-se que nas margens do reservatório, do lado brasileiro, existem extensas áreas que contribuem para a aceleração do processo de eutrofização do reservatório (poluição difusa), enquanto no lado paraguaio ainda existem grandes áreas de florestas ao longo do reservatório. 
Um estudo no reservatório de São Simão (MG) mostrou que as maiores concentrações de nutrientes e sólidos foram encontradas nos rios onde existia atividade agrícola e pecuária (PINTO COELHO et al., 2005). O mesmo efeito pode ser observado nos reservatórios em cascata do rio Paranapanema (NOGUEIRA et al., 2005).

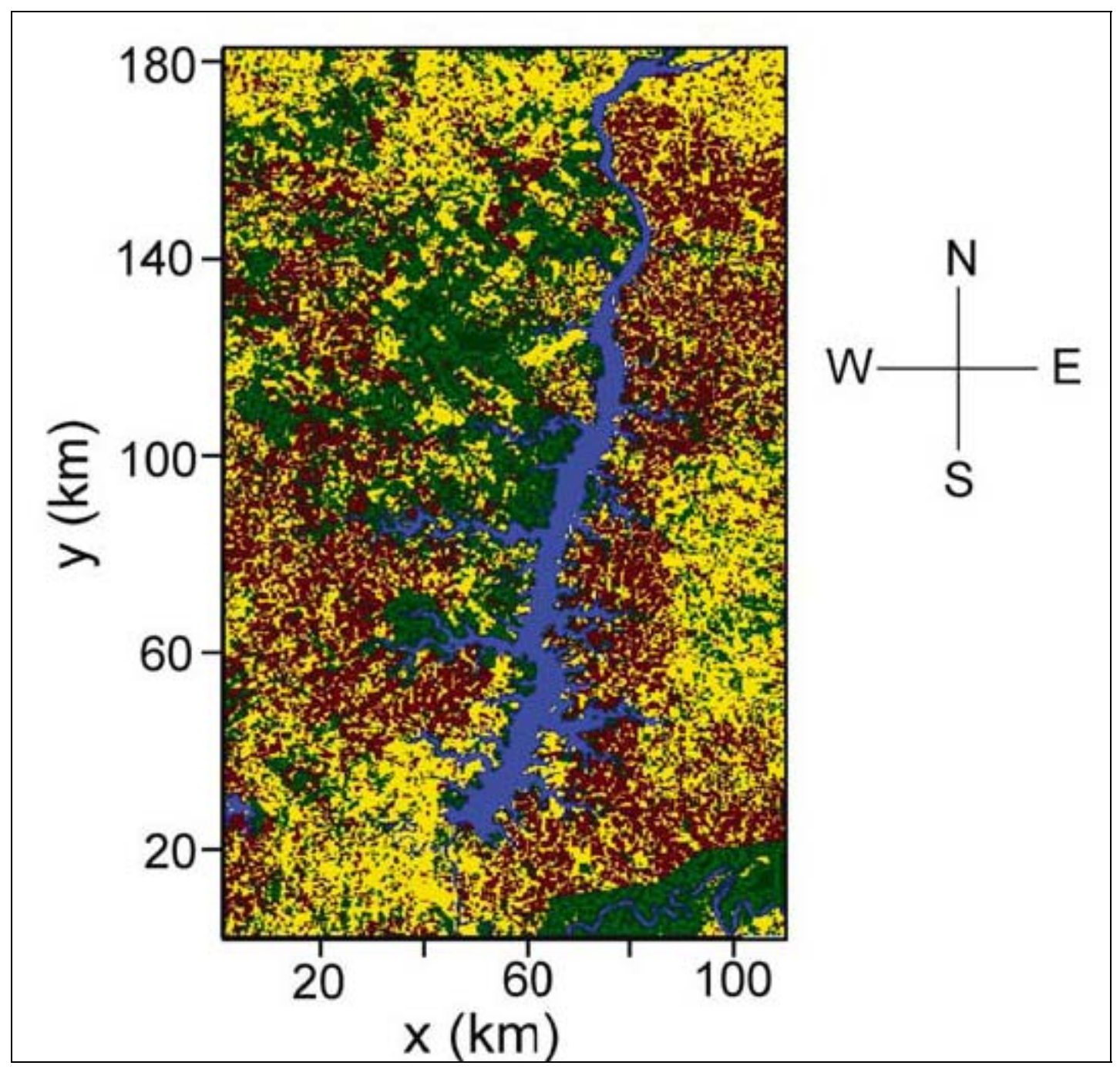

Figura 66: Distribuição do uso da terra nas áreas próximas do reservatório de Itaipu, apresentando quatro classes dominantes: lago e rios (azul); floresta (verde); pasto (amarelo) e atividade de agricultura (vermelho) (Fonte: STIVARI et al., 2005).

A temperatura é uma das variáveis de maior importância (a) na distribuição e fisiologia de organismos aquáticos, podendo causar altercações na dinâmica dos nutrientes na coluna da água (ESTEVES, 1988) e (b) em estudos de cadeia trófica e biomanipulação em lagos e reservatórios, influenciando as taxas metabólicas dos peixes (JEZIERSKA, 1979). As taxas de excreção de amônia aumentam com a elevação desta variável (IWAKUMA et al., 1990) e a ciclagem do fósforo pelos peixes é acelerada (ANDERSSON et al., 1988; PERSSON, 1997). No reservatório de Itaipu a temperatura 
da água apresentou um padrão de variação sazonal, com as maiores temperaturas registradas entre novembro e março e as menores de maio a agosto. A maior temperatura foi encontrada na zona lacustre $\left(30,4^{\circ} \mathrm{C}\right)$ Estes resultados são similares aos encontrados por AGOSTINHO et al. (1997b) e ANDRADE et al. (1988), e em reservatórios localizados na Serra do Mar, no estado do Paraná (PAGIORO et al., 2005a).

A transparência da água apresenta uma forte influência no estado trófico dos ambientes aquáticos, e a penetração de luz determina o desenvolvimento de organismos fitoplânctônicos e, por conseqüência, o enriquecimento do ambiente (ESTEVES, 1988; WETZEL, 1990; HENRY, 1990).

Além do aporte de material alóctone, que é transportado e sedimentado na água, contribuindo para a redução da transparência água, as altas biomassas de peixes também podem diminuir a transparência da água (SHAPIRO et al., 1975; MCQUEEN et al., 1990; SONDERGAARD et al., 1997) devido ao acréscimo de nutrientes via excreção dos peixes (DRENNER et al., 1996; STARLING, 1998).

No reservatório de Itaipu as menores transparências da água foram registradas na zona fluvial devido ao transporte de partículas e taxas de sedimentação, que é diretamente associado à vazão dos cursos d'água. A análise dos dados de sólidos suspensos indica que na medida em que esta variável diminui, a transparência da água aumenta, conforme já observado por ANDRADE et al. (1988) e AGOSTINHO et al. (1997).

Os valores de transparência da água foram relacionados com as variáveis limnológicas e os resultados indicam que as variáveis turbidez e sólidos suspensos influenciaram negativamente a transparência da água. Isto é explicado porque quando as variáveis independentes aumentam de valor, a variável dependente aumenta, interferindo diretamento na quantidade de energia luminosa para o sistema.

A concentração de sólidos em suspensão na água, além do ciclo hidrológico e turbidez, também constitui um dos fatores mais importantes e limitante para a produção primária em ambientes que apresentam altos valores desta variável, influenciando no comportamento fotossintético e causando alterações na ecologia do ecossistema (CALIJURI \& TUNDISI, 1990). É importante salientar que fatores climáticos, como a pluviosidade, desempenham um papel importante principalmente em relação à variável transparência da água. Os resultados das análises entre a pluviosidade e a transparência da água demonstram o efeito negativo, sendo de grande importância a mensuração desta 
variável para a produtividade dos ambientes aquáticos. SOUZA FILHO \& STEVAUX (1997) ressaltam que a descarga de sólidos no rio Paraná foi em torno de 30 milhões de toneladas por ano, das quais apenas $10 \%$ se referem à carga de fundo. A carga suspensa varia de acordo com os picos de cheias (precipitação).

A turbidez da água é a medida que expressa a perda de penetração da luz no ambiente aquático, pois é o reflexo de todo o material orgânico e inorgânico que está em suspensão na água na forma particulada (WETZEL, 2001). No reservatório de Itaipu esta variável apresentou valores bem próximos entre as zonas fluvial, transição e lacustre, embora tenha apresentado valores médios decrescentes no sentido montantejusante, corroborando com os resultados de ANDRADE et al. (1988). Os valores mais elevados de turbidez podem ser explicados por eventuais períodos de chuvas em períodos anteriores e durante a coleta, como observado por ZANATA (1999) no reservatório de Salto Grande (Americana, SP) e por PINTO COELHO et al. (2005) no reservatório de São Simão (MG). Esta variável é muito importante pelo fato de várias espécies de peixes predadores apresentarem tática de alimentação visual e de perseguição ativa (RIBEIRO FILHO, 1999), promovendo a ressuspensão de detritos orgânicos e inorgânicos ao se locomoverem para a captura de alimento (PEDRO, 1995). Esta variável está relacionada diretamente com a diminuição da vazão, implicando num menor aporte de materiais em suspensão da água.

Segundo ESTEVES (1998), o pH representa o balanço iônico dentro do ambiente aquático, interferindo diretamente sobre as condições de neutralidade das águas e capacidade de tamponamento do ambiente (alcalinidade). $\mathrm{O}$ aumento desta variável pode estar relacionado com as mudanças nos valores de alcalinidade em ecossistemas aquáticos, explicando as relações inversas dos valores encontrados de alcalinidade com o $\mathrm{pH}$. O reservatório de Itaipu apresentou-se, em geral, um $\mathrm{pH}$ alcalino com pequena tendência à neutralidade, resultados estes consoantes com os de AGOSTINHO et al. (1997a). O fato da zona de transição apresentar maiores valores de $\mathrm{pH}$ pode estar relacionado com a maior atividade fotossintética (cianobactérias) nesta região (VOLLENWEIDER, 1974). SHAPIRO \& WRIGHT (1984), em estudo experimental, verificou que as concentrações de $\mathrm{pH}$ e $\mathrm{CO}_{2}$ são variáveis que ajudam a determinar as populações de cianobactérias.

A condutividade elétrica é a capacidade de transmitir eletricidade no corpo aquático, refletindo de maneira indireta o grau de sólidos dissolvidos na água. Em alguns estudos o aumento da condutividade foi acompanhado pelo aumento de 
cianobactérias (RAMIREZ, 1996). No reservatório de Itaipu a maior condutividade foi registrada na zona de transição, embora discreta. A presença exclusiva de tilápias, quando comparada a tratamentos sem a presença de peixes, em estudos de STARLING \& ROCHA (1990) e FIGUEREDO (2000), teve como resposta um aumento nos valores da condutividade elétrica. A concentração de íons na zona lacustre pode ser explicada pela maior biomassa de espécies piscívoras, justificada pelo controle de biomassas de onívoros (RIBEIRO FILHO, 2002).

O oxigênio dssolvido no ecossistema aquático é um fator limitante, tanto para a ciclagem de nutrientes como para a produtividade primária (AGOSTINHO et al., 1997a). No presente estudo foi observado um padrão na sua distribuição em relação à sazonalidade durante os meses coletados, corroborando com os resultados encontrados por AGOSTINHO et al. (1999), nos quais as menores concentrações de oxigênio dissolvido foram encontradas no verão (janeiro a março) e as maiores no período de chuva (junho a agosto). Para este trabalho, o maior valor de oxigênio dissolvido na zona de transição pode estar associado ao grande desenvolvimento das algas, principalmente as cianobactérias. O mês de março, para todos os anos, foi o que apresentou as menores concentrações deste gás, pois sofre forte influência da temperatura da água (nos meses mais quentes ocorre perda de OD para a atmosfera e aumento do metabolismo do ambiente).

Em um estudo desenvolvido por MINILLO (2005) em reservatórios do médio e baixo rio Tiete (SP) foram encontradas altas concentrações de oxigênio dissolvido na superfície da água. $\mathrm{O}$ autor salienta que estes resultados podem estar relacionados com os meses de chuvas e outros estudos também enfatizam o efeito da pluviosidade no padrão de distribuição do oxigênio dissolvido (TOWNSEND, 1999).

A variável DBO representa a quantidade de oxigênio necessária para oxidar a matéria orgânica por decomposição microbiana. Os aumentos nos valores desta variável representam um aumento de poluição orgânica ou pontual (CETESB, 2006). Em nenhum momento, em toda a variação longitudinal do reservatório de Itaipu, os valores de DBO ultrapassaram os estabelecidos pela resolução CONAMA 357/05 para ambientes de classe 2. A zona de transição foi a que apresentou maiores valores médios devido, provavelmente, à atividade de suinocultura no trecho correspondente na bacia hidrográfica (BENASSI, S.F., comunicação pessoal, 2006).

A variável DQO expressa a quantidade de oxigênio necessária para oxidar a matéria orgânica por meio de agentes químicos. O aumento de valores de DQO nos 
corpos hídricos são indícios de poluição industrial (CETESB, 2006). Como ocorreu com a DBO, a DQO apresentou uma maior concentração média na zona de transição $(7,5 \mathrm{mg} / \mathrm{L})$, o que também pode estar associado aos aportes de materiais ao reservatório.

O nitrogênio e o fósforo são os principais nutrientes para os produtores primários no ambiente aquático (ESTEVES, 1988) e o aumento médio de nutrientes significa mudanças na abundância de peixes, no que se refere à biomassa e composição, em lagos temperados (MCQUEEN, 1998). A biomassa de peixes e sua densidade por unidade de área do lago aumentam com o aumento da concentração de fósforo total (HANSON \& LAGGET, 1982; QUIROS, 1990), fazendo com que a concentração de peixes predadores seja reduzida (JEPPESEN et al., 1990; PERSSON et al., 1988).

Dentre as formas nitrogenadas mais consumidas pelas comunidades dos ecossistemas aquáticos estão o nitrogênio amoniacal, nitrato e nitrito. $\mathrm{O}$ nitrito é o estado intermediário entre a amônia e nitrato, durante o processo de nitrificação, sendo pouco disponível no meio e utilizado pelos produtores primários. O nitrito é uma variável bastante complexa, pelo fato de ser convertido em amônia ou nitrato e dificilmente se acumular no sistema, explicando a ausência de relação com a clorofila. Suas baixas concentrações podem ainda indicar um ambiente com elevada oxigenação (ESTEVES, 1988).

As concentrações de nitrato no reservatório apresentaram uma distribuição longitudinal horizontal. Os resultados encontrados foram semelhantes àqueles encontrados anteriormente no reservatório de Itaipu (AGOSTINHO et al., 1999), porém em concentrações inferiores.

O nitrogênio amoniacal é a forma nitrogenada mais reduzida e uma das mais utilizadas pelos produtores primários. Isto ocorre porque o íon amônio pode ser utilizado como fonte de nitrogênio durante a síntese de proteínas, pelos produtores primários. Isto pode acontecer por ser a amônia uma das principais formas de nitrogênio excretadas pelos peixes (WETZEL, 1993). No reservatório de Itaipu a concentração média desta variável foi de $0,03 \mathrm{mg} / \mathrm{L}$, corroborando com os resultados de AGOSTINHO et al. (1997b), com valores médios de 0,033mg/L.

O nitrogênio total kjeldahl (TKN) representa a soma das formas de nitrogênio orgânico e amoniacal, que são de extrema importância para a atividade biológica. No reservatório de Itaipu esta forma de nutriente foi a que apresentou a melhor relação com as concentrações de clorofila- $a$, e relações positiva com a transparência da água, comprovada pela análise de correlação. As concentrações de nitrogênio total kjeldahl no 
reservatório tiveram distribuição horizontal semelhante à encontrada por AGOSTINHO et al. (1999) e ANDRADE et al. (1988), com a zona de transição apresentando maiores concentrações deste nutriente. Esta variável foi a que melhor se relacionou com a variável clorofila, corroborando os resultados encontrados por BINI (2003), demonstrando assim a assimilação desta fonte de nitrogênio pelo fitoplâncton (REYNOLDS, 1984; ESTEVES, 1988). A relação entre as formas de nitrogênio e a clorofila também foi observada por KURMAYER \& WANZENBOCK (1996) e KARJALAINEN et al. (1998), os quais observaram relações diretas entre as reduções nas concentrações de nitrato e amônia e acréscimos nas concentrações de clorofila, em experimentos em tanques com biomassas de peixes conhecidas.

O fósforo é encontrado no ambiente aquático da mesma maneira que o nitrogênio (orgânico e inorgânico/ particulado dissolvido) e juntos são os nutrientes mais importantes para a produção primária em ecossistemas aquáticos. A menor concentração média na região lacustre do reservatório de Itaipu pode ser explicada pelas taxas de sedimentação ao longo do curso da água. É importante salientar que nesta zona o P.total pode ter mais efeito na produtividade (clorofila- $a$ ) pelo fator luminosidade (PAGIORO \& THOMAZ, 2002). Este fato explica porque o fósforo não teve relação significativa quando relacionado com a clorofila- $a$ e a transparência da água, nas analises de covarância para o reservatório de Itaipu.

Comparando as concentrações de fósforo total com os resultados de AGOSTINHO et al. (1999) e ANDRADE et al. (1988), observa-se que o reservatório apresentou um padrão de distribuição longitudinal sazonal semelhante em ambos os estudos. As concentrações deste nutriente foram semelhantes nas zonas de estudo, como demonstrou AGOSTINHO et al. (op.cit.), demostrando que a constância de reduzidas concentrações do fósforo total é uma importante implicação para a ausência da eutrofização no reservatório de Itaipu. TUNDISI et al. (1993) salientam que a inibição do processo de eutrofização pode estar associado à retenção deste nutriente em reservatórios de sistemas de cascata localizados a montante do reservatório de Itaipu, e estudos realizados por NOGUEIRA et al (2005) comprovam a diminuição de fósforo em reservatórios em sistemas de cascata. Além disso, AGOSTINHO et al. (1999) destacam que grandes fontes que carregam o fósforo para o reservatório são limitadas pelos tributários e pelas planícies de inundação.

O impacto de peixes que se alimentam de detritos do sedimento, tornando disponíveis grandes concentrações de fósforo para o fitoplâncton, foi estudado por 
vários autores (LAMARRA, 1975; DRENNER et al., 1996; PERSSON, 1997; STARLING, 1998). No Lago Paranoá este impacto foi observado em relação ao estoque de tilápias: devido a seu hábito alimentar onívoro, mais de 50\% do seu conteúdo estomacal foi composto por sedimento no estudo de GRANDO (1989), que através de excreção é lançado na coluna da água, aumentando a concentração de fósforo (PEREIRA \& RIBEIRO FILHO, 2004).

A produtividade primária, que pode ser expressa indiretamente pela concentração da clorofila, é controlada pela ação dos fatores a luz e nutrientes (HENRY \& SIMÃO, 1990), considerados fundamentais para o desenvolvimento da produtividade fitoplanctônica nos ecossistemas dulciaquículas.

A distribuição horizontal das concentrações de clorofila- $a$ no reservatório de Itaipu apresentaram relações significativas com algumas formas de nutrientes. A análise de covariância indica que o nitrogênio amoniacal afeta negativamente a produtividade primária, enquanto o nitrogênio total kjeldahl afeta positivamente a produtividade primária (Tabela 5). Estes resultados corroboram os de PAGIORO et al. (2005b) em seis reservatórios no estado do Paraná, onde foram encontrados efeitos semelhantes dos nutrientes sobre a clorofila, tendo sido verificado o mesmo padrão de distribuição.

A comunidade fitoplanctônica de um reservatório se mantém por meio da contínua entrada de nutrientes (vazões afluentes) e pelos nutrientes reciclados pelo zooplâncton e peixes. Uma maneira comumente utilizada para quantificar o volume de algas em um determinado reservatório é através da determinação das concentrações de clorofila- $a$ (STRASKABA \& TUNDISI, 2000).

A distribuição longitudinal da clorofila no reservatório foi constante para as zonas fluvial e lacustre, nas quais as concentrações médias encontradas foram semelhantes. Já a zona de transição, cujas maiores concentrações de clorofila foram associadas às maiores concentrações de nutrientes, apresentou uma distribuição relacionada com a sazonalidade da chuva. Os estudos de ANDRADE et al. (1988), corroboram com os resultados do presente estudo. As maiores concentrações de clorofila- $a$ no reservatório de Itaipu, na zona de transição, é explicada pelas maiores concentrações de nitrogênio total kjeldahl, P total e nitrato, e aparentemente estas corresponderam as formas de nutrientes que tiveram influência no aumento das concentrações de clorofilaa. PAGIORO et al.(2005b) comentam que a maior ocorrência das concentrações elevadas de clorofila-a nas zonas intermediárias (transição) são devidas a relação ideal entre luz e fósforo, mais encontrada nestas regiões, acrescendo a produtividade 
primária. Os autores salientam que este padrão na distribuição da clorofila nem sempre pode ser encontrado e isto ocorre porque outros fatores (tempo de residência, tamanho do reservatório, morfometria, etc.) têm influência sobre o metabolismo da produtividade primária.

Comparando os resultados aqui encontrados com o enquadramento da Resolução CONAMA 357/05, o reservatório de Itaipu pode ser enquadrado como Classe II, apesar das variáveis comparadas não chegarem a atingir os valores padrões estabelecidos pelo órgão responsável (Tabela 18), indicando que a qualidade das águas do reservatório está dentro de um padrão de qualidade considerado bom.

Tabela 18: Comparação entre os valores médios das zonas fluvial, transição e lacustre no reservatório de Itaipu com os valores propostos pela resolução CONAMA (357/05)

\begin{tabular}{lcccc}
\hline & CONAMA (357/05) & Zona fluvial & Zona de transição & Zona lacustre \\
\hline Sólidos dissolvidos & Até $500 \mathrm{mg} / \mathrm{L}$ & 10,9 & 6,4 & 3,4 \\
Turbidez & $100 \mathrm{NTU}$ & 20,3 & 23 & 9,2 \\
Oxigênio dissolvido & $\geq 5$ & 8,1 & 8,5 & 8,1 \\
pH & $6,0 \mathrm{a} 9,0$ & 7,5 & 7,8 & 7,6 \\
Fósforo total & até $0,025 \mathrm{mg} / \mathrm{L}$ & 0,003 & 0,003 & 0,002 \\
Nitrato & até $10 \mathrm{mg} / \mathrm{L}$ & 0,28 & 0,32 & 0,28 \\
Nitrito & até $1,0 \mathrm{mg} / \mathrm{L}$ & 0,005 & 0,006 & 0,005 \\
Nitrog. amoniacal & $2,0 \mathrm{mg} / \mathrm{L}$ & 0,04 & 0,03 & 0,03 \\
DBO & $5 \mathrm{mg} / \mathrm{L}$ & 1,8 & 2,7 & 2 \\
Clorofila & até $30 \mathrm{mg} / \mathrm{L}$ & 0,0038 & 0,0219 & 0,0047 \\
Cianobactérias & $20000 \mathrm{cel} / \mathrm{L}$ & 18941 & 2972 & 1400 \\
\hline
\end{tabular}

É importante salientar que o impacto da poluição difusa (atividades agrícolas) e da poluição pontual pode estar aumentando os níveis de nutrientes no reservatório de Itaipu, como é verificado na imagem de satélite da região onde está inserido o reservatório. (STIVARI et al., 2005). Um outro aspecto a ser analisado em relação à zona de transição é que, além da topografia mais acentuada, uma grande atividade de suinocultura é praticada nas microbacias do rio São Francisco Verdadeiro e Falso, tendo um efeito poluidor pelo aumento de nutrientes gerados pela falta de tratamento dos resíduos finais desta atividade (BENASSI, S.F., comunicação pessoal). Grande parte destas propriedades está localizada próxima às margens de afluentes do reservatório, explicando os aumentos das concentrações de nutrientes e, por seqüência, uma maior ocorrência de cianobactérias nesta região. 


\section{2. Índice de estado trófico (IET)}

O Índice de Estado Trófico tem por finalidade classificar os corpos aquáticos quanto ao enriquecimento de nutrientes e é obtido através de análises estatísticas de modelos de regressão linear (TOLEDO JR. et al., 1983). A transparência da água muitas vezes não apresenta valores que representem o grau de trofia do ambiente (TOLEDO JR. op. cit), principalmente para o valor limite de oligotrofia. Por este motivo, passou-se a utilizar a média ponderada dos índices calculados, atribuindo-se um menor peso ao índice de transparência da água (secchi), sem precisar retirá-lo do cálculo do IET médio.

Os resultados obtidos demonstram, de maneira bem clara, que a zona de transição apresenta um grau de trofia superior às demais, o que pode estar relacionado ao maior aporte de nutrientes (poluição difusa), como discutido anteriormente, ou pela relação da luz ideal com as concentrações de nutrientes.

Os valores médios de IET indicam uma pequena melhoria no estado trófico da água, seguindo um padrão espacial e temporal. Os valores encontrados para as zonas lacustre indicam que estas região é oligotrófica. Já as zonas fluvial e de transição, apresentaram valores mais elevados, chegando a concentrações que indicam um grau mesotrófico, com alguns valores eutróficos na zona de transição. Apesar disso, o valor médio encontrado para todo o reservatório, desconsiderando as divisões das zonas, indicou que suas águas podem ser classificadas como mesotrófica, corroborando com os estudos de ANDRADE et al. (1988). Esta mudança no estado trófico entre regiões diferentes também foram constatadas por ZANATA (1999) e MINILLO (2005), no qual a precipitação e a poluição difusa foram os fatores que melhor explicaram as mudanças no estado trófico.

Outro fator importante a ser considerado é o sistema de cascatas a montante do reservatório de Itaipu, presente nos rios Tietê, Grande e Paranapanema, que abastecem o rio Paraná, formador do reservatório. Este fator pode ter grande influência, pois as concentrações de nutrientes e material particulado sofrem um efeito redutor ao longo dos reservatórios em sistemas de cascatas (NOGUEIRA et al., 2005; ANDRADE et al., 1988). 


\subsection{Análise da distribuição longitudinal das comunidades biológicas (fitoplâncton, zooplâncton e peixes)}

As respostas das comunidades em reservatórios, em condições manipuladas ou não, são incompletas, sendo alteradas ou destruídas antes de sua completa interação. A instabilidade da formação de um novo ambiente torna as comunidades instáveis, por conta do represamento e ações antropogênicas (AGOSTINHO \& GOMES, 2005). O processo de sucessão espacial e temporal das comunidades em reservatórios depende da rapidez do enchimento, da retirada ou não da vegetação, do estabelecimento de uma extensa zona litoral que aumenta o substrato e dos processos de colonizações da bacia hidrográfica (TUNDISI, 1986a).

De acordo com TUNDISI (1990) o ciclo sazonal do fitoplâncton em reservatórios é devido, em grande parte, às alterações hidrodinâmicas. Os pulsos produzem no sistema súbitas mudanças, com rápidas descargas na superfície, tendo reflexos na entrada de material em suspensão, na disponibilidade de nutrientes e radiação solar (que acarreta mudanças na composição específica do fitoplâncton), bem como na freqüência de turbulência provocada pela ação dos ventos (que interfere na distribuição espacial, horizontal e vertical do fitoplâncton em reservatórios). Os autores salientam que o padrão de distribuição horizontal determina as distribuições características do fitoplâncton, ocasionando, em muitos casos, blooms de algas devido ao acúmulo produzido pelas correntes horizontais de superfície.

As relações entre a composição e a distribuição do fitoplâncton e os regimes físico-químicos são complexos e a interação só pode ser compreendida com estudos de longa duração (TUNDISI, 1990).

As variações das densidades e da composição das espécies (por grupo) apresentam um padrão de distribuição entre as zonas do reservatório, cuja dominância das cianobactérias (76\%, com máximo de 82384 org./ml) foi observada, sendo os outros grupos de algas poucos abundantes. Estes resultados corroboram os de PINTO COELHO et al. (2005), que obtiveram abundâncias de cianobactérias com valores de 11000 ind./ml, e de ANDRADE et al. (1988), no reservatório de Itaipu, com maiores densidades da cianobactéria Mycrocystis kutzing. As cianobactérias foram encontradas em densidades médias aceitáveis em todas as zonas, de acordo com a resolução CONAMA 357/05 (Tabela 17). Apenas na zona de transição foram registrados blooms das 
cianobactérias, fato que pode ser explicado pelo maior aporte de nutrientes em épocas de chuvas e pelos valores de $\mathrm{pH}$ (SHAPIRO \& WRIGHT, 1984). Um aspecto que deve ser considerado é o tipo de coleta dos dados, com amostras de águas retiradas apenas na superfície, região de maior desenvolvimento de cianobactérias (TUNDISI, 1990).

As baixas densidades dos grupos fitoplanctônicos estudados podem ser justificadas pelas baixas concentrações médias de nutrientes. Segundo REYNOLDS (1987), todas as espécies de fitoplâncton têm tendência a manter o crescimento enquanto houver disponibilidade de nutrientes, e as espécies com taxas de crescimento mais rápidas são selecionadas em ambientes com condições nutricionais favoráveis.

Os resultados das análises de covariância indicam que a variável independente TKN apresentou efeito positivo no desenvolvimento de cianobactéria no reservatório de Itaipu, além do efeito da variável categórica zona do reservatório (diferença entre as zonas fluvial e lacustre). O modelo gerado pode estimar as biomassas de cianobactérias a partir das variável independentes acima citada.

Quando as cianobactérias foram relacionadas com os nutrientes e a guilda de peixes onívoro, os resultados indicaram que as variáveis explanatórias que melhor explicaram o modelo foram os onívoros e avariável categórica zona do reservatório.

O segundo grupo mais abundante foi o das clorofíceas, apesar dos valores de abundância relativa indicarem que as diatomáceas apresentaram densidades relativas um pouco maiores, sendo explicadas pela ocorrência de um aumento registrado em março de 2004, quando foi contabilizada uma densidade de 1001 org/l na amostra analisada. Assim, apesar das diatomáceas não terem sido responsáveis pelo maior valor médio de densidade, a abundância relativa foi a segunda mais elevada nesta zona, porque as amostras mensais responderam pelos maiores valores obtidos.

A proporção entre os diferentes grupos que compõem a comunidade zooplanctônica (rotíferos, copépodos e cladóceros) é considerada uma forma de utilização desta comunidade como indicadora das condições tróficas do ambiente, sendo a dominância de rotíferos freqüentemente associada ao aumento da eutrofização (MATSMURA-TUNDISI et al., 1990).

No reservatório de Itaipu o grupo com maior dominância foi o do Copepoda, com as maiores densidades em todo o sistema (57,97\%). Estudos em reservatórios do Paraná indicam a mesma dominância do copépodos (VELHO et al., 2005) e no reservatório de Tucuruí, ESPÍNDOLA et al (2000) observaram o mesmo padrão. A maior densidade de Copepoda, bem como de Cladocera, pode estar associada a um 
maior grau de trofia nas zonas onde as concentrações de clorofila e cianobactérias foram maiores. De acordo com MARZOLF (1990), maiores densidades de zooplâncton na zona de transição são observadas quando a disponibilidade de recurso e a hidrodinâmica estiverem interagindo na determinação de seus padrões de abundância.

As maiores abundâncias de zooplâncton foram registradas na zona de transição do reservatório de Itaipu. Estudos realizados por LANSAC-TÔHA et al. (1999) em reservatórios paranaenses demonstraram resultados que corroboram os deste trabalho. A maior abundância na zona de transição é explicada pelas maiores concentrações de clorofila, devido à maior ação antrópica observada nas bacias dos rios São Francisco Verdadeiro e Falso, localizados na zona de transição. A distribuição de pequenos cladóceros pode ser relacionada com as abundâncias de cianobactérias, principalmente em ambientes eutróficos (LANSAC-TÔHA et al., 2005). As propriedades bioquímicas das cianobactérias (podendo algumas espécies apresentar toxicidade) e a forma e tamanho das colônias impedem que haja uma super exploração deste recurso por parte do zooplâncton, mantendo as abundâncias das colônias estáveis (DE BERNADI \& GIUSSANI, 1999).

O segundo grupo mais abundante foi o dos rotíferos. Embora os ambientes eutróficos e hipereutróficos favoreçam a dominância de rotíferos, na maioria dos ambientes aquáticos do Brasil os rotíferos são freqüentemente dominantes, independentemente do estado trófico, tanto em densidade como em número de espécies (ROCHA et al., 1995). A não dominância numérica dos rotíferos no reservatório de Itaipu (32\%) condiz com os resultados para lagos oligotróficos e mesotróficos dos Estados Unidos (BLANCHER, 1984), no qual os rotíferos representam de 20 a 37\%.

Em relação à distribuição do eixo longitudinal do reservatório, a maior densidade de rotíferos foi encontrada na zona fluvial e nas demais zonas verificou-se a dominância de copépodos. Estudos no reservatório do rio Corumbá (LANSAC- TÔHA, 1999), demonstram que a estrutura da comunidade foi alterada após o barramento, quando as densidades de cladóceros e copépodos apresentaram um maior desenvolvimento. Outros autores relacionam o grau de trofia com a estrutura da comunidade do zooplâncton (MATSMURA-TUNDISI et al., 1990; LANSAC-TÔHA et al., 2005).

O estudo da determinação da variação espaço-temporal das comunidades de peixes e a forma em que estes estoques são retirados do ambiente são utilizados para a racionalização do manejo pesqueiro (OKADA, 2001). De acordo com HODGSON et al. 
(1996) as populações de peixes exercem efeitos de fundamental importância nas cascatas tróficas, tendo influência direta na biomassa e produtividade de outros níveis tróficos.

Os resultados da variação da estrutura trófica dos peixes mostram que o grupo dos onívoros foi o mais abundante no reservatório $(2068048,9 \mathrm{~kg}$ ), seguido pelos píscívoros. Estes dois grupos foram responsáveis por $77,7 \%$ da biomassa total, correspondendo a $3374239 \mathrm{~kg}$ de peixe. A zona fluvial apresentou uma maior ocorrência de onívoros e detritívoros. Nas zonas de transição e lacustre os onívoros e piscívoros foram mais abundantes. BORGHETTI et al. (1988) também encontraram oito grupos tróficos no reservatório de Itaipu no período de 1983 a 1986, sendo que os piscívoros foram dominantes $(25,6 \%)$, seguidos pelos iliófagos $(15,6 \%)$, onívoros $(12,5 \%)$, insetívoros $(9,4 \%)$, herbívoras $(3,4 \%)$, planctívoros $(1,6 \%)$ lepidófagosinsetívoros $(1,6 \%)$ e outros $(9,4 \%)$. AGOSTINHO et al. (1999), em um estudo de seis anos (1983 a 1989) no reservatório de Itaipu, encontraram resultados semelhantes, com maiores ocorrências de onívoros e piscívoros. OLIVEIRA et al. (2005) encontraram maiores biomassas de pescada (piscívoros), detritívoros e onívoros no reservatório de Itaipu. As diferenças entre as guildas tróficas de peixes do presente estudo para o de OLIVEIRA et al (2005), podem ser explicadas pelas diferenças na metodologia de coleta, pois estes autores utilizaram apenas redes de espera em seus estudos. Os resultados aqui apresentados são provenientes de desembarques da pesca profissional, na qual as biomassas pesqueiras são mais bem representadas pelo fato de os pescadores exercerem esta atividade com maior assiduidade. $\mathrm{O}$ acompanhamento das atividades da pesca profissional no reservatório começou em 1985, persistindo até o presente, sendo de grande importância para o conhecimento do funcionamento da dinâmica dos peixes. Os petrechos de pescas mais utilizados pelos pescadores profissionais no reservatório são: redes de espera (86\% dos pescadores), espinheis (37\%), anzóis de espera (18,9\%), linhadas $(18,7 \%)$, caniços $(6,8 \%)$ e tarrafas $(5,1 \%)$, além de fisgas, covos e anzóis de galho (AGOSTINHO \& GOMES, 2005).

AGOSTINHO et al. (1997a) caracterizaram a estrutura das guildas tróficas dos peixes do rio Paraná, na qual os piscívoros foram mais abundantes e diversos. Os autores salientam que a dinâmica do ambiente está relacionada à diversidade de espécies nas categorias tróficas, sendo evidenciada pela estrutura da diversidade do seu componente abiótico e pelas inter-relações bióticas regidas pelo ciclo hidrológico. 
Sendo o reservatório de Itaipu um barramento artificial do rio Paraná, é de se esperar que a estrutura da comunidade de peixes tenha forte influência do regime hidrológico deste rio. No estudo anterior citado acima foram encontradas as maiores abundâncias de piscívoros e iliófagos, no qual ambas foram favorecidas pelo efeito do pulso de inundação, desenvolvendo áreas ideais para o favorecimento do aumento destes estoques (reprodução e alimentação). Este efeito pode explicar as grandes biomassas de onívoros e píscívoros registradas neste trabalho, no qual a zona fluvial e de transição apresentaram grandes biomassas de onívoro, e os piscívoros foram mais dominantes na zona lacustre.

\subsection{Relações tróficas (top-down e bottom-up) no reservatório de Itaipu: efeitos diretos e indiretos}

A teoria de cascata trófica em lagos e reservatórios é baseada no fato de cada nível trófico da cadeia alimentar ser inversamente e diretamente relacionado com os níveis tróficos abaixo ou acima, seguindo dois princípios: a perda de energia entre um nível trófico e outro superior; e a perturbação de um nível trófico acarretando conseqüências nos demais níveis tróficos. Os estudos que testaram e comprovaram esta hipótese em lagos e reservatórios temperados são inúmeros (HRBÁČEK et al., 1961; SHAPIRO et al., 1975; SHAPIRO \& WRIGHT, 1984; CARPENTER et al., 1985; PERSSON et al., 1988; CARPENTER \& KITCHELL, 1988; MCQUEEN, 1990; POWER, 1990; BRETT \& GOLDMAN, 1996; BRETT \& GOLDMAN, 1997; HAIRSTON \& HAIRSTON, 1997; MEIJER et al., 1999; JEPPESEN et al., 2000; GULATI, 2001; CARPENTER et al., 2001; BENNDORF et al., 2002; LATHROP et al., 2002; BELL et al., 2003; HANSSON et al., 2004; BORER et al., 2005; MEHNER et al., 2005), ao contrário do que acontece em lagos tropicais, onde estudos de cascatas tróficas são escassos (QUIRÓS \& BOVERI, 1999; SCASSO et al., 2001; HASAN et al., 2001; LAZZARO et al., 2003; REJAS et al., 2005; JEPPESEN et al., 2005).

Os efeitos top-down em ambientes temperados são explicados por MCQUENN (1990) e LAZZARO (1997), nos quais as relações entre os níveis tróficos sofrem efeito negativo da piscivoria para os demais níveis abaixo (Figura 67). 


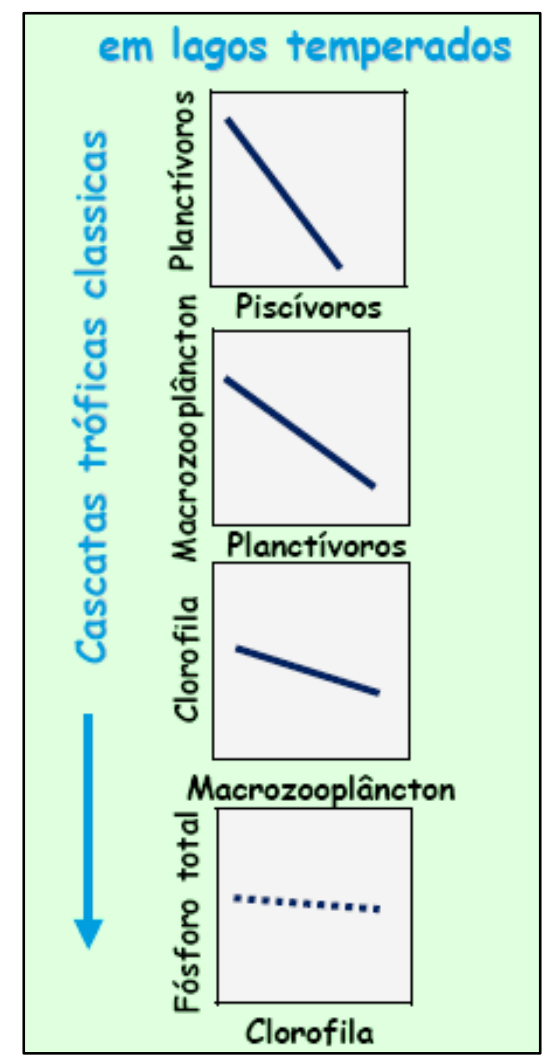

Figura 67: Efeito negativo da cascata trófica em ambientes temperados (Fonte: LAZZARO, 2002).

LAZZARO et al. (2003) investigaram os efeitos de cascatas tróficas em açudes de Pernambuco. As relações que são bem explicadas em lagos e reservatório temperados não se mostraram tão evidentes em ambientes tropicais (Figura 68). Os autores sugerem que o estado das guildas tróficas de peixes é que desempenha o principal papel nas cadeias alimentares em reservatórios do Nordeste do Brasil, onde efeitos indiretos entre a concentração de clorofila e as densidades de peixes onívoros apresentam relação positiva, indicando que os onívoros, de alguma forma, exercem uma pressão para o desenvolvimento da clorofila. De acordo com JEPPESEN et al. (2005), isto ocorre por que a riqueza de espécies de peixes é freqüentemente mais alta em lagos tropicais e subtropicais. A América do Sul e África têm uma fauna de peixe de água doce muito rica e muitas das espécies de peixe mostram uma sobreposição parcial de nicho, aumentando o controle das presas (LAZZARO, 1997). Este efeito também foi observado por STEIN et al. (1995) em lagos no sul dos Estados Unidos.

As comunidades de peixes de lagos tropicais e subtropicais são dominadas freqüentemente por espécies onívoras, que apresentam grande plasticidade alimentar, consumindo zooplâncton, fitoplâncton, perifíton, macroinvertebrados bentônicos e 
detritos. De acordo com LAZZARO et al. (2003), os piscívoros são representados por poucas espécies e apresentam-se em pequenas biomassas, e uma maior biomassa de pequenos carnívoros e onívoros geralmente rege a dinâmica da cadeia trófica.

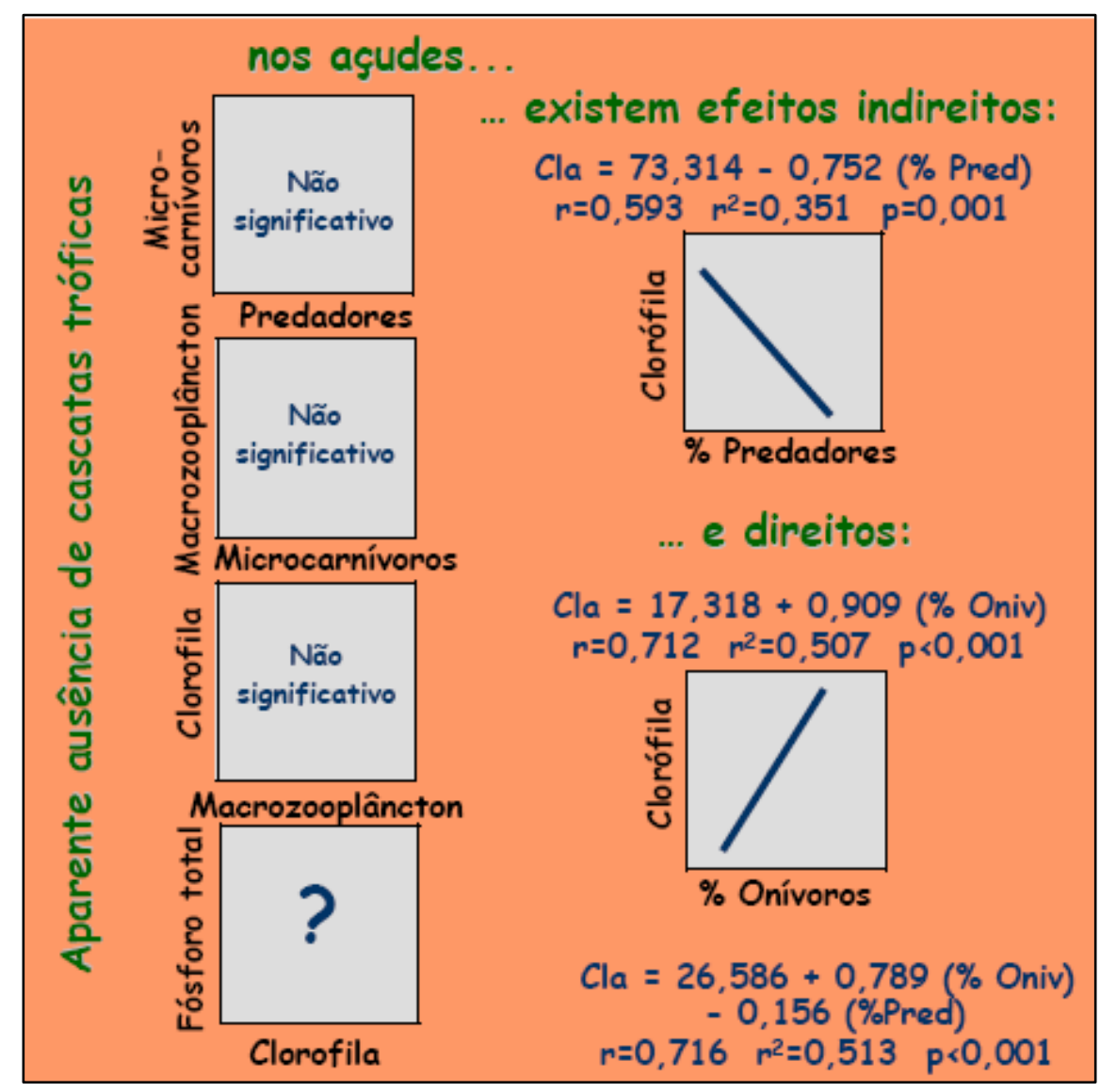

Figura 68: Ausência de relações diretas na cascata trófica em ambientes tropicais (Fonte: LAZZARO, 2002).

Algumas espécies de onívoros não são controladas pela disponibilidade de recurso alimentar (zooplâncton) e nem através da pressão da predação por serem maiores que seus predadores potenciais (ARCIFA et al., 1995). O controle top-down através de peixes piscívoros é, portanto, mais fraco em lagos subtropicais/ tropicais do que em lagos temperados.

ROCHE \& ROCHA (2005) discutiram o efeito da planctivoria em lagos e reservatórios no Brasil, salientando os efeitos da predação, tipos de alimentação e seletividade alimentar, efeitos de larvas e alevinos, disponibilização de nutrientes, grau de trofia do ambiente e hidrologia.

LAZZARO (1987) salienta que em grande parte dos estudos já realizados envolvendo o impacto de peixes planctívoros, não foi determinado o comportamento alimentar das espécies estudadas e, por conseqüência, os mecanismos que determinam a 
seletividade alimentar dos peixes e a utilização de seus recursos não são bem entendidos. $\mathrm{O}$ autor explica que os peixes têm uma alta capacidade de mudança no padrão de seletividade alimentar, classificando os peixes de acordo com o modo de alimentação: visual particulada, filtração por bombeamento e filtração por arrasto. No caso das duas primeiras, vários fatores influenciam no sucesso da predação, como o tamanho das presas e a intensidade luz, e espécies jovens de peixes que se alimentam pelo modo visual particulado podem mudar para o modo de alimentação por filtração por bombeamento quando se tornam adultos. LAZZARO (1991) demonstrou este efeito em experimentos em laboratório com a espécie de ciclídeo Geophagus brasiliensis (cará). ROCHE et al. (2005) testaram a seletividade alimentar para a mesma espécie em experimentos em mesecosmos in situ no reservatório do Lobo-Broa (SP). Os autores verificaram que a biomassa de Daphnia sp diminuia nos tratamentos com peixes, comprovando a pressão por seletividade alimentar, corroborando os estudos em laboratório de LAZZARO (1991).

A predação tem um importante efeito na medida em que controla o excesso de presas disponíveis, permitindo que haja maior sobrevivência daquelas remanescentes em função da oferta de alimento limitada, especialmente quando a taxa de reprodução da presa é muito alta, como no caso da tilápia (ODUM, 1983).

Em sistemas onde ocorrem altas densidades de peixes, pode haver perda de peso e morte dos indivíduos (MCQUEEN, 1990). A presença do predador oferece uma estabilidade ao sistema, uma vez que, havendo predação, ocorre diminuição do estoque de presas, evitando assim a ausência e disputa de alimentos pelos forrageiros. PAIVA et al. (1994) realizaram estudo onde o número de espécies de predadores interferiu na dinâmica trófica em reservatórios do Nordeste do Brasil. Eles observaram que nos reservatórios em que havia duas espécies de predadores a captura de pescado era alta, e em reservatórios com menos de duas espécies de predadores a competição entre as presas provavelmente contribuía para a diminuição da captura.

Vários autores sugerem que a estrutura e biomassa de comunidades de água doce sejam reguladas por predadores (HRBÁČEK et al., 1961; SHAPIRO et al., 1975; SHAPIRO \& WRIGHT, 1984; CARPENTER et al., 1985; PERSSON et al., 1988). Pode-se dizer que o aumento da biomassa de piscívoros está associado à redução da biomassa de planctívoros, ao aumento da biomassa do zooplâncton grande e à redução do fitoplâncton (CARPENTER et al., 1985; MCQUEEN, 1990; MEIJER, 1999; GULATI, 2001). As interações assumidas pela predação podem promover a redução da 
biomassa de planctívoros e estas, associadas ao aumento da biomassa de zooplâncton grande e ao aumento da razão de consumidores de algas (grazing), reduzem a biomassa de fitoplâncton. Vários autores (SHAPIRO \& WRIGHT, 1984; VANNI \& FINDLAY, 1990) têm notado que os predadores são importantes para a mudança do zooplâncton.

De acordo com a hipótese de cascata trófica, o aumento da biomassa de peixes piscívoros (carnívoros) em um lago ou reservatório faz com que a biomassa de peixes planctívoros diminua, aumentando a biomassa de zooplâncton e reduzindo a biomassa fitoplanctônica (SHAPIRO et al., 1975, CARPENTER et al., 1985).

LAZZARO et al. (2003) ressaltam que efeitos Top-down em ambientes tropicais são mais complexos do que em temperados, não existindo espécies essencialmente zooplanctívoras e sim onívoras (como é o caso da tilápia), e os píscívoros dão lugar a macrocarnívoros generalistas. A concentração de clorofila aumenta com a biomassa de peixe onívoro e decresce com a biomassa de macrocarnívoro. Contudo, nesse trabalho, a concentração de clorofila não teve relação com a biomassa global de peixe e a biomassa de macrozooplâncton. As interações entre peixe e a concentração de clorofila e entre peixe e a biomassa de zoplâncton foram inversamente relacionadas ao estado trófico. A regulação peixe-fitoplâncton originada pela complexidade das interações da onivoria está presente no comportamento alimentar de várias populações de consumidores.

Os resultados mostram que o reservatório de Itaipu apresentou relações topdown e bottom-up, corroborando o trabalho de REJAS et al. (2005) em experimentos em um lago boliviano, com efeitos diretos e indiretos na cascata trófica (Figura 68). O efeito top-down foi encontrado apenas no primeiro nível trófico, e as biomassas de piscívoros exerceram um controle sobre os onívoros e detritívoros, e não apresentaram efeito predatório nas biomassas de bentívoros e zooplânctívoros, cujas biomassas aumentaram. Isto sugere que os piscívoros podem ter um efeito na qualidade da água no reservatório, não positivamente e sim negativamente, uma vez que as relações indiretas entre as guildas predadas pelos predadores mostraram ter um efeito controlador, tanto da clorofila como das cianobactérias. $\mathrm{O}$ efeito controlador dos piscívoros também foi relatado por PELICICI et al. (2005) em 31 reservatórios do estado do Paraná.

O efeito dos peixes onívoros sobre os demais grupos tróficos de peixes também foi avaliado, uma vez que este grupo é constituído em grande parte por peixes de grande porte (mandi e armado, por exemplo). Esta análise indica que o aumento da biomassa de 
onívoros ocasionou depleção da biomassa de bentívoros e detritívoros, ao contrário do que ocorreu com os zooplânctívoros, que tiveram sua biomassa aumentada.

Uma importante relação estudada foi entre os detritívoros e a produção primária no reservatório. Apesar dos resultados indicarem que este grupo sofre uma forte pressão por predação dos piscívoros e onívoros, os detritívoros demonstram controle sobre a clorofila e cianobactérias.

Quando os filtradores onívoros dominam os peixes planctívoros, a hipótese "peixe versus estado trófico do lago" pode não ser mais válida porque a estimulação do crescimento pelos peixes onívoros é intensificada pelo aumento da carga em nutrientes (DRENNER et al., 1996). Os sistemas dominados pela onivoria apresentam ligações tróficas fracas, devido a uma combinação de mecanismos amortizados. Por conseqüência, eles são dificilmente previsíveis a partir da hipótese das cascatas tróficas. Entre os mecanismos envolvidos, LAZZARO et al. (2003) comentam a "predação intraguilda" (IGP), que se aplica aos peixes onívoros que se alimentam de zooplâncton herbívoro e do seu alimento fitoplanctônico e à onivoria ontogenética (mesmo mecanismo que ocorre durante a ontogenia do peixe, da fase juvenil à adulta).

A ausência do efeito da predação dos zooplânctívovros, demonstrada na análise estatística, também indica prejuízos na qualidade da água, com efeito positivo relacionado com as cianobactérias. Estudos realizados por ABUJANRA \& AGOSTINHO (2002) ressaltam a grande adaptabilidade que espécies de zooplanctívoros apresentam em seu sistema de branquiais, sendo essas grandes, longas, finas e numerosas, e que o mecanismo de filtração do mapará é de deslocamento com filtração passiva, consistindo de natação com a boca aberta com os opérculos dilatados, com uma dieta alimentar composta basicamente de zooplâncton. Estes resultados evidenciam a importância das cadeias de onivoria e detritivoria nos ambientes aquáticos tropicais e subtropicais. Estes resultados corroboram os trabalhos de LAZZARO (1997) e LAZARRO et al. (2003), que enfatizam o efeito de onívoros e da cadeia detritívora nestes ambientes. 


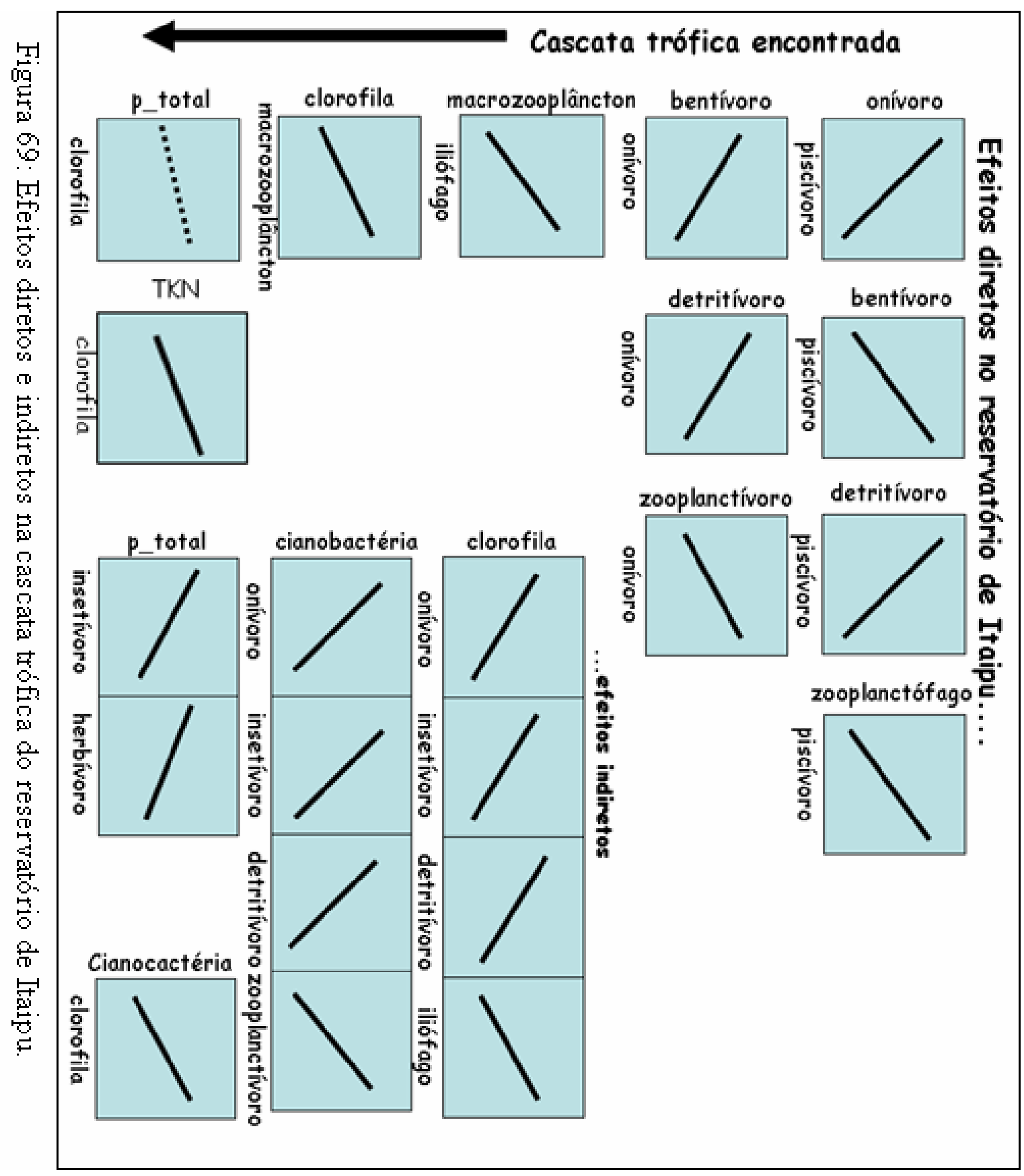


A única guilda de peixes que apresentou relação com o macrozoplâncton foi a composta pelos iliófagos, sendo que as relações foram positivas e não negativas como acontecem em ecossistemas temperados (MCQUEEN et al., 1990; CARPENTER \& KITCHELL 1993). Estes resultados sugerem que o aumento das biomassas de iliófagos acarreta em um aumento nas comunidades do zooplâncton herbívoro, indicando que a pressão dos peixes não afeta a comunidade de zooplâncton, que é capaz de consumir o fitoplâncton, aparentando ser um efeito bottom-up.

A baixa pressão que os peixes causam no zooplâncton implica na dominância de indivíduos de pequeno porte nas comunidades de zooplâncton em lagos tropicais e subtropicais (LAZZARO, 1997). Os copépodos onívoros normalmente dominam em termos de biomassa em sistemas oligomesotróficos, considerando que o microzooplâncton prevalece em sistemas mais eutróficos. Em altas temperaturas, as flutuações diárias das condições físicas e químicas ou mudanças ambientais súbitas (devido a chuvas pesadas, por exemplo) podem alterar a comunidade zooplanctônica (aumentando o número de protozoários e rotíferos), que tem a capacidade de recuperação muito rápida. $\mathrm{O}$ controle clássico de fitoplânctom pelo macrozooplâncton em lagos temperados não é tão freqüentemente evidenciado em lagos tropicais (LAZZARO, 1997; JEPPSEN et al., 2005; REJAS et al., 2005). Esta ausência de pressão da predação no zooplâncton pode representar uma limitação adicional na dificuldade da biomanipulação em lagos tropicais e subtropicais.

BACA \& DRENNER (1995), em estudo em mesocosmos, verificaram que o predador causa um forte impacto sobre a comunidade de planctívoros, mas as interações dos níveis tróficos abaixo destas comunidades não apresentaram um forte efeito sobre a comunidade zooplanctônica e fitoplanctônica. Os resultados acima descritos podem explicar o fato de a comunidade zooplanctônica, em relação às análises do macrozooplâncton (cladóceros e copépodos), ter aumentado sua biomassa no presente estudo. Os resultados mostram que não existe pressão por predação dos peixes sobre o zooplâncton. Estudos em 31 reservatórios do estado do Paraná demonstram a mesma relação positiva entre o macrozooplâncton e a clorofila. De acordo com LAZZARO (1997), em ambientes tropicais as presas não são estritamente zooplanctívoras e sim onívoras, não tendo efeito direto na comunidade zooplanctônica.

O macrozooplâncton (cladóceros e copépodos) apresentou relação positiva com a clorofila, indicando não ter havido controle do mesmo na clorofila. Estes resultados corroboram os trabalhos de LANSAC-TÔHA et al. (2005) e PIANA et al. (2005), 
realizados em reservatórios do Paraná, nos quais também foram encontradas relações positivas entre o zooplâncton e a clorofila. Este tipo de relação é inverso ao que é comumente encontrado em lagos e represas temperados (MCQUEEN, 1990, CARPENTER \& KITCHELL, 1993), indicando um efeito bottom-up.

O último nível trófico analisado, comprovando o efeito bottom-up, foi a interação clorofila-nutriente, onde o aumento das concentrações de clorofila se relacionou positivamente com as concentrações de fósforo total. Em ambientes temperados esta relação é positiva (MCQUEEN, 1990; CARPENTER \& KITCHELL, 1993), verificando-se que as concentrações de nutrientes controlam as de clorofila.

HAMBRIGHT et al. (1991) salientam que um fator complicador para o funcionamento da hipótese de cascata trófica é a suposição de que todas as populações de peixes planctívoros são suscetíveis ao aumento da biomassa de piscívoros. HAMBRIGHT (1994) também mostra que as características morfológicas (como abertura bucal dos predadores) e o ambiente de refúgio das presas são fatores de extrema importância para o desenvolvimento da hipótese de cascata trófica.

As relações indiretas indicam um controle de clorofila e cianobactérias pelos onívoros, insetívoros e detritívoros. Estes três grupos de peixes podem ser utilizados no controle da qualidade da água no reservatório, onde experimentos em laboratório e in situ (mesocosmos) podem fornecer respostas para o manejo deste ambiente. Os iliófagos e os zooplânctívoros apresentaram relação positiva com a clorofila e cianobactérias, respectivamente. Estes resultados indicam que ambos os grupos de peixes, de alguma maneira, impulsionaram o desenvolvimento da produtividade primária. Medidas como o incremento destas espécies nas pescarias, tanto artesanais como esportiva, trariam resultados benéficos no controle da qualidade da água no reservatório.

Os únicos grupos de peixes que apresentaram relação com a concentração de fósforo total foram os insetívoros e herbívoros. Ambos apresentaram relações negativas com o fósforo, indicando que o aumento da biomassa destes acarreta uma diminuição das concentrações de fósforo total. Estes resultados indicam que medidas de manejo destas espécies (aumento do estoque) podem apresentar um maior controle de fósforo total no reservatório.

PERSSON (1997) comparou a taxa de excreção de fósforo para peixes zooplanctívoros, com estimativas de cargas internas e externas em um lago eutrofizado (Lago Finjasjon, Suécia). Os experimentos foram realizados em laboratório, utilizando duas espécies de presas (uma bentônica e outra pelágica), e os resultados foram 
extrapolados para todo o lago, usando o cálculo do consumo de presas pelo peixe, baseado em dados de campo sobre a estrutura da comunidade, crescimento da taxa de excreção e dieta do peixe. A taxa de fósforo excretada pelo peixe foi em média de $0,53 \mathrm{mg} \mathrm{P} / \mathrm{m}^{2} / \mathrm{d}$, a qual teve um aumento de $110 \%$ de carga externa e $42 \%$ de carga interna. A maior parte do fósforo lançado pelo peixe é reciclada dentro da coluna da água, isto é, mais de $18 \%$ do fósforo lançado na água provém do alimento bentônico, representando, assim, o transporte de fósforo do sedimento para a coluna da água. $\mathrm{O}$ fósforo excretado pelo peixe tornou-se disponível para o fitoplâncton, sugerindo que o nutriente talvez constitua uma fonte importante para as algas.

Os peixes liberam fósforo na água diretamente através de processos metabólicos (excreção) e, indiretamente, devido a seu hábito de revolver o sedimento em busca de alimento, disponibilizando o nutriente para a coluna da água (PERSSON, 1997; PEREIRA \& RIBEIRO FILHO, 2004). STARLING (1998) ressalta que a importância dos peixes na manutenção das concentrações de fósforo na água pode ser maior que a de fontes alóctones, principalmente como fonte de nutriente na região pelágica. BRABRAND et al. (1990) salientam que o fósforo solúvel é a principal forma de fósforo excretada pelos peixes, e STARLING (1998) demonstrou que a tilápia é o peixe que apresenta a maior taxa de excreção de fósforo solúvel no Lago Paranoá.

Ao analisar as relações diretas de um nível trófico para outro, observou-se que o reservatório de Itaipu apresenta uma forte evidência de força bottom-up, cujos efeitos positivos foram encontrados em grade parte. Somente as análises do efeito da predação dos peixes sobre peixes apresentaram relações negativas, indicando um efeito top-down. Estes resultados sugerem que o reservatório de Itaipu apresenta os dois tipos de efeitos, sendo que o efeito bottom-up foi observado em três níveis tróficos, enquanto top-down apresentou efeito em apenas um nível. A teia trófica está representada na Figura 70 e evidencia os efeitos diretos e indiretos de top-down e bottom-up no reservatório de Itaipu. 


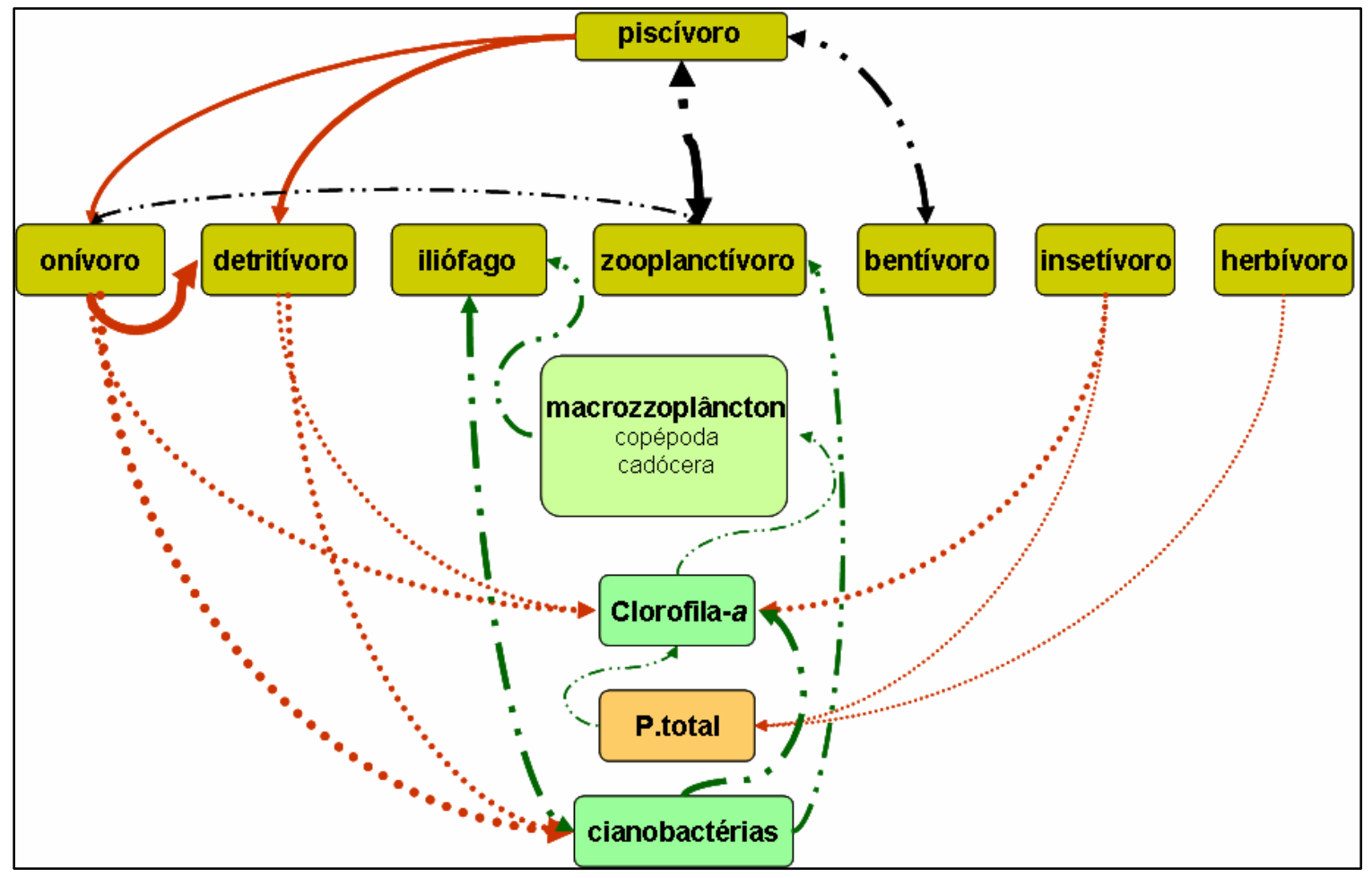

Figura 70: Rede trófica do reservatório de Itaipu. As setas direcionadas para baixo e em cor vermelha indicam um efeito top-down, as setas com ponto e risco e em cor verde indicam um efeito bottom-up, as setas pontilhadas indicam um efeito indireto, as espessuras das setas indicam o coeficiente de correlação destas relações e as cores indicam os diferentes níveis tróficos (peixes, zooplâncton, fitoplâncton e nutrientes).

É importante ressaltar que o reservatório de Itaipu, localizado em região subtropical, recebe grandes afluentes (rios Paranapanema, Tiete e Grande) oriundos do estado de São Paulo e estão localizados na região tropical. Será que o reservatório de Itaipu pode apresentar uma forte influência de sistemas tropicais? Será que o sistema de reservatórios em cascata a montante do reservatório de Itaipu tem influência na dinâmica da cadeia alimentar? Estudos com esta mesma abordagem, incluindo outras variáveis, como as biomassas de macrófitas e aves predadoras e macroinvertebrados bentônicos, podem ajudar a elucidar esta questão.

Segundo STRAŠKRABA \& TUNDISI (2000), a rede alimentar de um reservatório é representada por diversos grupos de organismos, de acordo com seus modos de vida e hábitos alimentares. Os grupos de organismos estão mutuamente relacionados principalmente pelos seus hábitos alimentares, pelas reações alelopáticas, pelas reações comportamentais e pela reciclagem de nutrientes. Os autores ressaltam a importância do conhecimento dos organismos aquáticos e da cadeia alimentar de um reservatório, cuja presença e ausência de determinadas espécies e sua cadeia alimentar serve como indicador a longo prazo da qualidade da água. 


\subsection{Inferência da produção pesqueira}

Os modelos preditivos para estimar a produção e a produtividade pesqueira são comumente utilizados em lagos e reservatórios Africanos e Norte Americanos (HENDERSON \& WELCOMME, 1974; MELACK, 1976; OGLESBY, 1977; SCHLEISINGER \& REGIER, 1982; MARSHALL, 1984; SASS \& KITCHELL, 2005).

Inúmeras variáveis independentes podem ser utilizadas para predição de índices que explicam a produtividade pesqueira em lagos e reservatórios, através de variáveis bióticas e abióticas (área do reservatório; profundidade média, alcalinidade, temperatura do ar, transparência da água, sólidos dissolvidos, índice morfoedáficoMEI, biomassa de clorofila e fitoplâncton, produção primária, bentos, macrófitas, biomassa de peixes), que podem ser testadas em modelos univariados ou multivariados.

De acordo com os resultados encontrados, o modelo prediz que o aumento das concentrações de cianobactérias implica em depleção na captura de peixes no reservatório de Itaipu. O coeficiente de correlação explicou 49\% $(\mathrm{p}=0,05)$. PIANA et. al. (2005), em um estudo em 29 reservatórios do Paraná, desenvolveu um modelo multivariado, cuja biomassa de peixes foi explicada pelas variáveis clorofila e zooplâncton. Os autores salientam que o efeito bottom-up nestes ambientes é explicado pela relação positiva com a clorofila e negativa com o zooplâncton.

A inferência da produtividade pesqueira pela equação de MELACK (1974) foi de $8,1 \mathrm{~kg} / \mathrm{ha} /$ ano e este resultado é semelhante ao obtido por AGOSTINHO \& GOMES (2005), que encontraram um valor médio de $7,9 \mathrm{~kg} / \mathrm{ha} /$ ano médio para os anos de $2000 \mathrm{a}$ 2004, indicando que uma análise para a formulação do próprio modelo do reservatório pode revelar predições precisas.

É importante salientar que estes modelos apresentam uma estimativa rápida, porém estudos do acompanhamento da pesca profissional e amadora durante um longo período de tempo (como realizados pela Itaipu) são de extrema importância para o conhecimento da produtividade pesqueira, bem como da dinâmica da estrutura das espécies de peixes do reservatório.

A relação entre o MEI e a transparência da água foi verificada através de análise de regressão. Esta relação indica que a diminuição da transparência da água influencia na depleção do MEI $\left(\mathrm{r}^{2}=0.684, \mathrm{p}=<0.001\right)$ e a relação entre a clorofila e o MEI é inversa à da transparência da água $\left(\mathrm{r}^{2}=0,350, \mathrm{p}=0,00297\right)$, indicando que o 
aumento da concentração de clorofila influência positivamente no MEI. Este mesmo comportamento das relações também foi observado em reservatórios Indianos (HASAN et al., 2001), nos quais a transparência da água teve efeito negativo e a clorofila, positivo. Estas relações indicam que a análise entre o MEI e uma série de dados da produção pesqueira pode gerar um modelo preditivo da produtividade pesqueira no reservatório. Uma análise utilizando o índice morfoedáfico e as capturas podem revelar um modelo mais preciso da produtividade pesqueira. De acordo com MAROUELLI et al. (1988), a estimativa da abundância e produção pesqueira se faz necessária como ferramenta para a resolução de problemas relacionados ao manejo pesqueiro em reservatórios.

Outro aspecto a ser considerado é que todas as análises das variáveis da qualidade da água foram realizadas com dados de coleta da superfície da água. Isto pode explicar porque o modelo gerado que mostrou melhor ajuste com as capturas foi aquele que incluiu os dados de cianobactérias. Este grupo de algas é dominante nas regiões superficiais de lagos e reservatórios, sendo a ação dos ventos um fator determinante para o aparecimento de blooms (TUNDISI, 1990).

A falta de informações detalhadas acerca da produção de peixes impossibilitou a geração de modelos com poder de predição mais eficiente. Esta linha de pesquisa é de grande valia, e bons modelos que inferem a produção e produtividade pesqueira em lagos e reservatórios constituem uma ferramenta que pode ser utilizada pelos órgãos responsáveis pelo gerenciamento dos recursos aquícolas no Brasil. 


\section{CONCLUSÕES}

$\checkmark$ A hipótese de cascata trófica no reservatório de Itaipu apresentou os dois efeitos top-down e bottom-up, sendo que o efeito negativo dos piscívoros foi observado apenas no nível trófico abaixo, e o efeito dos demais níveis foram positivos, caracterizando uma força mais forte de bottom-up;

$\checkmark$ O ciclo da cadeia trófica parece ser explicado pelas biomassas de onívoros e detritívoros, efeito este observado em ambientes tropicais e subtropicais, sendo de extrema importância nas relações (indiretas), determinando as forças de controle da produtividade primária no reservatório.

As variáveis limnológicas no reservatório de Itaipu apresentaram um padrão de variação espacial (horizontal) e temporal fortemente dependente do regime hidrológico.

As formas de nutrientes que influenciaram o desenvolvimento da produtividade primária (expressa pela clorofila- $a$ ) foram o TKN e o nitrogênio amoniacal, sendo que o TKN apresentou efeito positivo, e o nitrogênio amoniacal um efeito negativo. Os modelos gerados respondem como estas variáveis influenciam na concentração da clorofila.

$\checkmark$ Os efeitos negativos da turbidez e sólidos suspensos sobre a transparência da água foram comprovados por meio das análises de regressão múltipla, sendo que o modelo gerado explica em torno $66 \%$ deste efeito.

A zona de transição foi a que apresentou as maiores concentrações de nutrientes, maior concentração de clorofila, maior densidade de cianobactérias e de zooplâncton 
e um maior grau de trofia, caracterizando condições eutróficas, mais, em média, foi considerada mesotrófica.

$\checkmark$ Os resultados médios dos Índices de Estado Trófico indicam um estado de mesotrofia para todo o reservatório e para as zonas fluvial e transição separadamente; a zona lacustre se mostrou oligotrófica. Verifica-se, no decorrer de anos de estudo, que o processo de eutrofização do reservatório vem ocorrendo de maneira lenta, porém, alguns valores elevados encontrados ressaltam as maiores entradas de nutrientes.

$\checkmark$ As cianobactérias foram dominantes no reservatório de Itaipu, sendo que os maiores valores foram obtidos na zona de transição. $O$ aumento das concentrações de clorofila foi positivo e significativo quando relacionado com o aumento da densidade das cianobactérias.

As cianobactérias também sofreram as influências das variáveis abióticas TKN, e do fator zona do reservatório. O modelo gerado explica 57\% destas relações.

$\checkmark$ Os peixes que exerceram maior relação sobre as concentrações de cianobactéria foram os onívoros, além do fator zona do reservatório. O modelo explica cerca de $83 \%$ da relação da pressão destes grupos de peixes sobre estas algas.

$\checkmark$ O mapará, sendo a única espécie de peixe zooplanctívoro, não apresentou efeito controlador sobre as densidades de zooplâncton, e o seu desenvolvimento foi relacionado positivamente com as cianobactérias, indicando o crescimento das mesmas.

$\checkmark$ A curimba (Prochilodus lineatus) foi a única espécie a constituir o grupo dos iliófagos, tendo efeito positivo em relação a clorofila-a, cujas concentrações aumentaram de acordo com o aumento da biomassa dos iliófagos.

$\checkmark$ Os onívoros e detritívoros foram os grupos de guildas tróficas que apresentaram um efeito controlador sobre as cianobactérias e clorofila-a, indicando que o aumento 
destes grupos de peixes deplecionam as concentrações de cianobactérias no reservatório.

$\checkmark$ Os píscívoros apresentaram um efeito negativo em relação à qualidade da água do reservatório de Itaipu, no qual o efeito de controle é indicado sobre as biomassas de onívoros e detritívoros.

$\checkmark$ A produção pesqueira foi estimada pela relação com a concentração de cianobactérias, e esta foi a variável que melhor explicou esta predição, com 68\%.

$\checkmark$ A utilização do índice morfoedáfico (MEI), com a relação de dados de captura, pode gerar modelos preditivos que estimam a produtividade pesqueira no reservatório de Itaipu. As relações do MEI com a clorofila- $a$ e a transparência da água indicam que este índice pode representar um efeito de predição em futuras relações com a captura de peixes. 


\section{REFERÊNCIAS BIBLIOGRÁFICAS}

ABUjanRA, F \& AGOSTINHO, A.A. (2002). Dieta de Hypophtalmus edentatus (Spix, 1829) (Osteichthyes, Hypophtalmidae) e variações de seu estoque no reservatório de Itaipu. Acta Scientiarum v. 24, n. 2, p. 401-410.

AGOSTINHO, A.A. \& GOMES, L.C. (2005). O manejo da pesca em Reservatórios da Bacia do Alto Rio Paraná: avaliação e perspectivas. In: NOGUEIRA, M.G., HENRY, R.; JORCIN, A. (Eds.) Ecologia de Reservatórios. Ed. Rima. São Carlos, 459p.

AGOSTINHO, A.A.; OKADA, E.K.; GREGORIS, J. (1994). Caracteristicas economicas y sociales de las actividades pesqueras en el Embalse de Itaipu, Brasil. In: SIMPÓSIO REGIONAL SOBRE MANEJO DE LA PESCA EM EMBALSES EN AMERICA LATINA, 24 al 28 oct 1994, Habana, Cuba. /Rome/ :FAO, 1994. 100p

AGOSTINHO. A.A.; FERREIRA, V. S.; JÚLIO JR, H.F.; MINTE-VERA, C.V.; OLIVEIRA, E.F.; OKADA, E.K.; PAGIORO, T.A.; ROBERTO, M.C.; SUZUKI, H.I.; THOMAZ, S.M.; ABUJANRA, F. (1997a). Variações espaço-temporais na ictiofauna e suas relações com as condições limnológicas no reservatório de Itaipu. Relatório Anual. Maringá, PR. 330p.

AGOSTINHO, A.A.; JULIO JR., H.F.; GOMES, L.C.; BINI, L.M.; AGOSTINHO, C.S. (1997b). Composição, abundância e distribuição espaço-temporal da ictiofauna. In: A.E.A.M. VAZZOLER, A.A. AGOSTINHO \& N.S. HAHN (Eds.). A Planicie de Inundação do Alto Rio Paraná: aspectos físicos, biológicos e socioeconômicos. Maringá: EDUEM. p. 179-208.

AGOSTINHO, A.A.; OKADA, E.K.; GREGORIS, J. (1999). A pesca no Reservatório de Itaipu: Aspectos sócio-econômicos e impactos do represamento In: HENRY, R. (Ed.). Ecologia de reservatórios: estrutura, função e aspectos sociais. FUNDIBIO/ FAPSP 800p 
ANDERSON, G.; GRANÉLI, W.; STENSON, J. (1988). The influence of animals on phosphorus cycling in lake ecosystems. Hydrobiologia. 170: 267-284.

ANDRADE, L.F., BRUNKOW, R.F., XAVIER, C.F.; DOMINGUES, L.L. (1988) Fitoplâncton e características físico-químicas do reservatório de Itaipu. In: TUNDISI, J.G. (Ed.). Limnologia e Manejo de Represas. Série: Monografias em Limnologia, volume 1 (tomo 1).

APHA (Americam Public Health Association). (1985). Standard Methods for the Examination of Water and Wastewater, $16^{\text {th }}$ ed. APHA. Washington. DC. 1134 pp.

ARCIFA, M.S.; NORTHCOTE, T.G., FROEHLICH, O. (1986). Fish-zooplankton interactions and their effects on water quality of a tropical Brazilian reservoir. Hydrobiologia. 139: 49-58.

ARCIFA, M.S.; STARLING, F.L.R.; SIPAÚBA-TAVARES, L.H.; LAZZARO, X.T. (1995). Experimental limnology. In: TUNDISI, J.G.; BICUDO, C.E.M.; MATSUMURA-TUNDISI, T. (Eds.) Limnology in Brazil. ACB/SBL, RJ, p. 257281.

BACA, R.M. \& DRENNER, R.W. (1995). Do the effects of piscivorus largemouth bass cascade to the plankton? Hydrobiologia. 316: 139-151.

BELL, T.; NEILL, W.E.; SCHLUTER, D. (2003). The effect of temporal scale on the outcome of trophic cascade experiments. Oecologia (2003) 134:578-586

BENNDORF, J.; KNESCHKE, K. KOSSATZ; PENZ, E. (1984). Manipulation of the pelagic food web by stocking with predaceous fish. Int. Revue ges. Hydrobiologia. 69: 407-428.

BENNDORF, J.; SCHULZ, H., BENNDORF, A., UNGER, R., PENZ, E., KNESCHKE, K., KOSSATZ; K., DUMER, R., HORING, U., KRUSPE, R. \& REICHEL, S. (1988). Food web manipulation by enhancement of piscivorus fish stocks: long-term effects in the hypertrophic Bautzen reservoir. Limnologica (Berl.) 19:97-110.

BENNDORF, J.; BÖING, W; KOOP, J; NEUBAUER, I. (2002) Top-down control of phytoplankton: the role of time scale, lake depth and trophic state. Freshwater Biology 47, 2282-2295

BINI, L.M. (2003). Monitoramento da qualidade da água no reservatório de Itaipu. Relatório Final- AS CT/ 0044/2002- Itaipu Bionacional. Junho, 2003. 34p. 
BLANCHER, E. C. (1984). Zooplankton-trophic relationship in some north and central Florida lakes. Hydrobiologia, 109: 251-263.

BORGHETTI, J. R., AGOSTINHO, A. A. \& NAKATANI, K. (1988). Administração Pesqueira no reservatório de Itaipu. In: TUNDISI, J.G. (Ed.). Limnologia e Manejo de Represas. Série: Monografias em Limnologia, volume 1 (tomo 2).

BORER, E.T.; SEABLOOM, E.W.; SHURIN, J.B.; ANDERSON, K.E.; BLANCHETTE, C.A.; BROITMAN, B.; COOPER, S.D.; HALPERN, B.S. (2005). What determines the strength of a trophic cascade? Ecology, 86(2), pp. $528-537$

BOUVY, M.; FRANCA, L.B.; CARMOUZE, J.P. (1998). Compartimento microbiano no meio pelágico de sete açudes do Estado de Pernambuco (Brasil). Acta Limnol. Brasil. 10: 93-101.

BRABRAND, A., FAAFENG, B.; NILSSEN, J.P.M. (1990). Relative importance of phosphorus supply to phytoplankton production: fish excretion versus external loading. Can. J. Fish. Aquat. Sci. 47:364-372.

BRETT, M.T. \& GOLDMAN, C.R. (1996). A meta-analysis of the freshwater trophic cascade. Proc. Natl. Acad. Sci. USA. Vol. 93, pp. 7723-7726.

BRETT, M.T. \& GOLDMAN, C.R. (1997). Consumer versus resource control in freshwater pelagic food webs. Science 275:354-386.

BROOKS J.L. \& DODSON S.I. (1965) Predation, body size and composition of plankton. Science, 150, 28-35.

CALIJURI, M.C. (1989) respostas fisiológicas da comunidade fitoplanctônica e fatores ecológicos com diferentes estágios de eutrofização. Tese (Doutorado). EESC, USP, São Carlos- SP. 293p.

CALIJURI, M.C. \& TUNDISI, J.G. (1990). Limnologia Comparada das Represas do Lobo (Broa) e Barra Bonita - Estado de São Paulo: Mecanismos de Funcionamento e Bases para o Gerenciamento. Rev. Brasil. Biol. 50(4): 893-913.

CALIJURI, M.C.; TUNDISI, J.G., HENRY, R.; IBAÑEZ, M.S.R.; MATSUMURATUNDISI, T.; ROCHA, O. (1997). Changes in light attenuation in fifteen lakes and its relationship with chlorophyll and particulate material, during summer and winter. In: SAIJO, Y. \& TUNDISI, J.G. (Eds.). Limnological studies in Rio Doce Valley Lakes, Brazil. Nagoya University, Nagoya, Japan.

CARPENTER, S.R. \&. KITCHELL, J.F. (1988). Consumer control of lake productivity. BioScience 38:764-769. 
CARPENTER, S.R.; KITCHELL, J.F. (1993). The Trophic Cascade in Lakes. Cambridge University Press: 383. pp.

CARPENTER, S.R.; KITCHELL, J.F.; HODGSON, J.R. (1985). Cascading trophic interactions and lake productivity fish predation and herbivory can regulate ecosystems. BioScince. 35: 634-639.

CARPENTER, S.R.; COLE, J.J.; HODGSON, J.R.; KITCHELL, J.F.; PACE, M.L.; BADE, D.; COTTINGHAM, K.L.; ESSINGTON, T.E.; HOUSER, J.N.; SCHINDLER, A.E. (2001). Trophic cascades, nutrients, and lake productivity: whole-lake experiments. Ecological Monographs, 71(2), pp. 163-186

CENTENO, A.J. (1999). Curso de Estatística Aplicada à Ecologia. Ed. da UFG, Goiânia. 234p.

CETESB. Parâmetros para análise da qualidade de água. Disponível em: $<$ http://www.cetesb.sp.gov.br/Agua/rios/variáveis.asp> Acesso em 08 jun. 2006.

CRISMAN, T.L. \& BEAVER, J.R. (1990). Applicability of planktonic biomanipulation: for managing eutrophication in the subtropics. Hydrobiologia. 200/2001: 177-185.

DAVIES, W.D. (1972). Progress report $\mathrm{n}$ fisheries development in Northeastern. II Reservoir fisheries on Northeastern Brazil. International center for Aquaculture Research and Development. 2:1-17.

DE BERNARDI, R. \& GIUSSANI, G. (2001). Diretrizes para o gerenciamento de Lagos. Volume 7 - Biomanipulação para o gerenciamento de Lagos $e$ Reservatórios. $221 \mathrm{pp}$.

DEMELO, R.; FRANCE, R.; MCQUEEN, J.D. (1992). Biomanipulation: Hit or myth?. Limnol. Oceanogr.. 37(1). 192-207.

DNOCS (1990). Dados sobre a administração da pesca em açudes públicos relativos ao período de 1948 a 1990. DNOCS, Diretoria de Pesca e Piscicultura, Fortaleza, Ceará, Brasil.

DRENNER, R.W.; HAMBRIGHT, K.D. (1999). Biomanipulation of fish assemblages as a lake restoration technique. Archiv Fur Hydrobiologie. 146: (2) 129-165.

DRENNER, R.W.; SMITH, J.D.; THRELKELD, S.T. (1996). Lake trophic state and the limnological effects of omnivorus fish. Hydrobiologia. 319: 213-223.

DRENNER, R.W.; GALLO, K.L.; BACA, R.M.; SMITH, J.D. (1998). Synergistic effects of nutrients loading and omnivorus fish on phytoplankton biomass. Can. J. Fish. Aquat. Sci. 55: 2287-2296. 
ELSER, J.J. \& GOLDMAN, C.R. (1991). Zooplankton effects on phytoplankton in lakes of contrasting trophic status. Limnol. Oceanogr. 36: 64-90

ESPÍNDOLA, E.L.G.; MATSUMURA-TUNDISI, T.; RIETZLER, A.C. (2000) Heterogeneidade espacial do Reservatório de Tucuruí (Estado do Pará, Amazônia, Brasil) e a distribuição das espécies zooplanctônicas. Rev. Bras. Biol., maio 2000, vol.60, no.2, p.179-194.

ESTEVES, F.A. (1988). Fundamentos de limnologia. Editora Interciência/ FINEP. Rio de Janeiro. 575p.

FAAFENG, B.A.; BRABRAND, A. (1990). Biomanipulation of a small, urban lake removal of fish exclude bluegreen blooms. Verh. Internat. Verein. Limnol. 24: 597-602.

FERRAREZE, M.F.F.; NOGUEIRA, M.G.; VIANNA, N.C. (2005). Transporte de nutrientes e sedimentos no rio Paranapanema (SP/PR) e seus principais tributários nas estações seca e chuvosa. In: NOGUEIRA, M.G., HENRY, R.; JORCIN, A. (Eds.) Ecologia de Reservatórios. Ed. Rima. São Carlos, 459p.

FIGUEREDO, C.C. (2000). Efeitos da tilápia (Oreochomis niloticus) nas características físicas e químicas e estrutura da comunidade fitoplanctônica do reservatório da Usina Hidroelétrica de Furnas (MG). Dissertação (Mestrado). UFMG. Belo Horizonte. 150p.

GESTEIRA, G.C.V. (1978). Aspectos biológicos ligados à produtividade de pesca nos açudes públicos da área do "Polígono das Secas"- Nordeste do Brasil. Dissertação (Mestrado) UFRJ. 143p.

GOPHEN, M. (1995). Long-term (1970-1990) whole lake biomanipulation. In: DE BERNARDI, R. \& GIUSSANI, G. (Eds.). Biomanipulation in in Lakes and Reservoirs Management: 171-184.

GRANDO, J.V. (1989). Considerações sobre o estagio atual da ictiofauna e aspectos alimentares de quatro espécies de peixes do Lago Paranoá, Brasília-DF. Brasília. 98 pp. (Dissertação de Mestrado). Universidade de Brasília. Brasília.

GULATI, R.D. (2001). Manipulação das populações de peixes visando a recuperação de Lagos eutrofizados em regiões temperadas In: DE BERNARDI, R. \& GIUSSANI, G. 2001. Biomanipulação para o gerenciamento de lagos e reservatórios. Cap. 3, p.33-51. 
GURGEL, J.J.S \& FERNANDO, C.H. (1994). Fisheries in the semi-arid Northeast Brazil with special reference to the role of tilapias. Int. Revue ges. Hydrobiol.79: 77-94.

HAIRSTON, N.G. Jr. \&. HAIRSTON, N.G. (1997). Does food web complexity eliminate trophic-level dynamics? American Naturalist 149:1001-1007.

HAMBRIGHT, K.D. (1994). Morphological constraints in the piscivore-planktivore interaction: Implications for the trophic cascade hypothesis. Limnol. Oceanogr. 39(4): 897-912.

HAMBRIGHT, K.D.; DRENNER, R.W.; MCCOMAS, S.R. (1991). Gape-limited piscivores, planktivores size refuges, and the trophic cascade hypothesis. Arch. Hydrobiol. 121 (4): 389-404.

HANSON, J.M.; LEGGET, W.C. (1982). Empirical prediction of fish biomass and weight. Can. J. Fish. Aquat. Sci. 39: 257-263.

HANSSON, L.A.; GYLLSTROEM, M.; STAAHL-DELBANCO, A.; SVENSSON, S. (2004). Responses to fish predation and nutrients by plankton at different levels of taxonomic resolution. Freshwater Biology 49, 1538-1550.

HASAN, M.R.; MONDAL, M.A.W.; MIAH, M.I.; KIBRIA, M.G. (2001) Water Quality Study of Some Selected Oxbow Lakes with Special Emphasis on Chlorophyll-a. In: De Silva, S.S. (Ed.). Reservoir and Culture-based Management Fisheries: Biology and Management

HENDERSON, F. \& WELCOME, R.L. (1974. The relationship of yield to morphoedaphic index and number of fishermen in African fisheries. Committee for Inland Fisheries of Africa. Occas. pap. 1. FAO, Rome, 19p.

HENRIKSON, L.; NYMAN, H.G.; OSCARSON, H.G.; STENSON, J.A. (1980). Trophic changes without changes in the external nutrient loading. Hydrobiologia 68: 257-263.

HENRY, R. (1990). Amônia ou fosfato como agente estimulador do crescimento do fitoplâncton na represa de Jurumurim (Rio Paranapanema, SP)?. Ver. Brasil. Biol., 50 (4): $883-892$

HENRY, R. \& SIMÃO, A.C. (1990). Aspectos sazonais da liberação potencial por N, P e Fe no fitoplâncton na represa de Barra Bonita (Rio Tietê, SP). Rev. Brasil. Biol., 48 (1): 1-14. 
HODGSON, J.R.; HE, X.; KITCHELL, J.F. (1996). The fish populations. In: CARPENTER, S.R. \& KITCHELL, J.F. (Eds.). The trophic cascade in lakes. Cambridge University Press. 385p.

HRBÁČEK, J.; DVORÁKOVÁ, M.; KORÍNEK, V.; PROCHÁZKOVÁ, L. (1961).

Demonstration of the effect of the fish stock on the species composition of zooplankton and the intensity of the whole plankton association. Verh. Inter. Limnol. 14: 192-195.

HUITEMA, B.E. (1980). The analysis of covariance and alternatives. John Wiley \& Sons. $445 \mathrm{p}$.

IAP (2003). Estudos Limnológicos do Reservatório de Itaipu. Relatório anual. Contrato Itaipu Binacional/Instituto Ambiental do Paraná. Curitiba. 107 p.

Itaipu Binacional (2006). Disponível em www.itaipu.gov.br. Acesso em 01/08/2006 IWAKUMA, T.; HAYASHI, H.; YASUDA, I.; HANAZATO, T.; TAKADA, K. (1990). Impact of whitefish on am enclosure ecosystem in a shallow eutrophic lake: changes in nutrients concentrations, phytoplankton and zoobenthos. Hydrobiologia. 200/201: 141-152.

JEPPENSEN, E.; JENSEN J.P.; KRISTENSEN, P.; SONDERGAARD, M.; MORTENSEN, E.; SORTKAER, O.; OLRIK, K. (1990). Fish manipulation as a lake restoration tool in shallow, eutrophic, temperate lakes 2: Threshold levels, long-term stability and conclusions. Hydrobiologia. 200/201: 219-227.

JEPPENSEN, E.; JENSEN J.P.; SONDERGAARD, M.; LAURIDSEN, T.; PEDERSEN, L.J.; JENSEN, L. (1997). Top-down control in freshwater lakes: the role of nutrient state, submerged macrophytes and water depth. Hydrobiologia 342/343: 151-164.

JEPPENSEN, E.; JENSEN, J.P; SØNDERGAARD, M.; LAURIDSEN, T.; LANDKILDEHUS, F. (2000). Trophic structure, species richness and biodiversity in Danish lakes: changes along a phosphorus gradient. Freshwater Biology (45) $201-218$

JEPPENSEN, E.; SØNDERGAARD, M.; MAZZEO, N.; MEERHOFF, M.; BRANCO, C.C.; HUSZAR, V.; SCASSO, F. (2005). Lake restoration and biomanipulation in temperate lakes: relevance for subtropical and tropical lakes. In: REDDY, M.V. \& MOSS, B. (Eds.) Tropical eutrophic lakes: the restoration and management. Science Publishers, USA.

JEZIERSKA, B. (1979). Fish metabolism. Polish Ecological Studies. 5(3): 43-51. 
JØRGENSEN, J. E. \& VOLLENWEIDER (2000). Problemas de Lagos e Reservatórios. In: S. E. JØRGENSEN \& R. A. VOLLENWEIDER (eds) Diretrizes para o Gerenciamento de Lagos. Volume 1: Princípios para o Gerenciamento de Lagos. KARJALAINEN, H.S. SEPPALA; WALLS, M. (1998). Nitrogen, phosphorus and Daphinia grazing in controlling phytoplankton biomass and composition - An experimental study. Hydrobiologia.309-321.

KASPRZAK, P. (2001). Objetivos da Biomanipulação. In: DE BERNARDI, R. \& GIUSSANI, G. (Eds.) Diretizes para o gerenciamento de Lagos, Volume 7 Biomanipulação para o gerenciamento de Lagos e Reservatórios. Cap. 2, 13-21.

KIMMEL, B.L.; LIND. O.T.; PAULSON, L.J. 1990. Reservoir primary production. In : THORTON, K.W.; KIMMEL, B.L.; PAYNE, F.E.; (Eds.). Reservoir Limnology: ecological perspectives. New York: John Wiley \& Sons. p.133-194.

KOTAS, J.E. (2004). Dinâmica de populações e pesca do tubarão martelo Sphyrna lewini (Grffith \& Smith, 1834) capturado no mar territorial e Zona Econômica Exclusiva so sudeste-sul do Brasil. Tese (Doutorado). CRHEA/ EESC/ USP. São Carlos, 377p.

KURMAYER, R.; WANZENBOCK, J. (1996). Top-down effects of under yearling fish on a phytoplankton community. Frehswater Biology. 36: 599-609.

LAMARRA, V.A.JR. (1975). Digestive activities of carp as a major contributor to the nutrient loading of lakes. Verb. Internat. Verein. Limnol. 19: 2461-2468.

LANSAC-TÔHA, F.A., VELHO, L.F.M.; BONECKER, C. C. (1999). Estrutura da Comunidade Zooplanctônica Antes e após a Formação do Reservatório de Corumbá-GO. In: HENRY, R. (ed.). Ecologia de Reservatório: Estrutura, Função e Aspectos FUNDIBIO/ FAPESP, Botucatu, SP

LANSAC-TÔHA, F.A., BONECKER, C.C.; VELHO, L.F.M. (2005). Estrutura da Comunidade Zooplanctônica em reservatórios. In: RODRIGUES, L., THOMAZ, S.M., AGOSTINHO, A.A.; GOMES, L.C. (Eds.). Biocenose em ReservatóriosPadrões espaciais e temporais. Rima Editora, São Carlos, SP

LATHROP, R.C.; JOHNSON, B.M.; JOHNSON, T.B.; VOGELSANG, M.T.; CARPENTER, S.R.; HRABIK, T.R.; KITCHELL, J.F.; MAGNUSON, J.J.; RUDSTAM, L.G.; STEWART, R.S. (2002). Stocking piscivores to improve fishing and water clarity: a synthesis of the Lake Mendota biomanipulation project. Freshwater Biology 47, 2410-2424. 
LAZZARO, X. (1987). A review of plankitivorous fishes: their evolution, feeding behavior, selectivity, and impacts. Hydrobiologia 146: 97-167.

LAZZARO, X.T. (1991). Feeding convergence in South American and African zooplaktivorous cichlids Geophagus brasiliensis and Tilapia rendalli. Environmental Biology of Fishes. 31: 283-293.

LAZZARO, X.T. (1997). Do the trophic cascade hypothesis and classical biomanipulation approaches apply to tropical lakes/reservoirs? Verh. Internat. Verein. Limnol. 26: 719-730.

LAZZARO, X. GRANDO, J.; RIBEIRO, M.; RIBEIRO FILHO, R.A.; MATA, M.R.; ARAÚJO, A.T.P.; VASCONCELOS, S. (1998). Serviço de Levantamento Hidroacústico (Ecossondagem) no Lago Paranoá: Calibração pela pesca Experimental com Redes de Emalhar. In: Serviço de levantamento hidroacústico (Ecossondagem) no Lago Paranoá. Brasília, DF. FUNDAÇÃO SUSTENTABILIDADE E DEENVOLVIMENTO. Brasília/ Relatório Final. 2449.

LAZZARO X., M. BOUVY, V.S. de OLIVEIRA, R.A. RIBEIRO FILHO, L.T. de SALES, A.R.M. de VASCONCELOS, M.R.da MATA JR \& L. WILLADINO (2002). Semi-arid Brazilian Northeast reservoirs: fish-plankton food webs, relative fish biomass predictors, and fish yields vs. water quality optimization. International Workshop on "Food Web Effects of Fish in the Lake Ecosystem", IGB, Rheinsberg-Linow, Germany, May 31-June 3, 2000. Disponível em: http://www.mpl.ird.fr/flag/lazzaro/projects/acudes/index.html.

LAZZARO, X.; BOUVY, M.; RIBEIRO-FILHO, R.A.; OLIVIERA, V.S.; SALES, L.T.; VASCONCELOS, A.R.M.; MATA, M.R. (2003). Do fish regulate phytoplankton in shallow eutrophic Northeast Brazilian reservoirs? Freshwater Biology. 48, 649-668.

LEBOURGES- DHAUSSY, A.; DHAUSSY, P.; LAZZARO, X. (1998). Serviço de Levantamento Hidroacústico (Ecossondagem) no Lago Paranoá, Brasília, DF. FUNDAÇÃO SUSTENTABILIDADE E DESENVOLVIMENTO. Brasília/ Relatório Final. 50-70.

LEGENDRE, PIERRE \& LOUIS LEGENDRE. 1998. Numerical ecology. 2nd English edition. Elsevier Science BV, Amsterdam. xv +853 pages. 
LEVENTER, H. \& TELTSCH, B. (1990). The contribution of silver carp (Hypophthalmichthys molitrix) to the biological control of Netofa reservoirs. Hydrobiologia. 191: 47-55.

MARGALEF, R. (1975) Typology of reservoirs. Verh. Internat. Verein. Limnol. 19, $1841-8$

MAROUELLI, M.H., EMERIC, R.H.S., CAVALCANTI, C.G.B., RUTKOWSKI, E., SALES, M.E.C., SEGUNDO, S.M.A., FORATTINI, G.D., PERA, R.H. \& CASTRO, I. Bases para uma manejo racional de reservatórios (1988). Administração Pesqueira no reservatório de Itaipu. In: TUNDISI, J.G. (Ed.). Limnologia e Manejo de Represas. Série: Monografias em Limnologia, volume 1 (tomo 2).

MARSHALL, B.E. (1984). Predicting ecology and fish yields in African Reservoirs from preimpoundment physico- chemical data. FAO, CIFA Technical Paper 12, $36 \mathrm{p}$.

MARZOLF, G.R. (1990). Reservoirs as environments for zooplankton. In: THORNTON, K.W.; KIMMEL, B.L.; PAYNE, F.E. (Eds.). Reservoir limnology: ecological perspectives. New York: J. Wiley \& sons, ch. 7, p. 195-208

MATSUMURA-TUNDISI, T.; NEUMANN-LEITÃO, S.; AGUENA, L.S.; MIYAHARA, J. (1990). Eutrofização da represa de Barra Bonitas: estrutura e organização da comunidade de Rotifera. Rev. Brás. Biol. v. 50, n.4, pp. 923-935.

MCQUEEN, J.D. (1990). Manipulating lake community structure: where do we go from here? Freshwater Biology 23: 613-620

MCQUEEN, J.D. (1998). Freshwater food web biomanipulation: A powerful tool for water quality improvement, but maintenance is required. Lakes \&Reservoirs: Research and Management. 3: 83-94.

MCQUEEN, D.J.; POST, J.R.; MILLS, E.L. (1986). Trophic relationships in freshwater pelagic ecosystems. Can. J. Fish. Aquat. Sci. 43. 1571-81.

MCQUEEN, D.J.; JOHANNES, M.R.S.; POST, J.R.; STEWART, T.J.; LEAN, D.R.S. (1990). Biomanipulation and community structure at Lake St. George, Ontario. Canada. Verch. Internat. Verein. Limnol.24. 335-338.

MCQUEEN, D.J.; FRANCE, R.; KRAFT, C. (1992). Confounded impacts of planktivorus fish on freshwater biomanipulations. Arch. Hydrobiol. 125: 1-24. 
MEHNER, T.; HÖLKER, F.; KASPRZAK, P. (2005). Spatial and temporal heterogeneity of trophic variables in a deep lake as reflected by repeated singular samplings. OIKOS 108: 401- 409

MEIJER, M.L.; DEBOOIS, I.; SCHEFFER, M.; PORTIELJE, R.; HOSPER, H. (1999). Biomanipulation in shallow lakes in The Netherlands: an evaluation of 18 case studies. Hydrobiologia 408/409: 13-30.

MELACK, J.M. (1976) Primary productivity and fish yields in tropical lakes. Trans. Am. Fish. Soc. 105:575-580

MINILLO, A. (2005). Análise da distribuição, densidade e toxicidade de florações de cianobactérias e suas toxinas nos reservatórios do Médio e Baixo rio Tietê (SP) e relação com as características limnológicas do sistema. Tese (Doutorado). CRHEA/ EESC/ USP. São Carlos, 394p.

MITSCH, W.J. \& JØRGENSEN, J.E. (1989). Ecological Enginnering- An introduction to Ecotechnology. Wiley - Interscience. 577 pp.

MOLLE, F. (1991). Caractéristiques et potentialités des "açudes" du Nordeste brésilien. Doctoral Dissetation, Université Montpelier II, 380p.

NOGUEIRA, M.G., JORCIN, A., VIANNA, N.C.; DE BRITTO, Y.C.T. (2005). Reservatório em Cascata e os efeitos na limnologia e Organização das Comunidades Bióticas (Fitoplâncton, Zooplâncton e Zoobentos) - Um Estudo de Caso no Rio Paranapanema (SP/PR). In: NOGUEIRA, M.G., HENRY, R.; JORCIN, A. (Eds.) Ecologia de Reservatórios. Ed. Rima. São Carlos, 459p.

NUSCH, E.A., 1980. Comparision of different methods for chlorophyll and pheopigment determination. Arch. Hydrobiol. Beih. Erg. Limnol., 14:14-36.

ODUM, E.P. (1988). Ecologia. Ed. Guanabara, Koogan AS, Rio de Janeiro. 434 pp.

OGLESBY, R.T. (1977). Relationships of fish yield to lake phytoplankton standing crop, production and morphoedaphic factors. Journal of Fisheries Research Board, Canada 34:2271-2279.

OKADA, E.K. (2001). Gradientes espaço-temporais na pesca artesanal no reservatório de Itaipu. Tese (Doutorado). UEM/ NUPELIA. Maringá, PR. 54p.

OLIVEIRA, E.F.; MINTE-VERA, C.V.; GOULART, E. (2005). Structure of fish assemblages along spatial gradients in a deep subtropical reservoir (Itaipu Reservoir, Brazil-Paraguay border). Environmental Biology of Fishes 72: 283304. 
OVERBECK, J. (2000). Conceitos de Ecossistema. In: S. E. JØRGENSEN \& R. A. VOLLENWEIDER (eds.) Diretrizes para o Gerenciamento de Lagos. Volume 1: Princípios para o Gerenciamento de Lagos.

PAGIORO, T.A. \& THOMAZ, S.M. (2002). Longitudinal patterns of sedimentation in a deep monomitc subtropical reservoir Itaipu (Brazil- Paraguay). Archiv für Hydrobiologie, Stuttgart, v. 154, n. 3, p. 515-528, June

PAGIORO, T.A., ROBERTO, M.C., THOMAZ, S.M., PIERINI, S.A.; TAKA, M. (2005a). Zonação Longitudinal das Variáveis limnológicas Abióticas em Reservatórios. In: RODRIGUES, L., THOMAZ, S.M., AGOSTINHO, A.A.; GOMES, L.C. (Eds.). Biocenose em Reservatórios- Padrões espaciais e temporais. Rima Editora, São Carlos, SP

PAGIORO, T.A., THOMAZ, S.M.; ROBERTO, M.C. (2005b). Caracterização Limnológica Abiótica dos Reservatórios. In: RODRIGUES, L., THOMAZ, S.M., AGOSTINHO, A.A.; GOMES, L.C. (Eds.). Biocenose em Reservatórios- Padrões espaciais e temporais. Rima Editora, São Carlos, SP

PAIVA, M.P.; PETRERE, M.J.; PETENATE, A.J.; NEPOMUCENO, F.H.; VASCONCELOS, E.A. (1994). Relationship between the number of predatory fish species and fish yield in large northeastern Brazilian reservoirs. Rehabilitation of Freshwater Fisheries: 120-129.

PEDRO, F. (1995). Alimentação e Comportamento Predatório do tucunaré Cichla ocellaris, Bloch \& Schneider, 1801 (Osteichihyes: Cichlidae). Dissertação (Mestrado) UFPB. João Pessoa. 132p.

PELICICI, F.M.; ABUJANRA, F.; FUGI, R.; LATINI, J.D.; GOMES, L.C.; AgOstinho, A.A. (2005). A Piscivoria Controlando a Produtividade em Reservatórios: Explorando o Mecanismo Top Down. In: RODRIGUES, L., THOMAZ, S.M., AGOSTINHO, A.A.; GOMES, L.C. (Eds.). Biocenose em Reservatórios- Padrões espaciais e temporais. Rima Editora, São Carlos, SP PEREIRA, J.M.A. \& RIBEIRO FILHO, R.A. (2004). Efeitos da excreção de tilápias (Tilapia rendali e Oreochromis niloticus) em reservatórios e viveiros de piscicultura. In: ESPÍNDOLA, E.L.G. \& WENDLAND, E. (Eds.). Bacia Hidrográfica: diversas abordagens em pesquisa. Ed. Rima, São Carlos, 412p.

PERROW, M.; MEIJER, M.L.; DAWIDOWICZ, P.; COOPS, H. (1997). Biomanipulation in Shallow lakes: State of the art. Hydrobiologia 342/343: 355365. 
PERSSON, A. (1997). Phosphorus release by fish in relation to external and internal load in a eutrophic lake. Limnol. Oceanogr. 42(3): 577-583.

PERSSON, L.; ANDERSSON, G.; HAMIRIN, S.F.; JOHANSSON, L. (1988). Predator regulation and primary production along the productive gradient of temperate lake ecosystems. Complex Interactions in Lake Communities. 53-59.

PETERS, R.H. (1986). The role of prediction limnology. Limnol. Oceanogr. 31: 11431159

PIANA, P.A.; DA LUZ, K.D.G.; PELICICE, F.M.; COSTA, R.S.; GOMES, L.C.; AGOSTINHO. A.A. (2005). Predição e Mecanismos Reguladores da Biomassa de Peixes em Reservatórios. In: RODRIGUES, L., THOMAZ, S.M., AGOSTINHO, A.A.; GOMES, L.C. (Eds.). Biocenose em Reservatórios- Padrões espaciais e temporais. Rima Editora, São Carlos, SP

PIJANOWSKA, J. \& PREJS, A. (1997). Food-web manipulation in shallow, eutrophic lakes: bridging the gap between the role-lake approach and behavioral and demographic studies. Hydrobiologia 342/343: 305-310.

PINTO-COELHO, R.M.; AZEVEDO, L.M.A., RIZZI, P.E.V., BEZERRA-NETO, J.F.; ROLLA, M.E. (2005). Origens e Efeitos do Aporte Externo de Nutrientes em um Resevatório tropical de Grande Porte: Reservatório de São Simão (MG/GO). In: NOGUEIRA, M.G., HENRY, R.; JORCIN, A. (Eds.) Ecologia de Reservatórios. Ed. Rima. São Carlos, 459p.

POWER, M.E. (1990). Effects of fish in river food webs. Science 250:811-814.

PREJS, A.; PIJANOWSKA, J.; KOPERSKI, P.; MARTYNIAK A.; BORÓN S.; HLIWA, P. (1997). Food-web manipulation in a small, eutrophic Lake Wirbel. Poland: Long-term changes in fish biomass and basic measures of water quality. A case study. Hydrobiologia 342/343: 383-386.

QUIROS, R. (1990). Predictors of relative fish biomass in lakes and reservoirs of Argentina. Can. J. Fish. Aquat. Sci.47: 928-939.

QUIROS, R. (1998). Reservoir stocking in Latin America, an evaluation. Ppp. 97-117. In: PETR, T (ed.). Inland fishery enhancement. Papers present at the FAO/DFID Expert Consultation on Inland Fishery Enhancements. Dhaka. Bangladesh. 7-11 April, 1997. FAO Fisheries Technical Paper. 374. Rome. FAO. 463p.

QUIRÓS, R. \& BOVERI, M.B. (1999). Fish effects on reservoir thophic relationships. In: TUNDISI, J.G. \& STRAŠKRABA, M. (Eds.) Theoretical Reservoir Ecology and its Applications. IIE, BAC, Backuysv Publishers. 529-546, 592p. 
RAMIREZ, J.J.R. (1996). Variação especial vertical e nictimeral da estrutura da comunidade fitoplanctônica e variáveis ambientais em quatro dias de amostragem de diferentes épocas do ano na Lagoa das Garças, São Paulo. Tese (Doutorado). USP, São Paulo. 300p.

REGIER, H.A. \& HENDERSON, F. (Eds.) (1980). Comparative studies on freshwater fisheries. FAO (Food and Agriculture Organization of the United Nations). Fish. Tec. Pap. 46p.

REJAS, D.; CLERCK, L.; AUWERKERKEN, J.; TAK, P.; MEESTER, L. (2005). Plankton dynamics in a tropical floodplain lake: fish, nutrients, and the relative importance of bottom-up and top-down control. Freshwater Biology 50, 52-69.

REYNOLDS, C.S. (1984). The ecology of freshwater phytoplankton - Cambrige Studies in Ecology. Cambrige University Press. Great Britain. 384p.

REYNOLDS, C.S. (1987). The response of phytoplankton communities to changing lake environments. Schweiz. Z. Hydrobiol. 49/2 pp. 220-236.

REYNOLDS, C.S. (1994). The ecological basis for the successful biomanipulation of aquatic communities. Arch. Hydrobiol. 130: 1-33.

RIBEIRO FILHO, R.A. (1999). Caracterização de dietas alimentares de peixes predadores em açudes de Pernambuco e no Lago Paranoá (Brasília - DF). Monografia.Universidade Federal Rural de Pernambuco. Recife. 52p

RIBEIRO FILHO, R.A. (2002). Estudo experimental de biomanipulação: análise dos impactos ambientais de duas espécies de predadores no controle de tilápia no Lago Paranoá (Brasília - DF). Dissertação (Mestrado). CRHEA/ EESC/ USP, São Carlos

ROCHA, O.; SENDACZ, S.; MATSUMURA-TUNDISI, T. (1995). Composition, biomass and productivity of zooplankton in natural lakes and reservoirs of Brazil. tropical reservoir: In: TUNDISI, J.G.; BICUDO, C.E.M.; MATSUMURATUNDISI, T. (Eds.) Limnology in Brazil, Rio de Janeiro: ABC/ SLB, 151-165.

ROCHE, K.F. \& ROCHA, O. (2005). Aspectos de predação por peixes em lagos e represas, com enfoque na planctivoria. In: ROCHE, K.F. \& ROCHA, O. (Eds.). Ecologia trófica de peixes com ênfase na planctivoria nos ambientes lênticos de água doce no Brasil. Ed. Rima. São Carlos, 136p.

ROCHE, K.F.; SAMPAIO, E.V.; MATSUMURA-TUNDISI, T.; TUNDISI, J.G.; DUMONT, H.J. (1993). Impact of Holoshestes heterondon Eigenmann (Pisces: 
Characidae) on the plankton community of a subtropical reservoir: The importance of predation by Chaoborus larvae. Hydrobologia. 254: 7-20.

ROCHE, K.F., ROCHA, O.; ESPÏNDOLA, E.L.G. (2005). Impacto do acará, Geophagus brasiliensis (CICHLIDAE), no plâncton da Represa do Broa: Um experimento Usando Mesocosmos. In: ROCHE, K.F. \& ROCHA, O. (Eds.). Ecologia trófica de peixes com ênfase na planctivoria nos ambientes lênticos de água doce no Brasil. Ed. Rima. São Carlos, 136p.

ROSS, C.; KLINGE, M.; HERINGA, J.; DE VRIES, D.A. (1995). Upscaling Biomanipulation in 600 ha in Lake Zuidlaardermeer. War. Sci. Tech. Vol. 31. N. 8. pp. $235-238$.

RYDER, R.A. (1965). A Method for Estimating the Potential Fish Production of Northtemperate Lakes. Transactions of the American Fisheries Society. 94: 214218.

SASS, G.G. \& KITCHELL, J.F. (2005). Can growth be used as a surrogate measure of walleye (Sunder vitreus) abundance change? Can. J. Fish. Aquat. Sci. 62: 21592168 .

SCASSO, F.; MAZZEO, N.; GORGA, J.; KRUK, J; LACEROT, G.; CLEMENTE, J.; FABIÁN, D.; BONILLA, S. (2001). Limnological changes in a sub-tropical shallow hypertrophic lake during its restoration: two years of a whole-lake experiment. Aquatic Conserv: Mar. Freshw. Ecosyst. 11: 31-44 (2001).

SCHLESINGER, D.A. \& REGIER, H.A. (1982). Climatic and morphoedaphic indices of fish yields from natural lakes. Trans. Am. Fish. Soc. 111: 1-150.

SHAPIRO, J.; WRIGHT, J. (1984). Lake restoration by biomanipulation: Round Lake, Minnesota, the first 2 years. Freshwat. Biol. 14: 371-383.

SHAPIRO, J.; LAMARRA, V.; LYNCH, M. (1975). Biomanipulation, an ecosystem approach to lake restoration. In: P. BREZONIK \& L. FOX (Eds.) Proc. Symp. Water Qualit Management Trough Biological Control. Univ. Florida Press. Gainesville. Florida: 85-96.

SIGMAPLOT (2004) for Windows Version 9.0. Systat Software, Inc.

SIGMASTAT (2004) for Windows Version 3.10. Systat Software, Inc.

SILVA, J.W.B. (1981). Recursos pesqueiros de águas interiores do Brasil, especialmente do Nordeste. DNOCS, Diretoria de Pesca e Piscicultura. Fortaleza, Ceará, Brasil. 98p. 
SONDERGAARD, M.; JEPPESEN, E; BERG, S. (1997). Pike (Esox lucius) stocking as a biomanipulation tool 2. Effects on lower trophyc levels in lake Lyng. Denmark. Hydrobiologia 342/343: 319-325.

SOUZA FILHO, E.E. \& STEVAUX, J.C. (1997). Geologia e geomorfologia do complexo do rio Baía, Curutuba, Ivinheima. In: A.E.A.M. VAZZOLER, A.A. AGOSTINHO \& N.S. HAHN (Eds.). A Planície de Inundação do Alto Rio Paraná: aspectos físicos, biológicos e socioeconômicos. Maringá: EDUEM. p. 179-208.

SPIEGEL, M.R. (1993). Estatística. $3^{\text {a }}$ Ed. Makron Books (Coleção Schaun). São Paulo. STARLING, F.L.M. (1993). Control of eutrophication by silver carp (Hypophtalmichthys molitrix) in the tropical Paranoá Reservoir (Brasília, Brazil) a mesocosm experiment. Hydrobiologia. 257: 143-152.

STARLING, F.L.M. (1998). Development of biomanipulation strategies for the remediation of eutrophication problem in a urban reservoir- Lago Paranoá. Tese (Doutorado). University of Stirling, Escócia 159p.

STARLING, F.L.M.; LAZZARO, X. (1997). Experimental investigation of the feasibility of improving water qualit by controlling exotic planktivore overpopulation in eutrophic Paranoá Reservoir (Brasíla, DF, Brazil). INTERNATIONALE VEREININIGUN FUR THEORESTISCHE UND ANGEWANDTE LIMNOLOLOGIE. VERHANDLUNGEN. v.83. p. 789-794.

STARLING, F.L.M. \& LAZZARO, X. (2000). Biomanipulation in the Trophics and Subtropics: Overview and Perspectives. In: Seminário Internacional do Lobo-Broa - 30 anos de pesquisa em Limnologia, Gerenciamento e Participação da comunidade e Bases Científicas para o Gerenciamento da Eutrofização. São Carlos, 2000. Resumos. São Carlos USP/UFSCar. V.1, p.24.

STARLING, F.L.M. \& ROCHA, A.J.A. (1990). Experimental study of planktivorous fishes on plankton community and eutrophication of a tropical Brazilian reservoir. Hydrobiologia. 200/2001: 5081-591.

STEIN, R.A.; DEVRIES, D.R.; DETTMERS, J.M. (1995). Food-web regulation by a planktivore: exploring the generality of the trofic cascade hypothesis. Can J. Fish. Aquat. Sci. 52: 2518-2526.

STIVARI, S.S., OLIVEIRA, A.P.; SOARES, J. (2005). On the climate impact of the local circulation in the Itaipu Lake Area. Climatic Change 72: 103-121 
STRAŠKRABA, M. (1998). Limnological differences between deep valley reservoirs and deep lakes. Internat. Rev. Hydrobiol. 83: 1-12.

STRAŠKRABA, M.; TUNDISI, J. G. (2000). Diretrizes para o Gerenciamento de Lagos. IIE-Instituto Internacional de Ecologia. São Carlos. 258 pp.

SYSTAT Version 10 (2000) SPSS Inc., Standart Version.

TABACHNICK, B.G. \& FIDELL, L.S. (2001). Using multivariate statistics. Allyn and Bacon, $4^{\text {th }}$ Edition, USA.

THORNTON, K.W. (1990). Perspectives on reservoir limnology. In: THORTON, K.W.; KIMMEL, B.L.; PAYNE, F.E. (Eds.). Reservoir Limnology: ecological perspectives. New York: A Wiley-Interscience. p. 1-13

TOlEDO JR., A.P.; TALARTICO, M.; CHINEZ, S.J.; AGUDO, E.G. (1983). A aplicação de modelos simplificados para a avaliação do processo de eutrofização em lagos e reservatórios tropicais. In: CONGRESSO BRASILEIRO DE ENGENHARIA SANITÁRIA E AMBIENTAL, 12, Camburiú. Anais... p.34.

TOWNSEND, S.A. (1999). The seasonal pattern of dissolved oxygen an hypolimnetic deoxygenation, in two tropical Australian reservoir. Lakes \& Reservoir: Research and Management, 4: 41-53.

TUCCI, C.E.M. (2002). Escoamento superficial. In: TUCCI, C.E.M. (Ed.). Hidrologia: Ciência e Aplicação. $3^{a}$ edição. Editora da UFRGS/ ABRH. Porto Alegre, RS.

TUNDISI, J. G. (1986a). Limnologia de represas artificiais. Boletim de Hidráulica e Saneamento. EESC-USP, 11: 1-46

TUNDISI, J. G. (1986b). Ambiente de Represas e Barragens. Ciência Hoje, 5 (27): 4954.

TUNDISI, J. G. (1990). Distribuição Espacial, Seqüência Temporal e Ciclo Sazonal do Fitoplâncton em Represas: Fatores Limitantes e Controladores. Rev. Brasil. Biol., 50 (4): 937-955.

TUNDISI, J.G. (2005) Gerenciamento integrado de Bacias Hidrográficas e Reservatórios - Estudos de Caso e Perspectivas. In: M.G. NOGUEIRA, R. HENRY \& A. JORCIN (eds) Ecologia de Reservatórios: Impactos Potenciais, ações de Manejo e Sistemas em Cascata. Editora Rima, São Carlos, SP.

TUNDISI, J. G.; MATSUMURA-TUNDISI, T.; CALIJURI, M.C. (1993). Limnology and management of Brazil. In: STRAŠKRABA, M.; TUNDISI, J.G.; DUNCAN, A. (Eds.). Comparative reservoir limnology and water quality management, Kluwer Academic, Dordrecht, The Netherlands. 
UTERMÖHL, H. (1958). Zur Vervalkammung des Quantitativen PhytoplanktonMethodik. Internationale Vereinigung für Theoretiche und Angewandte Limnologie. Mitteilung, 9: 1-38.

VANNI, M.J. \& FINDLAY, D.L. (1990). Trophic cascades and phytoplankton community structure. Ecology. 71(3): 921-937.

VELHO, L.F.M.; LANSAC-TÔHA, F.A.; BONECKER, C.C. (2005). Distribuição longitudinal da comunidade zooplanctônica em reservatórios. In: RODRIGUES, L., THOMAZ, S.M., AGOSTINHO, A.A.; GOMES, L.C. (Eds.). Biocenose em Reservatórios- Padrões espaciais e temporais. Rima Editora, São Carlos, SP

VOLLENWEIDER, R.A. (1974). A manual on methods for measuring primary production in aquatic environments. 2 ed. London, Blackwell Scientific Publications (IBP Handbook, 12): 225p.

WETZEL, R.G. (1993). Limnologia. Fundação Calouste Gulbenkian. 1011 pp.

WETZEL, R.G. (1990). Reservoir ecosystems: conclusions and speculations. In: THORNTON, K.W.; KIMMEL, B.L.; PAYNE, F.E. (Eds.). Reservoir Limnology: ecological perspectives. New York: A Wiley-Interscience. p. 227-238.

WETZEL, R.G. (2001). Limnology: Lakes and river ecosystems.San Diego: Academic press.

WRIGHT, S. (1981). Alguns dados da física e da química das águas dos açudes nordestinos. Bol. Tec. DNOCS, Fortaleza 39: 21-32.

ZANATA, L.H. (1999). Heterogeneidade ambiental no reservatório de Salto Grande (Americana- SP) com ênfase na distribuição das populações de Cladocera. Dissertação (Mestrado). CRHEA/ EESC/ USP. São Carlos. 218p.

ZARET, T.M.; PAINE, R.T. (1973). Species introduction in a tropical lake. Science 182: 449-455. 